Carlos Eduardo Silva Carneiro Filho

\title{
Gianni Ratto: Artesão do Teatro
}

Dissertação apresentada no departamento de Artes Cênicas da Escola de Comunicação e Artes da USP, como exigência parcial para a obtenção do título de mestre em Artes.

Orientador: Prof. Dr. Cyro Del Nero

Universidade de São Paulo

Escola de Comunicação e Artes

Curso de Artes Cênicas - 2007 
Carlos Eduardo Silva Carneiro Filho

\section{Gianni Ratto: Artesão do Teatro}

Dissertação apresentada no departamento de Artes Cênicas da Escola de Comunicação e Artes da USP, como exigência parcial para a obtenção do título de mestre em Artes.

Orientador: Prof. Dr. Cyro Del Nero

Universidade de São Paulo

Escola de Comunicação e Artes

Curso de Artes Cênicas - 2007 
PÁGINA PARA ASSINATURAS DA BANCA

presidente 
DEDICATÓRIA

Para Hamilton Saraiva e Gianni Ratto (in Memorian) 


\section{AGRADECIMENTOS}

Ao meu orientador, Prof. Dr. Cyro Del Nero, pela generosidade de acolher-me como seu orientando, e pelos inúmeros ensinamentos de vida, que a convivência do mestrado me possibilitou.

Ao mestre Clóvis Garcia pelos ensinamentos durante todo o mestrado e pela constante disposição em querer ajudar no aperfeiçoamento da pesquisa.

A Anna Lucia Vacchiano, grande amiga que me possibilitou o contato com pessoas fundamentais para a elaboração desse trabalho.

A Cândida Palladino que me incentivou e colaborou com a revisão de parte dessa dissertação.

A amiga Vaner Maria Birolli Ratto que abriu generosamente o acervo de Gianni Ratto para minhas pesquisas.

A minha irmã Márcia Regina de Godoy, que me incentivou e colaborou com a revisão e correção do texto.

Ao amigo Carlos Gouveia pelo apoio e transcrição para o inglês do resumo.

Ao amigo Marcos Caruso que me possibilitou o primeiro contato com Gianni Ratto.

Aos meus amigos Gandia Silva, Cláudia Carvalho, Claudia Marafeli, Roseli Martinelli,

Elcio Paiva, Emílio Fontana, Alessandra Medeiros, Elias Palmo, Vinicius Dias, Anderson Franco e Maria Cristina Nogueirol.

Por fim, e por isso mais importante, a minha mãe, Maria Aparecida de Godoy, e a minha irmã Ana Amélia de Godoy, pela compreensão, apoio e paciência durante todo o processo de pesquisa e elaboração da dissertação.

Aos meus anjos da guarda. A todos os Santos. A Deus. 


\section{Resumo}

A trajetória do diretor, cenógrafo, iluminador, figurinista e professor de teatro Gianni Ratto é abordada nesse trabalho. Sua vida pessoal e profissional, a partir de seu nascimento na Itália até sua chegada e permanência no Brasil. Sua forma de trabalho como diretor. A dissertação objetiva também mostrar a preocupação de Gianni Ratto com a condução do espetáculo através de um trinômio fundamental para sua qualidade estrutural: texto/ator/diretor. A comprovação de sua forma de trabalho, teve por base o registro de entrevistas realizadas com ele, e com pessoas que com ele conviveram e trabalharam, demonstrando sua forma de direção, a partir do convite para dirigir o Teatro Popular de Arte, nos anos 50. Mostra também a importância de Gianni Ratto para o teatro brasileiro, e a preocupação com a valorização de seus autores e atores. 


\begin{abstract}
The trajectory of theater director, scenographer, lighting designer, costume designer and teacher Gianni Ratto is analyzed in this paper. His personal and professional life, from his birth in Italy to his arrival and permanent residence in Brazil. His work method as a director. The objective dissertation also shows Gianni Ratto's concern about the direction of the theatrical performance through a fundamental trinomial for its structural quality: text/actor/director. The corroboration of his work method was based on interviews done with him, and with people who had social and professional contact with him, thus demonstrating his direction method, since the invitation to direct the Popular Theater of Art, in the 1950's. It also shows the importance of Gianni Ratto for the Brazilian theater, and his concern with valuing its authors and actors.
\end{abstract}




\section{Introdução}

De Malas Prontas

\section{Capítulo I}

Piccola Milano

Piccolo

Alla Scala - Um importante degrau

\section{Capítulo II}

Milano-São Paulo (Terra Brasilis Descortinada) 29

São Paulo - Palco Italiano $\quad 29$

Abre-se a Cortina 31

O Número da Criação - O Teatro dos Sete 38

A Cena se Abre: O Teatro Novo 49

La Strada - O Caminho se Faz ao Andar 58

\section{Capítulo III}

Quatro Formas de Amar (O Amor em Quatro Tempos)

O Canto da Cotovia: O amor pela pátria (ou pela religião) 66

$\mathrm{O}$ autor

A história

O texto e a montagem

A Moratória : O Amor pela Terra (ou pela Tradição) 79

O autor

A história 
O Mambembe: O Amor pela Profissão 92

$\begin{array}{ll}\text { O autor } & 92\end{array}$

A história $\quad 94$

$\begin{array}{ll}\mathrm{O} \text { texto e a montagem } & 97\end{array}$

O Amor pela Ética: Gianni Ratto 104

\section{Capítulo IV - Conclusão}

Il Maestro (A Regência do Espetáculo)

A Contribuição do Diretor Estrangeiro ao Teatro Brasileiro

(texto inédito de Gianni Ratto)

Bibliografia

Anexos

Entrevista com Sérgio Britto

Entrevista com Fernanda Montenegro

Entrevista com Bárbara Heliodora

Entrevista com Aimar Labaki

Entrevista com Maria Della Costa

Páginas do programa original de O Canto da Cotovia

Páginas da Revista do MASP - Departamento de Teatro

Páginas do programa original de Eurydice

OBS - Encontra-se na contra-capa final 2 CDs contendo a gravação original do espetáculo O MAMBEMBE, de Arthur Azevedo, encenado pelo Teatro dos Sete, em 1959. 


\section{Introdução}

DE MALAS PRONTAS

A presente dissertação objetiva a análise e acompanhamento de todo o trabalho do profissional de teatro, e do homem, Gianni Ratto, dando maior ênfase a sua atuação como diretor/encenador que às ocupações nas quais ele é mais conhecido no teatro, quais sejam cenógrafo e iluminador. Não obstante, é de suma importância mostrar que a sua atuação como diretor de forma alguma prescinde da observação por parte dele, e dos atores, da criação do cenário, figurinos e iluminação do espetáculo, conquanto são inerentes a todo o processo.

Essa pesquisa deseja contribuir para o resgate de uma personalidade de tamanha importância que é Gianni Ratto, colocando em cena não apenas o grande cenógrafo e iluminador, mas também, e principalmente o diretor de espetáculo, e de ator, preocupado com aquilo levantado e defendido por Richard Wagner, denominado obra de arte total (teatro total). Dessa forma, pretende-se documentar a importância de seu trabalho para a evolução do teatro nacional, a partir dos anos 50, e sua contribuição na formação de grandes atores desse país.

Cabe destacar sua importância como diretor, como também na criação, com Giorgio Strehler e Paolo Grassi, do Piccolo Teatro di Milano, onde atuava especificamente como cenógrafo, porém não deixando de influenciar no resultado final da criação dos espetáculos e na observância do trabalho dos atores, para uma aplicação maior, e efetiva, quando decidisse dirigir um espetáculo, o que aconteceu apenas com sua vinda para o Brasil.

Este trabalho levanta também questões quanto à importância da conjunção do cenário, do figurino e da iluminação na compreensão, por parte do ator, na criação de sua personagem e no resultado final do espetáculo. Até que ponto o conhecimento do andamento da criação dessas áreas permite influenciar a interpretação e no que acarreta para o crescimento do ator? Até que ponto o conhecimento do texto de forma mais aprofundada pelo elenco contribui também para um resultado mais harmônico e denso? É sabido que nos dias de hoje, talvez levados pela urgência de resultados, são poucos os 
profissionais que têm conhecimento de seu figurino, cenário e iluminação, durante o processo de ensaio, e até mesmo o estudo mais detalhado da dramaturgia apresentada.

Tendo trabalhado durante sete anos como cenógrafo no Piccolo Teatro di Milano, além do Teatro Alla Scala, Gianni Ratto, conforme suas próprias palavras, teve a chance de aprofundar sua capacidade crítica em relação ao espetáculo, trabalhando de forma responsável e profunda com diretores e regentes de grande categoria. $\mathrm{O}$ ponto referente ao trabalho junto a grandes regentes e compositores, como no caso de Stravinsky, possibilitou a ele uma maneira mais apurada de observação do espetáculo pois, segundo suas próprias palavaras “o espetáculo teatral deve ser levado como um regente leva uma orquestra, o texto teatral é a música que os atores devem conduzir como conduzem os concertistas numa ópera".

O caminho percorrido pelo diretor, cenógrafo, figurinista e iluminador Gianni Ratto é sobremaneira extenso e muito rico. Para tanto, foi necessário também apoiar a pesquisa em diversos livros teóricos que corroboraram toda a sua visão de direção, e sua cultura, aplicadas na arte de representação.

O trabalho está dividido em quatro capítulos, quais sejam:

Capítulo I, denominado Piccola Milano. Neste capítulo é mostrada a trajetória de Gianni Ratto a partir de seu nascimento em Milão, sua juventude, o início de sua carreira profissional, como também sua saída do Piccolo Teatro di Milano e do Teatro Alla Scala para o trabalho como diretor com Maria Della Costa e Sandro Polônio, num país por ele desconhecido, o Brasil. Nele é apresentado um pouco dos trabalhos realizados pelo diretor antes de sua chegada ao Brasil. Sua atuação junto ao Piccolo Teatro di Milano do qual foi um dos fundadores, juntamente com Giorgio Strehler e Paolo Grassi, bem como os trabalhos realizados para o Teatro Alla Scala.

O capítulo II, denominado Milano-São Paulo retrata o panorama teatral na cidade de São Paulo no início dos anos 50, época da chegada de Gianni ao Brasil. 
Nessa trajetória é traçado o panorama do teatro paulista na referida década, ainda dominado pelo TBC (Teatro Brasileiro de Comédia), que havia sido criado por outro italiano, o empresário Franco Zampari, e que levou diversos artistas a procurarem apoio de diretores estrangeiros, na sua maioria italianos, para direção de espetáculos de novas companhias teatrais ou mesmo das que já existiam.

Conforme relato do próprio Gianni Ratto, apesar de já possuir uma sólida posição artística na Europa como cenógrafo, e já se projetando como iluminador e figurinista, ele sentia necessidade de algo que estimulasse mais sua criatividade, como a direção de espetáculos, coisa que era muito difícil ao lado de Strehler, que não abria mão dessa função no Piccolo. Em virtude disso, aceitou prontamente a aventura de vir para o Brasil com Maria Della Costa e Sandro Polônio com a finalidade de dirigir sua nova companhia, que teria como primeira encenação O Canto da Cotovia, de Jean Anouilh.

No capítulo III - Quatro Formas de Amar - é analisada sua trajetória como diretor/encenador, não desprezando, todavia, seu importantíssimo trabalho conjunto de cenografia, iluminação e figurinos. Para tanto foram escolhidos três espetáculos que tiveram grande significado para sua carreira e para o teatro brasileiro.

Estes espetáculos, devido as suas diferentes estruturas dramáticas, mostram o panorama da atuação de Gianni Ratto como diretor. Dessa forma, são abordados O Canto da Cotovia, que foi o primeiro espetáculo por ele dirigido e que recebeu praticamente todos os prêmios da época; A Moratória, que lançou o dramaturgo brasileiro Jorge Andrade, servindo de ponto de referência para um novo tipo de dramaturgia, valorizando o autor nacional; e por fim O Mambembe, espetáculo cômico/musical que teve a função de trazer novamente ao lugar de destaque que merecia, um dos maiores dramaturgos do país, Arthur Azevedo, que tem em sua obra a preocupação da valorização da cultura nacional.

Diferentemente de outros diretores, principalmente contemporâneos, que necessitam imprimir em seus espetáculos uma "linguagem", um "método" de trabalho, a preocupação maior de Gianni Ratto, como ele mesmo dizia, era a de fazer um bom espetáculo, honesto e digno, que valorizasse os atores, engrandecendo suas atuações 
como forma de atingir o público para que guardasse consigo um pouco da experiência única pela qual passou, ou até mesmo cumprir a função de modificar, de alguma forma, aquele que a presenciou, e não "deletá-la" de sua memória como um produto descartável desses novos tempos.

No último capítulo, nominado Il Maestro: A Regência do Espetáculo, é concluído o presente trabalho com uma análise mais pormenorizada da forma de trabalho de Gianni Ratto, a base da criação do espetáculo, centrada na construção da personagem pelo ator, sem prescindir do conhecimento da cenografia, iluminação, figurino e música, contribuindo, assim, para uma maior estruturação dos trabalhos vocais e corporais do ator e sua identificação com o espectador. "Tudo sempre irá depender de quem se aventura pelas terras movediças, traiçoeiras e fascinantes, ingratas e gratificantes daquilo que costumamos chamar Teatro" 1 .

Cabe salientar que Gianni Ratto levanta, dentro dessa perspectiva, a importância do texto para a construção do espetáculo. Conforme suas próprias palavras: "O critério da integração das artes está ligado a um processo de trabalho cuja espinha dorsal é a poética e a temática do texto"2.

Gianni Ratto, modestamente, tinha como poucos uma visão muito clara do papel do teatro e do espetáculo. Sabia da sua importância como congregador de todas as artes para que esse trabalho pudesse refletir no público e, dessa forma, ser sempre único, apesar da repetição das apresentações. "A música, a pintura, a arquitetura, o artesanato, a luz, os adereços, fornecem um instrumental que o espetáculo recebe e manipula para um resultado irrepetivel e único "3, dizia ele.

Quem conheceu Gianni Ratto sabe a grande inteligência, o grande coração, a grande pessoa que se escondia atrás de uma, também, grande modéstia. São muitas as frases e conselhos, suas histórias, visão do mundo, e a poesia existentes em cada gesto e olhar. Também nesse capítulo conclusivo, foram compiladas algumas dessas

\footnotetext{
${ }^{1}$ Ratto, Gianni - Hipocritando . RJ, Bem-te-vi Produções Literárias, 2004. pág.21

${ }^{2}$ Ratto, Gianni - A Mochila do Mascate, SP, Editora HUCITEC, 1996, pág. 155.

${ }^{3}$ Idem, pág 154.
} 
informações, e opiniões, obtidas através de depoimentos pessoais, e, outras, tiradas da memória de pessoas queridas que com ele conviveram.

O objetivo desse trabalho é conseguir, ao menos, divulgar, mesmo que de forma simples, um pouco de toda a sabedoria desse grande homem, e profissional de teatro. E que todos que ouvirem ou, melhor, lerem suas palavras façam chegar até ele sua satisfação, e reconhecimento, através do som que leva até os deuses do teatro, onde agora ele se encontra, o aplauso por sua obra e seus ensinamentos. Boa Viagem! 


\section{CAPÍTULO I \\ PICCOLA MILANO}

Itália, 1916. A Europa sente o trauma de uma guerra mundial em andamento, iniciada praticamente dois anos antes. Não obstante, a Itália membro da Tríplice Aliança ${ }^{4}$, mantêm-se, até então, neutra no conflito. Todavia, a situação da Itália, nesse acordo era instável, uma vez que os italianos em sua maioria, eram desfavoráveis ao estabelecimento de um acordo com o império Austro-Húngaro, antigo inimigo de sua unificação. Dessa feita, exatamente no dia 27 de agosto desse ano, ela declara guerra à Alemanha passando a fazer parte da Tríplice Entente ${ }^{5}$, tendo como justificativa a de que a Tríplice Aliança, da qual fazia parte, era um acordo de defesa, enquanto que na ocasião da deflagração da guerra foram os impérios germânicos os ofensores. Nesse mesmo dia, em Milão, nasce Giovanni Ratto, que será mais conhecido por Gianni Ratto, mas será Gênova a cidade de sua infância, a cidade de sua aliança.

O vírus do teatro, desde cedo passou para ele, quando já se encontrava no internato, aos oito anos de idade, no Colégio de Nervi, bairro marítimo de Gênova. O estabelecimento de ensino era bem conceituado e regido por padres somascos ${ }^{6}$. No colégio havia um teatro com capacidade para duzentas pessoas, que cumpria diversas funções, oferecendo desde aulas de boas maneiras e palestras sobre diversos assuntos até audições de música de seus alunos e espetáculos de variedades. O responsável pelo teatro e suas apresentações - e pela "contaminação virótica da arte teatral - era o padre Frumento, que dirigia ensaios e estabelecia a programação. Porém ele mesmo, talvez por se entusiasmar com a arte teatral e esbanjar verbas escolares na cenografia de seus espetáculos, acabou por ser transferido.

\footnotetext{
${ }^{4}$ Acordo assinado em 1882, do qual faziam parte a Alemanha, a Áustria-Hungria com o objetivo de enfrentar o expansionismo francês na Europa. Mais tarde, é incorporado a ela o Império Otomano por sua aliança com a Alemanha e por suas rivalidades com a Rússia, bem como a Bulgária, que tinha grandes interesses nos Bálcãs, tendo se aliado também à Alemanha.

${ }^{5}$ Acordo com base na Entente Cordiale (nome dado às boas relações existentes entre a França e a Inglaterra no início do século XX), formada em 1904 pelo Reino Unido e França para opor-se ao expansionismo germânico que, com a adesão da Rússia em 1907, recebe esse nome. Durante a guerra, outras 24 nações a ela se incorporam formando uma ampla coalizão denominada Aliados.

${ }^{6}$ Os religiosos somascos, a exemplo de São Jerônimo Emiliani, se dedicam de modo especial ao serviço dos pobres e da juventude, cuidando particularmente dos órfãos e dos marginalizados. Por essa razão, nos diferentes países em que vivem e trabalham, assumem múltiplas tarefas: assistencial, educativa, de prevenção, de promoção humana e cristã, tendo atenção especial para com meninos e jovens.
} 
Gianni Ratto permaneceu no colégio ainda por dois anos, tendo a oportunidade de participar como ator de um espetáculo. Nessa ocasião, um ator convidado (pertencente a um grupo diletante da cidade de La Spezia) que vinha anualmente participar de espetáculos de variedade que o colégio organizava por ocasião de alguma festividade assistiu ao espetáculo e vaticinou seu grande futuro como ator.

Foi nesse mesmo período que as portas da leitura lhe foram abertas, através da poetisa italiana Rossana Zezzos, amiga de sua mãe que, constantemente, lhe enviava livros dando-lhe a satisfação de travar conhecimento com as obras de Charles Dickens, Júlio Verne, Joseph Conrad, Hans Andersen e Irmãos Grimm, entre outros.

Os próximos dois anos seriam passados num colégio em Cherasco, província de Cuneo, na região do Piemonte, local de cultivo de uvas, amoras e trigo. Ao terminar o segundo período do curso ginasial, e já numa fase adolescente onde a figura paterna rondava seus pensamentos e questionamentos, o menino exige de sua mãe freqüentar uma escola de arte, ciente de sua vocação artística pelos desenhos que realizava. Nessa época já estava casada com Leandro Criscuolo, grande pianista que se tornou professor do ensino público e particular. A muito custo, e para evitar indagações sobre o exmarido, sua mãe contraiu empréstimos para realizar a vontade do filho. Porém, aconselhada por um advogado, se viu obrigada a procurar o pai de Gianni e exigir uma quantia em dinheiro que possibilitasse seus estudos. Foi dessa maneira que ele conheceu seu pai, pois o mesmo condicionou a entrega do dinheiro a uma visita do menino a seu escritório para que o conhecesse. Ele já contava com treze anos e passou a freqüentar o Liceu Artístico e, conforme ele mesmo afirmava, desenhava muito mal e considerava-se moderno, defendendo os futuristas e seus compositores, como Balilla Pratella e Russolo, e nas artes plásticas os nomes de Marinetti, Picasso e Balla.

A música sempre teve para ele um importante papel. Além de crescer ouvindo sua mãe dar aulas de música, ainda em Gênova freqüentava com ela inúmeros concertos e, dessa forma, já se tornava partitura constante de sua vida. Sua importância é patente ao dizer:

"A música me envolvia sensorialmente; eu não tinha ainda numa preparação que me permitisse avaliar se a execução estava boa ou 
não, se os equilíbrios tímbricos eram exatos, se os fraseados corretos. Eu me deixava levar intuitivamente por uma beleza que para mim equivalia, naqueles momentos, ao prazer que eu tinha quando rolava num campo de narcisos ou de alfazema até um rio gelado. Amava, sobretudo as mudanças de intensidade sonora, a passagem de um pianíssimo para um crescendo até uma explosão de trompas, tímpanos, cornos e fagotes. Os movimentos dançantes agitavam meu corpo e se por acaso já tivesse ouvido a música, a cantava em voz baixa até o momento em que um "shht"aborrecido fazia-me calar envergonhado. E acontecia um fato curioso: ao mesmo tempo que eu desejava que a obra executada nunca terminasse, ansiava pelo fim da sinfonia ou do poema sinfônico para poder aplaudir freneticamente num orgasmo catártico indispensável para o feliz término de minha noite." 7

Gianni Ratto nunca freqüentou academias de arte, substituídas que foram pelo convívio com artistas plásticos e músicos, graças à influência da família de sua mãe, Maria Ratto, professora de piano, canto, e musicista. Seu trabalho com cenografia iniciou-se quase que por acaso. Sem saber nada de teatro, até mesmo a estrutura técnica de um palco, em 1932 entrou em um concurso de cenografia em Gênova, o qual acabou ganhando. Aliás, vale lembrar que um de seus primeiros contatos com a cenografia se deu através do conhecimento de um dos maiores mestres de teatro do mundo, Gordon Craig. Sua filha, de quem se tornou amigo, fazia aulas de canto com Maria Ratto, mãe de Gianni, em Gênova, o que lhe possibilitou o contato com este grande homem de teatro, despertando no jovem uma série de descobertas que se concretizariam em sua definição profissional.

Ainda antes da Segunda Guerra, estudando Artes Plásticas no Liceu Artístico de Gênova, Gianni necessitava de um emprego para ajudar sua mãe e, assim, não depender mais da mesada de seu pai. Foi dessa maneira que colocou um anúncio no Secolo XIX, o diário mais lido de Gênova, e acabou sendo convidado a trabalhar com o arquiteto Mario Labò, homem que teria grande importância na vida e carreira de Gianni Ratto. Na

\footnotetext{
${ }^{7}$ RATTO, Gianni. “A Mochila do Mascate” p 82/83 - Ed. Hucitec - São Paulo - 1996.
} 
realidade, ele, conforme suas próprias palavras, "tinha sido para mim o pai que eu não tivera". Gianni tornara-se amigo do filho de Mario, Giorgio, que tinha mais ou menos a sua idade, recebendo de Mario o mesmo carinho e atenção que dispensava ao filho, o qual acabou morrendo em virtude da guerra.

Gianni Ratto, muitas vezes, se referia ao arquiteto, nas conversas realizadas para a elaboração desse trabalho, com um imenso carinho e admiração. A importância dessa figura em sua carreira, e na sua vida como homem, pode ser atestada nesse depoimento:

“...,quando eu estava cursando cinema e ele ia a Roma, sempre me procurava levando-me para almoçar e, quando voltava para Gênova, depois de avisar Enrica, sua mulher, da hora da chegada, no cais da estação, ainda me dava um dinheirinho. Mas não era por isso que eu o amava; ele sabia ser severo quando necessário e, aparentemente, nunca tinha me ensinado algo ostensivamente: acho que ele me assumira, passando para mim, de forma indireta, noções e conhecimentos que nenhuma aula teria conseguido transmitir. Quando, por ter sido aceito no Centro Sperimentale di Cinematografia, eu tive de ir a Roma, me dei conta de sua tristeza; quando ainda na Sardenha, quis participar de um concurso universitário de cenografia, mandei-lhe o projeto e ele, com a colaboração de meu amigo Nino $^{8}$, realizou a maquete. Emprestavame livros, analisava meus quadros, sem piedade mas bondosamente e com um senso crítico profundo e sereno." "9

Seu primeiro contato com cenografia se deu por ocasião de uma exposição de Cenografia, organizada por Bragaglia $^{10}$, que estava viajando pelo mundo e que, em 1932, apresentou-se em Gênova. Era uma exposição revolucionária em relação à

\footnotetext{
${ }^{8}$ Nino Bonamici - amigo de Gianni da época do Liceu Artístico.

${ }^{9}$ RATTO, Gianni - "A Mochila do Mascate", p. 155. - Editora Hucitec. São Paulo - 1996.

${ }^{10}$ Anton Giulio Bragaglia (1890-1960). Diretor e jornalista. Um dos seguidores e criadores da estética Futurista, tendo desenvolvido dentro da fotografia a técnica da fotodinâmica. Criador do Teatro dos Independentes, ponto de elaboração e referência para a pesquisa do teatro italiano. Montou espetáculos de autores como Jarry, Apollinaire, Laforgue, Strindberg, O'Neill, Brecht, Marinetti, Pirandello, Svevo e Rosso di San Secondo. Posteriormente, é chamado a dirigir o Teatro delle Arti até 1943, cuja atividade é relacionada a "Galeria di Roma", criada em 1930.
} 
cenografia tradicional. Convidaram alunos de sua escola que tivessem interesse em participar também da exposição na cidade. Gianni se interessou em participar e rapidamente se informou melhor sobre o assunto, estudou algumas peças e escolheu fazer um cenário para As Nuvens, de Aristófanes.

"Ter realizado meu projeto, que eu mesmo executei com um velho serrote, cabos de vassouras como colunas, e caixotes de fruta pedidos ao quitandeiro, me entusiasmou. Giúlio Pacúvio, um jovem diretor me disse: você tem que colocar uma luz laranja, a comédia grega é dourada! Eu não entendi bem, mas fui atrás dele num grupo de amadores que ele estava dirigindo. Fiz de tudo: saí na rua procurando coisas e fiquei nos bastidores me apaixonando pela jovem atriz que fazia o papel principal. O teatro sempre começa com um ato de amor: dionisíaco ou técnico" $"$.

Dessa forma, teve início seu trabalho na área teatral. A partir daí, entrou em contato com o teatro universitário da cidade, começou a fazer cenários e maquetes participando também de diversos concursos sendo premiado, o que the possibilitou viajar e despertar também o interesse por cinema, levando-o até a escrever alguns roteiros.

A partir de sua iniciação cenográfica, foi estudar cinema em Roma, sendo admitido no Centro Sperimentale de Cinematografia di Roma graças ao segundo lugar que ganhou em um concurso de argumentos para filmes de curta metragem, em dezesseis milímetros, promovido pela revista CINEMA. Após seis meses, em função de um exercício de filmagem sobre um argumento baseado na confissão de Raskolnikov a Sônia, no romance Crime e Castigo, de Dostoievsky, ganhou uma bolsa de estudos.

A idéia do Centro era criar novos quadros de técnicos, atores, cenógrafos, diretores, montadores etc. No período em que ali estudava, o Centro funcionava precariamente em algumas salas e subsolos de um subúrbio romano. As aulas começavam às oito horas da manhã e, quando havia exercícios de filmagem,

\footnotetext{
${ }^{11}$ Entrevista concedida a Maria de Lourdes Rabetti Giannella - novembro/1982.
} 
continuavam até o dia seguinte sem parar, e as atividades abrangiam todos os aspectos imagináveis de uma produção. "Ao mesmo tempo em que éramos, eventualmente diretores, também montávamos os módulos cenográficos, colando por cima papel ou pintando etc. Era um trabalho entusiasmante e exaustivo. ${ }^{12, "}$

Quanto à participação efetiva no cinema profissional, só em casos muito excepcionais era admitida a saída do aluno do Centro Sperimentale, pois muitas vezes ele não voltava mais. Alguns casos foram, excepcionalmente, autorizados como o da atriz Alida Valli, mas a norma era que os alunos completassem o curso antes de atuarem profissionalmente. Dessa forma, Gianni Ratto iniciou curso de direção, infelizmente interrompido em virtude do início da Segunda Grande Guerra.

Desejoso de sair de uma rotina mesquinha e fugindo de um meio medíocre onde, segundo ele, não havia a mínima possibilidade de sobrevivência interior, foi admitido, em 1941, na Escola para Oficiais de Fano ${ }^{13}$. Ali conhece, através de Giannino Galloni, aquele que viria a ser seu grande amigo, Paolo Grassi, com quem iria fundar juntamente com Giorgio Strehler, o Piccolo Teatro di Milano.

Foi a partir da amizade com Paolo que Gianni desenvolveu seus contatos teatrais, pois o amigo, desde a Universidade mantinha contato com diversos artistas escrevendo todos os dias mais de vinte cartões para todas as cidades onde houvesse pessoas que lidassem com a área artística. Suas conversas versavam sobre a falência do teatro profissional e o império do "divismo" e sobre o sonho de, ao final da guerra, criarem uma dramaturgia própria e autêntica, onde o público seria participante e não apenas espectador.

Graças às boas amizades cultivadas por Paolo dentro do exército, a dupla conseguiu do Comando Superior autorização para realizar espetáculo musical satírico no Teatro della Fortuna, uma das grandes construções setecentistas do arquiteto Bibiena, recebendo ainda permissão para irem até Milão alugar material para, na volta, realizar os ensaios do espetáculo. Dessa forma, dispensado das tarefas militares, Gianni se ocupou da cenografia, tornando-se o alter ego de seu amigo Paolo Grassi,

\footnotetext{
${ }^{12}$ Id.

${ }^{13}$ Comuna italiana da região dos Marche, província de Pesaro e Urbino, no Adriático.
} 
responsável pela realização do espetáculo, o qual teve sucesso estrondoso entre os alunos e oficiais superiores, resultando no recebimento de suas patentes. Segundo ele mesmo conta, o período da Guerra lhe forneceu um aprendizado de vida muito rico ao convier com o povo grego (pois foi destacado para permanecer uma época na Grécia), modestos camponeses agredidos pelas milícias fascistas e hitleristas, aproximando-o de uma compreensão humana até então somente intuída por ele.

Terminada a Guerra, Gianni permaneceu ainda alguns meses em Gênova trabalhando como desenhista com o arquiteto Mario Labò e mantendo contato com seus amigos que trabalhavam em teatro. Na procura por trabalho ele se aventura em Roma, sem sucesso, terminando por estabelecer-se em Milão, onde viviam alguns de seus amigos da época da Escola de Guerra. Um dos que mais o ajudou nesse início de carreira, com a Europa tentando superar o trauma de uma Guerra, foi Gianino Galloni. O amigo vivia com a esposa num elegante escritório de seu sogro no centro de Milão, onde acolheu Gianni. Local de onde se lançavam em empreitadas de trabalho. Apesar da elegância do estabelecimento, muitas vezes não tinham o que comer e dormiam alternadamente numa poltrona e quatro cadeiras.

Apesar de tudo, Gianni Ratto conseguiu, nessa época, trabalhar com inúmeros diretores de categoria, como Adolfo Celi para o qual fez os cenários do espetáculo musical A Bela Helena, de Offenbach, tendo mais tarde também trabalhado para a Companhia Vittorio de Sica, onde realizou a cenografia para Nick Bar, de William Saroyan. Outros trabalhos vieram, como as parcerias com Maner Lualdi, no Teatro Excelsior, numa temporada dedicada exclusivamente a autores italianos; com Vito Pandolfi, para quem projetou o cenário de A Longa Noite Sem Lua de John Steinbeck; com Orazio Costa, num festival dedicado ao tragediógrafo Vittorio Alfieri; com Guido Salvini, para quem projetou e iluminou a cenografia para Encontro em Saint Lis, de Jean Anouilh, entre outros. O trabalho crescia a cada dia, fazendo com que o nosso artista chegasse a projetar sete cenários num mesmo dia e, algumas vezes, tendo até a ousadia de encomendar que fossem executados telões de espetáculos de revista por telefone. 


\section{Piccolo}

Nesse ínterim, a amizade entre Gianni Ratto, Paolo Grassi e Giorgio Strehler ainda se mantinha forte, acalentando, os três, o sonho de formar um grupo de teatro que pudesse realmente expressar toda sua criatividade. Um teatro que se preocupasse mais com o povo do que com um público de poder aquisitivo. Basicamente um teatro de idéias, sem as convenções do teatro tradicional, que permitisse romper com os padrões teatrais estabelecidos e que estivesse sempre focado em produzir espetáculos profissionais de categoria.

A preocupação de Giorgio era a de conseguir elencos de primeira, independente do papel a ser desempenhado. Dessa forma, surgiu o "Grupo do Strehler". A esse respeito disse Gianni:

"O grupo foi a conseqüência de um inter-relacionamento entre gente jovem de teatro, que aspirava a uma ruptura definitiva dos processos das companhias dramáticas profissionais ligadas ao obsoleto conceito do "mattatore" ( o grande ator que arrasava com a sua interpretação excepcional, ou não, qualquer texto ou qualquer espetáculo). Justamente com Strehler, Grassi, Jacobbi, Celi, Salvini, Orazio Costa, Giannini, Ivo Chiesa e um grande número de outros jovens talentos, iam se definindo novos conceitos que, pela própria estrutura do teatro vigente, só encontravam vazão em espetáculos esporádicos para os quais atores donos de companhias ("capocômicos" e empresários) interessados nos movimentos de após-guerra, abriam os espaços do palco e seus magros orçamentos. $E$ importante não esquecer que para tanto dispúnhamos contrariando conceitos que nós achávamos básicos - de sete ou oito dias - para ensaiar e estrear, para projetar e executar cenários, figurinos e iluminação." 14

\footnotetext{
${ }^{14}$ Depoimento de Gianni Ratto ao autor da dissertação, outubro de 2005.
} 
Gianni se preocupava com a possibilidade de estabelecer um padrão visual que rompesse com os hábitos das companhias itinerantes. Enquanto Paolo Grassi, incansavelmente continuava a escrever seus cartões e cartas para pessoas influentes, empresários e banqueiros, entre outros, na esperança de conseguir subsídio para concretização desse sonho de um espaço próprio, porém sem sucesso.

Foi através do prefeito de Milão, à época, Antonio Greppi, que o sonho passou a ser realidade. Isso se deu em virtude de seu filho - assassinado pelos alemães -, que havia lutado na guerra, ter sido um ativista antifascista e, como eles. Dessa forma, viu no sonho dos jovens, com o mesmo passado de guerra, a concretização do sonho de seu filho, covardemente morto por uma guerra que apenas havia trazido destruição.

Dessa feita, Greppi apresentou aos rapazes um espaço na Via Rovello, próximo ao Castelo Sforzesco, no coração de Milão, onde havia funcionado um pequeno cinema que durante a Guerra tinha se tornado quartel de milícias fascistas. A visita ao local foi comentada por Strehler:

"Uma platéia abandonada com poltronas desconjuntadas, um palco vazio, o pano de boca semilevantado. De repente, enquanto olhávamos em volta, um raio de sol entrou por uma clarabóia indo se colocar num canto do palco. Foi como se por algum prodígio um projetor e sua lâmina de luz quisessem indicar o palco, aquele palco. Um convite, uma provocação?",15

A partir desse encontro, foram desenvolvidas estratégias que possibilitassem subvenções para a ocupação e transformação do espaço no tão sonhado teatro do grupo. O setor de construções civis da municipalidade assumiu o encargo das reformas necessárias, o que possibilitou à cidade a criação de um organismo cultural à disposição dos cidadãos: o Piccolo Teatro di Milano. O nome do local foi escolhido em razão da peça Ralé de Máximo Gorki, selecionada para inaugurar o espaço e, conseqüentemente, foi uma homenagem ao famoso teatro de Moscou Malij Teatr, ou seja, Pequeno Teatro: "Piccolo Teatro".

\footnotetext{
${ }^{15}$ RATTO, Gianni. “A Mochila do Mascate”, p. 254.Ed. Hucitec. São Paulo. 1996.
} 
Gianni Ratto foi o responsável pela reforma do espaço, chegando até mesmo a detalhar as luzes das mesas de maquiagem dos camarins, compostas de braços pantográficos de madeira leve, articulados e giratórios.

Apesar da cessão do espaço pela prefeitura de Milão, o dinheiro era pouco para a transformação da casa de espetáculos, mesmo sendo ela um piccolo teatro. Dessa forma os materiais foram comprados a prazo, além de os técnicos aceitarem trabalhar em regime de contenção de despesas. O pouco dinheiro, que vez ou outra aparecia, era fraternalmente dividido entre todos. Enquanto isso, Strehler, Grassi e Gianni, continuavam a exercer atividades paralelas com o objetivo de conseguirem apoio à nova empreitada e dinheiro para a concretização do projeto, muito criticado pois muitos não gostavam de Paolo Grassi, achavam Strehler apenas um bom iluminador e consideravam Gianni um novato, o que não dava muito crédito a idéia de teatro estável por eles defendida. Não obstante, conseguiram criar uma grande torcida ao redor de seu projeto, com o apoio das pessoas mais esclarecidas e de uma geração mais nova de intérpretes, os quais também vislumbravam a possibilidade de um trabalho permanente e qualitativo.

A experiência como cenógrafo, e conseqüentemente seu crescente sucesso, já se afirmava anteriormente à criação do Piccolo. Gianni já havia concebido cenários para espetáculos como Uma Mulher Livre, de Salacrou, Winterset, de Maxwell Anderson, Teresa Raquin, de Emile Zola, Calígula, de Albert Camus, Pick-up Girl, de Mary Shelley, Desejo Sob Os Olmos e O Luto Cai Bem a Eletra, ambas de Eugene O'Neill, para o Teatro Odeon de Milão, sem considerar outros trabalhos de menor importância.

Todavia, o cenário para Ralé, que iria inaugurar o Piccolo, parecia uma tarefa difícil, uma vez que o palco era extremamente pequeno, de uma profundidade mínima e com uma altura de nove metros, porém muito provocante para o cenógrafo que adorava desafios. $\mathrm{Na}$ área, que não chegava a quarenta metros quadrados, deveriam ser colocados múltiplos espaços, nos quais se desenrolariam as cenas da peça, onde também eram previstas também áreas de circulação para as personagens. $\mathrm{O}$ cenário planejado partiu de uma intuição não decorativa do artista levando-o a estruturar a planta semicircular de um poço úmido e insalubre, tendo ao fundo beliches de favela que eram alcançados por uma periclitante escada de madeira que levava a uma altura de quase três 
metros até o nível da rua, onde figuravam, a níveis mais altos, duas minúsculas janelas através das quais filtrava uma luz "tísica e cinzenta".

A maior preocupação de Strehler, ao ver o cenário realizado, era quanto à solidez da escada projetada por Gianni, uma vez que ela realmente dava a aparência de extrema fragilidade, feita que era com pedaços de madeira. Em resposta, Gianni subiu e desceu várias vezes a escada, se debruçando em seu corrimão e, ainda, algumas vezes, pulando de dois em dois degraus, a fim de demonstrar sua segurança.

A referida "intuição decorativa", aliada à prática do trabalho junto a diversos cenógrafos, possibilitou o crescimento e a consolidação do nome Gianni Ratto como um dos maiores de sua área. Foi através de seu trabalho na cenografia que ele pôde aprofundar sua capacidade crítica com relação ao espetáculo que, comprovadamente e conforme suas próprias palavras, é algo fundamental em teatro, e possibilitou, posteriormente, seu trabalho como diretor de teatro.

\section{Alla Scala - Um importante degrau.}

O verdadeiro reconhecimento profissional, dentro do mundo teatral de Milão, e conseqüentemente da Itália, se deu quando o superintendente do Teatro Alla Scala, Antonio Ghiringhelli, convidou Gianni Ratto e Giorgio Strehler para, respectivamente, projetar os cenários e figurinos, e dirigir a ópera La Traviata, de Giuseppe Verdi.

Ghiringhelli era um conhecido industrial milanês que corajosamente assumiu o encargo de reconstruir o edifício do teatro que estava semidestruído em função de inúmeros bombardeios ocorridos durante a Segunda Guerra Mundial.

O grande desafio de Gianni surgiu na hora de projetar o cenário para a ópera, num palco completamente diferente daqueles que estava habituado, que até então eram semelhantes, em tamanho, ao do Piccolo Teatro, com sete metros de boca de cena por seis de profundidade. O Teatro Alla Scala, como ainda é até hoje, possui uma boca de cena de dezesseis metros por dez de altura, e vinte e cinco metros de profundidade, sem contar a medida da altura para o urdimento. Para encarar a empreitada, leu tudo que 
podia sobre A Dama das Camélias, tema da ópera para a qual faria o cenário, consultando livros de arquitetura, de mobiliário, decoração e linguagem de moda da época em que se passava a ação, até chegar à conclusão de que seus cenários e figurinos deveriam ter "um sabor de gravura colorida". A técnica de pintura utilizada foi a aquarela, técnica essa que ele dominava e que passou a ser sua linguagem artística. Com esse espírito, o cenário resultou em estrondoso sucesso sem, porém, é claro, suscitar celeuma entre diversos críticos, tendo os renovadores aplaudido seu trabalho e os mais conservadores considerado tudo aquilo um verdadeiro "escândalo". Isso pode ser comprovado no início da crítica de Franco Abbiati para o Corriere della Sera: "Três pessoas assassinaram ontem a Traviata: o regente Tullio Serafin, o diretor Giorgio Strehler, e o cenógrafo Gianni Ratto...”. Não obstante, os elogios sufocaram os protestos, resultando num novo convite para o Teatro e possibilitando que Gianni Ratto permanecesse por mais sete anos realizando trabalhos para o Alla Scala, inclusive como seu vice-diretor para montagens cênicas durante dois anos.

O trabalho no Scala possibilitou a Gianni Ratto um acúmulo de experiência jamais imaginado dentro de uma escola teatral. O contato com diretores, regentes, bailarinos, cantores, coreógrafos, nacionais e estrangeiros, serviu-lhe como verdadeiras aulas, sem contar o prazer desfrutado ao assistir aos ensaios dos espetáculos. Artistas como Stravinsky, Arthuro Toscanini, Victor DeSabata, Jean Babilée, Leonor Fini, Romanoff, Dall'Ara, Von Karajan, Maria Callas, entre muitos outros, enriqueceram sua vida profissional. Vale destacar o contato diário com o grande cenógrafo, figurinista e designer russo Nicola Benoit que lhe ensinou que "um grande palco deve ser tratado como a uma mulher orgulhosa e bela, que só se deixa dominar quando percebe que quem a provoca é digno dela."

De qualquer forma, é importante mencionar que também não foi fácil a convivência com tantas estrelas e o mau caráter de alguns artistas, e funcionários, ligados às áreas técnicas. Muitos dos cenógrafos realizadores, aqueles que executavam os desenhos possuíam uma técnica esplêndida aliada a uma ausência total de criatividade provocando assim profundo recalque, deixando-os extremamente frustrados e invejosos. Importante lembrar que eram seis equipes de realização cenotécnica, devido ao tamanho do teatro e o grande número de montagens previstas. No entanto, Gianni 
conseguia, com muita habilidade diplomática, sobreviver naquela selva, fato que lhe possibilitou galgar os degraus profissionais que almejava.

Dessa maneira, Gianni ia construindo sua trajetória como grande cenógrafo, iluminador e figurinista, dentro do teatro italiano, ancorado por trabalhos no "Piccolo" e no "Scala". Todavia a enorme criatividade que possuía, aliada à necessidade de novos desafios, não o deixava satisfeito apenas com essas atividades. Gianni Ratto queria mais. Ele sentia necessidade de ensinar, de reunir todas aquelas experiências de forma que se amalgamassem num único produto, resultado de seu trabalho e experiência. Gianni precisava dirigir um espetáculo. Todavia, apesar do incentivo de inúmeros colegas para lançar-se nessa nova atividade, uma vez que sempre acompanhava os ensaios e discutia artisticamente com eles, Gianni achava que o teatro que ele conhecia, o teatro italiano, estava se tornando um círculo vicioso, sem grandes desafios ou estímulos.

O novo desafio, que o impulsionou para a carreira de diretor, veio num belo dia em que estava trabalhando no Piccolo e foi avisado pelo diretor administrativo do teatro, que uma moça muito bonita, brasileira, acompanhada de seu marido estavam viajando pela Europa a procura de um diretor que se dispusesse a ir para o Brasil inaugurar e dirigir o seu teatro. Sabendo dos anseios de Gianni em viajar e também se aventurar nessa nova área, logo colocou-os em contato com ele. Maria Della Costa e Sandro Polloni já conheciam o sucesso do artista e convidaram-no para esta aventura.

Gianni comenta também que sua ida para o Brasil se dá graças a Ivo Chiesa, que seria o futuro diretor do Teatro Stabile de Gênova:

"Crises de vários gêneros, desde as pessoais às de caráter estético político, discordâncias de caráter político e estético com o teatro em geral - não esquecer que em oito anos fiz tudo que um cenógrafo humanamente poderia ter feito no teatro: teatro dramático para companhias estáveis e itinerantes; festivais nacionais e internacionais; teatro de revista; teatro lírico; exposições internacionais; participação em comissões julgadoras; palestras etc.); crise, como dizia, que implica, inclusive, na necessidade 
imperiosa de aplicar a minha experiência no campo da direção teatral num país onde a inteligência e a capacidade profissional são vendidas a varejo; uma certa involução exaustiva devida ao sucesso e à segurança, faziam com que eu desejasse encontrar um outro campo de trabalho onde o erotismo teatral estivesse ainda em um estado quase virginal" ${ }^{\prime \prime}$.

Gianni estava feliz, queria conhecer lugares novos. O que sabia sobre o Brasil se restringia ao documentário Inferno Verde, filmado por um cineasta italiano na Amazônia, pela leitura de um romance de Machado de Assis e uma breve olhadela numa gramática ítalo-brasileira.

A viagem para esse desconhecido país da América do Sul seria um novo marco em sua carreira, o rompimento com tudo aquilo que já havia construído, toda sua brilhante carreira de cenógrafo e iluminador. Sua vinda para o Brasil também seria de fundamental importância para o teatro brasileiro, um elixir de renovação e de descoberta da própria identidade. Após catorze dias de viagem, o navio chegou ao Rio de Janeiro, onde os passageiros desembarcaram, no cais da praça Mauá, para um descanso de dez horas, após o qual ele continuaria a viagem até o porto de Santos, em São Paulo, seu destino final. Alguma coisa lhe dizia que sua missão artística seria realmente revelada. Desse outro lado do oceano, nesse novo país que se tornaria o seu país, a sua casa.

\footnotetext{
${ }^{16}$ Anotação de entrevista com Gianni Ratto concedida ao autor da dissertação em 2004.
} 


\section{CAPÍTULO II}

\section{MILANO-SÃOPAULO ou TERRA BRASILIS DESCORTINADA}

\section{São Paulo - Palco italiano}

O panorama teatral em São Paulo, no início dos anos 50, era bastante promissor. O público via-se estimulado cada vez mais a comparecer aos espetáculos apresentados por companhias nacionais. O maior destaque, marco divisor do teatro brasileiro, foi o TBC (Teatro Brasileiro de Comédia), que teve início com um grupo amador, criado em 1948 pelo industrial italiano Franco Zampari, que transformou uma pequena garagem no número 311 da Rua Major Diogo, no Bixiga, reduto dos imigrantes italianos, num teatro de 365 lugares, com um palco com bastante profundidade mas pouca altura, e que posteriormente foi melhorado. Os espetáculos de estréia do grupo, em 11 de outubro de 1948, foram A Voz Humana, de Jean Cocteau, e A Mulher do Próximo de Abílio Pereira de Almeida.

A profissionalização do grupo se deu em 1949 pelo fato de Zampari não concordar que um empreendimento como aquele, que possuía uma estrutura profissional com equipe técnica que recebia por seu trabalho, contar com atores amadores, que apesar de amarem o que faziam, ao contrário dos técnicos nada recebiam por sua atuação. É preciso lembrar que a estrutura montada pelo empresário no TBC, através da Sociedade Brasileira de Comédia, entidade sem fins lucrativos formada por duzentas figuras da sociedade paulistana, com o intuito de levantar fundos para sua criação e funcionamento, contava com "dezoito camarins, duas salas de ensaio, uma sala de leitura, uma sala de carpintaria e marcenaria, uma sala de administração, um almoxarifado de guarda-roupa, um almoxarifado de objetos de cena e um depósito de cenários usados e móveis de cena, além dos equipamentos de luz e som, contando com pessoal especializado e remunerado que dela se ocupava" ${ }^{, 17}$. Dessa forma, começaram a contratar os atores que atuariam no TBC. A primeira contratada foi Cacilda Becker, seguida por Maurício Barroso e Madalena Nicol, que acabou por dirigir também Ingenuidade (The Voice of the Turtle) de John Van Druten, o primeiro espetáculo com o núcleo de atores profissionais do TBC. Porém, o grande passo para a

\footnotetext{
${ }^{17}$ GUZIK, Alberto. “TBC: Crônica de um Sonho”. Ed Perspectiva. São Paulo. p. 122
} 
profissionalização se deu com a contratação do italiano Adolfo Celi para ser o diretor artístico do $\mathrm{TBC}$, por indicação do cenógrafo Aldo Calvo que se encontrava em São Paulo. Celi estava em Buenos Aires onde dirigiu a versão de Antígone, de Sófocles para o Teatro Experimental de Buenos Aires, e aceitou o convite do conterrâneo. Seguiu-se a contratação de outros atores como Sérgio Cardoso, Fredi Kleeman, Carlos Vergueiro, Valdemar Wey, Célia Biar, Marina Freire e Ruy Affonso. Finalmente, no mês de junho, aconteceu a estréia do texto The Time of Your Life, de William Saroyan, traduzido como Nick Bar...álcool, brinquedos e ambição, sob a direção do próprio Adolfo Celi, dando prosseguimento à profissionalização do TBC. Contudo, a profissionalização do grupo não figurou apenas no fato do recebimento de estipêndio para a atuação, mas principalmente pela qualidade interpretativa que começou a ser ressaltada. Tal característica é vislumbrada por Décio de Almeida Prado em artigo para o jornal O Estado de São Paulo, em 12 de junho de 1949:

“ O trabalho dos amadores paulistas já vinha sendo de primeiríssima ordem nestes últimos tempos, mas sempre no sentido da maior naturalidade e discrição possível. Celi modificou ligeiramente tais características, dando ao elenco do TBC um senso de espetáculo, mais teatralidade, uma tonalidade mais agressiva e mais viva, de acordo, aliás, como caráter da peça. O rendimento que obteve dos atores, nesse ponto, foi excelente."

Seguiram-se a essa montagem diversas outras, com grande sucesso, como Arsênico e Alfazema (Arsenic and Oldlace), de Joseph Kesselring; Luz de Gás, de Patrick Hamilton; Ele, de Alfred Savoir; O Mentiroso (Il Bugiardo), de Carlo Goldoni; Entre Quatro Paredes (Huis Clos) de Jean-Paul Sartre; A Ronda dos Malandros (The Beggar's Opera), de John Gay; O Anjo de Pedra (Summer and Smoke), de Tennessee Williams. Textos comerciais alternavam-se com textos experimentais, tendo sido criado pelo grupo o chamado Teatro de Segunda-feira, onde peças curtas eram apresentadas.

Dessa forma, o TBC vinha se impondo no cenário paulista e no cenário nacional, como referência para a classe teatral. Apesar do sucesso do grupo Os Comediantes, do Rio de Janeiro, era São Paulo quem liderava a mudança no cenário artístico nacional. Isso se deveu, entre outros fatores, à importação de diretores estrangeiros, na sua 
maioria italianos, que se revezavam na direção de seus espetáculos, trazendo sua experiência de um teatro europeu para a formação dos atores brasileiros e também na de novos diretores que aqui se lançavam. Essa influência estrangeira faz-se notar quando da crítica recebida pela apresentação do espetáculo A Dama das Camélias, de Alexandre Dumas Filho, no Teatro Municipal do Rio de Janeiro, como forma de comemorar os três anos de criação do TBC. Os críticos teatrais demonstraram má vontade com o grupo paulista, acusando-o de "italianismo", referindo-se ao sotaque dos atores, acreditando ser conseqüência do excesso de diretores italianos que se ocupavam de seus espetáculos.

Não obstante, a produção do TBC, já em 1953, continuava com toda força, se impondo nacionalmente e, segundo Décio de Almeida Prado, tendo uma posição, em São Paulo, comparável a da Comédie Française, em Paris. O quadro fixo da companhia era composto por dezoito atores, quatro encenadores (Celi, Ziembinski, Salce e Bollini), um cenógrafo (Bassano Vaccarini), onze auxiliares e treze funcionários.

\section{Abre-se a cortina}

A chegada de Gianni Ratto ao Brasil, convidado por Sandro Polloni e Maria Della Costa, para dirigir o espetáculo de inauguração do Teatro Maria Della Costa, sede própria de sua companhia, o Teatro Popular de Arte, finalmente acontece em janeiro de 1954.

Enquanto ao Teatro Maria Della Costa era preparado para a inauguração, o texto de estréia traduzido, e datilografado, Gianni Ratto se ocupou do Departamento de Teatro do MASP, uma vez que havia conhecido seu diretor, o também italiano Pietro Maria Bardi, através de amigos comuns, quando de sua visita à Itália em busca de obras para formar o acervo do Museu. Bardi aceitou a proposta de Gianni Ratto para a criação do referido departamento, que contaria com a participação do Teatro Maria Della Costa e que tinha como objetivo a leitura de textos teatrais, apresentação de conferências, realização de debates públicos, e convites de espetáculos, bem como o projeto de um concurso nacional para um texto teatral. 
Os ensaios para a estréia do espetáculo que trouxe Gianni Ratto para o Brasil, e que o projetaria como diretor, finalmente tiveram início. $\mathrm{O}$ texto escolhido pelo diretor para a inauguração do teatro seria O Canto da Cotovia (L'Alouette), de Jean Anouilh. Além de dirigir o espetáculo, Gianni assinava também a cenografia composta de plataformas de madeira interligadas por escadas, elementos góticos estilizados nas paredes de fundo, imprimindo um tom solene e grandioso a esta que era sua primeira encenação no país, e sua primeira como diretor. Completavam a harmonia visual os figurinos coloridos e inteligentemente estilizados da também italiana Luciana Petrucelli, sua esposa na ocasião.

Entusiasmado com a realização, escreveu o crítico Décio de Almeida Prado sobre a montagem paulistana, que estreou em outubro de 1954:

"O ideal, no teatro, é que o cenário e a encenação nasçam de um só e mesmo instante de inspiração, explicando-se um pelo outro. Em "O Canto da Cotovia" ambos devem-se à inteligência e à intuição teatral de Gianni Ratto. Essa a primeira grande qualidade do espetáculo do Teatro Maria Della Costa: uma unidade visual perfeita, englobando tudo, desde a disposição da cena até os movimentos dos atores. (...) Tomando em mãos um elenco heterogêneo e recémformado, constituído por veteranos e principiantes, profissionais e amadores, vindo das experiências teatrais as mais diversas, conseguiu, em apenas dois ou três meses, incutir-lhe muita homogeneidade, baseada principalmente na discrição e o bom gosto. Ninguém representa demais, nem de menos, ninguém procura a ênfase que ainda hoje se associa, às vezes, erradamente, ao gênero histórico. A representação é simples, natural, sóbria. "18

A montagem ganha o prêmio Saci de melhor espetáculo. Gianni Ratto o de melhor diretor e cenógrafo e Maria Della Costa o de melhor atriz. No ano seguinte, monta com a mesma companhia o espetáculo Com a Pulga Atrás da Orelha (La Puce a l'Oreille), de Georges Feydeau, além de lançar um novo dramaturgo brasileiro, Jorge

\footnotetext{
${ }^{18}$ PRADO, Décio de Almeida - O Canto da cotovia. In “Apresentação do Teatro Brasileiro Moderno. São Paulo. Editora Perspectiva:2001, p227.
} 
Andrade, com a montagem de A Moratória, revelando o talento dramático de Fernanda Montenegro, pela primeira vez atuando como protagonista.

Importante lembrar, quanto à montagem do texto de Jorge Andrade, que o papel feito por Fernanda Montenegro deveria, a princípio, ser interpretado por Maria Della Costa, dona da companhia, o Teatro Popular de Arte. Apesar disso, Gianni Ratto, com habilidade, vislumbrou que a personagem não teria o perfil da atriz, adequando-se muito mais, na sua concepção, à estreante Fernanda Montenegro. A generosidade com que Maria Della Costa abriu mão do papel em favor da nova atriz sempre foi lembrada por Gianni com muito carinho e admiração:

"Maria naquela época, foi de uma generosidade excepcional. Pois eu li o texto e vi que não haveria papel para ela, então tive a coragem de pedir que desse o papel a Fernanda, que estava começando e quem eu via ser a atriz mais indicada para o papel. E ela não vacilou nem um instante acatando minha sugestão em benefício da montagem, da trajetória de sua companhia." 19

Décio de Almeida Prado fala também do espetáculo, do ponto de vista do diretor:

“(...) também do ponto de vista da encenação A Moratória é um impressionante triunfo. O Canto da Cotovia e Com a Pulga atrás da Orelha já haviam revelado, em Gianni Ratto, uma rara visão global do espetáculo, uma capacidade incomum de movimentar harmoniosamente um grande elenco e de apreender o tom que convém a um texto literário. Estas mesmas qualidades tornamos a reencontrar em A Moratória, na solução do cenário (dois cenários dentro de um só, sem comprometer a unidade do todo) ou na precisão com que são executadas as passagens de um para outro plano. Mas o caso agora era diverso: a peça de Jorge Andrade apóia-se inteiramente, não sobre o espetáculo, mas sobre o desempenho individual dos atores. Propunha, portanto, uma nova prova para Gianni Ratto, que a venceu

\footnotetext{
${ }^{19}$ Depoimento de Gianni Ratto ao autor da dissertação em setembro de 2004.
} 
com a maior maestria, oferecendo-nos uma representação primorosa, pouco menos do que perfeita, uma das melhores que já vimos em palcos nacionais. Dedicando três meses aos ensaios (quando o texto era de encenação materialmente fácil, não exigindo um elenco numeroso), Ratto conseguiu que seus atores se despojassem de toda teatralidade fácil, impregnando-se lentamente das personagens e de uma certa indefinível atmosfera. Esse é o milagre da encenação: o de ser tão simples, tão verídica, não acrescentando nada à peça, no sentido de achados exteriores. Fez o mais dificil: deixou as personagens serem livremente sentimentais, sem elas mesmas o serem. Na comoção, guardou o mais possivel o senso de recato e medida. "20

Confirmando seu prestígio na cena nacional, é contratado, em 1956, pelo Teatro Brasileiro de Comédia, TBC. Dessa forma, a companhia de Maria Della Costa fica também desfalcada de atores, pois Fernanda Montenegro, Sérgio Britto, Fernando Torres e Ítalo Rossi deixam também o grupo decididos a seguir seu novo mestre, Gianni Ratto.

Inicialmente, começam a ensaiar a adaptação de Crime e Castigo, de Dostoievski, na versão de Gaston Baty, sendo ela abandonada para dar lugar a um texto mais prestigiado de Jean Anouilh, Eurydice, sugerido por Ziembinski. A propósito do abandono da primeira peça pela montagem de Anouilh, Gianni relata, referindo-se principalmente à estrutura mantida pelo TBC na época:

“A não ser no Teatro Alla Scala, nunca tinha tido experiência de trabalho numa grande organização, não conhecia seus macetes nem o jogo de interesses compostos que interferiam na realização dos projetos. Distribuindo os papéis fui esbarrando em vaidades e insatisfações que encontraram respaldo no apoio que a diretoria estava dando ao jogo sorrateiro das reclamações: a montagem da

\footnotetext{
${ }^{20}$ PRADO, Décio de Almeida: crítica ao espetáculo "A Moratória”. Estado de São Paulo, coluna Palcos e Circos, 13.05.1955.
} 
peça foi cancelada. Em banho-maria fiquei aguardando outra possibilidade. "21

Os papéis principais da montagem de Eurydice couberam a Cleyde Yáconis e Walmor Chagas, e mais uma vez, Décio elogia o trabalho do diretor:

“Gianni Ratto dirigiu Eurydice como dirigiu, por exemplo, A Moratória ou $\boldsymbol{O}$ Canto da Cotovia, com a mesma humildade, o mesmo carinho, a mesma humanidade, qualidades que são suas, como pessoa, antes de serem características do encenador. , 22

Numa entrevista a Sábato Magaldi, em parte transcrita no belo livro de Alberto Guzik sobre o TBC, antes da estréia do espetáculo, Gianni observa que "a posição existencial de Anouilh é facilmente destrutivel. Não basta, como ele faz, tomar exemplos do acomodamento cotidiano e na base desses exemplos definir a vida”, completando que "se a vida fosse como Anouilh a descreve, o próprio Anouilh não poderia existir. A metáfora que me ocorre para explicar sua posição seria a de um indivíduo que ergue um edifício e em seguida nos prova que o edifício irá ruir ${ }^{, 23}$.

Apesar do esmero com que a montagem foi tratada ela, desde seu ensaio já prenunciava o malogro do espetáculo. Gianni Ratto escreve a Zampari uma carta reclamando do comparecimento de amigos do empresário durante os ensaios que realizavam, principalmente em virtude do burburinho que formavam, exigindo dele providências, proibindo a presença de qualquer pessoa estranha aos trabalhos em curso. Essa atitude foi tomada por conta da presença frequente dessas figuras da sociedade que, sem qualquer consulta, cismavam em aparecer e atrapalhar a concentração dos atores. Sobre esse episódio comentou Gianni Ratto:

"As perigosas relações públicas foram responsáveis pelo futuro malogro do espetáculo: Zampari, industrial e homem da sociedade, achava por bem fazer participar seus amigos, colegas e conhecidos

\footnotetext{
${ }^{21}$ RATTO, Gianni. A Mochila do Mascate, p. 251. São Paulo. 1996. Editora Hucitec.

${ }^{22}$ PRADO, Décio de Almeida. O Estado de São Paulo, 12.08.1956. In: Dionysos, n.25

${ }^{23}$ GUZIK, Alberto. “TBC: Crônica de um Sonho”. Ed. Perspectiva. São Paulo. p. 136
} 
"in" nos trabalhos relativos à montagem de um espetáculo; no decorrer de um ensaio, portanto, era comum termos a sala invadida por gente elegante que, tentando ser delicada, trazia um zumbido e uma ventania de movimentos que nos distraíam, perturbando-nos, de nosso trabalho. Como numa corte francesa molieresca, os convidados nos olhavam sorrindo afavelmente enquanto tomavam o chá e os biscoitinhos elegantemente oferecidos pela direção desse, hoje defunto, organismo. "24

Não obstante, os problemas durante sua montagem, o espetáculo resulta muito bom. Sábato elogia a montagem do diretor, principalmente quanto à interpretação dos atores.

“... Na tarefa de obter bom rendimento dos intérpretes, mais uma vez Gianni Ratto mostrou suas qualidades excepcionais de diretor. Walmor Chagas tem o melhor desempenho de sua carreira, sóbrio, humano, comovido. Cleyde Yáconis, embora algo declamatória, consegue exprimir a fatalidade do amor de Eurydice. Fredi Kleeman dá dignidade aos lugares-comuns de Monsieur Henri. Todos os papéis são vividos com extremo cuidado, fazendo-nos admirar que o TBC possa dar-se ao luxo de ter Fernanda Montenegro, Elisabeth Henreid e Elísio de Albuquerque em pequenas intervenções $" 25$.

Com cenários que Sábato Magaldi lembra entre os mais belos já criados no Brasil, música para violino, composta por Diogo Pacheco e executada por Milton Kanji, belíssimos figurinos de Luciana Petrucelli, e apesar dessa caprichada montagem receber elogios, o público não se entusiasma com sua realização, e a temporada da peça termina com um lamentável episódio, onde todos os elementos cênicos são desmontados e queimados, por ordem do empresário Franco Zampari, num rompante de ira após um desentendimento pessoal com Gianni Ratto, que se somava ao episódio da proibição de pessoas assistirem aos ensaios, fato que o próprio Zampari, no dizer de Gianni,

\footnotetext{
${ }^{24}$ RATTO, Gianni -A Mochila do Mascate, p 251. São Paulo. 1996. Editora Hucitec.

${ }^{25}$ Teatro Brasileiro, $n^{\circ} 9$, p. 43.
} 
entendeu ser estendida a ele, o que não era verdade. Poderia ter sido pior. Porém, com a obrigação de honrar o contrato assinado com o diretor, o TBC tranfere-o para o Rio de Janeiro, onde dirige, no Teatro Ginástico (sede carioca do TBC), o espetáculo Nossa Vida Com Papai (Life With Father), de Lindsay e Crouse, peça que ficou dez anos em cartaz na Broadway. O espetáculo torna-se um estrondoso sucesso de público, atraindo quase vinte e nove mil espectadores para suas cento e cinqüenta récitas, vindo para São Paulo com a missão de repetir o êxito carioca.

A gravidade da desavença de Gianni Ratto com Franco Zampari é observada por Guzik:

"Não havia dúvida quanto à capacidade e seriedade do encenador, atestadas seja por sua atividade na Itália, seja pelo trabalho que desenvolveu à frente do conjunto de Maria Della Costa. Quando Ratto regressou a São Paulo com a triunfante comédia norteamericana, o TBC acabara de perder seu diretor artístico. Depois dos fracassos consecutivos de As Provas de Amor e A Rainha e os Rebeldes, Vaneau regressara para a Europa. Não chegou a sair do país propriamente indisposto com o empresário, mas a situação de mal-estar que se seguiu aos dois fiascos propiciou sua partida. Mesmo considerando esse quadro, Zampari sequer pensou na hipótese de superar a divergência que o afastava de Ratto e convocálo para o cargo vacante. Nem a repetição paulista do êxito carioca de "Nossa Vida com Papai" conseguiu levá-los à reconciliação. ,26

Em 1958, pego de surpresa, lhe é feito um convite para trabalhar no Teatro da Universidade Federal da Bahia (UFBA), em Salvador. Dessa feita, desliga-se do TBC, transferindo-se para Salvador junto com sua esposa, Luciana Petrucelli, onde permaneceu por um ano. Amava a cidade, a escola e os alunos. Lá, ele dirige As Três Irmãs, de Anton Tchekov, e O Tesouro de Chica da Silva, de Antonio Callado. Na UFBA trabalhou também como professor do curso de teatro, ensinando cenografia,

\footnotetext{
${ }^{26}$ GUZIK, Alberto. TBC: Crônica de Um Sonho - O Teatro Brasileiro de Comédia 1948-1964. p.29/30.Editora Perspectiva 1986.
} 
artesanato e história da cenografia. Tinha como colegas Domitila do Amaral, professora de interpretação; Brutus Pedreira (crítico e tradutor) que ensinava dramaturgia juntamente com João Augusto Azevedo; J. H. Koellreuter, diretor da Escola de Música; Yanka Rudzka, professora de dança e expressão corporal, além de Luciana Petrucelli, figurinista, que ensinava história do traje e da confecção, entre outros professores. Após o término de seu contrato, Gianni retornou a Itália, onde permaneceu durante um ano. Nesse período, manteve correspondência constante com Fernanda Montenegro, Fernando Torres e Sérgio Brito, que lhe falavam do sonho de criar uma companhia, um empreendimento que deveria reunir pessoas com os mesmos ideais, mesmas intenções e seriedade profissional. Graças ao trabalho que esses atores estavam realizando na televisão, mais especificamente no Grande Teatro Tupi, o que lhes dava um suporte financeiro e a conquista de um público fiel que os acompanharia em suas montagens, o sonho tornou-se possível e, assim, convidaram Ratto para retornar ao Brasil, e estabelecer-se no Rio de Janeiro e, assim, criar com eles a nova companhia, que teria o nome de Teatro dos Sete. O nome se devia ao número de seus fundadores que, além dos artistas mencionados, incluía também a esposa de Gianni, a figurinista Luciana Petrucelli, e Alfredo Souto de Almeida. Luciana, na última hora decidiu não voltar ao Brasil, mas mesmo assim idealizou os figurinos para o segundo espetáculo que realizariam. Apesar de ela não permanecer no grupo, assim como Alfredo Souto de Almeida, ficou mantido o nome Teatro dos Sete, durante toda a duração da companhia.

\section{O Número da Criação - O Teatro dos Sete.}

Não obstante a correspondência mantida entre Gianni e os componentes do futuro Teatro dos Sete, é bom lembrar que seu embrião surgiu na convivência do grupo durante sua permanência no Teatro Popular de Arte, de Maria Della Costa e Sandro Polônio.

Fernanda Montenegro, Fernando Torres, Sérgio Britto e Ítalo Rossi ainda eram contratados pelo TBC. Com a saída de Cacilda Becker da companhia de Franco Zampari, Fernanda Montenegro, que já vinha se firmando no grupo com destaque, passou a ocupar lugar de maior importância, lugar esse consagrado pela sua atuação em Vestir os Nus (Vestire gli Ignudi) de Pirandello, apresentado também no Teatro Ginástico, no Rio de Janeiro. 
Cansados de tantas viagens, principalmente pelo fato de terem de conciliar as apresentações teatrais com suas participações na televisão, os atores decidem deixar o TBC e fixar-se definitivamente no Rio de Janeiro a fim de realizar o sonho a tanto tempo acalentado, agora que Gianni Ratto voltaria para o Brasil.

O espetáculo de estréia do novo grupo foi O Mambembe, de Arthur Azevedo. A escolha do texto foi apresentada por Fernanda Montenegro e a peça fascinou o diretor, principalmente por ter como tema um grupo de teatro.

Sobre a escolha do texto, Fernanda Montenegro relata:

"Quando a gente foi fazer O Mambembe, toda a esquerda, todo o país, estava vivendo um momento muito complicado. Era a mudança de capital, Juscelino terminando o Governo, entrando o Jânio enfim, as coisas apontando. Eu me lembro que Paulo Francis quase cortou relações conosco, como é que nós iríamos fazer um autor bobo, um autor sem nenhuma expressão, enquanto que lá na Europa tinha Ibsen, Strindberg...Tinha uma autor aqui que escreveu A Almanjarra, escreveu Um genro de Muitas Sogras. E interessante, porque ao fazermos $\boldsymbol{O}$ Mambembe também...mas um elenco imenso. Ah, sim, tinha uma banda com seis músicos. Nós fizemos no Theatro Municipal porque, por acaso, veja como são as coisas, eram 50 anos do Teatro Municipal, que foi feito pelo Arthur de Azevedo ${ }^{27}$, esse teatro maravilhoso aqui do Rio de Janeiro. E não tinha quem fizesse esse autor, por que esse autor estava sabe, lá nas calendas... ,28

O grupo, ainda encontrava-se sem dinheiro suficiente para a montagem de uma peça grandiosa como essa, composta de 84 pessoas e que tinha em sua concepção uma orquestra ao vivo. Porém, o grupo contou com alguns pontos históricos a seu favor: coincidentemente, naquele ano o Theatro Municipal completava 50 anos e, além disso,

\footnotetext{
${ }^{27} \mathrm{Na}$ verdade Arthur Azevedo foi o idealizador, e batalhador por uma casa de espetáculos nacional, daí ela dizer que foi ele quem construiu o Theatro Municipal do Rio de Janeiro.

${ }^{28}$ Entrevista concedida por Fernanda Montenegro ao autor da dissertação, em agosto/2006.
} 
Arthur Azevedo - praticamente esquecido pela classe artística - havia sido a pessoa responsável por sua construção. Resultado: o grupo foi convidado a encenar a peça do autor na própria casa de espetáculos como celebração das festividades de seu cinqüentenário e, ainda, conseguiu o empréstimo dos figurinos necessários para a apresentação. Para minimizar os custos da montagem e formar um capital inicial, o grupo criou assinaturas para os espetáculos, que seriam solicitadas aos espectadores do programa que faziam na televisão, para que pudessem dar continuidade ao empreendimento. Isso pode ser constatado no depoimento de Fernanda Montenegro.

"Nós fizemos no Theatro Municipal porque, por acaso, veja como são as coisas, eram 50 anos do Theatro Municipal, que foi feito pelo Arthur Azevedo, esse teatro maravilhoso aqui do Rio de Janeiro. E não tinha quem fizesse esse autor, por que esse autor estava lá nas calendas... Acabamos pedindo as roupas no Municipal, não é? Tínhamos feito assinaturas no programa de televisão, não sei se Sérgio contou isso. No Grande Teatro Tupi. Nós estávamos já há algum tempo fazendo um teleteatro semanal, com muito humor, com muito cuidado. Aí, não tem dúvida... O Sérgio Britto foi pro, imagine como éramos pioneiros nessa época na televisão, e disse "Olha esse grupo, o grupo idealizador e condutor do Grande Teatro Tupi, que vocês conhecem já de alguns anos, nós estamos pretendendo fazer um grupo de teatro, uma companhia de teatro. "E queremos oferecer a vocês assinaturas pra que a gente possa ter um fundo pra começar a companhia. Foi tudo claro. Em contrapartida nós damos quatro assinaturas, uma assinatura de quatro espetáculos. Uma assinatura de quatro espetáculos. Que seriam O Mambembe, A Profissão da Senhora Warren, Cristo Proclamado, e Beijo no Asfalto. Nós levantamos um dinheiro bom, com uma mesinha aqui na Siqueira Campos e essa gente de televisão que via nossos programas de televisão que iam pro ar assim umas dez e meia, onze horas da noite. Nós levantamos um capital básico. Agora, não dava para os quinhentos figurinos, não dava! Dava pra gente se estimular. Daí dissemos:" Vamos ao Municipal e vamos pedir emprestado as roupas do acervo do Municipal". E fomos recebidos pelo diretor do 
Municipal que disse - Mas vocês querem fazer...vocês querem fazer Arthur Azevedo? Nós dissemos - Queremos. - Pois então ótimo, porque ninguém quer fazer Arthur de Azevedo. Estamos comemorando os cinqüenta anos do teatro, então nós damos os figurinos, damos os cenários e ainda damos quinze dias no Teatro pra vocês. Foi assim que a nossa companhia começou. "29

O espetáculo seguinte do grupo foi A Profissão da Senhora Warren (Mrs. Warren's Profession), de George Bernard Shaw, que, entretanto, não alcançou o mesmo êxito do espetáculo anterior. Em seguida, veio a montagem de Cristo Proclamado, um difícil texto do autor nacional Francisco Pereira da Silva, contendo grande dose de denúncia social, extremamente realista e panfletária revelando a dura vida no sertão do Piauí.

Gianni optou por um palco inteiramente limpo, com uma equipe de trinta e dois atores. Para sua montagem, foram feitas até pesquisa de campo para melhor elaboração das personagens. A temática abordada pela peça, também constituía elemento dificultador para o sucesso do espetáculo. O episódio é lembrado por Sérgio Britto:

"Nós tomamos um susto. A peça era dificílima e era muito estranha pra época. Numa cidade do interior vai se fazer a representação da Semana Santa, e quem faz o papel do Cristo é eleito prefeito da cidade. Então, eu vinha de fora, recém formado em advocacia, filho do papai rico, pra ganhar o papel do Cristo, e ganhar a eleição. Chego lá, ninguém simpatiza comigo e o papel do Cristo fica com o médico. Então na hora da representação toda aquela turma do interior, imagina só uma rampa, só tinha uma rampa, uma rampa e uma árvore. Só isso em cena. Olha como ele era avançado. Aquela gente toda se vestia de romeiro e saia pela rua fazendo a história de Cristo. Tô lá em cima da montanha, junto com meus asseclas, e Cristo tá passando lá embaixo. Qual é o golpe dele? Ele mata o Cristo. Dá um tiro de revólver e mata o Cristo, e mata dois

\footnotetext{
${ }^{29}$ Entrevista concedida por Fernanda Montenegro ao autor da dissertação, em agosto/2006.
} 
que estavam ao lado dele, dizendo que eles é quem mataram o Cristo. Ele vira herói e é eleito prefeito. Assim termina a peça. Uma peça muito difícil, muito seca. Era uma hora de espetáculo. Um fracasso monumental, fora de qualquer medida". ${ }^{30}$

O espetáculo foi apresentado no teatro do Hotel Copacabana Palace, pouco apropriado ao tema apresentado e considerado pobre em recursos. Além disso, a aridez da temática levantada era pouco condizente com o público que o freqüentava. Com toda essa repercussão negativa, o espetáculo é retirado de cartaz após três semanas de apresentações. Sérgio continua:

"Nós estreávamos uma peça naquela época. Estreávamos na quarta, no sábado já estava lotado e já estava lotado para o outro sábado. Em Cristo Proclamado, no primeiro sábado nós tivemos cinqüenta pessoas, no outro nós tivemos quarenta. Ficou em cartaz durante três semanas.

A peça, para aquela época, era muito avançada. Era avançada demais. As pessoas não entendiam aquela linguagem, aquela frieza. Imagina só o seguinte, todos os retirantes, tudo com aquele pano na cabeça, amarrado, pé descalço. Me lembro da Zilka (Zilka Salaberri) na frente com uma trouxa debaixo do braço, e eu com um microfone, de costas pra platéia, fazendo um discurso prometendo que nunca mais ia deixar de chover. Eles acreditavam e votavam em mim. Você imagina!! ${ }^{31}$

Sérgio comenta que a crítica e o autor não concordavam com a reação do público. Sua visão do espetáculo era bem diferente:

“...o Francisco ${ }^{32}$ achava lindo tudo aquilo. A peça saiu de cartaz e a crítica, os jornais foram contra nós: Eles tinha a obrigação de manter a peça, não sei o quê... Mas a verdade é que quem ia pagar o elenco. Eram trinta pessoas no elenco. Tivemos que tirar. E ele concordou em tirar. Nós, pra podermos sustentar e não despedir um elenco de trinta pessoas, porque nós sempre tivemos uma preocupação, digamos social, nós remontamos $\boldsymbol{O}$ Mambembe e saímos viajando com $\boldsymbol{O}$ Mambembe pra Niterói. „33

\footnotetext{
${ }^{30}$ Entrevista concedida por Sérgio Britto ao autor da dissertação em agosto/2006.

${ }^{31}$ Entrevista concedida por Sérgio Britto ao autor da dissertação, em agosto/2006.

${ }^{32}$ Francisco Pereira da Silva (1918-1986) - autor de Cristo Proclamado.

${ }^{33}$ Entrevista concedida por Sérgio Britto ao autor da dissertação, em agosto/2006.
} 
É contrária, no entanto a opinião da crítica teatral Bárbara Heliodora quanto ao entendimento do texto de Francisco Pereira da Silva:

“Eu já briguei, discuti e não sei o que, cem mil vezes. Eu, que adoro o Chico Pereira da Silva (o autor), acho que a peça não funciona. Acho que o problema é com a peça. Acho, que o paralelo do sofrimento do nordestino com o sofrimento de Jesus, que o Chico não conseguiu dar uma vida teatral válida a esse problema. Então, o espetáculo não funcionava, não funcionava porque não havia jeito de fazer funcionar isso é que eu acho, não é que estivesse mal feita. Daí eles ficam revoltados, dizem que o público é que não entendeu. Não adianta!! Não era vanguarda coisa nenhuma. Era um espetáculo muito bem feito de uma coisa que não funcionava. Eu lembro a minha sensação na noite de estréia. É uma coisa que raramente a gente sente, um grande buraco entre a platéia e o palco. Sabe, como quando o espetáculo não chega? Não adiantava nada na vida aquilo. E eu adoro a maior parte das coisas do Chico Pereira da Silva. Mas pra mim o problema é o texto. Eu acho que nessa peça ele não conseguiu fazer funcionar a idéia. Então por mais que você fizesse, e eles fizeram com um cuidado enorme, mas foi um fracasso retumbante. Mas realmente acho que a culpa não é deles, nem dos atores, nem do Ratto, eu acho que infelizmente o texto não funciona. Eu acho que esse é o segredo do fracasso do Cristo Proclamado, que aliás o título é lindo! Mais bonito que Cristo Proclamado é impossivvel. O texto não funciona ${ }^{, 34}$.

A montagem de Com a Pulga Atrás da Orelha, de Georges Feydeau, anteriormente realizada por Gianni quando ainda estava no Teatro Popular de Arte, de Maria Della Costa, traz novamente o sucesso ansiado pelo grupo. Dessa feita, o espetáculo faz longa carreira, tirando também o grupo de dificuldades econômicas que se encontravam em virtude da baixa repercussão dos dois espetáculos anteriores.

\footnotetext{
${ }^{34}$ Entrevista concedida ao autor da dissertação por Bárbara Heliodora, em agosto/2006.
} 
Tratava-se de um espetáculo primoroso, elogiado por público e crítica, principalmente pelo crítico e fundador do Old Vic, George Devine ${ }^{35}$, que passava por Curitiba, a convite da Cultura Inglesa para realizar palestras, já tendo estado em São Paulo, onde dirigiu uma leitura com Ziembinski e Cacilda Becker. Ao assistir a montagem de Com a Pulga atrás da Orelha, realizada pelo Teatro dos Sete, comentou, como relata Fernanda Montenegro:

"Ele ficou abismado com a qualidade do Feydeau. Ele dizia assim: É fantástico, se nós fazemos Feydeau (referindo-se aos ingleses), nós vamos fazer um Feydeau à inglesa. Nós temos uma tal escola, nós temos uma tal herança cênica que, por mais que a gente queira se libertar, a gente queira fazer, não consegue, porque a escola, ela marca a empostação, marca, tudo marca. Então, se nós fizermos um autor francês nós vamos fazer um autor francês como se ele fosse inglês. Eu estou vendo este Feydeau absolutamente liberto. Vocês são libertos. Não há uma escola, existe um espírito em cena, existe um deleite em cena, que não pertence, eu nunca vi, não sei que tipo de educação teatral vocês têm, mas vocês têm uma dinâmica cênica que é alucinante. Isso vendo Feydeau, dirigido pelo Ratto. "36

No ano de 1961, após a montagem de Apague Meu Spot Light, uma comédia de Jocy de Oliveira, o grupo se dedica ao ensaio de um texto de Nelson Rodrigues, Beijo no Asfalto e, em virtude de alguns desentendimentos havidos no grupo pela primeira vez, Gianni não assina a direção, da qual ficou incumbido Fernando Torres. Mais uma vez, Sérgio Britto nos fala sobre esse período:

“...Com a Pulga Atrás da Orelha, que nos salvou. Foi um ano de sucesso. Depois da Pulga veio o Beijo no Asfalto, que o fi-lo porque quilo (Jânio Quadros) destruiu. Que era um sucesso devastador. O Beijo no Asfalto foi um escândalo. Foi uma coisa fora do comum. Eu acho que uma das melhores peças do Nelson. Até Dona Bárbara

\footnotetext{
${ }^{35}$ GEORGE Alexander Canady DEVINE (1910-1965), ator e diretor importante do teatro inglês, foi diretor do Old Vic. Foi criador de um premio para auxiliar jovens profissionais de teatro, o George Devine Award, em 1966.

${ }^{36}$ Entrevista concedida por Fernanda Montenegro ao autor da dissertação, em agosto/2006.
} 
(Bárbara Heliodora) acha bom. A Bárbara acha a melhor peça dele. Não sei se é a melhor peça dele, mas é uma peça ótima. Depois nós fizemos...Fomos pra Maison de France, porque aí a desordem social e econômica que gerou a saída do Gianni, fez tudo cair. Nós fomos pra Maison de France porque era mais barato", 37

Desentendimentos resolvidos, Gianni Ratto volta a assinar a direção dos espetáculos. E o grupo consegue mais um êxito com a montagem de Festival de Comédia, um espetáculo que reunia três textos curtos de Martins Pena, Molière e Cervantes, respectivamente Ciúmes de um Pedestre, O Médico Volante, e O Marido Ciumento. Um espetáculo fascinante que mostrava claramente o trabalho do ator na composição de personagem.

"Ai fizemos um dos melhores espetáculos de nossas vidas, Festival de Comédia, era Martins Pena, aliás, na ordem era: Cervantes, Molière, Martins Pena. Um espetáculo inacreditável. O Cervantes era uma tábua com uma inclinação, com uma cortina. Eles na rua. Depois, o Molière já era feito num palco, com um cenário todo elaborado, tinha uma casa de dois andares. O Ítalo (Ítalo Rossi) subia como um personagem e descia como outro, só mudando uma coisa, era uma coisa impressionante. E no final nós fazíamos do Martins Pena, Os Delírios de um Pedestre, que também era um delírio danado. Naquela época, nós éramos os atletas do teatro. Pra você ter uma pequena idéia, se o Ítalo subia o cenário e descia como outro personagem. No Martins Pena, eu tinha um ataque de fúria, pulava do palco na platéia, corria até o fundo do teatro, voltava correndo, subia no palco outra vez. Eu nem sei como eu fazia uma coisa dessas. E fazia! Agora já não foi muito bem, mas se sustentou porque o Maison de France era barato, "38 lembra Sérgio Britto.

\footnotetext{
${ }^{37}$ Entrevista concedida por Sérgio Britto ao autor da dissertação, em agosto/2006.

${ }^{38}$ Entrevista concedida por Sérgio Britto ao autor da dissertação, em agosto/2006.
} 
Festival de Comédia é seguida pela montagem de um texto de Luigi Pirandello, O Homem, a Besta e a Virtude, em 1962. Texto considerado dificílimo que consegue conquistar público e crítica. Vale relembrar uma cena em que o diretor reproduziu uma imagem da Anunciação, colocando a personagem da Sra. Perella, grávida, sentada, e tendo ajoelhado aos seus pés, seu amante, Paulino emoldurados por um arco como cenário. Uma Anunciação política, considerada por muitos um verdadeiro sacrilégio.

As produções do Teatro dos Sete tornam-se esparsas a partir de 1963, com a realização de apenas uma montagem anual. A última direção de Gianni Ratto para o grupo - que se dissolve em 1965 - será do texto Mirandolina (La Locandiera), de Carlo Goldoni, em 1964.

A dissolução do Teatro dos Sete deixou muita tristeza em seus participantes, principalmente em Gianni Ratto que via no grupo, a princípio, como uma forma de realizar um teatro inovador, de qualidade, que, dentro de seus sete anos de existência, cumpriu a meta estabelecida, apesar dos percalços do caminho. Importante verificar as observações do diretor sobre este período, e sobre o grupo. Ele diz:

"Eu acho que as coisas vivem o tempo que elas precisam, que elas merecem. Porque depois de um certo tempo, começam a ficar... Se você examinar a história do teatro, os grandes grupos, você vai ver que eles têm uma vida que não ultrapassa os sete anos. É muito difícil que um grupo consiga sobreviver sete anos de vida. Por uma razão: porque há um desgaste, uma linha espiral. E principalmente porque há um crescimento das personalidades, que inevitavelmente entram em choque. Isto é saudável. No momento é amargo. Mais tarde, você vê que era justo que assim fosse. Quando o grupo se dissolveu, eu sofri muito, porque era uma coisa na qual eu acreditava. Mas mais tarde, eu vi que tinha, realmente, que se dissolver. Porque o nosso limite era a nossa qualidade. O quantitativo estava sobrepujando os valores mais importantes, de idéia, de intelecto, de criatividade. Então, de repente, o espetáculo era perfeito. Mas era uma perfeição além da qual você não podia ir. 
Mirandolina foi o último espetáculo que fizemos. E eu ouso dizer que era um espetáculo perfeito. Tanto do ponto de vista crítico, como do ponto de vista interpretativo, de direção, de cenário, tudo. Nunca tinha feito um espetáculo tão bom como aquele. Nunca Sérgio foi tão maravilhoso... No Canto da Cotovia, foi maravilhoso. Nos velhos, do Festival de Comédia. Mas em Mirandolina tinha alcançado aquele grau que você pode dizer - é ótimo. E depois? Teatro não pode ser isto. Teatro deve ser uma possibilidade de sempre ir adiante. Se você não lança o coração além do horizonte para correr atrás dele, você não pode mais fazer teatro. Ai, acaba.",39

No ano de 1966, o Teatro Nacional de Comédia (TNC) convida o diretor para dirigir, para sua companhia oficial, seu segundo texto de Jorge Andrade, Rasto Atrás. A montagem alcança sucesso unânime na crítica teatral, que pode ser observada através do seguinte excerto de uma crítica de Yan Michalski, no Jornal do Brasil:

"O comoventemente bonito espetáculo dirigido por Gianni Ratto é pelo menos tão estimulante e renovador quanto o texto. Raramente vimos, nos últimos anos, uma concepção de mise-en-scène tão ousada, tão inspirada, e ao mesmo tempo tão completamente realizada, tão esclarecedora em relação às intenções e às idéias do autor. Desde o espetacular cenário do próprio Gianni Ratto - que aplica, pela primeira vez no teatro brasileiro, ao que parece as técnicas de projeção cinematográfica integrada com ação cênica, tão divulgadas na Europa, e tão eficientes, passando pelos ótimos figurinos de Bela Paes Leme, e culminando com o enorme e coeso elenco que apresenta um punhado de desempenhos de primeira linha e pouquíssimos pontos fracos, em todos os seus elementos, enfim, Rastro Atrás é um espetáculo vibrante de inventividade, de beleza e de verdade", ${ }^{40}$

\footnotetext{
${ }^{39}$ Depoimento de Gianni Ratto a Tânia Brandão, em abril de 1984 para seu livro "Teatro dos Sete - A máquina de repetir e a fábrica de estrelas."Viveiros de Castro Editora Ltda. Rio de Janeiro. 2002. p.258 ${ }^{40}$ MICHALSKI, Yan: Crítica do espetáculo "Rastro Atrás”, Rio de Janeiro, Jornal do Brasil, 26.01.1966. MICHALSKI, Yan: Teatro e Estado, São Paulo-Rio de Janeiro, ed. Hucitec/IBAC, 1992.
} 
O momento político do país contribui para que haja um movimento de nacionalização do teatro brasileiro, que se reflete em grupos como o Teatro de Arena e Teatro Opinião. Gianni Ratto é convidado por este último para montar o texto Se Correr o Bicho Pega, Se Ficar o Bicho Come, de Oduvaldo Vianna Filho e Ferreira Gullar, peça que se torna um dos símbolos da resistência militar. A direção de Gianni Ratto imprime unidade estilística à montagem, sem reduzir a diversidade proposta pelo texto, possibilitando o trânsito pelo universo popular e seus variados tons - do romance de aventura à comédia romântica, da sátira de costumes à comédia rasgada e à farsa, da literatura de cordel ao musical. Essa mistura estilística faz com que Yan Michalski considere o espetáculo uma verdadeira "salada":

“...mas a salada é gostosíssima, e o tempero foi preparado de maneira tão adequada que o sabor de nenhum dos ingredientes destoa demais, nem se impõe abusivamente aos demais. Esse tempero consiste num ângulo de constante charme e humor sob o qual os acontecimentos são vistos - charme e humor genuinamente brasileiros, pois baseados (...) na glorificação de um certo e simpático tipo (...). ",41

Justamente para burlar o monstro da censura que dominava a cultura da época, a linguagem utilizada na montagem, plena de fantasia, imaginação e festa, sobrepujavam a verossimilhança, porém a exuberância formal e satírica do espetáculo não escondia a postura política do Teatro Opinião.

Sua próxima direção, em 1967, acontece no Teatro Cacilda Becker, companhia da atriz e de seu marido Walmor Chagas, com Isso Devia Ser Proibido, texto de Bráulio Pedroso e Walmor, tendo ele e Cacilda no elenco, seguida, na mesma companhia, por Dura Lex, Sed Lex, no Cabelo Só Gumex, de Oduvaldo Vianna Filho, em 1968.

\footnotetext{
${ }^{41}$ MICHALSKI, Yan. "O Bicho que já pegou”, Jornal do Brasil, Rio de Janeiro, 20 de abril de 1966.
} 


\section{A Cena se Abre: O TEATRO NOVO}

Definição de teatro como edifício: Este lugar onde nada existe e tudo pode acontecer.

Gianni Ratto

O Teatro Novo foi um projeto pouco conhecido pelo público, e até da própria classe artística. Não obstante, era uma idéia muito cara a Gianni Ratto e que, infelizmente, apesar de ter dado certo, foi interrompido em virtude de questões políticas pelas quais passava o país.

O começo de sua concretização se deu numa conversa de Gianni com Regina Ferraz, primeira bailarina do Theatro Municipal à época, durante o intervalo de um ensaio. Nesse encontro, ela dizia que pretendia, junto com seu marido o empresário Paulo Ferraz, criar uma companhia de balé onde pudesse ter mais oportunidade do que as que possuía no Theatro Municipal. Como, desde que chegou ao Brasil, o sonho de Gianni era criar no país uma companhia que só montasse textos brasileiros, achou que esta poderia ser a oportunidade, se expusesse suas idéias para o empresário. Apesar de recebê-lo em sua casa, com toda a mordomia e atenção, e após ouvi-lo atentamente, negou o pedido de Gianni. Todavia ofereceu-lhe o cargo de diretor da companhia de dança que pretendia montar com, e para, sua esposa. O convite foi aceito prontamente pelo diretor que vislumbrava a possibilidade de ampliar o campo de sua atividade, aliando seus interesses teatrais aos da companhia de dança.

A companhia criada, que recebeu o nome de Balé do Rio de Janeiro, não possuía lugar próprio para ensaios e isso começou a se tornar um problema, que se tornou mais preocupante com a chegada do coreógrafo americano, maître de ballet, Arthur Mitchell, que necessitava de espaço próprio, com camarins, salas de aula, de ensaio, serviço médico, enfim uma estrutura condizente com a categoria da companhia que se estava criando. O problema foi levado a Paulo Ferraz que, prontamente, concordou que isso deveria ser sanado. Dessa forma, colocaram-se a procura de um imóvel que pudesse abrigar a estrutura pretendida. Mas onde encontrar, na cidade do Rio de Janeiro, um espaço que se adequasse às necessidades? 
Fernando Pamplona, o carnavalesco que por muito tempo tinha sido chefe do setor de cenografia do Theatro Municipal do Rio de Janeiro, recordou-se que o Teatro Phoenix, uma casa de espetáculos, situada na Cinelândia, construída entre o final do século XIX e início do século XX, situada na Cinelândia, com acústica perfeita, por ter sido erguida sobre uma caixa d'água, que possuía camarotes e frisas, e urdimentos metálicos, havia sido demolida recentemente, contrariando lei que proibia essa ação, mas que havia sido realizada com o compromisso da construção de nova casa com mesmas características técnicas. Realmente o Teatro Phoenix havia sido reconstruído, porém em outro local, no Leblon, e encontrava-se na ocasião fechado e sem nenhuma utilização.

A casa de espetáculos no Leblon foi, então, visitada por Gianni, Paulo Ferraz e Fernando Pamplona. O edifício era todo de mármore branco com cerca de novecentos lugares. Nem de longe se comparava à antiga edificação, mas era bastante apropriado para o projeto que pretendiam desenvolver no local. Tanto Pamplona como Gianni passaram insistentemente a persuadir o empresário de que ele deveria o quanto antes se tornar proprietário do imóvel. A negociação com os donos demorou dois meses, ao final dos quais o negócio não se concretizou, pois não queriam que o mesmo fosse vendido. Iniciou-se, então, nova procura pelo edifício ideal para sede da companhia. Mais uma vez foi Pamplona quem descobriu um novo ponto. Trava-se de um teatro situado na Rua Gomes Freire, na Lapa, e que era utilizado apenas para bailes de carnaval de travestis e pouquíssimas apresentações de teatro de revista, o qual hoje em dia é ocupado pela TV

\section{Educativa.}

O edifício encontrado era o antigo Teatro República. Possuía excelente palco, grandes espaços inutilizados e com lotação para mil lugares. Havia uma platéia, balcões, frisas, saguões e dependências variadas, apesar de abandono e da sujeira aparentes, que eram guardados por dois sonolentos vigilantes que, a muito custo, consentiram na vistoria do local pelos interessados. Apesar de não possuir o mesmo charme do primeiro imóvel pretendido e de o edifício necessitar de grandes reformas para sua utilização, mesmo assim, o investimento compensava e resultaria no investimento de uma soma inferior ao custo do outro teatro. E, ainda, tinha a vantagem de que o próprio palco já poderia ser utilizado para os ensaios, sem que atrapalhasse a reforma do restante do imóvel, o que já seria uma grande vantagem. 
Acertado todos os trâmites burocráticos, foi dado início à reforma do edifício, com projeto de remodelagem do próprio Pamplona, que também acompanhava a execução dos trabalhos. As frisas foram eliminadas, assim como foi fechada a frente do segundo balcão, onde seria posteriormente instalada a sala de projeção, cabines de luz e som, sobrando ainda espaço para um estúdio de gravação.

Os ensaios passaram a ser realizados num espaço com capacidade para cinqüenta bailarinos, tendo todas as suas paredes forradas de espelho, com barras fixas e móveis, além de terem sido instalados no local duchas e banheiros. Gianni Ratto, por sua vez, planejava as atividades do teatro nos próximos três anos. Sua intenção era realizar um centro de

“...atividades diferenciadas, todas compatíveis com o espaço do qual dispúnhamos, teóricas e práticas, com a participação de personalidades de cultura humanista, nacionais e estrangeiras. $O$ potencial, a partir da posse de um edifício, era enorme. Não conseguia conceber um teatro que, dedicado ao balé, abrisse às nove da noite, fechando duas horas depois, independendo do fato de ter uma sala de ensaio destinada ao corpo de baile, que ocuparia as horas da manhã. Minha aspiração era chegar a ter todos os espaços disponíveis ativos a partir das oito da manhã até a meia-noite. ",42

Nesse planejamento constava a realização de cursos de cultura musical, história da arte e história do teatro, realização de festivais de música popular, espetáculos de bonecos e marionetes, cursos para a formação de jovens atores, selecionados através de provas de admissão qualitativas, para que, dessa forma, tentasse, futuramente, uma programação teatral experimental com esses alunos. Pretendia também a contratação de espetáculos estrangeiros que estivessem de passagem pela América do Sul. Enfim, tencionava transformar o teatro num verdadeiro centro cultural, mas, para isso,

\footnotetext{
${ }^{42}$ RATTO, Gianni.A Mochila do Mascate p. 126. Editora Hucitec. São Paulo. 1996
} 
precisaria falar com o empresário, dono do teatro. Paulo Ferraz foi muito receptivo às idéias do diretor e concordou com a realização do projeto nessas dimensões.

Com a reforma andando com força total, tendo o local da administração já finalizado e a contratação da responsável pela área, Tatiana Memória, que viria a se tornar esposa do diretor, viu-se a necessidade da rápida finalização de um consultório médico que atendesse artistas e empregados. Logo em seguida, o sonhado grupo de teatro da casa começou a tomar forma, como relata Gianni:

“Abrimos as inscrições para a seleção de jovens elementos para a formação de um primeiro núcleo teatral, e o resultado superou as expectativas: dezenas, entre moças e rapazes, se apresentaram e os testes tiveram início. Não foi um trabalho fácil, se se pensa que a idéia de um espetáculo específico já rondava em minha cabeça. Os testes eram três: um texto previamente preparado por eles e que admitia um interlocutor, a leitura de um trecho dramático ou poético por mim escolhido e uma improvisação mímica sobre tema preestabelecido. Foi um trabalho exaustivo que durante vários dias ocupou mais de três horas. Mas, finalmente, chegamos a um resultado: escolhemos vinte jovens que a partir daquele momento passaram a fazer parte do Teatro Novo. Para evitar deserções e dar, desde o início, um caráter profissional ao trabalho das aulas, ficou combinado que os alunos receberiam uma ajuda de custo e uma refeição diária que a cozinha recém-organizada já preparava para todo o pessoal atuante. ",43

Com a intenção de atrair um novo público, e visando o lançamento do antigo Teatro República, agora com o nome de Teatro Novo, teve-se a idéia da realização de um festival de música popular. Para isso, Haroldo Costa foi contratado como apresentador e comentarista do evento.

\footnotetext{
${ }^{43}$ RATTO, Gianni.A Mochila do Mascate p. 127. Editora Hucitec. São Paulo. 1996
} 
Após terem realizado cuidadosamente todo o material gráfico do teatro, cometeram o primeiro erro na sua inauguração. Nos cartazes, em que foram divulgadas as atrações, constavam os nomes de todos os artistas, porém não havia menção à data e horário em que se apresentariam, fazendo crer ao público de que todos teriam participação em todos os dias, fato esse que causou tumulto. Porém, o problema foi contornado pela beleza das apresentações individuais realizadas, independente de ser aquele o artista que deveria ser apreciado no horário pretendido pelo espectador que ali comparecia.

A inauguração oficial do Teatro Novo se deu com a apresentação da Orquestra Sinfônica Brasileira além da presença da grande pianista Madalena Tagliaferro. Mais uma vez, um equívoco nos dizeres do programa distribuído fazia crer ao público que a programação da casa seria voltada para o mesmo tipo de espetáculo apresentado em sua inauguração.

No dia seguinte, estreou o espetáculo teatral Ralé, de Máximo Gorki, resultado do curso ministrado aos jovens atores. Foi um sucesso estrondoso. Apesar da pouca idade dos atores, eles não decepcionaram, mantendo durante toda a temporada a casa lotada. Um dos motivos da ótima repercussão foi o preço dos ingressos, acessível a todos, conforme Gianni havia solicitado a Paulo Ferraz, uma vez que os preços praticados por outros teatros não possibilitavam o acesso das classes menos favorecidas economicamente aos espetáculos teatrais. Resultado, as filas davam voltas nos quarteirão.

Continuando com o projeto desenvolvido, pensaram também em dar início a uma atividade editorial, que consistiria na publicação de uma revista de teatro, de alto nível, em três idiomas. Para dar início a mais esse projeto, com a colaboração do Correio da Manhã, editaram um pequeno volume in folio dedicado a Máximo Gorki, o autor do espetáculo, contando com a colaboração de artigos de Antônio Houaiss, Clarice Lispector, José Lino Grünwald, Otto Maria Carpeaux, Wlamir Ayala, e do próprio Gianni Ratto. 
E a dança? Bem, o grupo de dança apresentou-se também com grande sucesso, produzindo espetáculos que despertavam enorme interesse de seus admiradores e dos profissionais da área.

O público infantil não havia sido esquecido, uma vez que um elenco de adultos se apresentou também com grande êxito na adaptação de O Pequeno Príncipe (Le Petit Prince), de Antoine de Saint-Exupéry. A consagração da empreitada completou-se com a realização do bem sucedido Festival Nacional de Bonecos e Marionetes, o qual reuniu grupos entre os melhores do país.

Gianni sempre foi muito ligado à música, o que não surpreende o fato de, ainda pensando nas montagens teatrais, ter conseguido os direitos de montagem de uma saga do escritor chileno Pablo Neruda que encontrava-se de passagem pelo Brasil, e que era amigo da mãe de Tatiana Memória, a administradora do teatro para transformar futuramente num grande musical. O mesmo ele fez com seu amigo Millôr Fernandes, encomendando ao escritor um texto para a montagem de um musical sobre a Lapa do Rio de Janeiro. Estava, ainda, iniciando a difícil tradução de Ubu Rei (Ubu Roi), de Alfred Jarry, o que lhe tomava muito tempo, impedindo-o de acompanhar, como deveria os ensaios de balé, para os quais, não obstante, ainda desenhava os cenários. Mesmo assim, isso não impediu que se tornasse difícil sua relação com o coreógrafo da companhia, Arthur Mitchell.

Conforme havia planejado, o Teatro Novo tinha funcionamento exemplar, abrindo suas portas à partir das oito horas da manhã e fechando apenas a meia-noite (ou um pouco mais tarde). As atividades eram intensas, com seus cursos e espetáculos apresentados. Já estavam até em contatos com escolas e grupos do exterior para intercâmbios culturais e técnicos com o Brasil. Contatos com, por exemplo, Jacques Lecocq, na França, o Teatro de Praga, e o Piccolo, de Milão. Um dos artistas que aceitou o convite foi o coreógrafo e bailarino Merce Cunnigham, que apresentou com seu grupo diversos espetáculos no Teatro Novo.

O empreendimento estava, como esperado, dando certo e respondendo a todas as expectativas. Um trabalho sério, que pelos cálculos realizados começaria a dar lucros em três anos. Isso sem contar que os contratados do teatro tinham todas as vantagens 
trabalhistas de lei, como décimo-terceiro salário, seguro sobre acidentes, assistência médica permanente no próprio consultório do teatro, férias pagas, uma refeição por dia, além de outros benefícios, o que era difícil acontecer no Brasil naquela época, em se tratando da classe artística. Tudo realmente ia às mil maravilhas, mas é preciso lembrar que era o auge da ditadura militar no país e seus efeitos estavam por se apresentar também nesse novo templo da cultura. A notícia do primeiro "movimento" foi dada por um telefonema de Pamplona a Gianni contando que milícias enviadas pelo DOPS, armados de metralhadora, invadiram o teatro por suas duas entradas de acesso. No momento da invasão, havia na platéia cerca de uma dúzia de jovens, com idades entre dezoito e vinte e um anos participando de uma aula de comunicação, ministrada por um jornalista do Correio da Manhã. Na seqüência, seria a vez de Gianni Ratto ministrar sua aula. O diretor, avisado do incidente, correu, imediatamente para o local. Assim ele define o que aconteceu na ocasião:

"Desci correndo e me deparei horrorizado com nossos alunos: as mãos encostadas na parede direita da sala, as pernas afastadas, o corpo inclinado na mesma postura à qual são obrigados os delinqüentes. Pamplona e Tatiana estavam falando agitadíssimos com o glorioso comandante da operação, um sujeito atarracado, de axilas suadas, rosto avermelhado e cabelos de um loiro desbotado cortados curtinhos rente ao crânio. Fui oficial de exército e sei usar o tom do comando, mas só disse: "É minha hora; vou dar aula" e indiquei os meninos. Fui para o palco e, confesso, não esperava tanto: os jovens tão estupidamente humilhados vieram se sentar na minha frente. Comecei a falar e daí a pouco o próprio generalíssimo aproximou-se e, interrompendo-me no meio de uma palavra, afirmou magnanimamente: "Por hoje fica assim, mas da próxima vez...", acrescentando: “entenderam?”. E sendo que todo o mundo ficou calado, abaixando ou virando o rosto, congestionado ao da menina mais próxima. Alguns segundos depois, empertigado, reuniu seu exército e foi embora."

\footnotetext{
${ }^{44}$ RATTO, Gianni.A Mochila do Mascate p. 131 Editora Hucitec. São Paulo. 1996
} 
Horas após o acontecido, Gianni receberia um telefonema de Paulo Ferreira comunicando que, por decisão superior, o teatro estava definitivamente fechado e conseqüentemente, teriam interrompidas todas as suas atividades. Apesar disso, o empresário honrou todos os compromissos financeiros. Nunca se soube o motivo da intervenção no Teatro Novo, se o fato se deveu a interesses econômicos, uma vez que Paulo Ferraz era dono de estaleiros, ou apenas, e o mais comum, a alguma denúncia de supostas posturas esquerdistas praticada pela companhia.

A companhia de dança acabou por dissolver-se, e a maioria de seus bailarinos retornou ao Theatro Municipal. Os alunos de teatro, completamente perdidos diante do ocorrido, cercaram Gianni em busca de uma resposta, de um rumo para tomar, após a estúpida e brutal interrupção de seu aprendizado, e da montagem do segundo texto da casa, Ubu rei, pela truculência das forças militares. Com o intuito de manter o moral alto, e viva uma idéia, propôs a continuidade da montagem, mesmo que a princípio não dispusessem de recursos financeiros para montar o espetáculo. Foi dessa forma que viajou a São Paulo para tentar levantar junto a Comissão Estadual de Teatro, verba para a conclusão do empreendimento. O espetáculo tinha tudo para ser um sucesso, pois Gianni havia se debruçado com afinco sobre o texto de Jarry, tendo também estabelecido contato com a sociedade francesa responsável pelos trabalhos do autor. Illo Krugli, com quem já trabalhara, foi convidado para fazer os bonecos e marionetes, que deveriam também contracenar com os atores, além da confecção de máscaras, adereços e figurinos como forma de enriquecer a montagem.

A subvenção solicitada foi concedida, entretanto foram em busca de mais recursos para a realização do projeto, tendo Tatiana Memória ainda à frente da captação do montante necessário para sua estréia.

Os ensaios ainda aconteciam no Rio de Janeiro, mas Gianni novamente voltou a São Paulo à procura do teatro que os deveria receber para a temporada. Foi cogitado o SESC Anchieta, porém, recusado pelo diretor que via numa de suas cláusulas a necessidade de uma censura prévia, fato que posteriormente ele iria constatar ser apenas pró-forma. Optou-se, então, pelo Teatro Itália, gerido por seu amigo o Prof. Edoardo Bizzarri. A escolha configurou-se em um grande erro. Gianni Ratto não sabia que a administração do teatro era uma das mais duras e exigentes de São Paulo, o que fez com 
que Bizzarri realizasse verdadeiros malabarismos para que os artistas não fossem expulsos da casa de espetáculos. Mas expulsos por quê? Acontece que, como toda a instituição governamental, talvez até nos dias de hoje, o dinheiro solicitado ao Estado só seria disponibilizado após o término da temporada e, ainda assim, mediante a demonstração cabal dos anúncios de preços reduzidos, somando-se a isso o fracasso da bilheteria, apesar das ótimas críticas recebidas. "As inteligentes intenções de $\boldsymbol{U} \boldsymbol{b u} \mathbf{R e \boldsymbol { i }}$, de Jarry, sob a direção de Gianni Ratto e com fantoches de Illo e Pedro, não conseguiram comunicar-se com o público. ${ }^{45}$ Deve-se acrescentar ainda que, para o recebimento da subvenção, havia a necessidade de ser realizada uma temporada popular do espetáculo em um dos teatros da Prefeitura, o que prejudicou ainda mais a saúde financeira do grupo, uma vez que deveriam investir em mídia para atrair público para um teatro que não tinha, à época, qualquer tradição de espetáculos, como era o Teatro João Caetano. Assim, a trupe, ao final da temporada, voltou aliviada para o Rio de Janeiro, sobrando para Tatiana Memória o encargo de permanecer na cidade para receber o dinheiro subvencionado e, dessa forma, saldar todas as dívidas, que incluía o aluguel do Teatro Itália.

Apesar de tudo, o projeto do Teatro Novo foi o embrião de uma verdadeira escola cultural, um espaço que agregava todos os anseios artísticos do diretor, integrando cursos técnicos e artísticos, oferecendo oportunidade de conhecimento a toda a sociedade, mesmo àqueles menos favorecidos economicamente, mas que possuíam uma enorme ânsia de aprender. Uma escola de arte que seria um exemplo a ser seguido nas décadas por vir.

\footnotetext{
${ }^{45}$ MAGALDI, Sábato e VARGAS, Maria Thereza. Cem Anos de Teatro em São Paulo.Editora SENAC São Paulo. 2000.
} 


\section{La Strada - O caminho se faz ao andar.}

Apesar do revés pelo qual passou com a experiência do Teatro Novo, Gianni não esmoreceu, pois tinha muito ainda por fazer: cenários, iluminação, aulas e seminários, além, é claro, de direções.

Em 1971, dirigiu para Maurício e Beatriz Segall, pelo Teatro São Pedro, O Casamento de Fígaro (Le Marriage de Figaro), de Beaumarchais, compondo um elenco misto entre atores negros e brancos; e em 1972, assinou a direção de A Grande Imprecação Diante dos Muros da Cidade, de Tankred Dorst.

Gota D’Água, de Paulo Pontes e Chico Buarque, é encenada pelo diretor em 1975. Mais um marco para o teatro nacional, a montagem está associada ao teatro de resistência que pretendia materializar dois objetivos de uma só vez: retratar de forma contundente a realidade brasileira, apelando para uma fábula grega universalmente reconhecida (Medéia) e, igualmente, criar um grande espetáculo musicado, uma tônica da produção contemporânea, destacando a brilhante atuação de Bibi Ferreira à frente do elenco.

Encenou O Grande Amor de Nossas Vidas, de Consuelo de Castro, produzida em São Paulo, em 1979 e, no Rio, em 1980, texto que apresenta um pioneiro estudo dramático sobre os ranços reacionários e autoritários da pequena classe média.

A Venerável Madame Goneau, um dos bons textos de João Bethencourt, é encenada no Teatro Paiol, em 1981 e, em 1982, no Teatro Clara Nunes, no Rio de Janeiro, A Eterna Luta Entre o Homem e a Mulher, de Millôr Fernandes. Pela terceira vez, em 1984, encenou Com a Pulga Atrás da Orelha, de Georges Feydeau. Realizou uma versão de Drácula, de Hamilton Deanne e Hohn Balderston, com Sergio Mamberti, no ano de 1986.

É preciso lembrar que Gianni Ratto foi, também, um dos cenógrafos mais conceituados com extenso currículo de participações em espetáculos importantes, arrebatando uma série de prêmios nesta categoria, bem como na de iluminador. Dentre os diretores e grupos com quem colaborou estão: Ruggero Jacobbi, em Mirandolina, de 
Carlo Goldoni, pelo Teatro Popular de Arte, em 1955; Ziembinski, em O Santo e a Porca, de Ariano Suassuna e Jornada de um Longo Dia para Dentro da Noite (Long Day's Journey Into Night), de Eugene O’Neill, ambos em 1958, como também César e Cleópatra, de Bernard Shaw, em 1963, todos pelo Teatro Cacilda Becker; Boca de Ouro, de Nelson Rodrigues, pela Companhia Brasileira de Comédia, em 1960; O Santo Inquérito, de Dias Gomes, em 1966; Augusto Boal e o Teatro de Arena, em A Dança dos Toreadores (La Valse des Toréadors), de Jean Anouilh, em 1958; Ivan de Albuquerque, no Teatro do Rio, em Diário de Um Louco, de Nicolai Gogol, em 1964; João das Neves, com o Teatro Opinião em A Saída, Onde Fica a Saída?, de Ferreira Gullar, em 1967; Paulo Afonso Grisolli, em Por Mares Nunca Dantes Navegados, de Paulo Afonso Grisolli e Tite de Lemos, em 1972; Fernando Peixoto, em Franck V, de Friedrich Dürrenmatt, em 1973, e Caminho de Volta, de Consuelo de Castro, no mesmo ano. Ponto de Partida, de Guarnieri, em 1976, e Paulo José, em Murro em Ponta de Faca, de Augusto Boal, em 1978, os três últimos com a Companhia Othon Bastos Produções Artísticas. O diretor para quem mais cenografou foi Flávio Rangel, com uma contribuição em mais de dez espetáculos, dentre eles: Abelardo e Heloísa (1971), de Ronald Millar, A Capital Federal, de Arthur Azevedo (1972), Dr. Fausto da Silva, de Paulo Pontes (1973), Pippin, de Roger O.Hirson e Stephen Schwarts (1974), Mumú, A Vaca Metafísica, de Marcílio Moraes (1975), O Rei de Ramos (1979) e Vargas (1983), ambos de Dias Gomes, Piaf, de Pam Gems (1983), Freud, No Distante País das Almas, de Henry Denker (1984), Negócios de Estado, de Louis Verneuil (1984), Cyrano de Bergerac, de Edmond Rostand (1986), Ladrão Que Rouba Ladrão, de Dario Fo (1987), O Amante de Madame Vidal, de Louis Verneuil, com tradução de Millôr Fernandes (1987), Uma Ilha Para Três, de André Roussin (1990), Lisístrata, de Aristófanes, e Senhoritas Q.D., de Cristina Bueno e Inês Viana, ambas em 1992. Será em 1993 que Gianni dirigirá um de seus maiores sucessos dos últimos anos, Porca Miséria, de Jandira Martini e Marcos Caruso. O espetáculo foi muito importante, principalmente para a situação econômica do diretor, além de fazer com que voltassem os olhos para sua obra. O espetáculo contava em seu elenco, além da presença dos autores do texto, com a impagável, e memorável, atuação da consagrada atriz Miriam Muniz. Neste mesmo ano, ele ainda dirigiria uma versão reduzida para a EAD de seu grande sucesso dos anos 60, O Mambembe, de Arthur Azevedo, e também o difícil espetáculo As Bruxas, de Santiago Moncada, com tradução de Marcos Caruso. Em 1994, tem vez os espetáculos A Última Carta, de Nicola Martin, com tradução de 
Edla Van Steen, e o belíssimo espetáculo Morus e Seu Carrasco, de Renato Gabrielli, com tradução do próprio diretor. Seu último trabalho como diretor será o texto de seu amigo Aimar Labaki, Vermouth, em 1998.

Em 2001, exerceu a função de curador do Formação de Público, projeto da Secretaria Municipal de Cultura de São Paulo, que visava oferecer um panorama da dramaturgia nacional para o público leigo, com a função de selecionar os textos e diretores a serem encenados.

No entanto, será na atividade de iluminador que seu nome retornará com êxito em 2002, no espetáculo Novas Diretrizes em Tempos de Paz, de Bosco Brasil, e dirigida por Ariela Goldman. Cabe destacar esse trabalho dentro do vasto currículo de direção de Gianni, apenas por um comentário de Aimar Labaki sobre o espetáculo:

“...uma obra prima do teatro brasileiro nos últimos dez anos é Novas Diretrizes nos Tempos de Paz. Nessa obra prima você tem um texto que parece esplendoroso, um texto que vai ficar, um cânone. Eu me emociono ao me lembrar dele. Que tinha uma encenação extremamente inteligente da Ariela, tinha o cenário e a luz do Gianni, tinha os atores, o Dan que estava num momento inspirado, todos os outros atores que passaram pelo outro papel, o Jairo, o Paschoal, o Toni Ramos, todos os elementos eram maravilhosos. Só que se você pensar nesses elementos, esse era um espetáculo do Gianni Ratto. Ele é uma súmula das opções do Gianni. Mas a direção da Ariela poderia ser uma direção do Gianni. O texto do Bosco segue todas as opções estéticas e éticas do Gianni. Então, esse espetáculo, que é o melhor que a gente fez nos últimos dez anos, é um espetáculo do Gianni Ratto, ainda que ele não esteja ali. Até está, quer dizer porque foi o ano em que ele ganhou um Shell especial. Ele foi reconhecido como cenógrafo e iluminador disso. Mas a importância não é essa, a importância maior é que os valores do Gianni estavam ali. Aquilo que, repito, é o melhor que a gente fez nos últimos dez anos, é um 
espetáculo de Gianni Ratto. E de uma brasilidade desesperada, em busca de uma identidade,. ${ }^{46}$

Entre suas produções literárias podemos citar os livros Antitratado de Cenografia, em que discorre sobre aspectos técnicos e evolutivos da arte cenográfica, A Mochila do Mascate, livre biografia sobre sua vida e obra, além de reflexões sobre artes e artistas que cercaram a sua trajetória profissional e, mais recentemente, Hipocritando, no qual discorre sobre a profissão do ator. Ultimamente enveredou também para a escrita de contos, tendo publicado Crônicas Improváveis e Noturnos: E Outros Contos Fantásticos. Antes de falecer, desenvolvia um projeto de escrita de um livro sobre o arquiteto italiano Mario Labò, o qual não foi por ele finalizado.

Gianni Ratto foi um completo homem de teatro. Integrante da primeira geração de encenadores no Brasil. Assim como Ziembinski, foi um estrangeiro que se tornou indiscutivelmente brasileiro, configurando-se o italiano que mais contribuiu, numérica e ideologicamente para a evolução do teatro nacional. Sua importância é constatada nas palavras de Sábato Magaldi, ao prefaciar seu livro de memórias A Mochila do Mascate:

"Ninguém, como ele, se associou de forma tão consciente $e$ conseqüente à dramaturgia brasileira. (...) Gianni lançou $\boldsymbol{A}$ Moratória, de Jorge Andrade, um ano após sua chegada a São Paulo. E, a partir daí, estabeleceu como meta preponderante a valorização do nosso autor, base de uma desejada identidade cênica. (...) Seguiram-se várias montagens, em épocas diversas, que tiveram, ao lado do mérito artístico, o de revelar aspectos fundamentais da nossa realidade. (...) Todas elas imbuídas do propósito de servir bem ao autor, colaborando de forma decisiva na construção do nosso teatro. Só essas virtudes, sem necessidade de mencionar nada mais, asseguram para Gianni Ratto o crédito de uma imensa gratidão do País". 47

\footnotetext{
${ }^{46}$ Entrevista concedida por Aimar Labaki ao autor da dissertação, em setembro de 2006.

${ }^{47}$ RATTO, Gianni. A Mochila do Mascate prefácio. Ed. Hucitec. São Paulo. 1996.
} 
Essa opinião é corroborada pelas palavras de Aimar Labaki, crítico, dramaturgo, e amigo de Gianni:

"O Sábato fez um programa que era entrevistando ele (Gianni Ratto). Estavam Kalma Murtinho, eu e Eduardo Tolentino e ao final o Sábato disse uma coisa que eu nunca tinha pensado. Ele disse: "Olha, nenhum diretor, brasileiro ou não, foi tão importante para a dramaturgia brasileira quanto o Gianni. Basta você pensar que Jorge Andrade nasceu pelas mãos dele. Décio de Almeida Prado apresentou o texto de um aluno dele da EAD, que era o Jorge Andrade e falou com o Gianni. O Gianni convenceu o Sandro (Sandro Pollonio) e a Maria (Maria Della Costa) a fazerem, para Fernanda (Fernanda Montenegro) fazer sua primeira protagonista, Jorge Andrade. Arthur Azevedo era motivo de deboche, era uma cariocada. Depois da montagem do Mambembe, entrou pra lista dos grandes autores brasileiros, e todo mundo reverencia, e monta e não sei o quê. Trabalhou com Guarnieri, trabalhou com Vianinha, Se Correr o Bicho Pega, se Ficar o Bicho Come, foi feito ali; montou Gota d'Água, naquele momento da ditadura, e aí Sábato, na fala dele começou a enumerar, e terminou dizendo, e termina com a nova geração que foi Aimar Labaki." Isso me deu uma sensação de pertencer a uma tradição, que é uma coisa pouco costumeira no Brasil. No Brasil é tudo geração espontânea. E na hora me emocionou muito. E me deu consciência da importância do Gianni para a dramaturgia brasileira. Com quem você falar que trabalhou com ele como diretor, a tônica é essa: que ele era muito bravo, que ele era muito trabalhador, e a preocupação dele era texto, e ator. É óbvio que, como grande cenógrafo que era, ele tinha soluções visuais pro espetáculo que eram muito boas. Então, não é dizer que como diretor ele tinha uma deficiência do ponto de vista da organização da 
cena. Mentira, ele organizava muito bem. E, por opção, fazia com que esses elementos estivessem subordinados ao ator e ao texto." 48

Cabeça de uma geração, atuante em todos os períodos desde a sua chegada ao Brasil, na década de 50, Gianni Ratto foi um dos poucos encenadores que acumulou função, cenografando para suas próprias montagens, como também para outros diretores, realizando belíssimas iluminações, sendo bem sucedido em todas as categorias. Nascido no começo do século XX, continuou ativo e atuante até o fím de sua vida. Sábio e generoso para com os mais novos, conceituado e respeitadíssimo pelos mais velhos.

Mais do que um homem de teatro, Gianni Ratto foi uma verdadeira lição de profissionalismo, ética, humildade, generosidade e amor à arte, principalmente à arte de representar.

\footnotetext{
${ }^{48}$ Entrevista concedida por Aimar Labaki ao autor da dissertação, em setembro de 2006.
} 


\title{
CAPÍTULO III
}

\section{QUATRO FORMAS DE AMAR ou O AMOR EM QUATRO TEMPOS}

\begin{abstract}
"O espaço vazio do palco não é um lugar inerte, morto ou adormecido que seja. Um palco vazio é comparável a uma mulher, a um homem, a uma criança à espera de um ato de amor. Amor em todos os sentidos, desde o místico até o sensual, sempre conduzindo a um orgasmo, a uma catarse resultante de um encontro."
\end{abstract}

Gianni Ratto

Gianni Ratto, antes de ser um homem de teatro, era um ser humano que amava incondicionalmente a vida. Esse seu amor, essa sua paixão, ele procurava externar através de sua profissão. Seus espetáculos eram o reflexo de seus questionamentos internos, que, dentro de seu ecletismo, e da não preocupação de se ater a um determinado tipo de espetáculo, a um determinado autor, ou gênero teatral espelhavam a riqueza da diversidade humana. Seu compromisso era com a qualidade, com a integridade da profissão e com o prazer propiciado aos envolvidos no projeto e aos espectadores. Seus espetáculos primavam pela seriedade com que eram tratados, a forma artesanal com que todos os elementos que os envolviam eram cuidados para resultarem num produto único, nascido desse amor coletivo.

Essa sua dedicação poderia ser demonstrada com inúmeros espetáculos do diretor, porém foram selecionados três deles que, de acordo com suas características, configuraram-se fundamentais para a história do teatro brasileiro e seu desenvolvimento.

Com O Canto da Cotovia (L'Alouette), de Jean Anouilh, ele traz uma renovação das montagens que, até então, não se praticavam no país, quer no aspecto de estruturação do espetáculo, quer na sua encenação.

A Moratória, do autor brasileiro estreante à época, Jorge de Andrade, lançou uma nova luz à dramaturgia brasileira. Questionando a importância de seu desenvolvimento.

O Mambembe, de Arthur Azevedo, propiciou a revalorização desse importante autor brasileiro, que não era valorizado, bem como despertou o olhar do público para espetáculos teatrais que trabalhassem, harmoniosamente com a música, toda a brasilidade de nossos costumes e paixões, celebrando de forma saudável $\mathrm{o}$ nacionalismo. 
Bem, resta agora abrir a cortina e deixar o sol entrar, ou melhor, permitir que a serragem do teatro o envolva de emoções.

\section{Ben Venutto!!!}

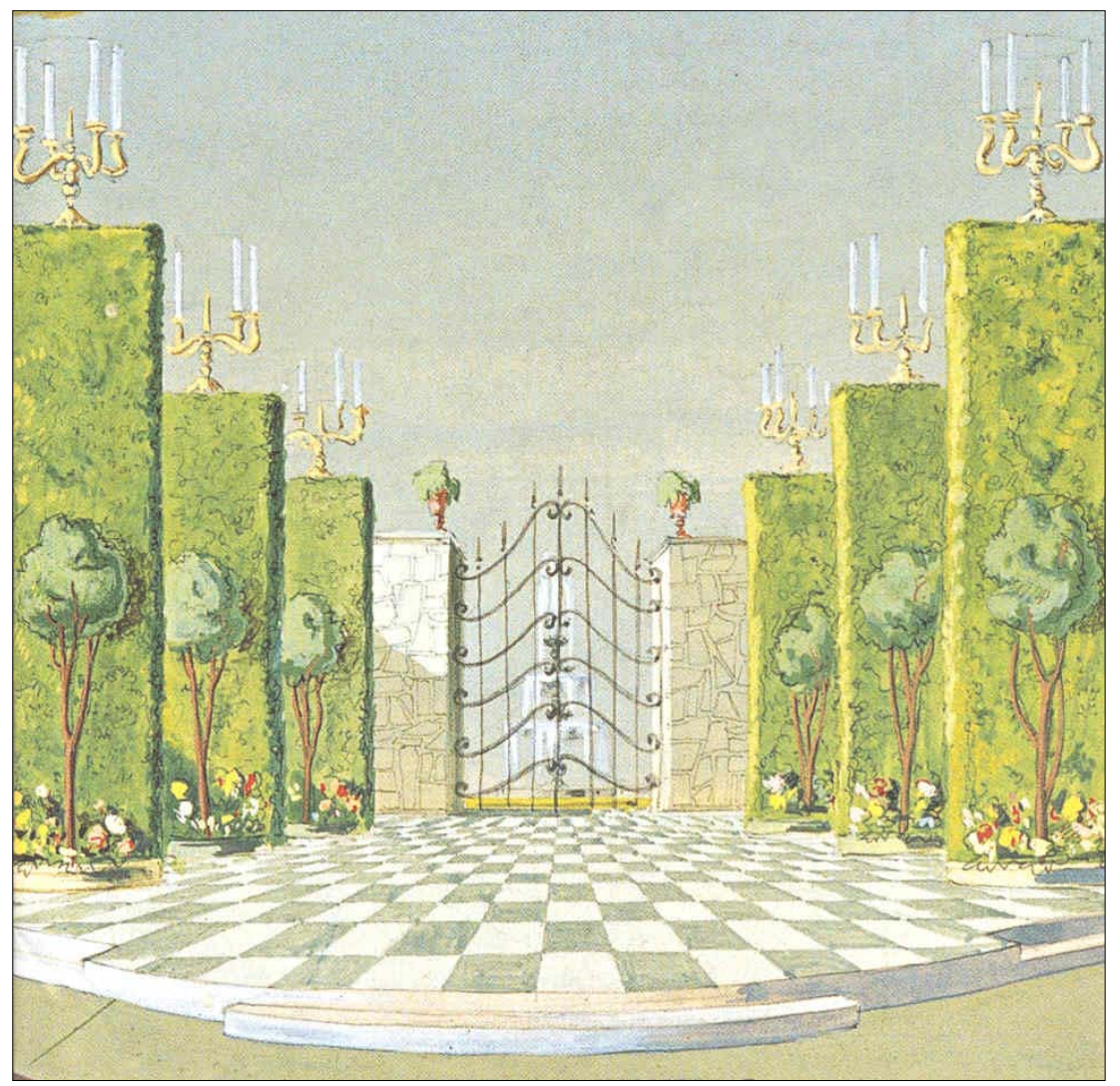

Giardino Delizioso

Cenário da ópera "La Cecchina Ossia La Buona Figliola" de Niccoló Piccini - Ato I - cena I. Desenho de Gianni Ratto - Teatro Alla Scalla, 1951. 


\title{
O Canto da Cotovia: $O$ amor pela pátria (ou pela religião).
}

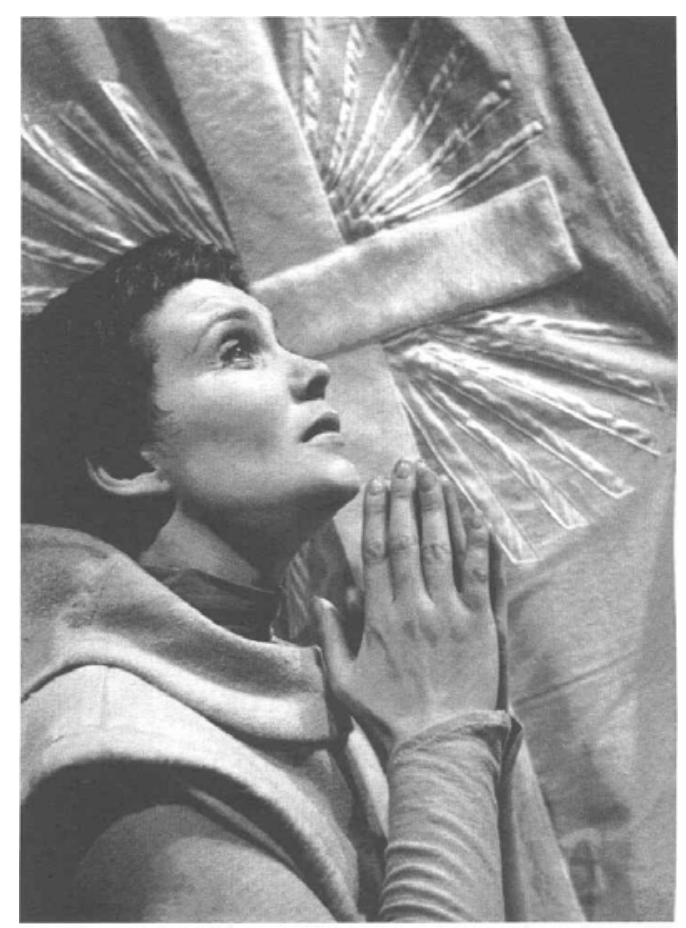

\author{
Maria Della Costa \\ O Canto da Cotovia - 1954
}

\section{O autor}

Jean Anouilh nasceu em Bordeaux, França, no dia 23 de junho de 1910. Filho de um alfaiate e uma professora de piano e musicista, talvez seja o autor mais representativo de sua geração.

Aos 19 anos de idade, torna-se secretário do grande diretor de teatro Louis Jouvet, no Théâtre des Champs-Élysées, em Paris, trabalhando, também, durante dois anos numa agência de publicidade com Jacques Prévert.

Sua primeira peça, uma farsa, será escrita em 1929 com o nome de Humulus, Le Muet (Humulus, o Mudo). Mas será somente em 1932 que escreverá sua primeira verdadeira peça teatral, L'Hermine (O Arminho). Nessa ocasião, ele decide viver apenas da escrita, porém o início de sua carreira será bastante duro.

Durante a ocupação alemã na França ele continua a escrever, não tomando qualquer posição partidária, nem como colaboracionista e nem pela resistência. No entanto ele escreve artigos sem qualquer teor político no jornal colaboracionista Je suis partout, pelo qual será futuramente criticado. Algumas pessoas gostariam que seu nome constasse da lista negra do final da Segunda Guerra, mas ninguém tinha nada a provar contra ele. 
Antígone, sua mais famosa peça, foi escrita em 1942, sendo encenada pela primeira vez no ano de 1944, no Théatre de l'Atelier, com direção, cenário e figurinos de André Barsacq. Todavia é mal recebida pelo público, fazendo com que autor e diretor tivessem se arrependido de sua montagem, dizendo que havia sido uma verdadeira catástrofe. A crítica, no entanto se divide afirmando que a peça possuía uma estranha ressonância, uma certa ambigüidade. Numa certa noite alguns panfletos da Resistência, clandestinamente distribuídos, surpreendem os espectadores, pois acusava o autor de colaboracionista.

A resposta a essa acusação viria num texto, posteriormente publicado com o intuito de salvar o escritor colaboracionista Robert Brasillach (redator-chefe de Je suis partout, durante a Ocupação), condenado à morte em fevereiro de 1945. Ele diz : « Eu nunca, nem mesmo de longe, simpatizei com os nazistas e seus tristes cúmplices, mas nutro uma certa compaixão pelos vencidos e refuto os excessos nos julgamentos. »

Anouilh, com seu teatro, se propôs a criar uma atmosfera poética cheia de situações livremente imaginadas, míticas ou cheias de paradoxos, onde se movem personagens de alma desiludida. O tema único desenvolvido por Anouilh em suas peças, com argumentos variados, foi a oposição irredutível entre a pureza e a juventude intransigente, limpa, apesar das manchas acidentais, e a sociedade hipócrita e corrompida que aceita as convenções mais degradantes.

A derrota da pureza, que se nega a se adaptar é a conclusão inevitável a que se chega. Seu primeiro êxito ocorre com Le Voyageur Sans Bagages (O Viajante Sem Bagagem), em 1937, e, a partir de então, não para de produzir obras renovadoras da cena, sobriamente trágicas, intimamente líricas, como La Sauvage (A Selvagem), Eurydice, ambas de 1942, e L'Alouette (O Canto da Cotovia), em 1953.

Sua obra Antígone, escrita em 1942, coberta por um disfarce da dramaturgia clássica grega, narra o poema da resistência e da tirania na Paris ocupada da Segunda Guerra. Outras obras importantes do autor também merecem ser citadas, como: Le Bal de Voleurs (O Baile dos Ladrões), de 1932, L'invitation au Château (Convite ao Castelo), de 1950, La Valse des Toréadors (A Valsa dos Toreadores), de 1951, Thomas Beckett, 1959, Cher Antoine (Querido Antoine), 1969, Le directeur de l'Opéra (O diretor do Ópera), 1972, Le Scénario (O Roteiro), 1976, e La Culotte (A Calcinha), de 1978. O próprio autor dividiu sua produção em peças negras, peças rosas, peças brilhantes e peças cruéis. Todas elas nostálgicas e pessimistas. 


\begin{abstract}
A história
O Canto da Cotovia é a história da mártir Joana D’Arc durante seu julgamento, no qual deve se defender de todas as acusações que pesam sobre ela. Joana tenta convencer o promotor e todo o povo de sua inocência. Sua família está presente e Joana é instada a contar sua história a partir das visões que têm, e das vozes que escuta junto a Árvore das Fadas, onde ela fala com o arcanjo São Miguel. Relata ela que recebeu a incumbência de restituir a França a seu rei, expulsando os ingleses, seus inimigos, do território francês. O promotor a chama de orgulhosa e quer que ela realmente diga a verdade, abandonando toda a superstição. No entanto, ela prossegue contando suas conversas com os santos. Toda sua família acredita que ela mente. Seu pai crê que a jovem tenha um amante, e este seja o motivo de ter permanecido tanto tempo na floresta. Ele também não acredita mais na virgindade de sua filha. A seus olhos ela não é mais pura. Ele fica com raiva e sua família zangada com ela, vira-lhe as costas, todos envergonhados em virtude da situação pela qual estão expostos.
\end{abstract}

Apesar de toda a pressão, ela não cede e continua a afirmar o que diz. Todos os homens envolvidos no processo, Cauchon, o promotor, o inquisidor e Warwick, desejam que ela se declare culpada por heresia. Eles sabem que ela é religiosa e uma boa cristã, devendo, portanto, permanecer nos braços da Igreja, renunciando a todas essas mentiras. Dizem-lhe que deve trocar suas vestes, uma vez que está usando roupas masculinas, instando-a de uma vez por todas a confessar que é uma herege.

Ao final da peça, ela recebe a pena de morte, então é colocada numa fogueira para ser queimada. Beaudricourt, o homem que lhe deu as roupas masculinas a fim de falar com o Delfin, surge para salvá-la.

\title{
O texto e a montagem
}

Maria Della Costa e seu marido, Sandro Polloni, quando foram até Milão convidar Gianni Ratto para que dirigisse uma peça que inauguraria seu teatro em São Paulo, não tinham ainda a idéia do que montar. Dessa forma, solicitaram ao diretor que procurasse um texto que, também se adequasse à atriz e tivesse um apelo público. Após 
troca de correspondências finalmente Gianni Ratto chega a São Paulo e fica hospedado na casa que Maria Della Costa dividia com o marido e a sogra, uma simpática italiana também de Milão, no Tremembé. Gianni traz consigo a peça debaixo do braço, entregando-a ao casal.

Inicialmente, Sandro ficou relutante pois, como empresário, acreditava, já naquela época, que uma comédia surtiria mais efeito junto ao público do que um drama, a história trágica de uma mártir como Joana D’Arc, para a inauguração de um teatro. Mas concordou com a sua leitura. A peça foi traduzida e os dois ficaram deslumbrados com o texto, de uma beleza ímpar. Maria relata, nas palavras de Gianni, um dos motivos da escolha desse texto:

“...eu vi a figura da Maria - depois que ele me falou - eu vi a figura da Maria, e na conversa da Maria, no olhar da Maria, e na candura - ele gostava muito de mim na candura da Maria, no rosto da Maria, eu tinha certeza, e tenho certeza que ela vai fazer uma grande Joana. "49

Gianni Ratto encontrava-se muito animado com a nova perspectiva de vida e, principalmente, com o empenho daqueles dois jovens artistas. Via seu poder de luta, sua vontade de querer ir em frente, na busca de novos desafios, com o objetivo de construir um teatro próprio, sede de sua companhia.

Decidida a peça, começaram o processo de seleção de elenco, alguns atores já conhecidos, outros não, além de profissionais com larga experiência, como Eugênio Kusnet, o qual viria a trazer alguns problemas para a montagem, como nos conta a atriz:

"Mas começaram os ensaios e aí começou uma pequena guerra. Dos atores e do Gianni, do Eugênio Kusnet, que era diretor também, e que também era professor disse assim, Como? Eu estou aqui no Brasil, sou grande professor e diretor e eles vão e contratam um diretor que não fala uma palavra de português. Como é que ele vai ensinar os nossos atores? Ai começou aquele ciúme. Ai ele começou a

\footnotetext{
${ }^{49}$ Entrevista concedida por Maria Della Costa ao autor da dissertação, em 19 de janeiro de 2007.
} 
introduzir, o Eugènio Kusnet, aquele ciúme, aquela mágoa, aquele negócio todo nos outros atores. Porque os atores ficavam nervosos porque não entendiam o Gianni Ratto que falava muito, entende? Era mais na mímica, porque ele estava ainda aprendendo o português também, ele tinha muita força de vontade, o Gianni. Aí começou uma guerra, sabe, surda, muda, e aí começou a se espalhar e o Gianni Ratto começou a se sentir mal. Começou a se sentir mal e não conseguia dirigir, muito emotivo que ele era. Ai ele chamou o Sandro e a mim num canto e começou a chorar. Eu, pela primeira vez, vi um homem chorando desse jeito. Ele disse: Olha, estou realmente chorando porque eu quero trabalhar, eu vim com esse propósito, vocês me chamaram pra eu criar uma coisa nova e eu estou tentando, mas eu estou sentindo que a barra está pesada pra mim aqui, eu não posso dirigir assim, nessas condições. E eu disse: Não, eu vou, eu como mulher, como dona da companhia e como amiga dos meus atores, porque eu nunca fui patroa. Ai eu comecei a chamar um por um e diss: Olha o nosso propósito é esse. Chamei o Eugênio Kusnet:: Eugênio você terá outras direções também, você vai ajudar em outras coisas, mas aqui nós temos que inaugurar o teatro com uma coisa nova. É um diretor que vem de fora, da Itália, grandes promoções nos jornais, nos livros, e tudo. Ele foi se acalmando, se acalmando, o elenco também foi se acalmando, e a gente entrou num ritmo de trabalho maravilhoso, e de criatividade, de criação".

Maria Della Costa confirma que apesar da internacional fama de cenógrafo de Gianni Ratto, ele demonstrou com sua realização que a cenografia deveria servir ao espetáculo, servir aos atores, servir ao texto, servir ao autor. Na inauguração do teatro, um projeto de Niemeyer e Lúcio Costa, após sua apresentação, elogiou-se muito o cenário, mas como componente intrínseco do espetáculo.

"Eles não tinham muita visão do Gianni como diretor, como cenógrafo sim. Então, todos eles pensavam: bom, ele vai se esbaldar no cenário, ele é cenógrafo, então ele vai querer aparecer porque 
geralmente é assim. Os cenógrafos fazem a criatividade, eles querem aparecer, é justo, tão ali pra fazer. E ele, então, a crítica toda espera a abertura do pano pra ver. E quando abriu o velário, o pano de boca, foi aquela coisa maravilhosa de cenário. Que era de uma simplicidade! Sem iluminação, e no final, quando acendiam as luzes atrás dos vitrais, que formava aquele colorido todo dos vitrais, era uma catedral, uma igreja mesmo. O público levantava e aplaudia aquilo, porque era uma coisa linda. Ele fez aquilo com papel celofane por de trás, as cores, tudo recortado, tudo. Então, o cenário foi de uma sobriedade que deu lugar ao texto, o texto se sobressaiu. Não é aquelas coisas que o cenógrafo faz e mata o texto. Como dizia Itália Fausta: Na minha época a gente até fazia teatro com uma rotunda, porque a palavra estava em primeiro lugar, o autor. Depois, veio a evolução. Mas o Gianni Ratto cuidou muito disso e fez o cenário e a crítica falou... O Décio de Almeida Prado colocou o espetáculo nas alturas, todos, todos, todos, toda a crítica. ${ }^{, 50}$

Mais uma vez mostra-se a preocupação do diretor, com a valorização do texto, do ator, para que o público se atenha fundamentalmente à mensagem que será recebida do autor através dos atores da representação.

Esta constatação, com respeito à cenografia e o texto, pode ser conferida na crítica de Décio de Almeida Prado sobre a estréia do espetáculo:

“Gianni Ratto, esplêndido cenógrafo como é, não cometeu o erro tão comum de trazer o cenário para o primeiro plano. Aproveitandose habilmente, da altura do palco, imaginou uma série de plataformas ligadas entre si por escadas. Criou assim, não um lugar histórico determinado, mas um espaço cênico concebido especialmente para fazer funcionar a peça, permitindo-lhe a maior mobilidade plástica e cênica. É um cenário do tipo de Arlequim, Servidor de Dois Amos, ou de Eletra, que vimos recentemente no Piccolo Teatro, no sentido de

\footnotetext{
${ }^{50}$ Entrevista concedida por Maria Della Costa ao autor da dissertação, em 19 de janeiro de 2007.
} 
não querer competir em importância com o texto, servindo-lhe antes de suporte. Somente que a solução, para a peça de Anouilh, é mais rica arquitetonicamente, dada a variedade de ambientes requeridos pelo texto, desenvolvendo-se tanto verticalmente quanto horizontalmente. ",51

E continua,

"Ainda de outra forma vive o cenário. Do ponto de vista dramático dá aos atores uma extraordinária riqueza de marcações. As personagens entram e saem livremente, sobem e descem, dispersam-se ou concentram-se, transformando o palco, por esses simples expedientes, numa sala de trono ou num tribunal da Igreja, numa casa rústica ou na catedral de Rheims. O resultado é uma constante alegria para os olhos, um espetáculo de extraordinária beleza plástica, um dos mais belos que São Paulo já viu, não se excetuando os das melhores companhias estrangeiras. ",52

Isto pode ser verificado também numa afirmação de Silvio D’Amico sobre a função do diretor. Diz ele:

“...é necessária a presença de um artista novo: de um que não esteja dentro do espetáculo, mas fora dele; que materialmente, ou pelo menos idealmente, não pertença à categoria dos atores, não tenha como único ou principal objetivo mostrar sua capacidade ou sua vaidade; mas, dotado de uma inteligência e de uma cultura ad hoc tenha por supremo ideal o equilibrio, as proporções, a harmonia, e, é claro, a fidelidade do conjunto. ",53

\footnotetext{
${ }^{51}$ PRADO, Décio de Almeida. “Apresentação do Teatro Brasileiro Moderno”. São Paulo.Ed. Perspectiva. 2001. p. 230

${ }_{52}^{2001 .}$ Id.

${ }^{53}$ Silvio D’Amico, “La Regia Teatrale, Roma, Ângelo Belardetti, 1947, p. 14.
} 
A crítica elogia de forma uniforme o espetáculo, que levou praticamente todos os prêmios daquele ano em que se celebrava o quarto centenário da cidade de São Paulo.

Ainda com relação à direção de Gianni Ratto, nos diz Décio de Almeida Prado:

"No que diz respeito à direção dos atores, Gianni Ratto obteve igualmente ótimos resultados. Tomando em mãos um elenco heterogêneo e recém-formado, constituído por veteranos e principiantes, profissionais e amadores, vindo das experiências teatrais as mais diversas, conseguiu, em apenas dois ou três meses, incutir-lhe muita homogeneidade, baseada principalmente na discrição e no bom gosto. Ninguém representa demais, nem de menos, ninguém procura a ênfase que ainda hoje se associa, às vezes, erradamente, ao gênero histórico. A representação é simples, natural, sóbria. Poderá haver pontos mais altos ou mais baixos, mas nenhum que destoe verdadeiramente (exceto a Rainha de França, que parece pisar o palco pela primeira vez, não sendo mencionada no programa). ",54

Em seu depoimento, Maria Della Costa reafirma que Gianni Ratto era um diretor de textos e de atores. De forma geral, a dedicação com o texto e com o ator eram muito importantes, fundamentais mesmo, uma vez que os espetáculos duravam duas horas, ou mais, sendo as representações realizadas de terça a domingo, realizando-se duas sessões nos finais de semana. Quanto ao tempo de ensaio ela completa:

“Era outra coisa. Nós ensaiávamos das duas da tarde às oito, nove. Não tinha horário para acabar. A gente comia até sanduíche dentro do teatro, e tocava até uma hora, duas horas da manhã. "55

\footnotetext{
${ }^{54}$ PRADO, Décio de Almeida. "Apresentação do Teatro Brasileiro Moderno" p.230. Ed. Perspectiva. São Paulo. 2001.

${ }^{55}$ Entrevista concedida por Maria Della Costa ao autor da dissertação, em 19 de janeiro de 2007.
} 
A liberdade que ele dava para a construção da personagem, o modo que via a sua construção, era bem diversa daquela realizada por outros diretores da época, como ela mesma relata:

"O exercício para ele era a repetição. Era o timing. Repete, repete, repete. Descansa. Toma água, toma um café. Agora começa de novo. Senta um pouco. Raciocina o que você está fazendo. Leia. Pega a peça para mim de novo e leia o texto, desse texto que você está fazendo. Ai ele descia e dizia assim: Vai Maria, ou a um outro ator qualquer, e a gente fazia com ele a repetição, mas não feito papagaio. Era entender o que se estava lendo. Porque às vezes o nervosismo de querer fazer na prática...mas a teoria é uma coisa importante também, de você também entender. É aquilo que eu falei, o ator vai e faz mas depois fica naquilo. E ele tinha esse tipo de exercício, de leitura. Muita leitura, muito entendimento. Ele dizia: Maria o que que você acha que é essa personagem, como é que você a vê?, no inicio dos trabalhos na mesa. Ele deixava você explanar dentro da sua maneira de ser. Porque ele não impunha, ele não dizia assim, não era um diretor do tipo do Ziembinsky. O Ziembinsky era um grande diretor, mas ele dava tudo, inclusive as marcações, as inflexões dele e quando você levava, ia ver no palco, era um pouco Ziembinsky todo mundo. "56

Continuando a falar do espetáculo, Ruggero Jacobbi enaltece também em sua crítica a atuação do diretor e sua preocupação com a harmonia do espetáculo como um todo. Ele escreve:

"Gianni Ratto escolheu muito inteligentemente este Canto da Cotovia para sua estréia como diretor. A peça, com efeito, permitethe explorar ao máximo a condição privilegiada em que ele se encontra de ser ao mesmo tempo o orientador da representação e o

${ }^{56}$ Id. 
responsável pelos valores plásticos do espetáculo. A concepção de Anouilh é, em si mesma, uma arrumação constante das pessoas e quadros, visando mais a criação de grupos do que o movimento; bem se compreende como um especialista em artes figurativas se encontre à vontade neste terreno, desenvolvendo os pontos de partida oferecidos pelo autor com mais liberdade e riqueza, de acordo com o próprio gosto pessoal. Isso tudo, porém, ainda diz respeito ao aspecto externo da encenação. Há outro ponto em que a estrutura (de oratório e rádio-drama) da peça de Anouilh favorece um diretor estreante, obrigando-o a fazer um teste sobre si mesmo, no que diz respeito a sua tarefa principal, ou seja, a direção de atores. Quero dizer que o fato de estar livre dos minuciosos compromissos da marcação naturalista e, ao mesmo tempo do espetacular, como massa, dinamismo, eloqüência - o fato, em suma, de fazer um espetáculo que está a igual distância, seja da peça de observação e de enredo, como da peça de linha clássica e declamatória -, representa uma ocasião única para o encenador trabalhar os seus intérpretes com profundidade, um por um, inclusive tirando partido da ausência quase total de diálogos de ritmo curto ou fortemente encadeado, aqui substituidos por longas falas, verdadeiras profissões de fé das personagens, em que o trabalho da interpretação pode ser conduzido de maneira sutilmente analítica." 57

Ele continua:

“Cercando-se dessas honestas preocupações, Gianni Ratto conseguiu realizar um espetáculo límpido, conseqüente, acertadíssimo. Dificilmente poderíamos pegá-lo em flagrante no que se refere à escolha do tom e do gosto da representação. Já não falamos na cenografia, de grande e severa beleza, filiando-se instintivamente no construtivismo de certas encenações de Meierhold (especialmente as que tiveram cenários da Exter), embora suavizado por uma delicadeza latina e católica. „58

\footnotetext{
${ }^{57}$ In "Crítica da Razão Teatral - O Teatro no Brasil Visto por Ruggero Jacobbi”, organizado por Alessandra Vanucci.Editora Perspectiva.São Paulo. 2005. p.38

${ }^{58}$ Id. p. 39
} 
E ainda:

“...Mas o valor do espetáculo reside na clareza com que nos são apresentados os sucessivos aspectos do drama, cuja construção é toda revelada, e até mesmo inteligentemente simplificada, pelo diretor através de uma hábil substituição do humano ao intelectualístico, todas as vezes que o texto o permite". 59

Gianni Ratto exprime sua opinião sobre o texto de Jean Anouilh, registrada no programa de estréia da peça, e inauguração do teatro. Diz ele:

"Anouilh traça um desenho geométrico e sobre o centro de uma tela de aranha lança, debatendo-se, a jovem que ninguém poderá vencer, porque no final é o tema da pureza que triunfou e que sempre triunfará, no limiar de uma transformação retórica, apesar das insídias mais sutis e dos ataques mais diretos. O conflito entre a pureza e um mundo sempre ávido de destruí-la, para depois se comover, está claramente definido nas palavras de Warwick, quando visita Joana no cárcere. "É um estado de graça ser donzela. Nós homens adoramos isso, e, infelizmente, assim que encontramos uma, nos apressamos em fazer dela mulher, e pretendemos que o milagre continue... que loucos que somos.

Não se trata, portanto, de uma interpretação histórica e nem mesmo de um julgamento cujas pretensões sejam concluir definitivamente o problema. Substituindo os nomes de Warwick, de Joana, de Cauchon, do Promotor, do Inquisidor, do Delfim, de Agnes, o resultado será o mesmo, apenas com a diferença que teremos, ao invés de um drama histórico, uma amarga e sorridente análise da nossa sociedade.

\footnotetext{
${ }^{59}$ Ibid.
} 
Apesar de tudo isso, parece ser esta a mais autêntica de todas as Joanas de tempos em tempos apresentadas pelo teatro, pelo menos a mais atual, a mais clara. É fácil nela reconhecer as nossas mais secretas aspirações, a necessidade de lutar pelos mais puros valores dissolvidos pela indiferença geral, sacrificados por uma loucura coletiva que nos impede, constantemente, de reconhecermo-nos e reencontrarmo-nos."

É clara a preocupação do diretor, na escolha do texto, com sua função questionadora perante o público e, talvez, sua analogia com o momento que ele estava vivendo com o grupo no qual estreava como diretor.

A preocupação com o todo, com a junção de todas as peças do quebra-cabeça que é um espetáculo, com a não valorização de determinado ponto em detrimento de outro é muito clara já nesta sua primeira montagem. Finalizando a análise desta sua primeira montagem cabe deixar registrado o depoimento de sua amiga a crítica teatral Bárbara Heliodora sobre o espetáculo e também a atuação do ator Sérgio Britto.

"O Canto da Cotovia foi inesquecível, foi uma coisa fantástica, realmente foi um espetáculo de uma beleza, uma coisa incrível, e muito bem dirigido. E, engraçado, acho que foi um ponto crítico na carreira de Sérgio Britto. Porque o Sérgio, que tinha estreado num Hamlet mediocre, não tinha nada de excepcional, ao contrário tinha um Sérgio Cardoso, que era um esplendor, e o Sérgio Britto não, era muito modesto. Então, o caminho da composição do personagem foi o que realmente abriu o caminho para o Sérgio Britto no teatro. E ele fazia o Delfino (Delfin), no Canto da Cotovia, maravilhosamente bem, e dai é que ele começou a fazer papéis de composição até chegar ao amadurecimento como ator que ele chegou hoje em dia. De maneira que eu acho que ele aprendeu muito com Gianni Ratto e que ele foi um professor para uma porção de gente. Ele formou uma geração. Mas é porque ele tinha essa visão completa do teatro. Completa. Ele via o equilíbrio entre o texto e a encenação, ele não dava preferência 
nem ao texto, nem à encenação. Ele sabia que o teatro é bom quando tudo está junto. O teatro é um quebra-cabeça em que todos os pedacinhos têm que entrar no lugar, e fazer o que deve. Aquele negócio que sempre dizem que não adianta o ator principiante entrar em cena e dizer: "Está servido o jantar" (empostado) porque isso estraga o espetáculo, não ajuda ele, não faz nada. Cada um tem que fazer a sua parte, dentro da medida de sua parte. E isso, e o primeiro ator não tem mais nem menos obrigações que o último dos figurantes. Cada um tem que fazer a sua parte direito. Isso é que o Ratto tinha. Essa preocupação com o todo. Não adianta fazer um papel ótimo e o resto horrível, não! Você tem que equilibrar o espetáculo para ele ficar realmente harmonioso e significativo. ${ }^{, 60}$

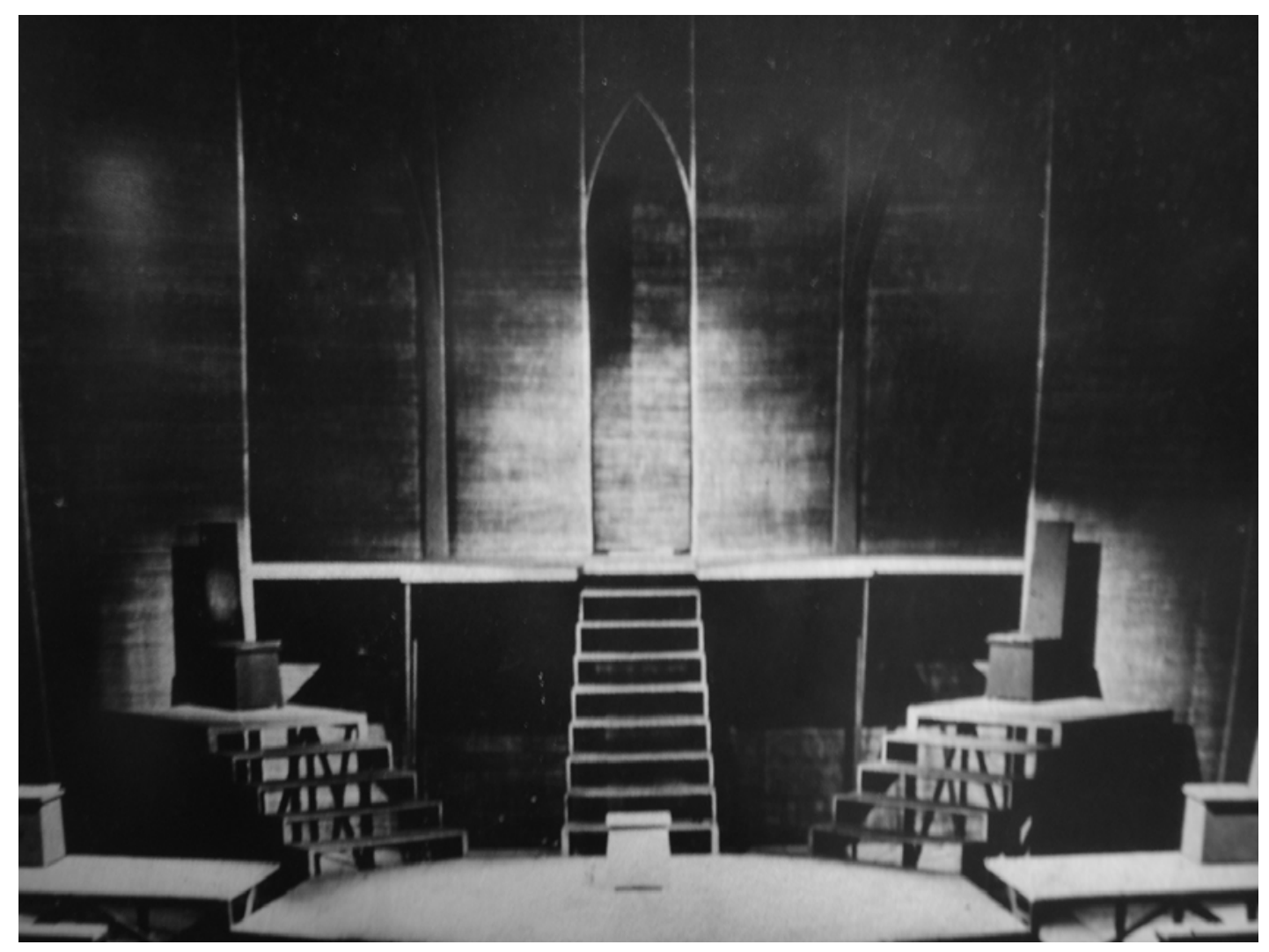

Cenário de Gianni Ratto para o Canto da Cotovia (1954)

\footnotetext{
${ }^{60}$ Entrevista concedida por Bárbara Heliodora ao autor da dissertação, em agosto de 2006.
} 


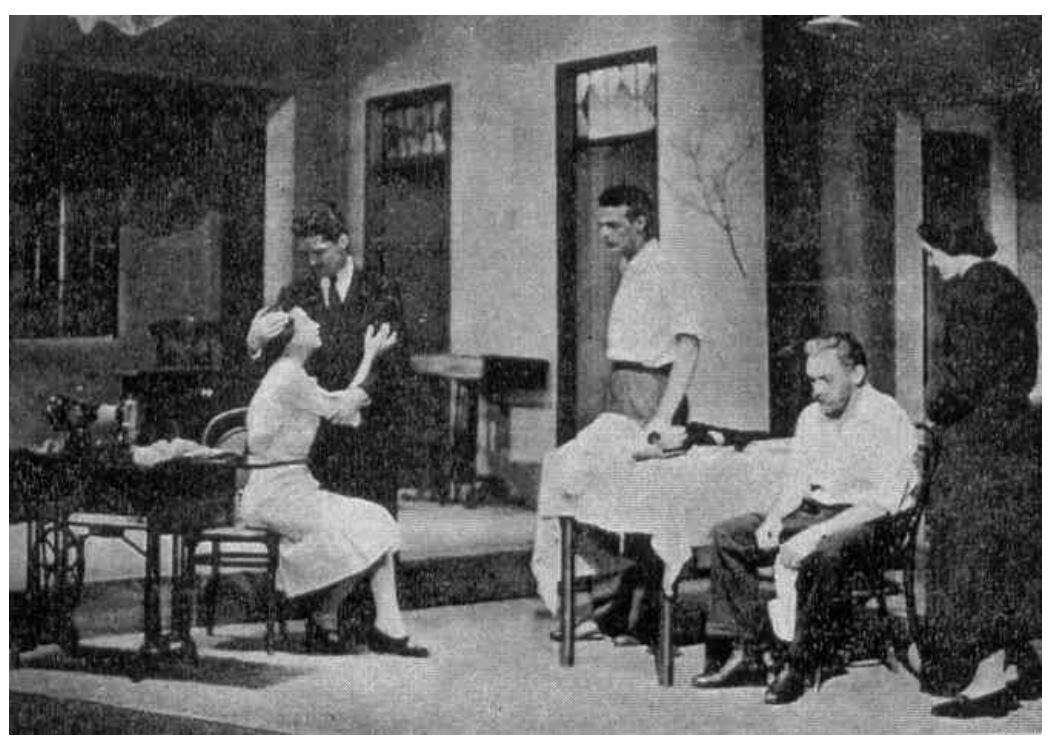

Fernanda Montenegro, Sérgio Britto, Milton Moraes, Elísio de Albuquerque e Moná Delacy

Cena de A Moratória, de Jorge Andrade.

(montagem de 1956 - Direção Gianni Ratto)

\section{O autor}

Aluísio Jorge Andrade Franco nasceu em Barretos, São Paulo, em 1922, e faleceu em 1984, na cidade de São Paulo. Um dos mais expressivos dramaturgos paulistas e brasileiros, retrata com funda verdade e grande poesia cênica diversos panoramas da vida ligada à herança cafeeira; dedicando-se, posteriormente, a temas contemporâneos à sua época e ligados à vida metropolitana.

Jorge Andrade concluiu sua formação como dramaturgo na Escola de Arte Dramática (EAD), em 1954. Seu primeiro texto O Telescópio, foi escrito em 1951 e dirigido por Paulo Francis, no Rio de Janeiro, com o elenco da Companhia Dramática Nacional (CDN), apenas em 1957.

Filho de fazendeiros e tendo vivido a cultura do meio rural, o autor trouxe para a cena profundas observações desse universo, especialmente sua derrocada e adaptação ao meio urbano, fonte dos conflitos que atravessaram a maior parte de suas criações, como A Moratória, encenada em 1955, por Gianni Ratto para o Teatro Popular de Arte, companhia da atriz Maria Della Costa, que lançou a jovem Fernanda Montenegro. Foi 
esse texto que projetou nacionalmente o autor, consagrando-o para a dramaturgia nacional.

Em 1958, é encenado, pelo Teatro Brasileiro de Comédia (TBC), seu texto Pedreira das Almas, que retrata o período do esgotamento da exploração aurífera em Minas Gerais, durante a Revolução de 1842, tendo na sua direção o italiano Alberto D’Aversa. Será o próprio TBC o responsável pela encenação de outros textos do autor como A Escada, em 1961, dirigido por Flávio Rangel; Os Ossos do Barão, em 1963, com direção de Maurice Vaneau e, no ano seguinte, Vereda da Salvação, encenação de Antunes Filho, de 1964.

O recurso da metalinguagem - evidenciando explicitamente os procedimentos da ficção dramática bem como a exploração do tempo - superposição ou concatenação de ações no passado e no presente - contribuem para o refinamento expressivo de sua dramaturgia.

Trabalhando para a revista Realidade, Jorge Andrade é colocado frente a frente com os dramas da metrópole. Desses confrontos, nasce em 1963, Senhora da Boca do Lixo, sobre uma decaída protagonista da sociedade tradicional, que vive de contrabando. Presa, acaba encontrando a liberdade graças às ligações que ainda mantém com altas personalidades.

Rasto Atrás retrata um ajuste de contas com o passado do autor e seus irreconciliáveis conflitos com o pai. A peça ganhou uma encenação de Gianni Ratto, em 1966, para o Teatro Nacional de Comédia (TNC).

Em 1969, surgem duas novas realizações do autor: As Confrarias, em que flagra a vida das estratificadas sociedades eclesiásticas de Vila Rica, tomadas como metáforas da pouca mobilidade social, tendo como pano de fundo o ambiente do Brasil Colônia; e O Sumidouro, na qual põe em cena o dramaturgo Vicente e o bandeirante Fernão Dias.

A ditadura não deixa de inspirar o autor: para a Primeira Feira Paulista de Opinião escreve A Receita, encenada por Augusto Boal, em 1968. Em 1977, lança Milagre na Cela, proibida pela Censura, porque exibe o estupro praticado por um delegado, além da violência dos torturadores durante as sessões de sevícias de uma 
freira. Baseada em fatos reais, o texto somente conseguirá subir à cena em 1981, numa encenação carioca do grupo Barr. Também em 1981, Jorge escreve um dos elos-atos da peça A Corrente, sendo que os outros dois são de Consuelo de Castro e Lauro César Muniz, para um espetáculo com Rosamaria Murtinho e Mauro Mendonça, enfocando três casais entrelaçados por uma trama em comum.

Alguns de seus textos ainda permanecem inéditos, como por exemplo: As Colunas do Templo,1952; Os Crimes Permitidos, 1958; Os Vínculos, 1960; O Mundo Composto, 1972; A Zebra e A Loba, ambas de 1978.

Os sérios conflitos que manteve com o ambiente familiar, especialmente com seu pai, que não aceitava nele a existência de um artista, motivaram Jorge Andrade a refletir, em sua dramaturgia, sobre as questões que envolviam a terra, a família e a sociedade.

Recebeu o prêmio Molière, de teatro, pela publicação de parte de sua obra, no livro Marta, a Árvore e o Relógio, em 1986. É também reconhecido ao longo da carreira através de algumas premiações, como o Prêmio Saci de melhor autor por A Moratória, 1955, e por Os Ossos do Barão, 1963; Prêmio da Associação Paulista de Críticos Teatrais, APCT, de melhor autor por Pedreira das Almas, 1958; A Escada, em 1961; e Vereda da Salvação, 1964. No ano seguinte, ganha, por Rasto Atrás, o primeiro lugar de melhor autor do Serviço Nacional de Teatro, SNT.

Escreveu ainda algumas telenovelas e casos especiais, com destaque para Os Ossos do Barão, inicialmente em 1973 e regravada em 1997, O Grito, 1976; As Gaivotas, 1979; O Fiel e a Pedra, 1981; Os Adolescentes, 1981; A Escada, 1981; Ninho da Serpente, 1982; e Mulher Diaba, em 1983. Seu texto Vereda da Salvação transforma-se em filme, dirigido por Anselmo Duarte, em 1965.

O ponto de partida para torná-lo um autor conhecido foi dado através do crítico de teatro Décio de Almeida Prado que, sabendo do interesse de Gianni Ratto em montar textos nacionais, como forma de valorizar a dramaturgia brasileira, fez com que o apresentasse ao diretor que, entusiasmado com seu texto decidiu encená-lo no Teatro Popular de Arte, obtendo reconhecido sucesso. 


\section{A história}

O elemento estrutural mais importante dessa obra é a sua organização sistematizada em dois planos e três atos. Dessa forma, o autor nos mostra um primeiro plano denominado Plano do Presente, que se passa, aproximadamente no ano de 1932, tendo como espaço a sala de uma modesta casa. O segundo plano, chamado Plano do Passado, situa-se em 1929, no espaço de uma fazenda tradicional. Além de quebrar a linearidade que tornaria o texto e a encenação um tanto quanto monótonos, essa organização permite aos espectadores o acesso simultâneo aos dois instantes fundamentais da história, levando a uma comparação, prevista pelo autor, para comentar e sublinhar os fatos sobre os quais quer chamar a atenção. Assim, os espectadores não podem contar nem ao menos com o benefício da dúvida, uma vez que sabem, antecipadamente, que toda esperança é inútil. O que, de certa forma, os fazem sofrer mais que as personagens.

A ação da peça se desenvolve próxima de seu desfecho, tendo, como já mencionado, dois momentos fundamentais: o passado, que acontece próximo a perda da fazenda seguindo até sua encenação; e o atual (1932), da esperança de retorno com base na moratória e no resultado do processo de nulidade até a decisão final do juiz, com a derrota definitiva, e que põe fim a toda e qualquer esperança.

Assim como a ação, o espaço cênico é dividido em dois. $\mathrm{O}$ espaço da fazenda não se manifesta de modo concreto e genérico, mas por meio de pequenos detalhes que são mencionados pela conversa das personagens, como o balaústre que está estragado, os vidros da bandeira da porta que estão pedindo troca, ou mesmo as formigas que tornaram a aparecer. Importante notar, que esses sinais apontam todos, infalivelmente, para a ameaça de morte (decadência) que paira sobre a fazenda ou, simbólicamente, sobre a classe dominante à época, a qual ela representa, os fazendeiros do café.

As personagens podem ser definidas, rapidamente, da seguinte forma: Helena, mulher bondosa, boa mãe e esposa, humilde, que ama a todos de maneira bem distribuída, procurando compreender e aceitar cada um com suas virtudes e seus defeitos. Joaquim, homem sistemático do interior, de aparência forte, mas bastante sensível interiormente. Cuida de todos os negócios, não permitindo que as mulheres se 
metam em atividades que julga serem apenas dos homens. Não aceita qualquer tipo de ajuda e, dessa forma, sofre muito quando a filha precisa costurar para ajudar no sustento da família. Tradicionalista ao extremo, não aceita qualquer tipo de mudança na sua vida, e na sociedade. Dono de uma fazenda que herdou, consegue melhorá-la, mas não consegue administrá-la durante a crise econômica. Marcelo, filho de fazendeiro, nada quer da vida, evitando qualquer esforço físico ou intelectual. Quer desfrutar dos benefícios que a posição do pai lhe proporciona e, quando tudo desanda, refugia-se na bebida. Lucília, moça forte, de temperamento enérgico e paciente, única no conjunto familiar preparada para a nova vida de sofrimento e luta pelo pão de cada dia. Orgulhosa, no entanto, não gosta de aceitar ajuda dos parentes. Realista, aceita com resignação a nova situação familiar. Olímpio é o noivo de Lucília. Advogado, tenta auxiliar o futuro sogro na nulidade da ação que o fará perder a fazenda. Elvira é a irmã de Joaquim, também casada com um fazendeiro, o qual arremata a fazenda do cunhado. Algumas vezes traz alimentos à família do irmão e se beneficia, sem pagamento, das costuras que a sobrinha faz para ela.

De forma resumida podemos dizer que A Moratória é uma história que trata de assuntos sociais e psicológicos tipicamente paulistas - ou não -, quais sejam a decadência da antiga classe dirigente, o conflito entre gerações, o trágico apego à terra, e a crise moral e religiosa da burguesia latifundiária. Assuntos esses que, não obstante o regionalismo apontado, se insere perfeitamente em qualquer cidade do mundo.

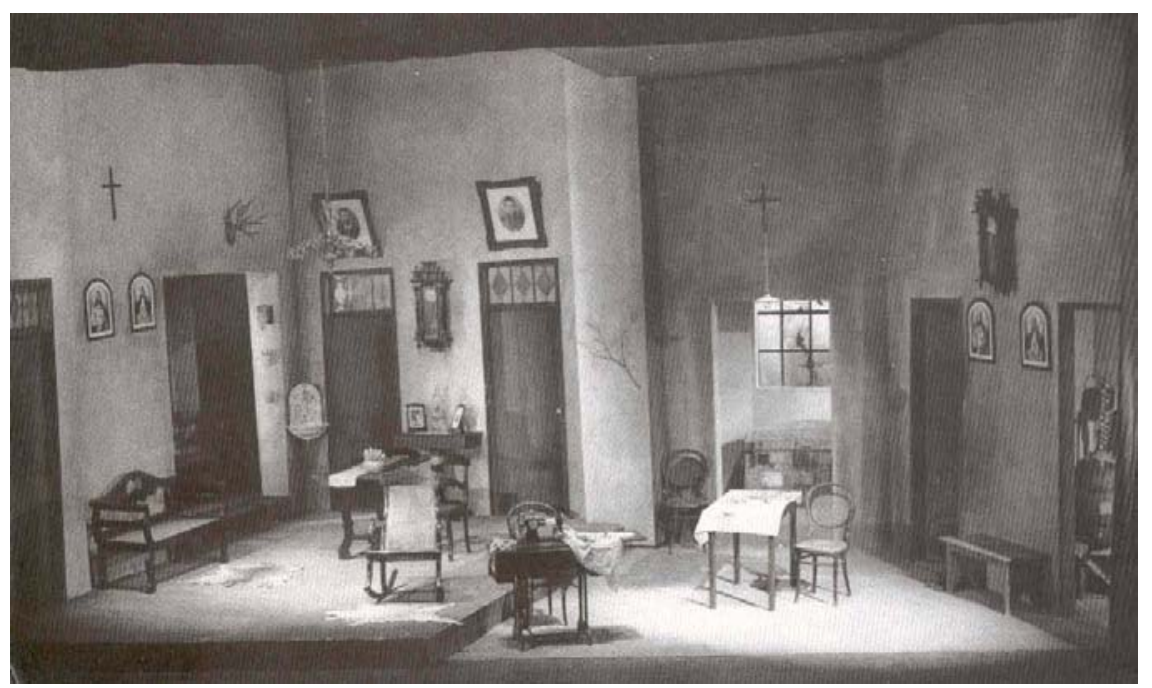

Cenário de Gianni Ratto para o espetáculo de 1955, onde pode-se observar os dois planos mencionados no texto. 


\section{O texto e a montagem}

A montagem do texto A Moratória, de Jorge Andrade, como já mencionamos se deu por indicação do crítico teatral Décio de Almeida Prado. Após o êxito da comédia Com A Pulga Atrás da Orelha, de Georges Feydeau, que sucedeu a premiada O Canto da Cotovia, de Jean Anouilh, Gianni estava a procura de um texto, de dramaturgo brasileiro, para a nova montagem da companhia de Maria Della Costa. Sua intenção era a de valorizar o autor nacional, mostrar ao público a verdadeira dramaturgia brasileira. Décio, então, lhe apresentou Jorge Andrade, recém saído da Escola de Arte Dramática. O diretor ficou entusiasmado com o texto, sugerindo sua montagem à Maria e seu marido, Sandro Polloni.

De acordo com a proposta da peça para o novo espetáculo da companhia surge um problema. Ao ler o texto Gianni não vê em Helena, a jovem protagonista, um papel para Maria Della Costa, desejando que a atriz Fernanda Montenegro, membro da companhia ficasse com a personagem. Este seria o primeiro papel de protagonista da atriz, o qual lhe abriria portas para que demonstrasse seu talento dramático. Muito delicadamente Gianni Ratto teve uma conversa com Maria Della Costa que, generosamente, como sempre mencionou em suas conversas, cedeu o papel para que Fernanda Montenegro pudesse protagonizar a peça. A "fama" de mulherengo do diretor também teve influência sobre a decisão de a atriz protagonizar a peça, é o que revela Maria Della Costa:

"Eu nunca toquei nesse assunto, mas eu acho que o Gianni Ratto....Foi como eu te disse, ele era muito apaixonado, e tal... E ele teve uma paixão por mim também, mas eu era muito bem casada com o Sandro. E a Fernanda estava na minha companhia. Então eu achei por bem, e isso ninguém soube. Eu disse, olha Sandro eu quero fazer a operação da garganta, e vou aproveitar e você faz o Jorge de Andrade (A Moratória) com a Fernanda Montenegro, com o Gianni Ratto. Porque eu não podia, eu queria ver se o Gianni esfriava. 
Porque era uma coisa que já estava me incomodando, aquela coisa dele, aquela atração dele por mim. "61

Todavia, a atriz como ela mesma conta, poderia ter insistido e protagonizado a peça, mas seu respeito pelo diretor era maior, como também sua generosidade para com os outros colegas da companhia:

"Eu vou te dizer uma coisa.... Se eu fosse uma egoísta, se eu quisesse realmente ser a estrela, estrelíssima, eu enfrentava o Gianni e fazia o personagem. Era a minha Companhia! Eu dizia, Gianni por favor, eu sou casada, você pára. Eu ia ter uma conversa com ele, e ia continuar. Entendeste como é? Mas como eu era uma pessoa muito sensivel, e ele um grande diretor, e eu não queria perdê-lo como diretor... Porque nós estávamos com um teatro, pagando um teatro, com um elenco grande, fazendo sucesso, ele um "puta" de um diretor entende? Como ser humano, como tudo. Então, deixa eu sair fora. E a Fernanda, era uma grande atriz, como ficou comprovado!,"62

A Moratória teve como mérito ser o ponto de partida para a renovação do repertório que era representado nas salas de teatro paulistas. O espetáculo estreou no dia 6 de maio de 1955, tendo no elenco Elísio de Albuquerque, Moná Delacy, Fernanda Montenegro, Milton Morais, Sérgio Britto e Wanda Kosmos. Assim como a direção, a cenografia era assinada por Gianni Ratto, sendo os figurinos de sua então esposa Luciana Petrucelli. A assistência de direção coube a Fernando Torres.

Fernanda Montenegro comenta também a sua entrada na montagem de A Moratória e sua participação na Companhia de Maria Della Costa:

“Ele (Gianni) tinha uma ética muito grande também. Ele não rachava companhias, compreende? Eu era recém chegada à companhia da Maria, substitui lá, fiz alguma coisa na Cotovia, depois fiz uma parte na Pulga Atrás da Orelha, e um dia me comunicaram

\footnotetext{
${ }^{61}$ Entrevista concedida por Maria Della Costa ao autor da dissertação em janeiro de 2007.

${ }^{62} \mathrm{Id}$.
} 
que eu ia fazer A Moratória, Maria estava muito doente. E também eu agradeço muito a Maria, porque se fosse outra atriz diria: Ah não, de maneira nenhuma, eu sou a dona da companhia........) (...) Quer dizer, houve um acordo ali. E foi um trabalho revelador para mim. Eu vi que eu tinha um diretor... "63

A crítica Bárbara Heliodora também fala da escolha da peça por Gianni Ratto. Ela comenta:

Pois é, bom, mas isso foi muito engraçado. Porque nos Comediantes, foi um polonês, o Ziembinski que disse assim "Ó, vocês têm uma peça brasileira ótima pra montar que é o Vestido de Noiva”. Porque Os Comediantes, o repertório deles, era de peças inglesas, francesas etc. E foi o Ziembinski que disse:, "Mas tem uma brasileira ótima aqui”. E foi no teatro da Maria Della Costa que ele (Gianni) estreou com o Canto da Cotovia, e tudo isso, ele é que pegou A Moratória do Jorge Andrade e disse: Mas aqui tem uma peça brasileira que vale a pena montar. E ele fez uma coisa ainda mais fenomenal que foi persuadir a Maria Della Costa, que era a dona da companhia, a dar o papel a Fernanda, que estava despontando, ali é que ela foi revelada. Mas ele entendia que o papel não era para a Maria, e que a Fernanda poderia fazer muito bem e com isso a peça iria funcionar muito bem. E realmente a cenografia dele foi maravilhosa, separando as casas. Que era o mesmo cenário com mais riqueza e mais pobreza. Era a mesma família que morava, mas depois que faliram, então, as coisas eram pobres em vez de serem ricas. Mas foi uma contribuição. Por isso digo que o Ratto foi interessante porque se interessou pelas coisas brasileiras, ele se interessava por ter eventualmente autores brasileiros, ele se integrou muito no Brasil, mas sem perder as exigências clássicas do europeu. ${ }^{64}$

\footnotetext{
${ }^{63}$ Entrevista concedida por Fernanda Montenegro ao autor da dissertação, em agosto de 2006.

${ }^{64}$ Entrevista concedida por Bárbara Heliodora ao autor da dissertação, em agosto de 2006.
} 
A forma de trabalho do diretor, à época, também é lembrada pela atriz:

“...ele não fazia muitos exercícios corporais. O problema era vencer, mais do que vencer, era despertar a inteligência cênica da gente pelo imaginário. „65

Ela prossegue:

"Eu me lembro que nós fizemos na Maria Della Costa um espetáculo do Sérgio Toffano chamado A Ilha dos Papagaios, em que a gente trabalhou muito fisicamente. Tinha canto, já tinha alguma dancinha, compreende? Eu fazia a Duruk, que era uma negrinha, de malha, que tinha que pular numa perna, na outra, tinha que sair correndo... Então todos nós nos exercitamos muito fisicamente pra esse espetáculo, mas o grande trabalho dele era na massa poética do texto, era no entendimento psicológico, a inter-relação das personagens, o jogo das $\boldsymbol{n}$ possibilidades que uma cena possa ser jogada, entende?(...) (...)Hoje a grande deficiência que acho, é que os jovens atores não sabem falar. Mas não sabem falar na propriedade cênica, na propriedade daquela dramaturgia. Há também uma espécie de relaxamento com relação à dramaturgia. A propósito de uma peça faz-se um espetáculo, a propósito de um poema faz-se um espetáculo, a propósito de um livro, faz-se um espetáculo. Eu acho isso maravilhoso, eu não censuro isso não, eu acho que toda maneira de amar vale a pena, não é? Então parece que isso dá uma certa permissividade ao artista de ir por onde for, não é? Se não sabe resolver bem, corta-se, facilita-se. Ou então, se endurece, porque não consegue e se enrijece, se estrangula, desloca as tônicas das frases. Não sei se ensinam isso nas escolas. Essa grande escola, eu tive com Gianni Ratto, que sempre evitou dar a sonoridade, vamos dizer a intenção, ele representar pra gente copiar...,

\footnotetext{
${ }^{65}$ Entrevista concedida por Fernanda Montenegro ao autor da dissertação, em agosto de 2006.

${ }^{66} \mathrm{Id}$.
} 
Os críticos são unânimes em louvar a importância do texto de Jorge Andrade. A crítica de Ruggero Jaccobi, publicada em 9 de maio de 1955, na Folha da Noite, se inicia de forma efusiva:

"Que os três penachos de fumaça branca surjam e ondulem ao vento sobre a cúpula da basílica das letras teatrais brasileiras: habemus pontífice. Com a apresentação deste drama de Jorge Andrade, a renovação de nossa arte dramática que, apesar dos esforços de tantos abnegados, permanecera até agora, essencialmente, renovação da mise-en-scène e da arte de representar, chega ao único resultado capaz de garantir a sua permanência e de definir o seu sentido: a criação de um autor absolutamente nacional e, ao mesmo tempo, perfeitamente enquadrado dentro da situação histórica e estética da poesia dramática universa deste pós-guerra ${ }^{, 67}$.

Gilda de Mello e Sousa finaliza um artigo sobre o texto de Jorge Andrade com as seguintes palavras:

"A Moratória nos revela um autor prisioneiro, como as suas personagens, do espaço e do tempo perdido da fazenda. Mas consciente de que este mundo extinto só pode agora ser refeito pela imaginação. Jorge Andrade lhe dá permanência através da obra de arte. - A Moratória é a primeira obra de arte verdadeira do moderno teatro brasileiro." 68

Gianni Ratto, desde o início acreditava no texto de Jorge Andrade. Como já foi dito, o diretor buscava o novo, sua preocupação com a qualidade e a dramaturgia, principalmente a brasileira, uma vez que se encontrava em nosso país, era patente. Além do mais tinha por experiência o próprio Piccolo, de onde viera e era um de seus fundadores, pois a importância do repertório do grupo de Strehler só acontecia porque ao lado de Sófocles, Pirandello, Goldoni, arriscava-se em novos textos nacionais.

\footnotetext{
${ }^{67}$ In Folha da Noite. São Paulo, 09 de maio de 1955.

${ }^{68}$ In Teatro Brasileiro n 3 - Janeiro de 1956 - p. 09
} 
Jorge Andrade já havia escrito dois textos anteriores a este, O Telescópio e As Colunas do Templo, mas tanto estes como A Moratória, apesar de premiados nos habituais concursos de peças de teatro não haviam ainda sido encenados. "Os italianos do TBC não acreditavam em Andrade como autor, ou, pelo menos, o consideravam perigoso na bilheteria”, conta-nos Sérgio Britto em sua biografia Fábrica de Ilusão. ${ }^{69}$

Com relação à montagem, apreende-se que Gianni Ratto mantinha ainda sua preocupação com o estudo minucioso da personagem, a imersão total no texto com a finalidade de revelar o que o autor queria transmitir ao público. É o que nos revela Sérgio Britto, ator desta montagem:

"A esse texto tão simples e tão brasileiro, Ratto serviu com uma cenografia e uma ambientação de alta qualidade poética e uma direção de uma humildade rara. Os atores foram trabalhados a exaustão, cada pausa, cada tempo, cada movimento. Sem diminuir a qualidade do elenco, A Moratória foi um sucesso, antes de tudo, do diretor Ratto.

Ratto resolveu esse ritmo interno do seu espetáculo progressivamente: primeiro o insinuou na leitura de mesa, frisou uma ou outra pausa mais importante, sugeriu que existiam outras que os atores mesmos deveriam descobrir e, para finalizar, diante de uma certa frustração das pausas que não surgiram como ele as queria, regeu esses tempos, levando o elenco a um ritmo que muitos poderiam achar lento e perigoso de ser suportado pelo público, mas que foi, tenho a certeza, a explicação da emoção que o espetáculo transmitia". 70

O cuidado do diretor com a concepção das personagens é lembrado quando o ator fala das interpretações de seus colegas de elenco:

"Elísio de Albuquerque e Monah Delacy faziam o casal central da peça e os dois realizaram uma composição repassada de excepcional emoção. Os seus tempos

\footnotetext{
${ }^{69}$ BRITTO, Sérgio. "Fábrica de Ilusão - 50 Anos de Teatro”. pág. 58. Salamandra - Funarte. 1996.

${ }^{70}$ Id. p. 59.
} 
mortos, os gestos cansados, os olhos embaciados de lágrimas que resistem e não caem, seus movimentos de autômatos desesperados e impotentes, eram um grande sucesso da direção e uma grande afirmação para Elísio e Monah. "71

O crítico de teatro Miroel Silveira, no entanto, mesmo discordante quanto a importância do texto de Jorge Andrade, encontrando mesmo muitos defeitos na sua composição, quer seja na concepção das personagens, quer seja no aspecto psicológico e social da ação, não deixa de elogiar a encenação de Gianni Ratto. Diz ele:

"Em A Moratória tem Gianni Ratto seu melhor trabalho de direção até agora. Registro com prazer o progresso que conseguiu no rendimento das interpretações, quase todas muito boas. Embora como encenação o espetáculo seja limitado pela modéstia do tema, quanto ao ritmo e à verdade psicológica A Moratória marca para Gianni Ratto pontos muito acima de O Canto da Cotovia e Com a Pulga Atrás da Orelha. Tratando-se de uma peça nacional, esse fato é duplamente auspicioso, Fernanda Montenegro, Mona Delacy, Elísio de Albuquerque e Milton Morais estão magníficos, e Vanda Kosmo o segue de perto. Apenas Sérgio Britto - esplêndido ator de caráter não consegue compor com suficiente verossimilhança a simplicidade de seu personagem.",72

A opinião de Gianni Ratto, quanto a importância do texto de Jorge Andrade é bem diversa daquela levantada por Miroel.

Verifica-se, portanto, que antes de qualquer coisa, para Gianni Ratto, o bom texto é o que importa, a palavra do autor é que deve ser comunicada. É através dele que se poderá criar um espetáculo digno, correto, se for bem trabalhado, estudado. A seguir, suas considerações sobre esta obra de Jorge Andrade:

"A perspectiva dos dias que se desenrolam uns iguais aos outros; o desejo amargo e inútil de compreender e ser compreendido; a

\footnotetext{
${ }^{71}$ Id.

${ }^{72}$ SILVEIRA, Miroel - “A Outra Crítica”. São Paulo. Ed. Símbolo. 1976. p157.
} 
passagem cotidiana das horas que se repetem no meio de uma vida que caminha por sua conta; os gestos que não podem ser repetidos e que gostaríamos de conservar; a legitimidade dos direitos de cda geração e o conflito que a posição de uma e o desenvolvimento de outra determinam; a resignação e a rebelião; o amor e o desejo de amor que nos liga e nos divide; o bom senso feito de teimosia e os impulsos que se transformam em revolta autêntica - todas essas coisas, e todas as outras que compõem a peça, pertencem também à nossa história e é fácil reconhecer, nas personagens, nossos pais e nossos amigos. A comoção que deles deriva é, portanto, autêntica, e não poderíamos deixar de participar de suas vidas, que são, enfim, a nossa própria vida - a nossa modesta e amarga história de cada dia e de cada hora. ",73

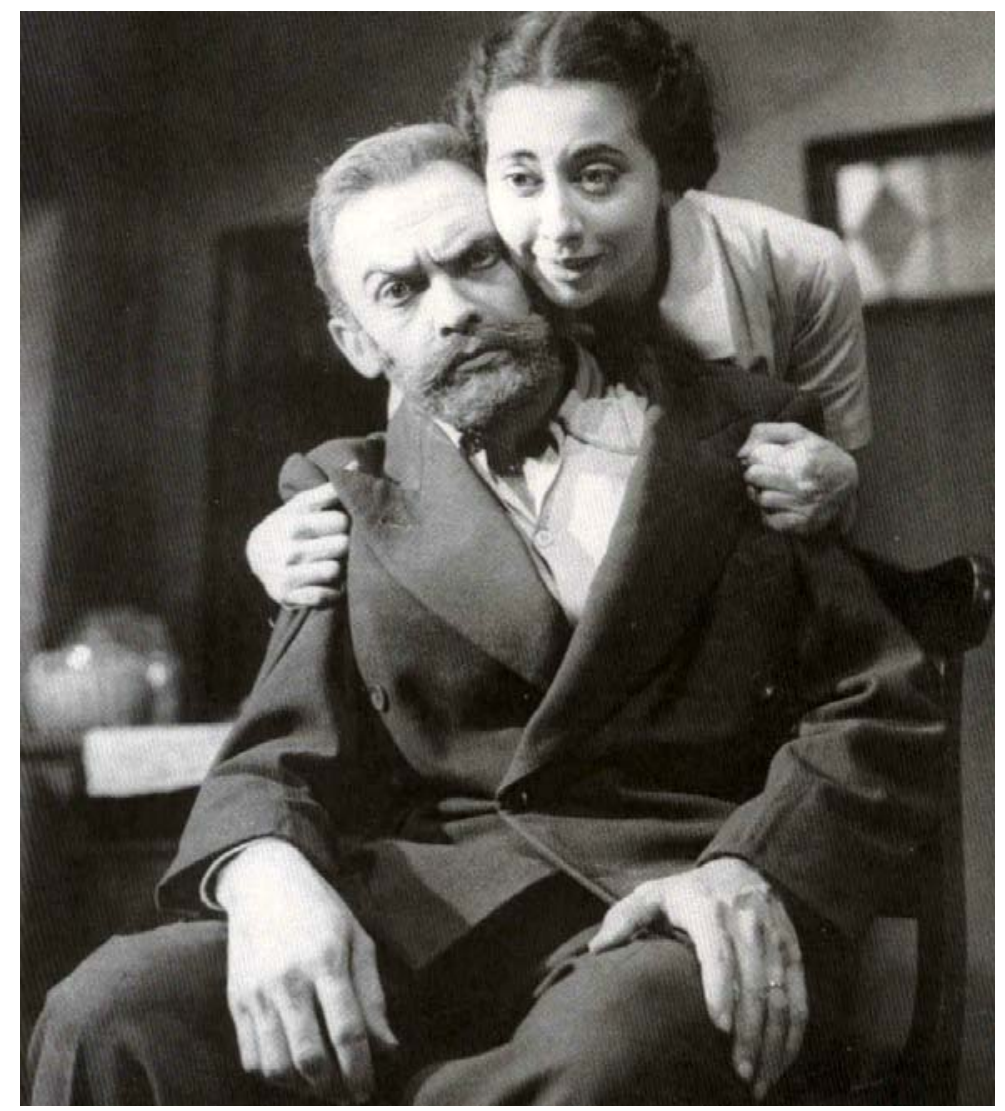

Elísio de Albuquerque e Fernanda Montenegro

A Moratória, 1955 - Direção Gianni Ratto

\footnotetext{
${ }^{73}$ Jorge Andrade - A Moratória . Livraria Agir Editora. Rio de Janeiro. 1989. Orelha do livro.
} 


\section{O Mambembe: O Amor pela Profissão}

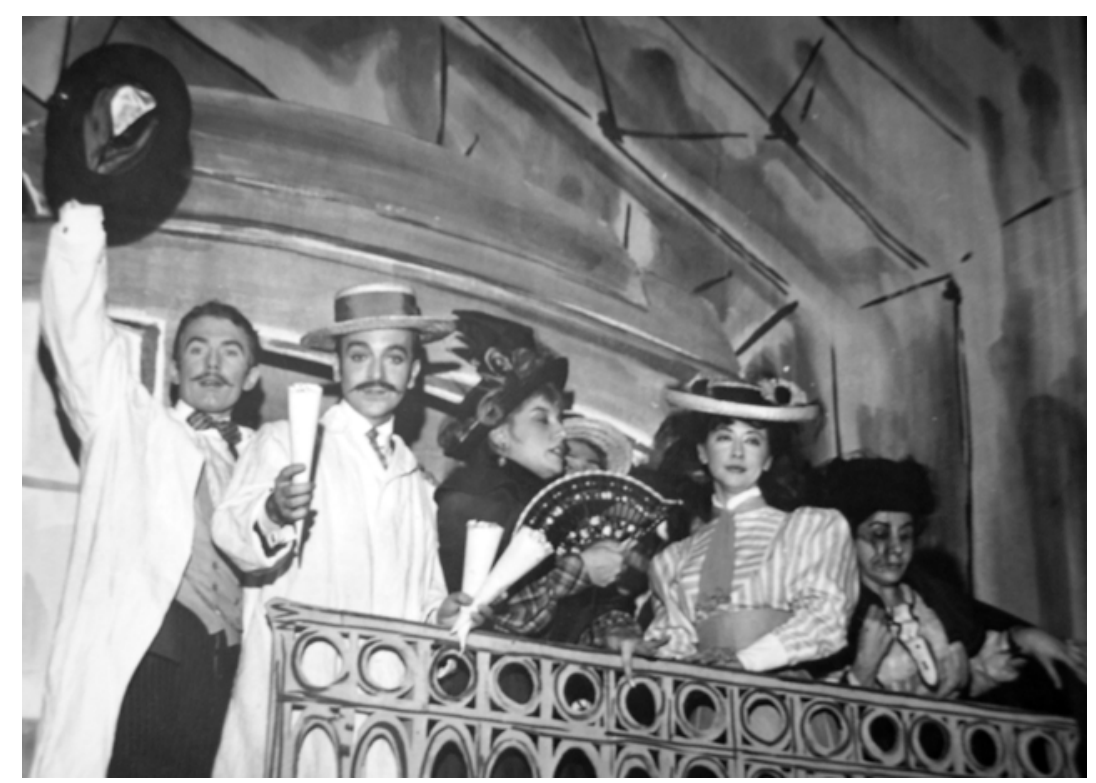

Waldir Maia, Napoleão Moniz Freire, Iolanda Cardoso, Fernanda Montenegro e Grace Moema O Mambembe - 1959 - Direção Gianni Ratto

\section{O autor}

Arthur Nabantino Gonçalves de Azevedo, mais conhecido como Arthur Azevedo, jornalista, poeta, contista e teatrólogo, nasceu em São Luís, no Maranhão, em 7 de julho de 1855, e faleceu no Rio de Janeiro, RJ, em 22 de outubro de 1908. Ao lado do irmão, Auísio de Azevedo, foi um dos fundadores da Academia Brasileira de Letras, onde criou a Cadeira de número 29, cujo patrono é Martins Pena.

Filho de David Gonçalves de Azevedo, vice-cônsul de Portugal em São Luís, e Emília Amália Pinto de Magalhães, mulher corajosa que, separada de um comerciante, com quem casara a contragosto, já vivia maritalmente com o funcionário consular português à época do nascimento dos filhos: três meninos e duas meninas. Os dois vieram a se casar, posteriormente, após a morte, por febre amarela, de seu primeiro marido na Corte.

Já aos oito anos de idade Arthur Azevedo demonstrava pendor para o teatro, brincando com adaptações de textos de autores como Joaquim Manuel de Macedo, passando, pouco depois, a escrever, ele próprio, as peças que representava. 
Muito cedo começou a trabalhar no comércio, atuando em seguida na administração provincial, de onde foi demitido por publicar sátiras contra autoridades do governo. Nessa mesma época, lançava suas primeiras comédias nos teatros de São Luís. Aos quinze anos escreveu a peça Amor por Anexins, que obteve grande êxito, com mais de mil representações no século de seu nascimento. Ao incompatibilizar-se com a administração provincial, concorreu a um concurso aberto, em São Luís, para o preenchimento de vagas de amanuense ${ }^{74}$ da Fazenda. Obtida a classificação, transferiuse para o Rio de Janeiro, no ano de 1873, onde obteve emprego no Ministério da Agricultura.

No início de sua vida na cidade, dedicou-se também ao magistério, ensinando Português no Colégio Pinheiro. Mas foi no jornalismo que ele pôde desenvolver atividades que o projetaram como um dos maiores contistas e teatrólogos brasileiros. Fundou publicações literárias, como A Gazetinha, Vida Moderna e O Álbum. Colaborou em A Estação, ao lado de Machado de Assis, e no jornal Novidades, onde tinha como companheiros Olavo Bilac e Coelho Neto, entre outros. Foi um dos grandes defensores da abolição da escravatura, em seus ardorosos artigos de jornal, em cenas de revistas dramáticas e em peças dramáticas, como O Liberato e A família Salazar, esta última escrita em colaboração com Urbano Duarte e proibida pela censura imperial, mas publicada mais tarde em volume, com o título de O Escravocrata. Escreveu mais de quatro mil artigos sobre eventos artísticos, principalmente sobre teatro, nas seções que manteve, sucessivamente, em O País ("A Palestra"), no Diário de Notícias ("De Palanque"), em A Notícia (o folhetim "O Teatro"). Arthur era pródigo na escolha de pseudônimos: Elói o herói, Gavroche, Petrônio, Cosimo, Juvenal, Dorante, Frivolino, Batista o trocista, entre outros. A partir de 1879, dirigiu, com Lopes Cardoso, a Revista do Teatro. Por cerca de três décadas sustentou a campanha vitoriosa para a construção do Theatro Municipal, a cuja inauguração não pôde assistir.

Embora escrevendo contos desde 1871, só em 1889 animou-se a reunir alguns deles no volume Contos Possíveis, dedicado a Machado de Assis, que então era seu companheiro na secretaria da Viação e um de seus mais severos críticos. Em 1894, publicou o segundo livro de histórias curtas, Contos Fora de Moda, e mais dois

\footnotetext{
${ }^{74}$ Amanuense - Nomenclatura da época para escriturário de repartição pública.
} 
volumes, Contos Cariocas e Vida Alheia, constituídos de histórias deixadas por Arthur de Azevedo nos vários jornais em que colaborara.

Arthur Azevedo foi um descobridor de assuntos do cotidiano da vida carioca e observador dos hábitos da capital, tanto no conto como no teatro. Os namoros, as infidelidades conjugais, as relações de família ou de amizade, as cerimônias festivas ou fúnebres, tudo o que se passava nas ruas ou nas casas lhe forneceu assunto para as histórias. No teatro, foi o continuador de Martins Pena e de França Junior. Suas comédias fixaram aspectos da vida e da sociedade carioca. Nelas pode se encontrar sempre um documentário sobre a evolução da então capital brasileira. Teve em vida cerca de uma centena de peças de vários gêneros e extensão (além de mais de trinta traduções e adaptações livres de peças francesas) encenadas em palcos nacionais e portugueses. Ainda hoje continua presente como a mais permanente e expressiva vocação teatral brasileira de todos os tempos, através de peças como A Jóia, O Tribofe, A Capital Federal, A Almanjarra, O Mambembe, e outras.

Dedicou-se também a poesia, sendo um dos representantes do Parnasianismo, apenas por questão cronológica, uma vez que pertencia à geração de Alberto de Oliveira, Raimundo Correia e Olavo Bilac, os quais sofriam a influência de poetas franceses como Leconte de Lisle, Banville, Coppée, e Heredia. Porém, pelo seu temperamento alegre e expansivo, não poderia ser considerado membro desta escola poética. É um poeta lírico, sentimental, estando seus sonetos perfeitamente dentro da tradição amorosa dos sonetos brasileiros.

\section{A história}

O Mambembe é uma burleta ${ }^{75}$ em três atos, divididos em 12 quadros, ornada de música original de Assis Pacheco.

Trata-se de um enredo simples, em que Arthur Azevedo coloca todo seu amor pelo teatro criticando o desamparo em que a arte cênica, e seus artistas, são deixados pelas autoridades. Uma sátira aos costumes interioranos e até mesmo ao próprio teatro.

\footnotetext{
${ }^{75}$ Burleta - comédia satírica de costumes acompanhada de números musicais.
} 
O ator Frazão organiza um Mambembe, mas luta com dificuldade, não dispondo de uma primeira-dama para a excursão. Lembra-se de atrair para a sua companhia uma amadora de prestígio nos palcos das sociedades particulares do Rio de Janeiro, e efetivamente dirige-se a Laudelina, afilhada de Dona Rita e filha da senhora Gayoso com um mineiro que passara pela corte nos anos de 1879, no tempo em que a cantora Cesano tinha voz e era moça.

Laudelina deixa-se fascinar pela proposta do ator Frazão; Dona Rita tenta desviá-la de seu intento, mas só consegue persuadi-la a servir-lhe de companhia durante a excursão artística. Essa jovem tem um apaixonado, o também amador Eduardo, que com ela representava a "Morgadinha de Val Flor" em Catumbi. O rapaz fica desorientado quando sabe da próxima partida de Laudelina e, para acompanhá-la, obtém de seus patrões uma licença de três meses e engaja-se, sem vencimentos, no mambembe do Frazão. Disposto inclusive a pagá-lo para fazer parte da trupe.

Os incidentes que precedem a formação do grupo são interessantes e passam-se nos fundos de uma venda muito conhecida na Capital Federal, onde reúnem-se os artistas sob a proteção platônica do proprietário do negócio, um português, homem dado à literatura teatral.

O segundo ato se passa na cidade de Tocos, onde chega o Mambembe depois de um mês de peregrinação. O dono do hotel, antigo cômico, não os quer receber fiado, pois ali estivera um outro Mambembe de caloteiros. Dessa forma, as dificuldades tornam-se quase insuperáveis: os artistas estão acampados no meio de um largo, sem casa, sem crédito e com fome, além dos credores que perseguem o empresário, uma vez que até o momento não tiveram sucesso com a empreitada em que se meteram.

Felizmente é dia do aniversário natalício do tenente-coronel Pantaleão, presidente da Câmara Municipal, grão-mestre da Maçonaria, comandante superior da Guarda Nacional, e dramaturgo, autor de Passagem do Mar Amarelo, drama em 12 atos e 21 quadros.

Arranja-se uma manifestação, com música e foguetes, e o homem, enternecido pelos encantos de Laudelina, abre as portas de sua casa ao Mambembe, oferecendo-lhe 
seu drama para ser ali montado. Tenta ele, ao mesmo tempo, seduzir a jovem. Após o fiasco da peça, percebendo o interesse do coronel por sua amada, Eduardo esmurra Pantaleão e é preso em flagrante pelo subdelegado. Porém, após a intervenção do empresário da companhia acaba por ser solto.

A situação do empresário começa a se agravar com a perseguição mais amiúde de seus credores, dando lugar a interessantes cenas descritas com muita graça.

Salva-se a situação inesperadamente pelo convite que o capitão Irineu dirige ao chefe do Mambembe, para que realize três representações em Pito Aceso, cidade próxima de Tocos, por ocasião da Festa do Divino Espírito Santo, e isso com bastante dinheiro, adiantado por ele.

O terceiro ato se passa já em Pito Aceso, onde acontece a procissão do Divino com o coronel fazendo o papel de Imperador da cerimônia e sua esposa (uma madame francesa, antiga dançarina do cabaré Alcazar), o acompanhando sob o pálio branco da comemoração. Chega à cidade Pantaleão que quer a qualquer custo amar Laudelina e fazer representar seu drama, oferecendo-lhe dois contos numa carta.

Frazão, ao saber da tramóia de Pantaleão, disfarça-se em Laudelina e, numa cena impagável, apanha o dinheiro oferecido pelo coronel à suposta jovem.

Enquanto isso, o grupo realiza a representação teatral durante a Festa do Divino, vista por todo o povo do local (e pelos atores/espectadores também). Ela acontece num palco montado sobre barricas, tendo como resultado o seu desabamento durante a representação.

Seguem-se muitos incidentes cômicos, até que chega o momento da partida dos artistas para o Rio de Janeiro. O bom Chico Inácio dá seu cartão a Dona Rita e esta descobre que ele é o Batata, pai de Laudelina. O Sr. Eduardo casa-se com ela, madame aceita a filha, o coronel fica contentíssimo e quando a jovem atriz mostra escrúpulos em abandonar a arte, Frazão, que é digno, acaba com eles e parte para seu vício: arranjar outro mambembe. 
Uma peça de teatro sobre o teatro, metalinguagem para fazer pensar. A organização da companhia, os tipos que a compõem, o estranhamento do público, as crises financeiras, os problemas com as autoridades locais, com a burocracia, com o repertório, com as condições técnicas dos locais de representação, tudo é examinado e, como resultado final, há uma celebração do trabalho dos artistas e do próprio teatro. Sua estrutura segue as convenções do teatro antigo, com galãs, damas, ingênuas e cômicos. Assim é essa história de Arthur Azevedo.

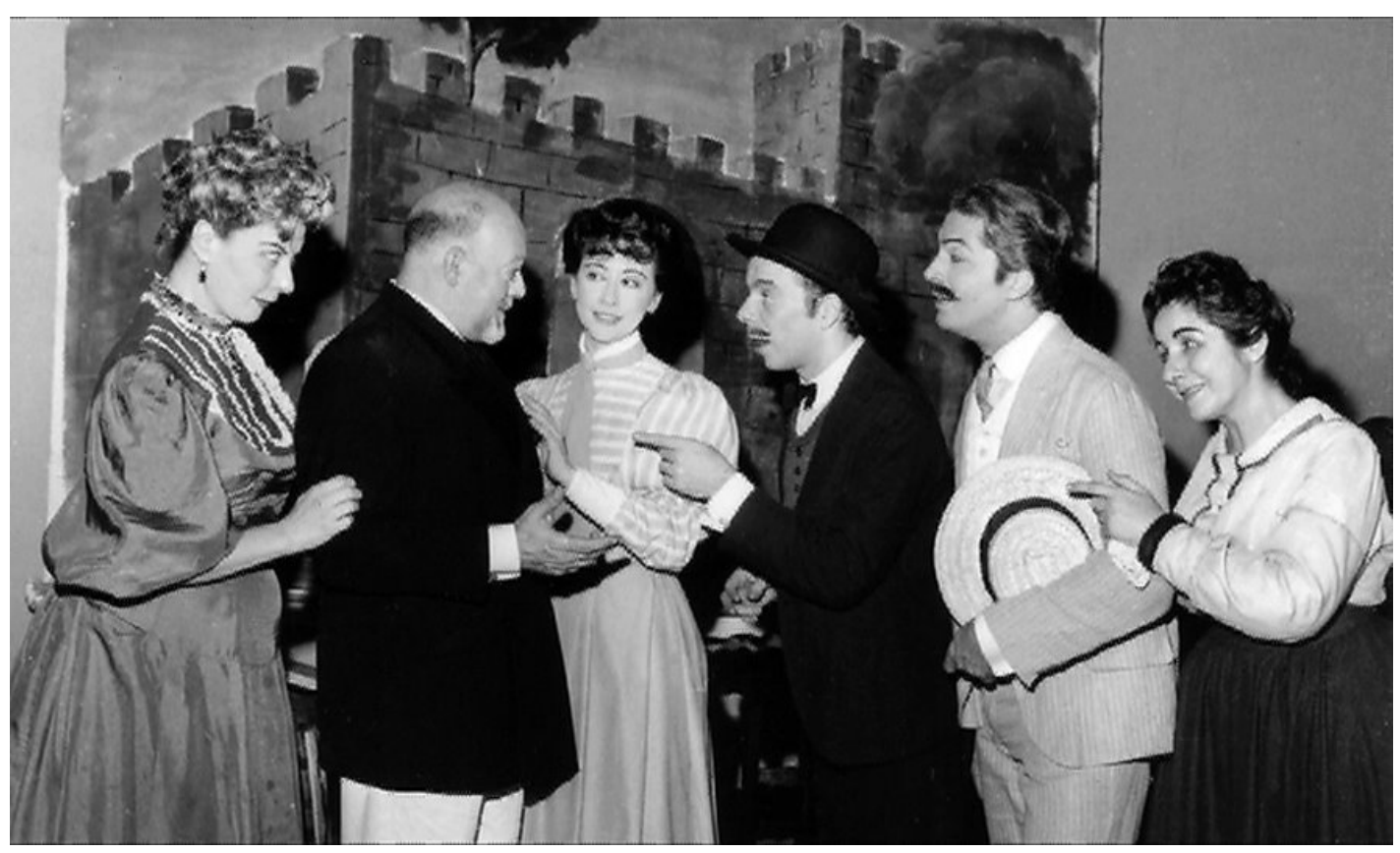

Iara Cortez, Labanca, Fernanda Montenegro, Ítalo Rossi, Sergio Britto e Grace Moema O Mambembe - 1959 - Direção Gianni Ratto

\section{O texto e a montagem}

Apesar de Arthur Azevedo ser um dos maiores dramaturgos brasileiros, tendo escrito aproximadamente 200 peças de teatro, ele não era valorizado junto a classe teatral, e ao público brasileiro, durante o final dos anos 50. Na verdade, como já foi abordado, as montagens que aconteciam nas cidades de São Paulo e Rio de Janeiro, pólos do desenvolvimento teatral, eram de textos de autores estrangeiros. Isso começou a se modificar, como já foi dito, com o lançamento de Jorge Andrade como autor por Gianni Ratto, gerando conseqüências positivas para a dramaturgia nacional. Aliado ao 
momento político por que passava o país, alguns grupos se aventuraram na montagem de textos de autores nacionais, como foi o caso do Teatro de Arena, que no ano anterior, 1958, havia montado Eles Não Usam Black-Tie, de Gianfrancesco Guarnieri e que neste ano de 1959 apresentava A Revolução da América do Sul, de Augusto Boal. Seria também, neste ano a montagem de outra peça de Gianfracesco Guarnieri, Gimba, Presidente dos Valentes, pelo Teatro Popular de Arte, de Maria Della Costa.

Não obstante o resgate do autor nacional, Arthur Azevedo ia na contramão dos textos encenados. Uma peça de muitos atores, que previa muitos cenários, além das partes musicadas, com necessária contratação de músicos para sua execução era difícil de ser imaginada. Além do mais, a peça já havia sido montada alguns meses antes, resultando num enorme fracasso.

Uma nova fase, porém estava se iniciando. Era a criação do Teatro dos Sete, e o grupo buscava um texto que marcasse sua estréia como Companhia. Ao ler o texto de Arthur Azevedo, Gianni Ratto acreditou ter encontrado a peça ideal para este momento, afinal O Mambembe é a história de uma companhia itinerante que tenta sobrevier de qualquer maneira às dificuldades para fazer teatro, o que era a realidade pela qual passavam.

Sobre a escolha do texto Gianni Ratto nos conta em seu livro A Mochila do Mascate:

"Quando li a peça, entre tantas outras disponíveis, ela me chamou a atenção não só por suas qualidades dramatúrgicas indiscutiveis mas também - e este foi um fator fundamental para a escolha - por ser ela um atualíssimo retrato da condição de quem, naquele momento, estava fazendo teatro: dificuldades para formar companhias, vedetismos incipientes, necessidade de perambular constantemente para encontrar uma sede de trabalho, mambembar para sobreviver, nenhuma, ou pouca, consideração para com a condição do artista (naquele periodo, e ainda durante bastante tempo, as atrizes eram obrigadas a ter uma carteira que as equiparava às 
prostitutas, tendo a obrigação, durante qualquer viagem de trabalho, de se apresentar às delegacias de polícia locais).

A peça, aparentemente singela, encerrava, e até hoje encerra, uma carga poética e um amor pelo teatro que, aliados a uma hábil carpintaria, garantiam um êxito quase indiscutivel". ${ }^{76}$

A produção era ousada, pois havia necessidade de diversos cenários, inúmeros figurinos, além de grande elenco e técnicos envolvidos no projeto. E tudo isso para um grupo que estava começando e não tinha capital necessário para uma grande montagem como esta. Mas mesmo assim eles acreditavam no trabalho de Gianni Ratto, na sua capacidade como diretor e comungavam com ele a encenação de grandes autores, de bons textos.

Sérgio Britto lembra que a idéia de fazer o espetáculo foi do próprio Gianni Ratto:

"Foi o Ratto que nos convenceu a fazer o Mambembe. Era a idéia de um espetáculo musical que nunca se tinha feito no Brasil. Eram oitenta e quatro pessoas em cena, cantando, dançando e representando. Nós éramos tantos que quando nós saímos do Municipal, onde ficamos quinze dias, fomos pro Copacabana nos reduzimos a sessenta, porque não cabiam dentro dos camarins os oitenta e quatro". ${ }^{77}$

O texto de Arthur Azevedo para a montagem do grupo teve uma leve adaptação, recebendo um prólogo e um epílogo especialmente encomendado a Cláudio de Mello e Souza. $^{78}$

A partir daí, o trabalho de pesquisa foi iniciado. Gianni Ratto percorreu vários imóveis do Rio de Janeiro, para se inspirar na concepção do cenário. Eram freqüentes também suas visitas à Biblioteca Nacional em busca de antigos jornais, entrando

\footnotetext{
${ }^{76}$ RATTO, Gianni. A Mochila do Mascate. Editora Hucitec. São Paulo. 1996. p289.

${ }^{77}$ Entrevista concedida por Sérgio Britto ao autor da dissertação, em agosto de 2006.

${ }^{78}$ Tanto o prólogo como o epílogo podem ser consultados na gravação original do espetáculo de 1959 conseguida pelo autor da dissertação e anexada ao presente trabalho. Nela, estão presentes os três atos do celebrado espetáculo de Arthur Azevedo.
} 
também em contato com Aluísio de Azevedo, sobrinho de Arthur, bem como com Raimundo Magalhães, que o auxiliou na busca documentária.

Obteve auxílio da parte musical com o famoso compositor Almirante, colecionador de textos e músicas populares, como também de Dona Oneida Alvarenga, folclorista conhecedora de modinhas, cantigas de roda, danças populares que Mário de Andrade, seu amigo, havia recolhido em coleções antológicas, enviando a Gianni, de presente, dois volumes da obra de Mário de Andrade nos quais música e arte popular estavam registradas cuidadosa, magistral e copiosamente.

Até mesmo o cateretêt ${ }^{79}$, dança folclórica mencionada no texto, praticada no interior do Brasil e difícil de ser encontrada a forma como era executada, foi descoberta por Renato Consorte, um dos atores da peça, através de um manual em que estavam compiladas, graficamente diversas danças folclóricas brasileiras, entre elas $\mathrm{o}$ mencionado cateretê.

Por fim, o Theatro Municipal, em virtude da comemoração de seu cinqüentenário, além de ceder os figurinos solicitados pelo grupo, executou também os desenhos de Napoleão Moniz Freire, bem como os catorze cenários desenhados por Gianni Ratto.

A formação do elenco foi o que deu mais trabalho, pois o texto pedia aproximadamente setenta atores. Como conseguiram atribuir a alguns atores mais de um papel, o número necessário caiu para cinqüenta, o que, ainda assim, era um elenco bastante numeroso. Muitos dos atores que faltavam vieram da Casa de Repouso dos Artistas. Assim, tiveram a sorte de descobrir pessoas que tinham sido representativas em épocas anteriores na arte brasileira, e que demonstravam uma vivacidade e uma lucidez mental que muitos dos jovens não possuíam.

\footnotetext{
${ }^{79} \mathrm{O}$ Cateretê é uma das danças mais genuinamente brasileira. É de origem indígena, tal qual o seu próprio nome, tirado da língua Tupi. É uma espécie de sapateado brasileiro executado com "bate-pé" ao som de palmas e violas. Tanto é exercitado somente por homens, como também por um conjunto de mulheres. O Cateretê é conhecido e praticado, largamente, no interior do Brasil, especialmente nos Estados de Minas Gerais, São Paulo, Goiás e, também, em menor escala, no Nordeste. Em Goiás é denominado "Catira".
} 
Tratava-se realmente de uma superprodução nunca antes vista. A estréia foi um retumbante sucesso. A direção de Gianni Ratto mais uma vez contagiou o público, como nos conta Sérgio Britto em seu depoimento:

"Não, foi uma direção, olha, memorável. Quando o Mambembe acabou, pra você ter uma idéia mais ou menos o Mambembe começou às nove horas e acabou quinze pra meia-noite. Duas hora e quarenta e cinco minutos, porque ele também não cortava peça. Nós ficamos no teatro até as três horas da manhã, porque quando acabou o espetáculo nós não tínhamos chegado aos nossos camarins e o público já estava no palco, praticamente metade da platéia desceu pro palco. Agora, metade da platéia do Municipal são mil pessoas. Todo mundo querendo saber, todo mundo querendo aprender as músicas, ver o cenário, ver os detalhes. Era uma coisa quase que absurda. " 80

Fernanda comenta do numeroso elenco do espetáculo:

"O Mambembe, ao todo tinha perto de oitenta participantes, entre a parte administrativa, entre maquinistas, entre o grupo de cateretê , o grupo de não sei que, mais um elenco enorme enfim, mais as camareiras,mais.... "81

A crítica consagrou definitivamente a montagem do diretor. A sua repercussão na imprensa foi excepcional, fora de qualquer padrão. A escritora e jornalista Zora Seljan, que mantinha uma coluna no jornal O Globo publicou como homenagem ao espetáculo, uma história em quadrinhos da peça. Em sua coluna ela dizia: " $O$ que aconteceu no final pode ser comparado com os grandes intérpretes musicais: a platéia aplaudindo, uns rindo, outros com lágrimas, entre alegres e comovidas, sem querer

\footnotetext{
${ }^{80}$ Entrevista concedida por Sérgio Britto ao autor da dissertação, em agosto de 2006.

${ }^{81}$ Entrevista concedida por Fernanda Montenegro ao autor da dissertação, em agosto de 2006.
} 
deixar o lugar, só fazendo questão de continuar a aplaudir, numa demonstração de entusiasmo que as platéias de teatro não costumam ter. ",82

Fundamental o depoimento da crítica Bárbara Heliodora que presenciou esse momento mágico da estréia do espetáculo:

"O Mambembe foi inesquecivel, eu me lembro do Mambembe como se estivesse passando na minha frente, ao vivo e a cores. Porque foi o uma coisa inacreditável. Eram 14 cenários. Cada cenário que aparecia o teatro vinha abaixo de aplausos, porque era uma coisa inacreditável, o primeiro era o fundo do armazém, onde eles se encontravam, era maravilhoso... Tinha réstia de cebolas, tinha isso, tinha aquilo tinha caixote, e............Tudo pintado, pura cenografia italiana. Mas no final tinha a Festa do Divino com o "coiso" de bambu, o coreto. Era uma coisa maravilhosa. Tinha tudo, e tinha o bonde que vinha de Santa Tereza que o Ítalo... o bonde saía correndo e o Ítalo ia atrás para pegar o trem, e andava... E a minha impressão da estréia do Mambembe é que foi uma coisa tão extraordinária de alegria, de olha que coisa linda que eu sempre digo que as pessoas se encontravam no intervalo se encontravam e diziam "Como vai você? Você está bem? (sempre rindo) Porque era contagiante a alegria do espetáculo. E o espetáculo acabou... o que? Umas onze e meia, ou algo assim e eu me lembro que só saímos para jantar, porque eu saí com eles, do teatro, já passava de duas horas. O que tinha de gente pra cumprimentá-los era uma loucura. Foi um marco. Só sinto que não haja o DVD do espetáculo, porque era uma aula do que deveria ser feito para montar o Arthur Azevedo. Era realmente, figurino, cenário, interpretação, tudo, tudo, tudo. Era uma coisa maravilhosa, e foi ...O Ratto é quem dizia: Mas era nosso cartão de visitas, a primeira coisa do Teatro dos Sete. Então tinha que agradar. Então foi! Mas que cartão de visitas! Foi sensacional! ",83

\footnotetext{
${ }^{82}$ BRITTO, Sérgio. "Fábrica de Ilusão - 50 Anos de Teatro" -Salamandra - Funarte. 1996. pág.108

${ }^{83}$ Entrevista concedida por Bárbara Heliodora ao autor da dissertação, em agosto de 2006.
} 
Para finalizar essa digressão sobre a referida montagem de $\mathbf{O}$ Mambembe, vale transcrever as palavras de Sérgio Britto, citando também o crítico Sábato Magaldi, em seu livro auto-biográfico, a respeito da direção de Gianni Ratto:

"Sábato Magaldi no seu Panorama do Teatro Brasileiro afirma que O Mambembe é dos mais completos espetáculos já realizados no Brasil. É aí o momento de falar de Ratto e de sua extraordinária direção, na medida justa, popular e requintada, dominando o humor bem carioca dos tipos de Arthur, com a brejeirice afrancesada da partitura musical, sem falar da sua cenografia, puro teatro de revista, com telões subindo e descendo. A locomotiva que levava a companhia dos mambembeiros na sua viagem para o interior do Brasil era inesquecivel, desses momentos de teatro que ficam na memória. Eduard, meu personagem, chegava atrasado e pegava o trem andando. A ilusão era perfeita. " 84

O Mambembe tinha em seu elenco os seguintes atores: Fernanda Montenegro, Grace Moema, Ítalo Rossi, Sergio Britto, Renato Consorte, Waldir Maia, Iara Cortez, Iolanda Cardoso, Zilka Salaberry, Aldo de maio, Alan Lima, Armando Nascimento, Cavaca, Labanca, Milton Carneiro, Napoleão Moniz Freire, Tarcísio Zanotta, entre muitos outros.

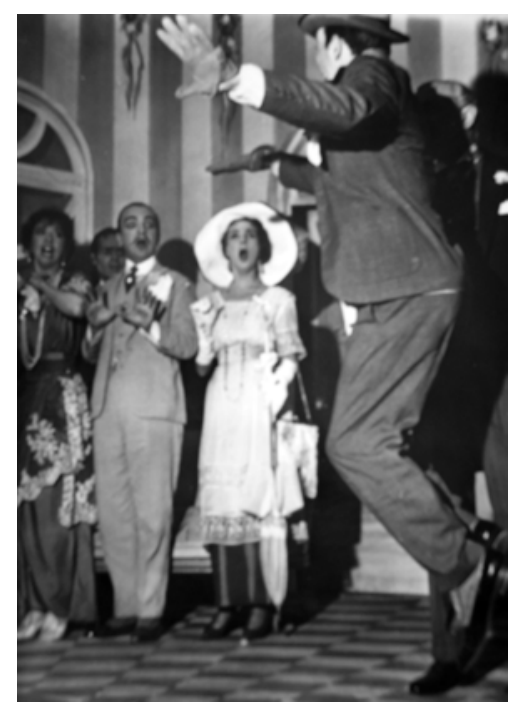

Iolanda Cardoso, Napoleão Moniz Freire, Iara Cortez e Ítalo Rossi

O Mambembe - 1959 - Direção Gianni Ratto

\footnotetext{
${ }^{84}$ BRITTO, Sérgio. "Fábrica de Ilusão - 50 Anos de Teatro"-Salamandra - Funarte. 1996. p.108
} 


\section{O Amor pela Ética: Gianni Ratto.}

Talvez seja um pouco poético para uma dissertação, mas antes de se passar às conclusões finais, onde será abordado, efetivamente, e na medida do possível, todo o processo de direção em que Gianni acreditava, uma vez que o conhecimento obtido dele por aqueles que com ele trabalharam, ou com ele conviveram, é incomensurável, vale justificar o título deste capítulo - Quatro Formas de Amar (ou O Amor em Quatro Tempos) - da seguinte maneira:

As quatro fases da lua (nova, cheia, minguante e crescente) - a essência da noite. As quatro idades do homem (infância, juventude, idade adulta e velhice) - a essência do homem.

Os quatro elementos (terra, fogo, água e ar) - a essência do universo. As quatro estações (primavera, verão, outono e inverno) - a essência da terra. Os quatro tipos de amor (pátria, terra, profissão e ética) - a essência de Gianni Ratto. 


\section{CAPÍTULO IV - CONCLUSÃO}

\section{IL MAESTRO - A REGÊNCIA DO ESPETÁCULO}

"Não adianta: do ator não se escapa; sozinho ou múltiplo ele é o teatro, a cenografia, o figurino, a sonoplastia, a luz, a sombra, a música, o canto, a palavra: o resto é pirotecnia, malabarismo, fogo de artifício. Afirmem o contrário e ficarei muito irritado."

Gianni Ratto

Gianni Ratto, indubitavelmente, foi um homem ímpar para o teatro. Não apenas para o teatro brasileiro, mas com certeza para o teatro mundial. Influenciado em seu modo de trabalhar por pessoas como Gordon Craig, Giorgio Strehler, Igor Stravinsky, Paolo Grassi e Dario Fo, com os quais manteve amizade. Não há como pensar nele como um profissional substituível. Sua excelência como cenógrafo, figurinista e iluminador já está mais do que comprovada. O que se dirá então de sua atuação como diretor? Claro está, nesse ponto do trabalho, após terem sido percorridas essas sinuosas vias de sua carreira, e de sua vida, que seu trabalho como diretor, como mestre das artes cênicas engloba todas as outras atividades aqui já citadas.

Se o nome de Gianni Ratto, infelizmente, não se afirmou como diretor da forma "espetaculosa" como a de alguns "encenadores" festejados pelo grande público, e até mesmo junto aos novos "atores" e candidatos a atores que despontam (e mesmo pela discutível "mídia"), não foi por falta de capacidade, por incompetência. Muito pelo contrário, isso se deve, em grande parte, ao fato de Gianni, na sua característica humildade, que deveria ser inerente a todo homem de teatro, e que era parte intrínseca de sua personalidade, não deixar que seu nome se sobrepusesse ao espetáculo que ele conduzisse.

Como um verdadeiro "maestro", um chefe de orquestra, Gianni sabia que para dirigir um espetáculo, ele, como diretor e participante de sua engrenagem, deveria se diluir dentro de sua essência. Sua função era captar toda a informação contida no texto, transmitida pelo autor a ser encenado e, dessa forma, se tornar um catalisador de suas idéias, fazendo-as tocar o público, tendo os atores como fios condutores desse processo alquímico. 
Diversas vezes Gianni falou, seja em conversas, ou através de escritos que publicou, que o que mais importava dentro da montagem de um espetáculo era o entendimento do texto por parte do ator. Quanto mais informação o intérprete tivesse da época em que se desenrola a cena, dos costumes do local onde se desenvolve a ação, da forma de vestir e de se portar da personagem que ele irá interpretar, tanto mais ele poderá compreender o caminho que o diretor propõe como forma de revelar a palavra do autor do texto.

Não é à toa que grandes "monstros" do teatro como Fernanda Montenegro, Sérgio Britto, Nathalia Timberg, Ítalo Rossi, Cleide Yáconis tenham já declarado muitas vezes, a fundamental importância de Gianni Ratto em suas carreiras e em suas vidas. Não apenas profissionalmente, mas também como exemplo de disciplina, perseverança e renovação em qualquer área de atuação.

São palavras da própria Fernanda Montenegro:

"Eu e Fernando (Fernando Torrres), nós fomos duas pessoas, assim... Feitas pela cabeça do Ratto, porque nunca deixamos de reconhecer nele o homem extraordinário de teatro que ele foi."(...) (...) “O Ratto me deu consciência, a visão altamente artística, a utopia também para o teatro, e algo que sempre está além que a gente vai alcançar daqui a pouco, e não pára de procurar porque todo dia a gente se experimenta e se propõe." 85

O próprio Sérgio Britto também fala da importância de Gianni na sua carreira, levantando lembranças de outros espetáculos por ele dirigidos, e que também tiveram grande significado para o teatro brasileiro. Ele diz:

"Eu acho que o Gianni foi o homem que me ensinou o amor ao teatro, o respeito ao teatro, aquele que nunca escolhia entre a versão dele e a versão que ele achava a mais correta. A versão mais correta é a que devia ser feita. A versão que mais dava ao autor a sua verdade mais absoluta, essa é que devia ser feita. Ele era chamado

\footnotetext{
${ }^{85}$ Entrevista concedida por Fernanda Montenegro ao autor da dissertação, em agosto de 2006.
} 
por muita gente de quadrado por isso, mas isso não é verdade, isso é uma coisa injusta. O Gianni era um corretíssimo diretor de espetáculo e de atores. Ele fez espetáculos inesquecívies, não posso falar no Mambembe, sem falar em Eurydice, Nossa Vida com Papai, ele fez Buonaventura, fez Moratória, ele descobriu Jorge de Andrade. É um espetáculo que todo mundo tem feito, nunca ninguém se aproximou nem ligeiramente da pureza e da simplicidade de Gianni. ",86

A preocupação de Gianni Ratto com o entendimento do texto, e a discussão da peça com os atores, de seus pontos de intersecção, de compreensão geral do teor do texto dramático eram fundamentais para o levantamento do espetáculo. Ele foi um dos primeiros diretores a entregar o texto inteiro para que o ator conhecesse a peça na sua integridade, uma vez que comumente era apenas entregue aos atores as partes em que suas personagens entravam em cena, onde estavam anotadas suas falas. Dessa forma, não tinham conhecimento de toda a estrutura dramática que representariam.

É Sérgio, novamente, que fala sobre a importância do trabalho com o texto, para o diretor:

"Quando o Ratto chegou aqui no Brasil, a primeira coisa que aconteceu ele inventou um verbo, como bom italiano que era, ele não encontrava a palavra e inventou um verbo "repeguemo", repeguemo. "Repeguemo essa cena". Agora, ao mesmo tempo ele foi para nós uma grande surpresa. Nós estávamos acostumados a ensaiar como? Lia a peça e no dia seguinte já estávamos marcando, movimentando. Com ele, eram dois meses na mesa lendo detalhadamente tudo. Explicando o autor, a filosofia do autor, o pensamento político e social do país, a moda, e como as pessoas usavam aquelas roupas daquela época. Olha que loucura. Quando se levantava da mesa, depois de dois meses, depois do ensaio, já estava pronta a peça. Você já tinha incorporado tudo. Estava prontinho pra fazer a peça. Agora,

\footnotetext{
${ }^{86}$ Entrevista concedida por Ségrio Britto ao autor da dissertação, em agosto de 2006.
} 
nunca isso foi, no início um embaraço para nós com o Ratto. $\boldsymbol{O}$ Canto da Cotovia, fizemos A Moratória que foi uma grande descoberta dele estar dirigindo o Jorge Andrade, foi A Pulga Atrás da Orelha". 87

Gianni sabia óbvia a subjetividade do autor do texto dramático e, portanto a necessidade de ser objetivo com sua obra, bem como também óbvia a subjetividade do leitor de um texto dramático. Com a união de tantas leituras subjetivas sabia fazer-se necessário uma leitura mais objetiva do que o autor pretende dizer, embora no final da apresentação haja uma manifestação solidária por parte do público, que infelizmente como o próprio diretor dizia tenha o odioso hábito de aplaudir em pé todo e qualquer tipo de espetáculo, apenas por uma questão de convenção social. Onde está, para o ator, para o diretor, enfim para todo o espetáculo o termômetro que antigamente refletia, nessa ação dos espectadores, o grau de entendimento do texto realizado no palco? $\mathrm{Na}$ Grécia Antiga, quando o público não gostava de um espetáculo, ou da atuação dos atores, celebravam o seu descontentamento com salvas de tomates e outras frutas podres atiradas diretamente sobre eles (sem falar em outros elementos menos nobres). Ao contrário, em resposta a um belíssimo e comovente espetáculo, retribuíam com flores, ou aplausos acompanhados de batidas de pé no chão.

O espetáculo não pode ser confundido com Teatro. Há que se distinguir claramente sua diferença, e Gianni fala a esse respeito:

"Acho indispensável separar o conceito de Teatro do de Espetáculo: o Teatro é a essência, o Espetáculo é o perfume diluído, muitas vezes num péssimo álcool e sem um fixador positivo. O teatro é poesia, o Espetáculo é técnica que pode até chegar a ter um nível de poesia mas que inevitavelmente se diluirá dans l'espace d'um matin. O Teatro agita massas e pode até modificar a história de um país; o Espetáculo sacode uma platéia e não modifica nada. E assim por diante, poderia continuar mas deixo de fazê-lo certo de que a simplicidade da colocação encontrará fácil concordância por parte de todos aqueles que ao Teatro se dedicam honestamente.(...) (...) E o

${ }^{87}$ Id. 
ator, o diretor, a cenografia, o figurino em tudo isso? Parece-me indispensável distinguir a crônica da história. O TEATRO é a História, o ESPETÁCULO a crônica; estas personagens chamadas diretor, ator, cenógrafo, figurinista, iluminador, músico etc., são os componentes de uma crônica que muito tempo depois de suas existências passará a ser história: a História destrói a crônica e quando esta, de uma forma ou de outra, consegue sobreviver se transforma em anedota: não preciso exemplificar. " $\$ 8$

Segundo ele o mais válido para a estruturação de um espetáculo era ter uma idéia condutora, ou mesmo um processo criativo que leve a esta idéia, devendo a inspiração preceder a execução. E, nesse processo, o trabalho do ator, como intérprete e "ponte" de comunicação do autor com o espectador, guiado é claro pelo diretor, é de fundamental importância.

Para tornar mais clara essa importante função do trabalho com o ator, Gianni procurava utilizar diversas formas de estímulo para sua criação objetivando que o ator assimilasse mais claramente sua personagem. Dizia mesmo que

"a criatividade não é algo espontâneo, que surja maciamente por uma solicitação onírica: a criatividade é sempre a conseqüência de algo que, incrustado no subconsciente, provoca um encadeamento de imagens, de idéias e propostas convergentes". 89

E mais, quanto ao intérprete:

"o caminho do intérprete é a busca permanente na insegurança do pensamento em constante evolução. É evidente que há atores e atuantes; criadores e repetidores; instrumentadores e orquestradores. $O$ ator é um instrumento complexo, confuso; é um emaranhado de elementos conflitantes no meio dos quais tenta organizar-se provocado

\footnotetext{
${ }^{88}$ Ratto, Gianni - A Mochila do Mascate. Editora Huicitec. São Paulo. 1996. p.73

${ }^{89}$ Ratto, Gianni - Hipocritando. Bem-te-vi Produções Literárias. Rio de Janeiro. 2004. p.30
} 
por palavras, emoções, gritos dilacerantes, perplexidades, nuanças e uma vontade infinita de se afirmar. "90

Sua forma de trabalhar era, desde o início, muito distinta da de seus colegas estrangeiros. Como lembra Fernanda Montenegro:

"Ele não era como o Ziembinski, que falava o que queria, Ziembinski representava. O Ziembinski era um homem extraordinário, mas era um ator extraordinário também. Então, ele dava a fala. Ele queria que o ator repetisse o tempo dele, e os tempos dele, entende. $O$ Ratto não, o trabalho do Ratto era estimular o teu imaginário, a tua sensibilidade e achar o teu cerne a serviço da cena. Completamente diferente! O Ziembinski seria quase que por mimetismo. $O$ trabalho do Ratto não! O trabalho do Ratto era você entender pelo sentimento e pela razão o que ele estava pretendendo, o que ele estava buscando. ${ }^{, 91}$

Durante as poucas conversas havidas com Gianni Ratto, em função de seu já frágil estado de saúde, ele lembrava sempre o papel do ator dentro de um espetáculo. Batia na tecla que, comumente parece um chavão ao jovem ator iniciante; a máxima levantada por Stanislavsky de que não há pequenos papéis, mas sim pequenos atores. Para comprovação deste epíteto usava como exemplo, de forma repetitiva, a participação de uma atriz que apenas "passava" durante a encenação de Eurydice, de Anouilh, na montagem realizada por ele no TBC.

Conforme suas próprias palavras, o magnetismo da atriz era tanto, era tal a intensidade de sua interpretação, que não havia como não se esquecer daquele mágico momento. Essa atriz de quem tantas vezes ele falava era Fernanda Montenegro, e ela recorda esse momento:

"Eurídice eu fazia nada. Mas tem uma hora que ela prenuncia a morte do herói. Essas coisas, ele te dava. Então não é só dizer... Se

\footnotetext{
${ }^{90} \mathrm{Id}$.

${ }^{91}$ Entrevista concedida por Fernanda Montenegro ao autor da dissertação, em agosto de 2006.
} 
não me engano a frase era: Fulano, o nome não me lembro agora, o trem acaba de chegar, o trem está chegando. Eu tinha que entrar em cena, uma das atrizes da companhia, e dizer ao herói que era o, o... fulano, o trem está chegando. E saía. E ele vai morrer naquele trem. Compreende? Tinha que chegar simples e criar uma coisinha, um ruído na cena, compreende? Mas isso porque ele nos deu isso. Porque ele me deu isso, compreende? Eu sou eternamente grata a ele. Era rigoroso. " 92

Este exemplo apenas comprova a teoria da importância do ator na defesa de seu trabalho individual, no trabalho realizado com a sua personagem. Daí se perguntar o que realmente seria um primeiro papel? A resposta é dada pelo próprio Gianni Ratto:

"Um primeiro papel é um detalhe dentro do espetáculo, que o ator transforma em algo irrepetível e antológico; é um momento único que tira o fôlego do espectador e o reconcilia com a vida; é um momento mágico que transforma a cena incandescendoa; é o gesto definitivo que nunca poderá ser reproduzido enriquecendo a atmosfera de um teatro que, quando vazio, agredirá o visitante deixando-o atônito e fascinado. "93

A preocupação de Gianni com o ator era muito clara, muito definida, ele sabia que era o ator quem deveria levar a idéia do autor do texto diretamente ao espectador, e para isso não esperava que se fizesse uma mágica, acreditava no trabalho, no exaustivo trabalho do ator baseado em muita pesquisa, exercício físico, força de vontade, e interesse. A propósito disso vale lembrar sua memorável montagem de Festival de Comédia, ainda no Teatro dos Sete, onde eram representados, numa única sessão três textos de autores diversos, quais sejam Ciúmes de Um Pedestre, de Martins Pena, O Médico Volante, de Molière, e O Velho Ciumento, de Miguel de Cervantes.

Sérgio Britto também lembra o espetáculo, falando da composição das personagens, e do trabalho corporal que tinha que realizar para sua construção, em três tipos diversos de texto, de autores distintos. Ele relata:

\footnotetext{
92 Id.

${ }^{93}$ Ratto, Gianni. A Mochila do Mascate. Ed. Hucitec. São Paulo. 1996. p.257
} 
"Porque ele fez os três estilos. Ele fez a comédia sofisticada do Cervantes, popularesca, grossa, mas sofisticada de certa modo. Fez um Molière requintadíssimo. Eu e o Ítalo (Ítalo Rossi) tínhamos uma cena em que nós nos cumprimentávamos sessenta vezes antes de começar a falar. Sabe o que é fazer sessenta vezes o movimento de capa, assim pra baixo..(faz) Quando eu saía daquela coisa eu caía sentado na cadeira, ai tinha que preparar correndo pra fazer o Martins Pena (Ciúmes de um Pedestre) onde eu era o protagonista, tinha que tirar toda a maquiagem e botar barba, bigode, tudo. Uma vez cheguei perto do Gianni e disse: - Gianni, você não acha que podia dar o papel do advogado pra uma outra pessoa? Olha ele, bem Gianni Ratto: - Não, se vocês quiserem a gente monta outra peça, noutra peça vocês não fazem isso. Eu estou dando a vocês a chance de vocês provarem que são capazes de fazer três estilos diferentes. Agora se vocês não quiserem...." 94

E eles queriam. E como queriam! A importância da pesquisa, da composição da personagem é lembrada, em relação à mesma montagem por Fernanda Montenegro. Ela diz:

"Em torno daquela problemática você lia. Eu me lembro hoje ainda, que quando a gente foi fazer o Cervantes, ele trouxe um livro de pintura do século de ouro do teatro espanhol, e também com a parte pictórica da época. Aquilo imediatamente você percebe Ele trouxe e disse: Olha aqui essa figura, essa aqui, aí você vai e procura. Você começa a colocar seus livros, você se intera, você vai ver como eram as roupas, como era a sociedade, como era do ponto de vista, outros autores, envolta daquela problemática, toda uma base cultural de informação. Bom, isso não enriquece só a peça. Você, você abre espaço... O meu Deus que coisa linda, não é? Que coisa maravilhosa,

\footnotetext{
${ }^{94}$ Entrevista concedida por Sérgio Britto ao autor da dissertação, em agosto de 2006.
} 
como você se amplia, como você, enfim alcança, e aumenta a percepção pra outras coisas.

Pois é! Porque era o seguinte: o cenário é esse, o figurino é esse. Você não ia pelo facilitário, assim, eu acho que aqui eu poria um chapéu assim, eu acho que não, é melhor diminuir esse degrau aqui, eu poderia entrar por aqui, em vez de por ali? Você co-dirige.... Uma pessoa que diz é isso aqui, e vamos fazer isso aqui, não é mimetismo também. E é um desafio, porque você pode ficar um autômato, não é? Um boneco bem cuidado, ou então você vai pra vencer o desafio, e existir no desafio. Ele nos ensinava a existir no desafio. Quando a gente fez Cervantes, o Sérgio tinha que andar assim (ela mostra) e o Ítalo tinha que andar assim (ela mostra). Aquelas figuras de feira, aqueles desenhos do teatro da Espanha. Vai fazer isso agora. Era fantástico. É isso o que eu quero, e vamos fazer. É claro que para fazer isso você faz os exercícios, você faz um aquecimento, você esquenta sua voz, e ficou, e fez, e fizeram. Eu nem sei se tem materiais desses espetáculos... "95

A empolgação com que Fernanda fala de Festival de Comédia é realmente contagiante, mostra que foi mesmo um espetáculo de grande importância, principalmente dentro do Teatro dos Sete. São suas essas palavras:

Eu acho que o Festival de Comédia, foi o somatório do que o Ratto pretendia em matéria de teatro no Brasil aos cuidados dele, ele sendo o mentor do processo. Eu acho que desde a Cotovia, desses doze anos de vida com ele nesse nosso grupo, eu acho que, se houve um espetáculo que o realizou, onde ele trabalhou e ele conceituou o seu melhor foi o Festival de Comédia. ${ }^{96}$

Ela completa sua afirmação, falando da importância do espetáculo para o Teatro Brasileiro, e citando Décio de Almeida Prado. Assim ela continua:

\footnotetext{
${ }^{95}$ Entrevista concedida por Fernanda Montenegro ao autor da dissertação, em agosto de 2006.

${ }^{96} \mathrm{Id}$.
} 
"Foram três espetáculos, chamado Festival de Comédia, eu acho que é muito interessante. Porque sempre se acha que o melhor não está na comédia. Era um espetáculo rigoroso, três séculos de teatro. Três pequenas obras primas. E a gente conseguiu fazer, e toda noite representávamos aquilo, e às vezes duas vezes por dia, e não se sabia onde buscar tanta energia pra se jogar daquela maneira. Naturalmente em nós mesmos, e principalmente neste estimulador artístico que era Gianni Ratto. Não sei por que esconder esse trabalho. Talvez Sérgio Britto tenha essa crítica do Décio dizendo que foi o único espetáculo nosso (do grupo) que foi a São Paulo. Que nenhum diretor brasileiro conseguiria dirigir um espetáculo como o Festival de Comédia. Eu não me lembro do resto da crítica, e na época foi muito interessante, já que a gente está falando de coração, nós achávamos que talvez na onda dos jovens diretores brasileiros, não é? Isso foi em 60........., 61, 62, seria talvez um espetáculo estrangeiro, compreende? De um, e não inserido na onda do jovem diretor brasileiro que está fazendo espetáculos brasileiros, ta entendendo? O que também é uma outra bobagem. Mas eu espero que eu leio, acho que conhecendo, não profundamente, mas bastante bem a crítica do Décio, eu acho que Décio fez um comentário muito, muito respeitoso e, realmente eu acho sim, que nenhum diretor naquela época conseguiria ter a disponibilidade, até mesmo cultural, para dirigir um espetáculo como aquele. Naquela época."97

Ainda se referindo ao mesmo espetáculo, a crítica Bárbara Heliodora nos fala também de sua qualidade cênica, mas principalmente daquilo que Gianni realmente acreditava, no espetáculo teatral, sem qualquer vaidade, ou mesmo preocupação em que o espetáculo fosse um espetáculo de "Gianni Ratto". Ela viu em Festival de Comédia uma verdadeira aula de como fazer teatro,

\footnotetext{
${ }^{97}$ Ibid.
} 
"Ah, esse foi uma aula de teatro. Uma aula de teatro. Era um Cervantes, um Molière e um Martins Pena. Foi fantástico. Uma coisa inacreditável.

Engraçado que naquela época se você perguntasse a 99\% das pessoas que iam ao teatro naquela época, ninguém falaria de Gianni Ratto, porque não tinha idéia do que era diretor. Especialmente porque Gianni era um diretor tão bom que não precisava fazer gracinhas pra dizer "Esse é um espetáculo de Gianni Ratto". Como acontece hoje em dia "esse é um espetáculo de fulano". O Ratto não, ele era um diretor maravilhoso. A direção melhor tem que passar despercebida. ",98

Gianni não se preocupava com que as pessoas, o público, soubesse efetivamente que ele era o diretor da montagem. Tanto isso é verdade, que ele não imprimia um estilo nas peças por ele apresentadas. Também não tinha a preocupação em repetir, ou insistir, na encenação de um determinado autor, ou gênero teatral para suas montagens. É o que Bárbara conclui a cerca de sua direção, citando Michel St. Dennis ${ }^{99}$ :

"Mas o Michel St. Dennis é que diz uma coisa muito boa. Que diz que uma vez ele falou de estilo e quase levou um murro. Porque as pessoas diziam que era uma coisa artificial. E ele dizia que não, estilo é fazer o que a peça pede. Então isso é o que o Ratto fazia é fazer o que a peça pede, não inventar uma gracinha do diretor. Colocar uma luz verde com uma luzinha amarela, não tem nada disso não. Ele não estragava o espetáculo, ele construía o espetáculo para chegar ao público. "100

Quanto a essa "preocupação" de alguns críticos e atores quanto ao "método" utilizado por Gianni para suas direções, era algo que de forma alguma lhe preocupava. Não sentia nenhuma necessidade em "desenvolver" esse tão propalado "método" que muitos diretores se apoderam como identidade própria, como ferramenta "personal" de trabalho.

\footnotetext{
${ }^{98}$ Entrevista concedida por Bárbara Heliodora ao autor da dissertação em agosto de 2006.

${ }^{99}$ Michel Saint-Denis (1897-1971) foi ator, diretor e teórico de teatro cujas idéias sobre o treinamento do ator tiveram profunda influência no desenvolvimento do teatro europeu a partir dos anos 30 .

${ }^{100}$ Entrevista concedida por Bárbara Heliodora ao autor da dissertação em agosto de 2006.
} 
"Muitas vezes me perguntaram qual é meu método de trabalho: não tenho método, talvez a minha maneira de trabalhar seja a soma de vários sistemas assimilados e digeridos para depois reaparecerem, informadores, indiretos de minha atividade. Cada espetáculo pede um sistema, cada texto exige uma postura crítica, cada ator determina um comportamento. Nada pior do que ter um sistema de trabalho pois ele levará inevitavelmente a uma rotina que, como tal, só poderá ser negativa.",101

Voltando ao cerne de nossa questão: o trabalho do ator na concepção de Gianni Ratto. Sua crença no trabalho do ator, trabalho efetivo, era muito grande. Para ele, o que importava era o interesse que ele demonstrava, sua força de vontade. Sua forma de ver a profissão do ator é bem clara quando diz:

“A profissão do ator é algo cada vez mais ameaçado: a técnica atua como elemento destruidor da criatividade; a indiferença leva a um nivelamento qualitativo equivalente ao de um cardápio no qual o sem-sabor é a tônica dominante; a preocupação do êxito, o medo do fracasso, a fofoca que leva ao sucesso social, ao saldo bancário referencial da subida na vida; o reencontro com a poesia cada vez mais afastado do sentido da vida; a vida algo a ser vivido e não gerenciado; redescobrir a sutileza de um perfume, constatar a presença acariciante da sombra provocada por um raio de sol; conviver com alguém que compartilhe as emoções de uma presença sensível disponível para todos, a serviço de todos; a redescoberta do sentido do coro como argamassa espiritual coagulante de temáticas universais... e o silêncio propiciador da palavra e do pensamento criativo... (ou investigativo?), a pausa como instante para uma rápida

${ }^{101}$ RATTO, Gianni. A Mochila do Mascate . Ed. Hucitec. São Paulo. p.210 
reflexão esclarecedora, o grito que acompanha a conquista de uma idéia fulgurante...",102

O trabalho com os atores, para Gianni, fundamentava-se num inevitável ato de sedução, centrado no eixo da atividade a ser realizada. Acreditava o diretor que cada um desses atores era um universo diferente que deveria ser explorado em toda a sua profundidade, suas contradições, de forma tridimensional, sendo esse trabalho de sedução nada mais do que o início da relação do ator com o espectador com o qual estabelecerá contato.

Gianni fazia uma analogia da relação ator/diretor com a de um casal, revelando que o exercício da dominação só teria como resultado o seu naufrágio. Dessa forma, ele refutava a visão daqueles que afirmam que a relação entre o diretor e o ator deva ser fundada no domínio que a autoridade do diretor, ou professor, exerça em razão da posição que ele ocupa, da pseudo sabedoria e "indiscutível" verdade da qual é dono e senhor.

Essa postura de "importância" indiscutível também vitimou Gianni Ratto, o que possivelmente tenha impedido que ele realizasse vôos ainda mais altos do que os praticados. A sua excessiva intransigência e excessivo rigor, no início de sua carreira como diretor, ancorados na disciplina férrea com que levava seus atores, obrigando-os a repetir nas apresentações exatamente aquilo que havia sido feito durante os ensaios, um dia despedaçou-se como um fino cristal. Essa mudança radical, essa volta à realidade só lhe foi permitida justamente pela ação de um ator, ou melhor, de uma atriz, Cacilda Becker.

Aconteceu durante os ensaios do espetáculo Isso Devia ser Proibido, de Walmor Chagas, que também atuava, e Bráulio Pedroso. Gianni algumas vezes comentou esse episódio, de tão marcante que foi para sua atividade profissional, e talvez até para sua vida. O diretor havia preparado uma cena em que Cacilda e Walmor "brincavam" com uma corda, que aos poucos ia amarrando o casal. Para sua efetivação,

${ }^{102}$ Ratto, Gianni - Hipocritando. Bem-te-vi Produções Literárias. Rio de Janeiro. 2004. p. 47/48 
definiu gestos e ritmos, dando todas as informações técnicas necessárias, acreditando ser tudo original e importante. De repente,

"no meio da execução do ensaio da cena, Cacilda parou e irritada e aborrecida gritou: "Por que? Quero saber o por quê! Você dirige, impõe e exige mas não explica o por quê. Eu preciso saber, não sou uma marionete que você possa manipular à vontade: sou uma atriz e preciso fundamentar a construção de minha personagem sobre informações, análises e não imposições”. Ela tinha razão. Eu não estava na minha prancheta de desenho organizando um projeto do qual somente eu era dono. O ideal de Craig, a idéia da "supermarionete" desfazia-se pelo mais do que justificado rompante de Cacilda. A partir daquele momento minha visão sofreu uma guinada que não somente envolveu meu trabalho como também uma visão de vida dentro da qual a minha "importância"deixou de ser indiscutivel.",103

De certa forma, isso possibilitou a Gianni, mais uma vez, refletir sobre esse trabalho conjunto que exercem diretor e ator para o bom resultado do espetáculo. Acordando-o para a individualidade do ator, lembrando-o mais uma vez que cada um deles possui característica própria, caminhos específicos para serem abordados, conquistados, seduzidos para que, de certa forma, sejam capazes de doar a si mesmo e, assim, poderem conquistar um pouco mais de sensibilidade e paixão através das vidas por eles vividas

O fascínio exercido pelo ator, através de sua concepção, do trabalho individualizado, é o que encantava o diretor. A possibilidade de conseguir, através dele, o contato com o espaço mágico de sua atuação, onde "flutuarão" climas e personagens, como momentos únicos impossíveis de serem revividos da mesma forma como foram apresentados. Um verdadeiro ato de amor, onde ele, o ator, independente de onde esteja situado, torna-se o centro do palco, banhado por uma luz que não vem do projetor, mas

${ }^{103}$ RATTO, Gianni. A Mochila do Mascate. Ed. Hucitec. São Paulo. p.238 
que dele emana, através de suas palavras ou do silêncio mais profundo que, inevitavelmente, torna-se verbo através de seu próprio reflexo interior.

Toda essa sua preocupação com o ator é resultado inevitável de uma relação amor/ódio. Isso fica bem claro quando Gianni nomeia porque ele ama e porque ele detesta este ser chamado ator.

"Detesto o ator por seu egocentrismo, seu narcisismo, sua incapacidade de penetrar fundo num problema que exija o sacrifício de parte de um resultado imediato; o detesto por seu cabotinismo que o leva a amar quem o bajula e a detestar quem o aconselha; detesto-o por ambicionar o sucesso fácil, o aplauso mentiroso, por usar uma máscara de muitas faces, por querer ficar no centro do palco roubando o papel do colega.

Mas eu amo o ator pela cega fé que o leva a entregar sua vida a uma atividade cruel e madrasta; o amo pelos momentos irrepetíveis de beleza e poesia que sabe criar independendo de sua cultura: por puro instinto, por uma sensibilidade que ninguém pode lhe dar, por ser como ele é com todos seus defeitos e limites mas com uma potencialidade da qual ele não se dá conta e que o conduz, orientado pela palavra do poeta, por caminhos nunca percorridos, cada vez diferentes, mais luminosos, esplêndidos e destinados ao esquecimento. Como o louva-a-deus, é devorado por sua ansiedade de amor.",104

Para Gianni, o fator observação era muito importante para que o ator pudesse construir sua personagem. A capacidade de observar, analisar e por que não dizer, amar é inerente à essência do ator, e para que ele atinja seu objetivo deve desenvolvê-la o máximo possível.

\footnotetext{
${ }^{104}$ Ratto, Gianni. A Mochila do Mascate. Ed. Hucitec. São Paulo. 1996. p. 239.
} 
"Teatro é diálogo; diálogo entre o autor e os atores que serão o trâmite entre ele e a platéia, e diálogo entre o ator e a personagem com a qual se defronta. Eu acho que o intérprete é um instrumento diria uma área - colocado à disposição de algo ou alguém, disposto ou não a ocupá-lo; o ator tem que se dar conta de que sua disponibilidade tem que ser total, física e intelectualmente, para poder ser invadido: penso que é a personagem que move o ator e não o contrário.", 105

Fica assim, mais do que clara a importância para Gianni Ratto desse trinômio autor/diretor/ator, sem o qual o Teatro não seria possível.

Como forma de finalizar, esse "esboço" de suas idéias e convicções, em forma de dissertação, vale deixar consignadas as palavras de Fernanda Montenegro e Sérgio Britto, sobre a importância de Gianni Ratto para suas carreiras de atores.

“... ele foi o nosso mestre, ele foi aquela pessoa que nos ensinou o que é o verdadeiro teatro. Eu trabalhei com pessoas como o Geraldo Thomas, com o... Victor Garcia, trabalhei com o Georges Lavelle, trabalhei com a Nely Frank, trabalhei com pessoas muito interessantes, sabe, mas e dai? Nenhum deles se aproxima sequer dele. É uma outra mentalidade. O Gerald Thomas inventa um espetáculo maravilhoso e depois faz um espetáculo detestável. E esse é o processo dele. O Gianni procurava seguir absolutamente o autor, mas as vezes a fidelidade total ao autor gera o fracasso, para o grande público.",106

"Eu e Fernando (Fernando Torres) nós fomos duas pessoas, assim... feitas pela cabeça do Ratto, porque nunca deixamos de reconhecer nele o homem extraordinário de teatro que ele foi.(...) (...)" O Ratto me deu consciência, a visão altamente artística, a utopia também para o teatro, e algo que sempre está além que a gente vai alcançar

\footnotetext{
${ }^{105}$ Ratto, Gianni. Hipocritando. Bem-te-Vi Produções Literárias. Rio de Janeiro. 2004. p. 130.

${ }^{106}$ Entrevista concedida por Sérgio Britto ao autor da dissertação em agosto de 2006.
} 
daqui a pouco, e não pára de procurar porque todo dia a gente se experimenta e se propõe.",107

Bárbara Heliodora vai mais além quando fala da importância do homem de teatro Gianni Ratto:

"Não tem dimensão. Como diretor, como cenógrafo e professor, ele contribuiu para a profissionalização do teatro. Porque eu acho que o problema é que você tem que deixar de ser amador para ser profissional. Porque esse culto do amador é pra quem fez teatro seiscentos anos, e tem um grupinho que vai não sei aonde e faz coisas. Nós precisamos é de profissional. É não se atrasar como se atrasa, que todo mundo seja responsável na hora de representar. Eu acho que o Ratto foi uma aula de teatro ambulante. Quer dizer eu acho que ele ensinou, foi um degrau no desenvolvimento do teatro brasileiro e ele fez uma contribuição monumental por ser bom cenógrafo, por ser bom diretor, por ser bom professor. Então acho que isso, quer dizer, nós devemos muito ao Ratto porque ele foi realmente..., e muito generoso na transmissão dos seus conhecimentos de maneira que tudo isso conta. Ele fez coisas realmente, ele deu grande contribuição. Ele era maravilhoso. Maravilhoso!! Esse ensinou muito!!! Vou lhe contar uma coisa linda do Ratto: Uma vez encontrei com ele e ele perguntou de um espetáculo que tinha estreado. E eu disse: Ah, é muito ruim. E ele: Puxa que horror, cada espetáculo ruim prejudica todo o teatro. Inclusive porque tira a platéia, porque quem vai a um espetáculo muito ruim não volta durante muito tempo ao teatro. E então ele disse assim, é uma pena as pessoas precisavam lembrar que cada espetáculo afeta toda a atividade teatral.

Ele tinha consciência de que tudo era importante.

\footnotetext{
${ }^{107}$ Entrevista concedida por Fernanda Montenegro ao autor da dissertação em agosto de 2006.
} 
Jean Louis Barrault disse a coisa mais maravilhosa que já ouvi na vida, fazendo uma palestra aqui no Theatro Municipal, ele disse assim: Para ser ator é preciso que se tenha uma razão mais forte do que querer encontrar uma profissão que se acorda mais tarde. "108

Vale mais uma vez afirmar que é muito pequena essa amostra da efetiva importância do diretor Gianni Ratto para o teatro brasileiro. Haveria muito mais a se falar sobre sua paixão, seu amor pelo teatro, e a forma como conduzia suas montagens. Mas há ainda muito a ser trilhado e descoberto sobre seu processo de trabalho alquímico que permitia o encontro do ator consigo mesmo e com todos os outros seres que convivem, ocultos, navegando por artérias e poros de seu corpo, a espera de uma provocação causada pela palavra escrita para que possa traçar sua viagem de deliciosas e surpreendentes aventuras a fim de conquistar, verdadeiramente, o coração e a alma de seu mais desacreditado espectador.

A seguir será apresentado um texto, inédito, de Gianni Ratto, escrito provavelmente na década de 60 , transcrito a partir do original datilografado, retirado de seu acervo pessoal, em que ele fala da importância do diretor estrangeiro no Brasil.

Mas antes vale registrar algumas palavras finais de Gianni sobre ele mesmo:

"Olho do alto de minha mediocridade e me regozijo: os outros que se fodam; sou o que sou e me fiz sozinho, não devo nada a ninguém... Não é verdade, devo tudo a todos, mas sou mal-agradecido."

Gianni Ratto

${ }^{108}$ Entrevista concedida por Bárbara Heliodora ao autor da dissertação, em agosto de 2006. 


\section{A CONTRIBUIÇÃO DO DIRETOR ESTRANGEIRO AO TEATRO BRASILEIRO}

O primeiro grande teatrólogo estrangeiro a chegar ao Brasil foi Anchieta que trazia consigo a tradição cultural jesuíta das representações sacras e profanas da Europa.

Sua influência - consideradas as características de seus espetáculos nos quais a música, a dança e o texto falado em prosa e a poesia se misturavam - pode ser notada ainda hoje, paradoxalmente falando, no interesse que determinadas camadas de espectadores demonstram para as atrações que as várias praças tiradentes do país oferecem.

O palavrão, uma das grandes razões de polêmica hoje (dizer ou não dizer?) também tem um predecessor europeu, embora nascido aqui no Rio de Janeiro: Antonio José, melhor conhecido como "O Judeu”. Por ser tal teatrólogo e concorrente, encontrou nos pios fazedores de espetáculos edificantes, seus inimigos que acabaram queimando seu cadáver de herege condenado pela Inquisição. O teatro tem suas vítimas em todos os tempos.

Em compensação, nossos índios, os da costa da Bahia, evidentemente ainda não catequizados por Anchieta, se vingaram antecipadamente devorando D. Pedro Sardinha, primeiro bispo enviado por Portugal, e o Vaticano, ao Brasil.

A Anchieta e ao Judeu, ao diabo e à água benta, portanto, pertence de qualquer maneira a responsabilidade do aparecimento do primeiro grande dramaturgo brasileiro: Gonçalves de Magalhães que ficará imortalizado justamente pela tragédia ( a primeira de nosso teatro) "Antonio José”, ou "O Poeta e a Inquisição". Na tragédia de Gonçalves de Magalhães, o Inquisidor, personagem reles, complexa e sórdida, acaba se arrependendo e se reconciliando com o poeta condenado. Pela lei das recorrências históricas, o mesmo deveria acontecer também hoje, entre censura e teatro. Mas pelo visto, é ainda cedo. 
Voltando ao nosso tema, muitas podem ser as razões que determinam o nascimento e a formação de um teatro nacional. Independentemente da presença de uma atividade propriamente dita (bons atores, bons espetáculos etc.) um teatro nacional só existe pela presença de seus autores, considerando - pelo momento - tais, somente os que contribuem com idéias, posições estéticas e intuições temáticas, etc. ao enriquecimento cultural, pela abertura de novas perspectivas e de um dimensionamento da problemática humana e nacional, sem o que não se poderá falar do teatro de um determinado país.

Entre as várias razões responsáveis pelo surgir de um movimento dramatúrgico, é fácil identificar a consciência do momento histórico e suas implicações com o passado e o futuro, a descoberta das personagens que o homem nacional contém, a presença de uma cultura em formação ou assimilada, os problemas político-econômico-sociais, os condicionamentos determinados pelos meios de comunicação de massa, a intolerância, o radicalismo, e a estupidez de certos governantes, etc., etc.

Agora, independendo dos movimentos mais recentes, parece-me que a dramaturgia nacional começa a se manifestar vigorosamente a partir da "Semana de Arte Moderna" de Mario de Andrade, cujas implicações e desenvolvimento todos nós conhecemos e ainda se fazem sentir.

Todavia, não é demais relembrar alguns dados que me parecem indispensáveis para uma melhor compreensão do problema.

Com a "Semana de Arte Moderna" realizada em fevereiro de 1922 no Teatro Municipal de São Paulo, organizada e promovida por Mario de Adrade, Oswald de Andrade, Guilherme de Almeida, Di Cavalcanti, Menotti del Picchia, Graça Aranha, e outros, colocou-se pela primeira vez a questão da independência cultural do Brasil, a sua desvinculação da literatura portuguesa. Foi um movimento mais destrutivo que construtivo, tanto que os verdadeiros frutos da semana d e22 surgiram com o Romance de 30, que é o regionalismo nordestino: José Américo, Jorge Amado, José Lins do Rego, Graciliano Ramos e Rachel de Queiroz. 
Antes de 22, a literatura brasileira já tinha dado escritores caracterizadamente brasileiros como Machado de Assis, Lima Barreto, etc. Mas, como forma global de cultura, permaneciamo-nos na dependência cultural portuguesa. $\mathrm{O}$ movimento de 22 investiu mais exageradamente contra o ranço do "parnasianismo" (voltado aos modelos gregos) para propor uma arte brasileira na forma e na temática. Na época, o escritor que representava o "estilo vigorante" era Coelho Neto, extremamente rebuscado mas desprovido de conteúdo. Os "modernistas" chamavam seus seguidores como fazedores de uma literatura "coelhonetal" ou "nhen-nhen-nhen", termo tupi-guarani que quer dizer bla-bla-bla.

Como conseqüência da "Semana d e 22", surgiu o movimento Antropofágico, instituído por Oswald de Andrade e que assim se denominava por assinalar, como o primeiro ato de brasilidade aquela comilança dos índios da costa da Bahia que se regalaram com as carnes episcopais de D. Pedro Sardinha. Desse movimento, surgiu a pintora Tarsila do Amaral.

O próprio Oswald escreveu três peças que nunca foram encenadas. Somente agora o Teatro Oficina montou "O Rei da Vela" que se apresentada em 1935 acredito teria aberto novos caminhos à dramaturgia brasileira, acelerando seu processo evolutivo, por sua temática social e pela originalidade de sua forma. Está claro que, frente a estas qualidades, os órgãos oficiais não podiam ficar indiferentes e todos nós sabemos das colheres de pau e de chá que foram gastas em prol da cultura nacional.

O Teatro de Oswald de Andrade prenunciava já o de Nelson Rodrigues.

Se as antigas companhias itinerantes de Leopoldo Froes, Procópio Ferreira, Oduvaldo Viana montavam textos nacionais, vale dizer que se tratava de peças ligeiras e circunstanciais. A prova está no fato que pouco pesava na balança da cultura nacional: comedinhas de costume que não conseguiam (embora não desprovidas de qualidades) equiparar-se aos modelos deixados por Martins Pena e Arthur Azevedo.

De outro lado, e fazendo um parênteses, é necessário não esquecer que há um tipo de dramaturgia que encontra seus correspondentes em autores como Lindsay e Crouse, Marcel Achard, Casona, Roussin, etc., , que não deixa de ter a sua importância 
no contexto de uma dramaturgia da qual é o indispensável complemento: autores como Silveira Sampaio, Guilherme de Almeida, Abílio Pereira, Pongetti, certas peças de Millor Fernandes, Magalhães Junior, João Bittencourt e outros que, embora guardando ou não certos dados urbanos ou nacionais em termos de sátira ou de temática histórica ou mitológica, não deixam de ter sua incontestável importância pela vivacidade do diálogo, pelo domínio da técnica e pelo brilho que caracteriza temas e invenções.

Fechado o parêntesis, ainda a meu ver, a conscientização do homem brasileiro proposta pela Semana de 22 veio atingir o romance da década de 30 e o teatro a partir de 1945-48. É curioso notar-se como, por exemplo, Jorge Andrade, que ficou evidentemente influenciado pelos espetáculos do TBC (praticamente todos montados por diretores estrangeiros, diga-se de passagem), tem uma vocação de romancista que enveredou pela de autor teatral, o que faz pensar que se uma civilização do espetáculo tivesse existido antes, talvez bem maior teria sido o número de autores anteriores a este período.

Portanto uma fundamentação cultural nacional é a que determina o surgir do teatro brasileiro e seu desenvolvimento.

Está claro, que, além de todas as solicitações que transcendem o mero interesse imediato de uma aventura financeira, a formação de uma consciência social coletiva poderá ser uma poderosa mola propulsora para o surgimento de novos autores. Oswald de Andrade, Joracy Camargo, Álvaro Moreira e Nelson Rodrigues serão os autores que darão início oficialmente à dramaturgia nacional.

De outro lado, de que valeria a presença dos autores se eles não fossem representados? Afinal, também em teatro, nasceu antes o ovo ou a galinha? Em nosso caso, nasceu antes o autor ou o espetáculo? Foi o primeiro que determinou o segundo, ou vice-versa?

Um ator como Procópio Ferreira identificando-se com a personagem de "Deus lhe pague" determinou o sucesso desta peça e isso fez com que outros autores se sentissem estimulados a escrever. Isto é bom, não há dúvida. Mas penso que é pouco. Escrever é como pintar ou exercer qualquer outra arte: é uma exigência interior 
imprescindível que somente depois se coloca o problema de um comércio que, afinal de contas, dependendo de seus resultados é a melhor prova de um êxito alcançado. Pelo menos, quase sempre.

Não há dúvida que aos autores se poderia imputar a responsabilidade de não escrever e o fato de se ausentarem do palco das atividades culturais do país. A desculpa de não existência de um teatro profissional qualificado, o divórcio das atividades teatrais internacionais, o desconhecimento (pelo menos em termo de ampla aplicação) da evolução do teatro nos outros países, a utilização por parte dos empresários e dos tradutores da mais medíocre literatura teatral estrangeira a benefício de um borderô fácil, são todos fatores que explicam em parte porque os autores não se empenharam suficientemente.

Mas eu penso que o contrário poderia se ter dado somente a partir do momento no qual uma consciência coletiva conseguisse ser captada pela sensibilidade de um criador.

Quero esclarecer uma coisa: cultura para mim, não é sinônimo de erudição. A cultura é um fenômeno espontâneo e ancestral que o homem carrega consigo e que lhe permite existir, e não vegetar. Há uma estratificação de valores que faz com que um homem se identifique nos outros e viva para os outros. Há um dimensionamento interior que leva o homem a viver heroicamente sua vida contra a mediocridade do meio comum. Há uma sensibilidade antiga que faz com que a piedade e o senso estético pertençam tanto ao mais humilde como ao mais beneficiado; tanto ao mais erudito como ao mais desprovido de instrução.

Há condições, quero dizer, de cultura - às vezes - propriamente lá onde menos poderíamos prensar que elas existem. E lá onde elas estão elas produzem seus frutos. É principalmente dos valores populares mais autênticos que o teatro brasileiro surge. $\mathrm{O}$ mamolengo, a literatura de cordel, a capoeira, o desafio, o candomblé, a nau catarineta, a chegança de marujos, os reizados, etc., etc., são teatro vivo, verdadeiro e autêntico que servirá como matéria prima maravilhosa, gemas para serem trabalhadas, para a dramaturgia nacional. Mas está evidente que seria pouco e facilmente esgotável um material tão extraordinário como esse para a presença do autor nacional. Todavia isto 
não deixa de ser um lastro cultural, esta é uma sólida base sobre a qual se construir algo. E, parece-me evidente, que assim como existe um folclore regional, também existe um folclore urbano. É só identificar o processo porque uma reação em cadeia se determine.

É justamente da piedade humana, no sentido mais profundamente cristão e social do termo, que surge a intuição, primeiro tímida depois violentamente agressiva, dos temas da dramaturgia brasileira. A visão da miséria dos retirantes, o castigo da seca, o destino duro enfrentado com humildade e resignação pelos tantos severinos, a omissão do poder, a revolta contra as injustiças sociais e o amor pelo homem, levam autores e poetas a escrever textos de uma beleza e de uma revolta que não podem passar desapercebidos. O sentimento religioso de um povo, o resignado fatalismo de uma região, o sincretismo de raças e de religiões, que afinal de contas se identificam em valores superiores, intervem para sublimar uma intuição e uma inspiração de caráter dramático levando, no caso, o Brasil a possuir hoje um teatro que até a representação de "Vestido de Noiva" praticamente não existia.

O que me interessa estabelecer, para que não haja equívocos, é que a presença do diretor estrangeiro foi responsável somente em parte pelo desencadeamento deste processo e que na verdade foram os valores autenticamente culturais do povo brasileiro que determinaram seu teatro.

A descoberta das temáticas urbana com suas implicações trágicas por parte de Nelson Rodrigues engata diretamente com a tragédia do nordeste e com a estruturação socioeconômica de um país do qual a casa grande e a senzala são o símbolo que continua presente numa grande cidade como o Rio de Janeiro em seus quarteirões copacabanenses e em suas favelas.

A verdade é que se partimos do pressuposto que um teatro nacional existe em função de sua dramaturgia, o papel do diretor estrangeiro - embora não possa ser menosprezado - tem um peso mais provocatório que determinante. Porque, a verdade deve ser dita, a maioria dos diretores estrangeiros que aqui vieram se preocuparam mais em trazer aqui um teatro europeu do que tentar estruturar um teatro brasileiro. Não fosse o excepcional valor de atores como Cacilda Becker, Paulo Autran e muitos outros que pertencem ao primeiro momento de renovação do espetáculo teatral brasileiro, hoje nós 
teríamos a continuação do fenômeno pelo qual os atores até um certo período representavam com sotaque português, somente que agora representariam com sotaque italiano, polonês ou francês. Posso estar exagerando um pouco, mas é inegável que quando se declarava com certo orgulho um tanto provinciano (e quem dizia isso eram os críticos paulistas) que os nossos espetáculos nada tinham a invejar aos estrangeiros, é porque tais espetáculos se aproximavam mais à categoria técnica desses do que por suas próprias características nacionais.

Um teatro existe menos pela sua técnica e mais por seus valores poéticos e temáticos. O dia no qual o teatro daqui ficar tão bom a ponto de poder dar lições aos outros, será talvez um dia lamentável porque o caminho para o falso respeito às falsas tradições e aos academicismos rançosos estará aberto.

Por sorte, estamos ainda na fase da pesquisa e de seus erros vitais.

Mas, não fugindo ao nosso assunto, não podemos deixar de constatar que o diretor estrangeiro não deixou de contribuir, e positivamente, par ao teatro nacional. Vejamos:

1. na formação de atores

2. na formação de artistas especializados: cenógrafos, figurinistas, compositores musicais.

3. na formação de técnicos especializados: maquinistas, iluminadores, aderecistas, costureiras e alfaiates, sonoplastas.

4. na elevação do nível cultural dos participantes do espetáculo.

5. na elevação do nível do espetáculo

6. na formação de uma consciência do espetáculo.

7. na formação de uma consciência de equipe.

8. na formação de uma consciência crítica (em relação as reações da platéia e da crítica especializada).

9. na visão econômica dos problemas da produção

10. na constituição dos repertórios e conseqüente formação de uma dramaturgia nacional. 
Deixei por último este item por ser o mais importante e o que mais me parece ter sido insuficientemente tomado em consideração por todos nós.

Com efeito, a exclusão de um ou outro autor, representado de forma casual quando não cautelosa, a não ser os raros casos em que pela esperança escandalística ou por comprovada resultante financeira, se apontava gloriosamente para o "autor nacional", entre aspas, os autores nunca foram efetivamente solicitados por nós em termos positivos e, diria, provocatórios, visto que agressivamente afirmam nossa qualidade de bons profissionais.

Nossa atuação, portanto, frente ao grande surto desses últimos oito ou nove anos foi indireta. Quando, quer pela qualidade dos espetáculos, quer pelo aumento das platéias, quer pelo exacerbar das situações internas do país, a gente de teatro começou a sentir a necessidade de expressar em altos brados seus pensamentos e suas convicções, nós, salvo esporádicas intervenções, nos fechamos um pouco na "turris ebúrnea" de nossos malabarismos profissionais.

Depois de Jorge Andrade, que continuou explorando seu tema base (o conflito das gerações em termos de campo-cidade), depois dos prenúncios sociais de Antonio Callado, depois das primeiras tímidas aparições de Guarnieri, Boal, Oduvaldo Viana Filho, etc. (autores estes últimos que realizaram o movimento do Centro Popular de Cultura ligado à União Nacional dos Estudantes, que se foi muito discutível nos resultados não deixa de ter uma série de motivações válidas), de repente é uma seqüência ininterrupta de autores que culmina com Plínio Marcos, o Zola brasileiro, que, sob o signo do palavrão, recebe a deixa diretamente do nosso falado e finado judeu.

Dias Gomes, Durst, o próprio Vianinha (que acaba de ganhar o prêmio do S.N.T.), Millor Fernandes, Suassuna, Bráulio Pedroso, Ferreira Gullar, Denois de Oliveira, João das Neves, fazem um teatro agressivo e muitas vezes de grande riqueza poética do qual deveríamos ter participado mais em profundidade.

Favorecer um a dramaturgia não é exatamente cultivar alguns autores como plantas raras e de estimação. Em volta delas devemos criar uma vegetação que seja a seiva que permitirá o surgir de uma grande floresta. A dramaturgia menor é 
indispensável. Em lugar de ceifar as plantas de pequeno porte para que as maiores apareçam, é indispensável ajudá-las a crescer.

Temos que fazer um teatro que esteja menos à procura da obra prima e mais em busca dos valores de contribuição que cada um pode trazer. Devemos menos procurar "o autor" e mais procurar "os autores"; precisamos dar às obras menores as mesmas condições de realização que oferecemos às maiores e às peças estrangeiras.

É um teatro fundamentalmente de protesto, às vezes violentamente agressivo, apoiado em descontentamentos, reivindicações e principalmente na exigência de uma liberdade sem a qual nem o pensamento, nem os direitos humanos, têm condições de sobrevivência e de respeito.

Para tanto, eu acho, nós demos muito pouco. Muito mais poderíamos ter dado se não tivéssemos tido receio (hóspedes como continuamos a nos considerar também por uma questão de mal entendida delicadeza) de nos deixar envolver mais num processo nacional que muito mais deveríamos ter considerado nosso. De outro lado, nossa função não se identifica necessariamente num "cheguevarismo" do teatro. Integrados a um país que merece ser amado pelo carinho com o qual sabe receber quem aqui veio para trabalhar de verdade e que nos oferece respeito e meios de subsistência, algumas vezes somos acusados de viver à margem dos acontecimentos. Pode ser. Mas confesso, eu, pessoalmente, não me sinto muito a vontade em atacar, e criticar porque, afinal de contas, estou morando em casa de amigos. E, todavia, da vida deste país me sinto participe e confio mais profundamente na contribuição que posso dar dentro de minhas possibilidades artísticas e técnicas e dentro de meus próprios limites, do que assumindo atitudes que poderiam desembocar na pergunta: "Mas, afinal, o que é que o senhor tem a ver com isso?".

Parece-me que hoje, no momento em que o teatro alcançou sua maturidade nacional através de alguns autores, o papel do diretor estrangeiro mais uma vez deve ser desenvolvido no sentido de potenciar com todos os seus meios a arte do espetáculo, a capacidade expressiva e criadora de seus participantes e de seus intérpretes. 
Favorecer uma dramaturgia não é exatamente cultivar alguns autores, assim como não se cria uma arte do espetáculo somente por meio de seus grandes atores, como se se tratasse de plantas raras e de estimação. Em volta delas devemos criar uma vegetação que seja a seiva que permitirá o surgir de uma grande floresta. A dramaturgia menor é indispensável. Em lugar de ceifar as plantas de pequeno porte ou deixá-las murchar ou guardá-las como recheio para buquês afim de que as grandes apareçam, é indispensável ajudá-las a crescer dando a elas as condições para um bom desenvolvimento.

Temos de fazer um teatro que esteja menos à procura da obra prima e do grande ator e mais em busca dos valores de contribuição que cada um pode trazer. Devemos menos procurar "O AUTOR”, “O ATOR”, “O CENÓGRAFO”, “O DIRETOR” e mais os autores, os atores, os cenógrafos, os diretores, etc. Precisamos dar às obras menores as mesmas possibilidades de realização que oferecemos às maiores e às peças estrangeiras e, da mesma forma, criar oportunidades para todos e não para poucos privilegiados, não esquecendo que o homem tem direito de pedir a seu trabalho que lhe devolva em dignidade econômica o que ele deu em desgaste físico, inteligência, sensibilidade e cultura.

Não se trata aqui de ser mais realista do que o rei, mas acho que temos, como primeira atitude a ser tomada, de esquecer o complexo de subdesenvolvido que, por sinal, é muito cômodo para os preguiçosos e para os que tiram vantagem dessa narcolepsia moral. Temos que completar uma ação que despertando definitivamente em todos a consciência de seus valores, faça surgir também uma capacidade autocrítica sem a qual se cairia no excesso oposto.

Temos que criar organismos que permitam a tudo o que é novo de vencer as barreiras das dificuldades iniciais e das deficiências inevitáveis. Temos inclusive que restituir ao teatro o amor que lhe é devido e que, na confusão de línguas na qual a situação atual se debate, está se perdendo.

Temos enfim de sentirmo-nos cidadãos da nossa arte, comunicando esta idéia aos outros, a fim de que percebam que uma idéia certa, muitas vezes se deturpa por defeito de qualidade ou de enunciação. 
Cidadãos de nossa arte, quer dizer da terra na qual estamos trabalhando e da qual ela deverá ser a expressão mais alta, sem o que, o teatro - como qualquer outra arte - descerá a um plano cronístico ou panfletário de constatações válidas, mas transitórias.

Acho que a presença do diretor estrangeiro continua se justificando hoje somente se ele dedicar toda a sua atenção ao autor brasileiro. A sua função é a de pôr sua experiência, sua capacidade e seus conhecimentos ao serviço de um teatro que deve ser constantemente estimulado. Temos hoje alguns excelentes autores. Eles são como algumas grandes e majestosas árvores perdidas num deserto. Devemos popular este deserto de uma vegetação e de uma seiva que permitam o processo de crescimento de uma grande floresta. As grandes árvores precisam de uma terra na qual os humores e as sementes possam circular e se reproduzir. A dramaturgia menor é indispensável em lugar de ceifar as plantas de pequeno porte para que as grandes apareçam maiores é indispensável ajudá-las a crescer.

Temos de considerarmo-nos cidadãos deste país e não turistas profissionais e fundamentalmente amar esta terra, seu povo e sua arte, como, aliás, eu a amo e nela me identifico.

\section{Gianni Ratto}




\section{BIBLIOGRAFIA}

Livros

ADLER, Stella. Técnica de representação teatral. RJ, Civilização Brasileira, 1992

APPIA, Adolphe. A obra de arte viva. Lisboa, Ed. Arcádia, s/d

ARAÚJO, Alceu Maynard. Cultura Popular Brasileira. SP, Ed.

Melhoramentos, 1977

ARISTÓTELES. Poética. Coleção Os Pensadores, SP, Ed. Abril, 1979

ARTAUD, Antonin. O teatro e seu duplo. SP, Ed. Martins Fontes, 1993

ASLAN, Odette. O ator no século XX. SP, Perspectiva, 1994

BAKHTIN, Mikhail. A cultura popular na Idade Média e no Renascimento: o contexto de François Rabelais. SP, Ed. Hucitec, 1987

BARBA, Eugenio. Além das ilhas flutuantes. SP, Hucitec, 1991 A canoa de papel. SP, Hucitec, 1994 Il corpo dilatato. Roma, La Goliardica Editrice Universitaria di Roma, 1985

BARBA, Eugenio e SAVARESE, Nicola. A arte secreta do ator. SP, Hucitec, 1995

BARRAULT, Jean-Louis. Nouvelles Réflexions sur le Théatre. Paris, Flamarion, 1959 
BARTHES, Roland. Elementos de semiologia. SP, Ed. Cultrix, 1971

BENTLEY, Eric. O teatro engajado. RJ, Zahar Editores, 1969

BERGSON, Henri. O riso. RJ, Zahar Editores, 1978

BERNHARDT, Sarah. El arte teatral. Buenos Aires, Editorial Schapire, 1946

BERTHOLD, Margot. História Mundial do Teatro, SP, Editora Perspectiva, 2000

BOAL, Augusto. Técnicas latino-americanas de teatro popular. SP, Hucitec, 1979

Teatro do oprimido e outras poéticas políticas. RJ,

Civilização brasileira, 1991

O arco-íris do desejo: o método Boal de teatro e

terapia. RJ, Civilização Brasileira, 1996

200 exercícios e jogos para o ator e o não-ator

com vontade de dizer algo através do teatro. RJ, Civilização

Brasileira, 1997

BOLELAVSKI, Richard. A arte do ator. SP, Ed. Perspectiva, 1992

BORBA FILHO, Hermilo. Teoria e prática do teatro. SP, Agência Ed. Íris, 1960

BRECHT, Bertolt. Diario de trabajo (1938-1941), Buenos Aires, Ediciones Nueva Visión, 1973

Diario de trabajo (1942-1944), Buenos Aires,

Ediciones Nueva Visión, 1973 
BRECHT, Bertolt. Diário de trabajo (1944-1955), Buenos Aires, Ediciones Nueva Visión, 1973

Teatro dialético. RJ, Civilização Brasileira,1967

BROOK, Peter. O teatro e seu espaço. Petrópolis, Ed. Vozes, 1970 O ponto de mudança. RJ, Civilização Brasileira, 1994

BURNIER, Luís Otávio. A arte do ator: da técnica à representação. Campinas, Ed. da UNICAMP, 2001

CAETANO, João. Lições Dramáticas. RJ, MEC, 1956

CANCLINI, Néstor García. A socialização da arte. SP, Cultrix, 1980

CARLSON, Marvin. Teorias do Teatro. SP, Fundação Editora da UNESP, 1997

CARVALHO, Enio. História e formação do ator. SP, Ed. Ática, 1989

CHEKHOV, Michael. Para o ator. SP, Ed. Martins Fontes, 1996

CLAIRON, Hyppolite. Mémoires D’Hyppolite Clairon, et reflexions sur la déclamation théatrale; publiés par elle-même. Paris, Chez F. Buisson, 1793

COLE Toby \& CHINOY Helen Krich. Actors on Acting.New York, Crown Publishers, 1949

COPFERMANN, Emile. O teatro popular por quê?. Porto, Portucalense Ed., 1971

CRAIG, E. Gordon. Da arte do teatro. Lisboa, Ed. Arcádia, s/d

CRUZ, Osmar Rodrigues. O teatro e sua técnica. SP, Liv. Teixeira, 1960 
CRUZ, Osmar Rodrigues e CRUZ, Eugênia Rodrigues. Osmar

Rodrigues Cruz - Uma vida no teatro. SP, Hucitec, 2001

DALCROZE, E. Jacques. Ginnastica Ritmica estetica e musicale.

Milano, Ulrico Hoepli Editore, s/d

DECROUX, Etienne. Paroles sur le mime. Paris, Éditions Gallimard, 1963

DIDEROT, Denis. Paradoxo sobre o comediante. Coleção Os

Pensadores, SP, Ed. Abril, 1979

DORT, Bernard. O teatro e sua realidade. SP, Ed Perspectiva, 1977

DUERR, Edwin. The Length and Depth of Acting. New York; Holt, Rinehart and Winston, 1962

DUVIGNAUD, Jean. Sociologia do comediante. RJ, Zahar Ed., 1972

ECO, Umberto. Tratado geral de semiótica. SP, Ed. Perspectiva, 1980

ESSLIN, Martin. Uma anatomia do drama. RJ, Zahar Ed., 1978

EWEN, Frederic. Bertolt Brecht, sua vida, sua arte, seu tempo. SP, Ed. Globo, 1991

FERNANDES, Ciane. Pina Baush e o Wuppertal dança-teatro: repetições e transformações. SP, Ed. Hucitec, 2000

FERREIRA, Procópio. O Ator Vasques. RJ, Ed. Funarte/SNT, 1979. Arte de Fazer Graça. RJ, Empreza Brasil Ed. Ltda, 1925.

FO, Dario. Manual mínimo do ator. Org. Franca Rame. SP, Ed. Senac, 1998 
GARRONE, Alessandra Galante. Alla ricerca del próprio clown.

Firenze/Milano, La Casa Usher, 1980

GHIRON-BISTAGNE, Paulette. Recherches sur les acteurs dans la

Grèce Antique. Paris, Société D’Édition “Les Belles Lettres”, 1976

GIRAUDET, A.. Mimique, Physionomie et Gestes. Paris, LibrairiesImprimeries Reunis, 1895

GLUSBERG, Jorge. A Arte da Performance. SP, Ed. Perspectiva,

GORCHAKOV, N.. Lecciones de regisseur Vajtangov. Buenos Aires, Editorial Quetzal, s/d

GROTOWSKI, Jerzy. Em busca de um teatro pobre. $4^{\text {a }}$ ed., RJ, Civilização Brasileira, 1991

GUZIK, Alberto. TBC: Crônica de Um Sonho. São Paulo, Perspectiva, 1986.

HAUSER, Arnold. História Social da Literatura e da Arte. 2 volumes, SP, Ed. Mestre Jou, s/d

HEGEL, Georg Wilhelm Friedrich. Estética. Coleção Os Pensadores, SP, Ed. Nova Cultural, 1996

HETHMON, Robert H.. El metodo del actors studio. Madrid, Ed Fundamentos, 1972

HUIZINGA, Johan. Homo Ludens. SP, Ed. Perspectiva e Ed. da USP, 1971

JANUZELLI, A.. A aprendizagem do ator. SP, Ed. Ática, 1986

KOUDELA, Ingrid Dormien. Brecht: um jogo de aprendizagem. SP, 
Perspectiva/Edusp, 1991

Um vôo brechtiano. SP, Perspectiva, 1992

KUSNET, Eugenio. Ator e Método. RJ, Serviço Nacional de Teatro, 1975

LABAN, Rudolf. Domínio do movimento. SP, Ed. Summus, 1978

LECOQ, Jacques. Le théâtre du geste: mimes et acteurs. Paris, Ed. Bordas, 1987

LEWIS, Robert. Método ou loucura. RJ, Ed. Letras e Artes, 1962

LICIA, Nydia. Ninguém se livra de seus fantasmas. São Paulo: Perspectiva, 2002.

MAGALDI, Sábato. VARGAS Maria Tereza. Cem anos de teatro em São Paulo. São Paulo: Editora SENAC São Paulo, 200.

MAGALDI, Sábato. Teatro Sempre. São Paulo: Perspectiva, 2006.

O Texto no Teatro. São Paulo: Perspectiva, 2001. $3^{\text {a }}$ edição.

Depois do Espetáculo. São Paulo: Perspectiva, 2003.

MEICHES, Mauro e FERNANDES, Sílvia. Sobre o Trabalho do Ator. São Paulo: Perspectiva, 1999.

MEYERHOLD, V. Teoria teatral. Madrid, Ed. Fundamentos, 1979

MENDONÇA, Carlos Sussekind de. História do Teatro Brasileiro. RJ,

Mendonça Machado e Cia., 1926

MORBIO, Vittoria Crespi. GIANNI RATTO alla Scala. Milano, Umberto Allemandi \& C., 2004. 
NICOLL, Allardyce. Historia del teatro mundial. Madrid, Aguilar S. A. de Ediciones, 1964

NIETZSCHE, Friedrich. O nascimento da tragédia no espírito da música. Coleção Os Pensadores, SP, Ed. Abril, 1983

OIDA, Yoshi. Um ator errante. SP, Beca Prod. Cult., 1999 O ator invisível. SP, Beca Produções Culturais, 2001

PAVIS, Patrice. Dicionário de Teatro. São Paulo, Ed. Perspectiva, 1999.

PEIXOTO, Fernando. Uma introdução ao teatro dialético. RJ, Paz e Terra, 1981

Brecht vida e obra. RJ, José Álvaro Editor, 1968

PERRUCCI, Andréa. Dell'arte rappresentativa premeditata ed all’improvviso. Firenze, Edizione Sansoni Antiquariato, 1961

PISCATOR, Erwin. Teatro Político. RJ, Civilização Brasileira, 1968

PLATÃO. República. Lisboa, Publicações Europa-América, 1975

PLEKANOV, J. e outros. Sociologia da arte. SP, Cultura, 1945

POTTECHER, Maurice. Le théâtre du peuple. Paris, Libraire Paul Ollendorff, 1899

PRADO, Décio de Almeida. João Caetano. SP, Ed. Perspectiva,1972 João Caetano e a Arte do Ator. SP, Ed. Ática, 1984 Procópio Ferreira. SP, Ed. Brasiliense, 1984 
Apresentação do TEATRO BRASILEIRO MODERNO. São

Paulo: Perspectiva, 2001.

O Teatro Brasileiro Moderno. São Paulo: Perspectiva, 2003.

Teatro em Progresso.São Paulo: Perspectiva, 2002.

PROPP, Vladimir. Comicidade e riso. SP, Ed. Ática, 1992

PUAUX, Melly e Paul; MOSSÉ, Claude. L'aventure du théâtre populaire. Monaco, Éditions du Rocher, 1996

RANGEL, Otávio. Escola teatral de ensaiadores. RJ, Ed.

Talmagráfica, 1954

RATTO, Gianni, Hipocritando - Fragmentos e Páginas Soltas. RJ, Bem-Te-Vi Produções Literárias, 2004.

RATTO, Gianni, Antitratado de Cenografia - Variações sobre o mesmo tema. São Paulo, Editora SENAC São Paulo, 1999.

RATTO, Gianni. A Mochila do Mascate. São Paulo, Editora Hucitec, 1996.

RAULINO, Berenice. Ruggero Jacobbi. São Paulo: Perspectiva, 2002.

REDGRAVE, Michael. Los medios expressivos del actor. Buenos Aires, Ediciones Leviatan, 1956

REDONDO JR.. O teatro e sua estética. Lisboa, Ed. Arcádia, s/d

RICCOBONI, Luigi. Discorso della commedia all'improviso e scenari inediti. Milano, Edizioni Il Polifilo, 1973

Dell'arte rappresentativa. Ristampa dell'edizione 
di Londra 1728, Arnaldo Forni Editore, 1979

RICE, Elmer. Teatro vivo. RJ, Ed. Fundo de Cultura, 1959

RIPELLINO, Ângelo Maria. O truque e a alma. SP, Perspectiva, 1996

ROCHA FILHO, Rubem. A personagem dramática. RJ, INACEN, 1986

ROLLAND, Romain. EI teatro del pueblo. Buenos Aires, Editorial Quetzal, 1953

ROSENFELD, Anatol. O teatro épico. SP, Perspectiva, 1985

ROUBINE, Jean-Jacques. A linguagem da encenação teatral. RJ, Ed. Zahar, 1982 A arte do ator. RJ, Zahar Ed., 1985

SCHERER, Jacques; BORIE,Monique e ROUGEMONT, Martine de. Esthétique Théâtrale. Paris, Editions C.D.U. et Sedes reunis, 1982

SCHILLER, Friedrich. Teoria da tragédia. SP, Ed. Herder, 1964 Sobre a Educação Estética. SP, Ed. Herder,1963

SILVA, Armando Sérgio da. Uma Oficina de Atores. SP, EDUSP,1987

SILVEIRA, Miroel. A Outra Crítica. São Paulo, Editora Símbolo, 1976.

SPOLIN, Viola. Improvisação para o teatro. SP, Perspectiva, 1963

STANISLAVSKI, Constantin. A preparação do ator. RJ, Civilização Brasileira, 1976

A construção da personagem, $\mathrm{RJ}$,

Civilização Brasileira, 1970

A criação de um papel. RJ, Civilização 
Brasileira, 1972

STRASBERG, Lee. Um sonho de paixão. RJ, Ed. Civilização Brasileira, 1990

TALMA, F.. Mémoires de Lekain. Paris, Chez Ponthieu Libraire au Palais-Royal, 1825

TOUCHARD, Pierre-Aimé. Dioniso - Apologia do teatro, $O$ amador de teatro ou a regra do jogo. SP, Cultrix,1978

VANUCCI, Alessandra. Crítica da Razão Teatral - O Teatro No Brasil Visto Por Ruggero Jacobbi. São Paulo: Perspectiva, 2005.

VIANNA, Klauss. A dança. SP, Ed. Siciliano, s/d 


\section{Periódicos}

Ratto, Gianni. Entrevista. Revista ATERCEIRAIDADE, SESC - volume 14, nº26 Janeiro, 2003

Vallecchi Editore. Quaderni di teatro - Il teatro e la scuola, Firenze, 1987

Stampa Vallardi \& Associati. Teatro d'Europa - Rivista/Programma

Del Piccolo teatro di Milano. Milano, 1988

Cruz, Osmar R.. A arte de dizer. Revista do teatro amador. Caderno de Teatro $\mathrm{n}^{\mathrm{o}} 1$, SP, Ano I, números 1 a 7, 1955

Noções da arte de representar. Revista do teatro amador. Caderno de

Teatro nº 3, SP, Ano I, números 1 a 7, 1955

Cruz, Osmar R.. Origem da renovação do teatro brasileiro. Revista de Estudos

Teatrais. № 1 , Ano I, números 1 a 5 (abril, junho, setembro, dezembro de 1958)

Vaghtangov, E.. Preparando a personagem.

Revista de Estudos Teatrais. $\mathrm{N}^{\mathrm{o}}$ 2, Ano I, números 1 a 5 (abril, junho, setembro, dezembro de 1958)

Dyonisos - Ano XII - no 15 - Dezembro de 1967. Rio de Janeiro.

Revista Teatro Brasileiro no 3 - Janeiro de 1956. São Paulo.

Revista de Estudos Teatrais $\mathbf{n}^{\mathbf{0}} 2$ - Junho de 1958. São Paulo.

Revista Camarim - Ano II - no 8 - Maio de 199. São Paulo.

Folhetim - Teatro do Pequeno Gesto - número 21- jan-jun 2005. Rio de Janeiro.

Revista Cidade - Revista do Museu da Cidade de São Paulo - Ano 1 - mar. 1994. São Paulo.

O Percevejo - Ano II, no 2 - 1994. Rio de Janeiro.

O Percevejo - Ano 3, no 3 - 1995. Rio de Janeiro.

O Percevejo - Ano 4, no 4 - 1996. Rio de Janeiro.

O Percevejo - Ano 5, no 5 - 1997. Rio de Janeiro.

O Percevejo - Ano 6, nº - 1998. Rio de Janeiro.

O Percevejo - Ano 7, $\mathbf{n}^{\mathbf{0}} 7$ - 1999. Rio de Janeiro.

O Percevejo - Anos 9/10, $\mathbf{n}^{\mathbf{0}} \mathbf{s}$ 10/11 - 2001/2002. Rio de Janeiro 
Brasil - Almanaque de Cultura Popular - ano 6 - no 72 - Março - 2005. TAM.

Sipario - Dicembre n. 666 - 2004. Milano. Itália

Sipario - Luglio/Agosto - 2005. Milano. Itália. 
Dissertações e Teses:

GARCIA, Clovis. O teatro profano medieval francês como expressão da sociedade burguesa, no século XIII. Tese Doutorado, ECA/USP, SP, 1972

LOPES, Elisabeth Silva. O ATOR BUFÃO. Tese Doutorado, ECA/USP SP, 2001

PINTO, Karen Astrid Müller. A Poética do Corpo em Movimento: do conhecimento à expressão. Tese de Doutorado, Universidade de São Paulo,2002

SANTOS, Maria Thaís Lima. Meyerhold: O Encenador Pedagogo. Tese de Doutorado, Universidade de São Paulo, 2002.

SARAIVA, Hamilton Figueiredo. Iluminação Teatral: História, Estética e Técnica. Dissertação de Mestrado, ECA/USP, 1989

Interações Físicas e Psíquicas Geradas pelas

Cores na Iluminação Teatral. Tese de Doutorado, ECA/USP, 1999 
Anexos 


\section{Entrevista Sérgio Britto}

Gostaria que você falasse um pouco sobre seu trabalho com o Gianni Ratto, a direção dele, seu trabalho no Teatro dos Sete, e também sobre a direção do Mambembe.

O Gianni Ratto quando veio da Itália, veio um homem pronto do Strehler, Giorgio Strehler. O Strehler era um dos homens mais rigorosos, mais difíceis do planeta. Era difícil, era exigente, era mandão, absoluto. Muita gente deixou de trabalhar com ele, pelo excesso de rigor dele. Agora, foi um diretor extraordinário que fez algumas das melhores coisas que na Itália, jamais se fez. O que é uma coisa curiosa, a Itália se pensa como um país de um grande teatro. Tudo tem Itália, teatro, teatro, teatro, mas não é. Estive duas vezes na Itália e raramente vi um espetáculo cem por cento. Eles são muito intelectuais, eles ficam numa masturbação estilística tão grande, tão grande, tão grande que o resultado final não é nada, é uma coisa pobre. Não o Strehler. Quando o Ratto largou o Strehler e aceitou o convite, um convite misterioso, de uma moça chamada Maria Della Costa foi porque queria sair daquilo. Porque na cabeça dele já estava a idéia de que ele queria dirigir. Quando o Ratto chegou aqui no Brasil a primeira coisa que aconteceu ele inventou um verbo, como bom italiano que era ele não encontrava a palavra e inventou um verbo "repeguemo", repeguemo. "Repeguemo essa cena". Agora, ao mesmo tempo ele foi pra nós uma grande surpresa. Nós estávamos acostumados a ensaiar como? Lia a peça e no dia seguinte já estávamos marcando, movimentando. Com ele era dois meses na mesa lendo detalhadamente tudo. Explicando o autor, a filosofia do autor, o pensamento político e social do país, a moda, e como as pessoas usavam aquelas roupas daquela época. Olha que loucura. Quando se levantava da mesa, depois de dois meses depois do ensaio, já estava pronta a peça. Você já tinha incorporado tudo. Tava prontinho pra fazer a peça. Agora, nunca isso foi, no início um embaraço para nós com o Ratto. "O Canto da Cotovia", fizemos A Moratória que foi uma grande descoberta dele estar dirigindo o Jorge Andrade, foi A Pulga Atrás da Orelha. Mas um dia o rigor dele entrou em atrito com o Sandro Polônio. Sandro disse: vamos viajar, e vamos cortar alguns papéis secundários para tornar economicamente viável essa viagem. Sandro chegou à noite no teatro, depois do espetáculo : "Eu quero uma reunião do elenco". Gianni disse: Como estou dando prejuízo ao Sr. Sandro Polônio eu vou pedir demissão. Nós estávamos preparando uma nova peça. Nós vamos ensaiar, estrear a peça que estamos preparando e depois disso eu não sou mais da Companhia de Maria Della Costa. Fernanda, Fernando, Milton Moraes, Ítalo Rossi, nós tínhamos nos colocado (sic) fiéis seguidores daquele homem chamado Gianni Ratto, Wanda Kosmos, Fregolente, Lígia de Abulquerque. E ele disse que em vista disso a gente não queria ir para o $\mathrm{TBC}$, foi o que aconteceu.

Essa montagem que aconteceu isso foi qual?

"Buonna Ventura alla isola dei papagalli".

Ah, a Ilha dos Papagaios!

Isso. A Ilha dos Papagaios. Buona Ventura era o nome do personagem. Do Sergio Toffano, era um ator muito bom do cinema, fazia desenhos, publicava no jornal e ele mesmo fazia o papel. E eu fiz esse papel, tive o prazer de fazer esse papel. Vinte dias só 
de espetáculo. Ah, Dá uma dor no coração! A Ilha dos Papagaios era um homem que morava na ilha dos papagaios e tinha uma aventura, uma história infantil. Ele era fotógrafo. Tinha coisas assim, por exemplo, eu tirando fotografia e o Sabbag fazia o cachorro que atrapalhava a fotografia. Eu colocava a câmera num lugar e o Sabbag vinha e "pum" dava um tropeção na câmera que caía, desmanchava a luz, desmanchava tudo, e tinha que recomeçar tudo de novo. Eu punha todo mundo sentado e olhava e dizia, mudou a luz, muda tudo! Era muito bom.

\section{E “A Pulga Atrás da Orelha”}

Foi feita duas vezes, uma no Maria Della Costa, um espetáculo mais ou menos porque a experiência do elenco ainda era pequena. O Ratto não chegou a fazer no grupo Maria Della Costa o resultado mais absoluto dele como diretor. Daí ele foi para o TBC. Lá ele fez Eurydice do Anouilh, Nossa Vida com Papai, e aí eu tomei parte. Ele começou ensaiar, nessa época havia política no TBC, começou a ensaiar o Crime e Castigo de Dostoievsky, e daí nós recebemos a seguinte notícia: "Não tem Crime e Castigo". Porque Dona Cacilda Becker, a dona do TBC, por que era uma figura apaixonante. Eu tinha loucura pela Cacilda. Nunca, depois de uma estréia, eu não fiquei pelo menos meia hora conversando com ela sobre o que eu tinha visto. Eu adorava a Cacilda, e sei que ela gostava de mim também, mas desta vez ela fez o seguinte: - Essa turma tá entrando e já vai fazer Crime e Castigo, que história é essa? Não eles não vão fazer Crime e Castigo não! Tirou o Crime e Castigo da nossa mão. Ela era a estrela do TBC e nessa altura ela mandava absolutamente, porque além de ser a estrela do TBC, essa altura ela mandava absolutamente porque além d eser a principal figura do TBC, a figura que marcava o TBC era adorada pelo Zampari, e era caso do Celi. A vida foi muito ingrata com ela, não é? porque foi largada pelo Celi, depois foi largada pelo Walmor. Sozinha na vida. Quando a Cacilda morreu, com enfarte, estava sozinha. Na véspera da morte dela eu fui pra assistir Esperando Godot. Porque ela estava muito triste. Sei que ela estava conversando comigo e pelo espelho, chegou Walmor apareceu na porta, Walmor tinha se desligado dela outra vez, tinha caído na gandaia, ele disse Cacilda eu te telefono ao meio-dia. - Pois não Walmor, tchau! Ele saiu, ela ficou olhando pra ele, os olhos baixados, bateram nos meus, direto!! Aí fez assim (faz um gesto de desamparo), que que eu posso fazer? Olhe, estabeleceu-se um clima de tristeza tão grande que eu não pude falar mais nada. Só sei que fui embora, me despedi dela, dei um beijo nela, e ela morreu na semana seguinte.E há uma imagem que a Marília Pêra conta, que é emocionante. A Marília Pêra estava na porta do teatro, viu uma ambulância parada lá, quando olhou disseram que houve um acidente com a atriz. Marília entrou no teatro. Cacilda estava sendo carregada pra fora do teatro. Os caras seguraram o corpo dela mas deixara um dos braços dela de fora, e o braço foi batendo em todas as cadeiras do teatro.

\section{Aí ela deixou fazer o Dostoiewsky?}

Nós fizemos com o Walmor, aí veio Vaneau, veio o Luciano Salce, o Ruggiero Jacobi, o Bollini, e depois o Alberto D'Aversa. Enfim nós acabamos trabalhando com o Gianni Ratto muito pouco. Um dia ele foi despedido pelo Zampari. Quando ele despediu nós ficamos lá parados, porque nós tínhamos largado a Maria Della Costa, tínhamos largado tudo pra segui-lo. Aí ele foi embora para a Itália, e depois foi dar aulas na Bahia. Nós ficamos trabalhando no TBC ainda alguns meses, nós trabalhamos até 56, 56, 57, 58 e no fim de 58 nós viemos pro Rio. Nós estávamos planejando fazer uma companhia. Daí 
nós fizemos uma campanha de assinaturas pra ter dinheiro pra poder começar o grupo. Conseguimos em um mês, alguma coisa, naquela época um milhão de reais, de cruzeiros, não sei o que era, em cinqüenta e nove era cruzeiro. Daí nós iríamos estrear na mesma época em que era aniversário do Theatro Municipal. O Municipal deu o cenário e os figurinos de presente, nós merecíamos e ganhamos isso. O Hugo Napoleão fez os figurinos e o Ratto fez os cenários. Bom, O Mambembe tinha 84 (sic) pessoas em cena. Uma loucura! A história do Mambembe foi uma das coisas mais inacreditáveis que eu já assisti. Não houve nada, eu nunca vi um espetáculo, nem estrangeiro, nem brasileiro, nem tomei parte, nem vi de fora alguma coisa que tivesse a reação da platéia. Porque a platéia urrava, gritava encantada nomeio. A beleza que era o espetáculo, que era a cenografia do Ratto, toda pintada, toda pintada, pintada por ele.

Bom, enquanto estivemos na Maria Della Costa fizemos O Canto da Cotovia, A Moratória, fizemos o Canto da Cotovia no Rio, voltamos, fizemos Mirandolina com direção do Ruggero Jacobi, que foi mais ou menos, fizemos... Buonna Ventura já falei, mas fizemos mais alguma coisa... O grande problema foi que a companhia não se sustentava porque nós viajávamos com esse repertório, e era um deslumbramento, no Brasil inteiro! Com a Maria Della Costa. Mas o Gianni um dia resolveu..., aí deu nele um "Strehler". Ah, nós montamos um espetáculo, que de memória foi de memória, muito importante: Cristo Proclamado. Que é a grande discussão do Gianni no documentário (A Mochila do Mascate) a nosso respeito. Que ele diz que nós não queríamos montar Cristo Proclamado, que nós, elenco. E que nós prejudicamos à vontade, de propósito (sic). Ele chega e começa a fazer Cristo Proclamado. Nós tomamos um susto. A peça era dificílima, e era muito estranha pra época. Numa cidade do interior vai se fazer a representação da Semana Santa, e quem faz o papel do Cristo é eleito prefeito da cidade. Então eu vinha de fora, recém formado em advocacia, fillho do papai rico, pra ganhar o papel do Cristo, e ganhar a eleição. Chego lá, ninguém simpatiza comigo e o papel do Cristo fica com o médico. Então na hora da representação toda aquela turma do interior, imagina só uma rampa, só tinha uma rampa, uma rampa assim e uma árvore. Só isso em cena. Olha como ele era avançado. Aquela gente toda se vestia de romeiro e saia pela rua fazendo a história de Cristo. To lá em cima da montanha junto com meus asseclas e Cristo ta passando lá embaixo. Qual é o golpe dele? Ele mata o Cristo. Dá um tiro de revólver e mata o Cristo, e mata dois que estavam ao lado dele dizendo que eles é quem mataram o Cristo. Ele vira herói e é eleito prefeito. Assim termina a peça. Uma peça muito difícil, muito seca. Era uma hora de espetáculo. Um fracasso, monumental, fora de qualquer medida.

Nós estreávamos uma peça naquela época. Estreávamos na quarta, no sábado já estava lotado e já estava lotado para o outro sábado. Em Cristo Proclamado, no primeiro sábado nós tivemos cinqüenta pessoas, no outro nós tivemos quarenta. Ficou em cartaz durante três semanas.

Foi o público que não entendeu a peça?

Não, não foi o público que não entendeu a peça. Eu acho que é mais do que isso. Não entendeu a peça não. A peça, para aquela época, era muito avançada. Era avançada demais. As pessoas não entendiam aquela linguagem, aquela frieza. Imagina só o seguinte, todos os retirantes, tudo com aquele pano na cabeça, amarrado, pé descalço. Me lembro da Zilka (Zilka Salaberri) na frente com uma trouxa debaixo do braço, e eu com um microfone, de costas pra platéia, fazendo um discurso prometendo que nunca mais ia deixar de chover. Eles acreditavam e votavam em mim. Você imagina!! 
Um dia, eu e Fernanda começamos a rir no teatro, num canto, quando chegamos em casa telefonamos um para o outro, às gargalhadas, dizendo que fracasso que ia ser. Sentimos que fracasso ia ser.

E vocês chegaram a falar isso pra ele? O que vocês sentiam?

Falamos do medo que tínhamos da peça. Mas ele insistiu, pois ele era o dono da bola.

E mesmo nessa peça vocês mantinham o mesmo processo sempre? Digo, de dois meses de leitura, isso era uma coisa normal.

Sempre, sempre houve isso. Ele foi pra terra do Francisco Pereira..., como era o nome dele mesmo meu Deus, o nome do autor. Bem, o Francisco achava lindo tudo aquilo. A peça saiu de cartaz e a crítica, os jornais foram contra nós: Eles tinham a obrigação de manter a peça, não sei o quê... Mas a verdade é que quem ia pagar o elenco. Eram trinta pessoas no elenco. Tivemos que tirar. E ele concordou em tirar. Nós, pra podermos sustentar e não despedir um elenco de trinta pessoas, porque nós sempre tivemos uma preocupação, digamos social, nós remontamos $\mathbf{O}$ Mambembe e saímos viajando com $\mathbf{O}$ Mambembe pra Niterói. Chegava às seis horas da tarde tomávamos uma barca para Niterói, apresentávamos O Mambembe e voltávamos pra ensaiar o Grande Teatro (Grande Teatro Tupi), e ao meio-dia, no dia seguinte, ensaiávamos Com a Pulga Atrás da Orelha, que nos salvou. Que foi um ano de sucesso. Depois da Pulga veio o Beijo no Asfalto, que o fi-lo porque quilo (Jânio Quadros) destruiu. Que era um sucesso devastador. O Beijo no Asfalto foi um escândalo. Foi uma coisa fora do comum. Eu acho que uma das melhores peças do Nelson. Até Dona Bárbara (Bárbara Heliodora) acha bom. A Bárbara acha a melhor peça dele. Não sei se é a melhor peça dele, mas é uma peça ótima. Depois nós fizemos...Fomos pra Maison de France, porque aí a desordem social e econômica que gerou a saída do Gianni fez tudo cair. Nós fomos pra Maison de France porque era mais barato. Aí fizemos um dos melhores espetáculos de nossas vidas, Festival de Comédia, era Martins Pena, aliás na ordem era..Cervantes, Molière, Martins Pena. Um espetáculo inacreditável. O Cervantes era uma tábua com uma inclinação, com uma cortina. Eles na rua. Depois o Molière já era feito num palco, com um cenário todo elaborado, tinha uma casa de dois andares. $\mathrm{O}$ Ítalo (Ítalo Rossi) subia com um personagem e descia como outro, só mudando uma coisa, era uma coisa impressionante. E no final nós fazíamos do Martins Pena, Os Ciúmes de um Pedestre. Que também era um delírio danado. Naquela época nós éramos os atletas do teatro. Pra você ter uma pequena idéia, se o Ítalo subia o cenário e descia como outro personagem. No Martins Pena eu tinha um ataque de fúria, pulava do palco na platéia corria até o fundo do teatro, voltava correndo, subia no palco outra vez. Eu nem sei como eu fazia uma coisa dessas. E fazia! Agora já não foi muito bem, mas se sustentou porque o Maison de France era barato. Agora, o processo era o seguinte, o Gianni recebia o ordenado dele e nós não. Seis anos nós trabalhávamos na televisão e vivíamos do Grande Teatro, da televisão. No fim do ano o que sobrava do dinheiro Fernando (Fernando Torres) chamava a gente e dividia entre nós. Era assim. Fernando era o produtor, era um herói, porque agüentar essa parada... Ele adorava o Ratto, não admitia que dissesse uma palavra contra o Ratto. Era adoração, adoração, adoração absoluta. Aí nós fizemos O Homem, a Besta, e a Virtude, do Pirandello, foi um sucesso mediano. Mas nós precisávamos de um sucesso. Aí viajamos outra vez, refizemos O Beijo (O Beijo no Asfalto), fizemos várias tentativas. Fizemos uma loucura com música de Luciano Berio. Sabe que foi Luciano Berio? Um músico 
concretista. Nós fizemos uma coisa chamada Apague o Spotlight Por Favor do Joyce de Oliveira. Que era uma coisa louquíssima, nós fazíamos vários personagens, personagens históricos. Era uma mulher numa mesa de um analista, num divã, e ela sonhando com as coisas dela. Eu fazia um Dom Quixote, eu fazia não sei quem, o Ítalo fazia...olha, era uma doideira o espetáculo. Agora tudo isso com uma música do Luciano Berio que consistia no seguinte, os nossos sons transformados em música. Nós tamos conversando, pega essa conversa e transforma em música e vira la, la, la, la, la (ele canta). Nós fizemos três vezes esse espetáculo no Municipal de São Paulo e duas vezes no Municipal do Rio. Apague o Spotlight Por Favor, de Joiyce de Oliveira. Aliás precisava conversar com ela. Uma mulher completamente maluca, tarada. Aí fizemos A Mirandolina, esse foi o nosso desastre. Foi o rompimento definitivo. Porque pensa Mirandolina do Goldoni, uma comédia hilariante, uma comédia maravilhosa, safada, sensual. O Gianni resolveu fazer um espetáculo italiano, no modelo exato, não permitiu uma graça, não permitiu um gesto a mais. Fernanda (Fernanda Montenegro) fazia a Mirandolina, ela era a dona da locanda, La Locandiera, a mão era nas pernas (ele mostra), não podia fazer assim (mostra novamente) daí ele dizia: Não, essa gesticulação é brasileira, não, não, não. Controlou a gente totalmente. Aí nós fomos dirigidos de maneira absoluta, e eu não posso discutir a qualidade da direção. Eu nunca viu um Goldoni, a não ser pelo Piccolo (Piccolo Teatro di Milano), o Arlecchino que era um espetáculo maravilhoso. Mas ele fez o seu Arlecchino (Arlecchino, Servidor de Dois Amos), porque o Arlecchino na Itália é um espetáculo que marcou época, a vida do Piccolo a vida do Strehler (Giorgio Strehler), a vida do teatro italiano. Nós dissemos, Gianni isso não vai dar certo, aí nós começamos a dizer. Mas ele, "É assim que eu quero". Não teve público, foi um fracasso. Nós perdemos tudo que tínhamos posto. Aí ficamos com dívidas em três bancos. Sentamos e dissemos Gianni nós podemos pagar essas dívidas daqui a três meses, mas temos que pagar, nós vivemos da televisão. Aí ele disse é vamos montar Durrenmatt. Mas Gianni é um outro autor complicado, nós temos no momento que ceder, vamos fazer uma coisa mais simples, vamos fazer uma comédia, vamos fazer um Feydeau que nós fizemos tão bem Com a Pulga. Um dia ele telefonou pra nós e disse, Quanto é a dívida? - É tanto. - Eu vou mandar um cheque com a minha quantia. Ele acabou com o Teatro dos Sete, ele mandou o cheque que correspondia ao que ele devia. Ele era uma pessoa... olha, eu não posso explicar o Gianni, era um talento monstruoso, um homem com idéias absolutamente corretas, certas, seguras, definitivas sobre o que ele queria fazer em teatro. Mas era uma pessoa quase que impossível. Aí nós pegamos Henri Becque, o primeiro autor naturalista. Henri Becque, francês. Pedimos ao Millôr (Millôr Ferandes) que fizesse uma adaptação, o Millôr fez uma adaptação para o Brasil. Chamava-se “A Mulher de Todos Nós”.Falamos com o Gianni. Gianni, uma boa comédia, porque não é uma comedinha, é uma comédia com substância. - Não, eu já paguei a minha parte. Não quis. Nós fizemos A Mulher de Todos Nós, foi um sucesso inacreditável, no Teatro Santa Rosa, que já não existe mais, fizemos O Homem do Princípio ao Fim do Millôr Fernandes, e fizemos a "Volta ao Lar", do Pinter. Com essas três peças nós vivemos três anos, até 1970 quando nós fomos pra São Paulo, nos estabelecemos no Teatro Maria Della Costa, onde nós fomos fazer as três peças, e eu fui pra televisão dirigir a Bibi Ferreira, Bibi ao Vivo. Aí um dia me disseram assim: Ah não, você devia dirigir é novela, e a Fernanda e o Fernando estavam vacilando, eu senti o vacilo. Eles queriam ficar viajando pelo Brasil afora, eu não queria. Ficar fazendo aquelas peças toda vida, ah não. Aí no desligamos e acabou o Teatro dos Quatro. Foi assim que acabou. A nossa amizade, da nossa geração, nunca acabou, tanto assim que a primeira coisa que eu fiz quando saí de São Paulo, quando a TV Excelsior fracassou, faliu mesmo, eu fiz a Ruth Escobar, Os Autos Sacramentais 
em 1974, eu dirigi uma ópera no Rio de Janeiro, A Traviata, fiz A Gaivota, direção do Lavelle, também no Theatro Municipal. Foi um ano muito estranho. Lavelle veio de Paris dirigir "A Gaivota" do Tchekov, eu dirigi A Traviata, e saí pra viajar com o Vitor Garcia, nu, fazendo, todo mundo nu fazendo os Autos Sacramentales, então...

Qual foi a importância do Gianni na sua carreira?

Eu acho que o Gianni foi o homem que me ensinou o amor ao teatro, o respeito ao teatro, aquele que nunca escolhia entre a versão dele e a versão que ele achava a mais correta. A versão mais correta é a que devia ser feita. A versão que mais dava ao autor a sua verdade mais absoluta, essa é que devia ser feita. Ele era chamado por muita gente de quadrado por isso, mas isso não é verdade, isso é uma coisa injusta. O Gianni era um corretíssimo diretor de espetáculo e de atores. Ele fez espetáculos inesquecíveis, não preciso falar no Mambembe, sem falar em Eurídice, Nossa Vida com Papai, ele fez Bona ventura, fez Moratória, ele descobriu Jorge de Andrade. É um espetáculo que todo mundo tem feito, nunca ninguém se aproximou nem ligeiramente da pureza e da simplicidade de Gianni. Era um cenário dividido em dois, que era o presente e o passado. A mesma família morando numa casa e morando na outra casa depois da decadência. Alguns dos objetos eram mantidos, isso era um detalhe de uma beleza poética, por exemplo esse relógio que eu tenho aqui, vou pra outra casa pego esse relógio e ponho na parede. O relógio, o retrato da santinha, a mesma mesa e a máquina de costura. Era uma coisa impressionante.

Uma coisa que ele falava da Moratória, era sobre a generosidade da Maria Della Costa, porque ele achava que não tinha papel para ela e era a Fernanda, que estava entrando, quem deveria fazer o papel feminino.

Ah, a Maria foi uma pessoa muito especial, foi uma pessoa muito especial. Na época em que saímos do Maria Della Costa para irmos pro TBC, foi muito doloroso, foi muito machucado da gente dizer não a Maria e ir pro TBC, foi, foi muito duro, duro mesmo. Agora uma coisa muito importante pra dizer a você mais, é o seguinte, que o Gianni Ratto é, na minha opinião, na da Fernanda também e na do Fernando também a figura que determinou o nosso jeito de ser pro teatro. Nós somos assim porque o Gianni Ratto existiu. Nós somos assim porque o Gianni Ratto nos ensinou a ser assim.

Eu queria que você confirmasse esse trabalho de mesa do Gianni e sua preocupação com o trabalho do ator...

Reproduzindo o estilo e realmente o autor como ele era. Gianni fez espetáculos extraordinários, todos inventados em cima do autor. Já eram os italianos fazendo o que hoje todo mundo faz, pega um autor e diz com o autor aquilo que quer dizer, não que o autor quis dizer,( que eram o que realmente eles faziam).

Ele tinha essa preocupação de que o ator também conhecesse também toda a história, como você falou a história da época, o figurino da época...

Profundo, profundo..você sabia o que estava fazendo, sabia o que queria dizer. 
E que hoje em dia não existe mais..

Eu acho que o Gianni, isso é a conclusão do meu depoimento sobre o Gianni, é que ele foi o nosso mestre, ele foi aquela pessoa que nos ensinou o que é o verdadeiro teatro. Eu trabalhei com pessoas como o Geraldo Thomas, com o... Victor Garcia, trabalhei com o Georges Davelle, trabalhei com a Nely Frank, trabalhei com pessoas muito interessantes, sabe, mas e daí? Nenhum deles se aproxima sequer dele, porque. É uma outra mentalidade. O Gerald Thomas inventa um espetáculo maravilhoso e depois faz um espetáculo detestável. E esse é o processo dele. O Gianni procurava seguir absolutamente o autor, mas as vezes a fidelidade total ao autor gera o fracasso, para o grande público. Eu nunca mais me esqueço que o Millôr Fernandes sempre quis traduzir Shakespeare e dizia se você quiser ser autêntico vai fazer um fracasso, você tem que traduzir o espírito do Shakespeare. É impossível traduzir o Shakespeare. É uma outra língua, uma outra época, um outro estilo, então você tem que traduzir o espírito.

Sobre o Mambembe. O que levou a fazer o Mambembe? Porque foi um grande sucesso! De onde veio essa idéia.

Foi o Ratto que nos convenceu a fazer o Mambembe. Era a idéia de um espetáculo musical que nunca se tinha feito no Brasil. Eram oitenta e quatro pessoas em cena, cantando, dançando e representando. Nós éramos tantos que quando nós saímos do Municipal, onde ficamos quinze dias, fomos pro Copacabana nos reduzimos a sessenta, porque não cabiam dentro dos camarins os oitenta e quatro.

E ele também pintou o cenário todo do Mambembe?

Todo. Não, foi uma direção, olha, memorável. Quando o Mambembe acabou, pra você ter uma idéia mais ou menos o Mambembe começou às nove horas, acabou quinze pra meia-noite. Duas hora e quarenta e cinco minutos, porque ele também não cortava peça. Nós ficamos no teatro até as três horas da manhã, porque quando acabou o espetáculo nós não tínhamos chegado aos nossos camarins e o público já estava no palco, praticamente metade da platéia desceu pro palco. Agora metade da platéia do Municipal são mil pessoas. Todo mundo querendo saber, todo mundo querendo aprender as músicas, ver o cenário, ver os detalhes. Era uma coisa quase que absurda.

Seria mais ou menos dentro disso, a coisa do Mambembe aqui pro Brasil, pelo que você está me contando, o que foi o Arlequim (Arlequim, Servidor de Dois Amos), do Strehler na Itália.

É. Eu acho que O Mambembe é a marca do Gianni Ratto no Brasil. A verdadeira história dele, mais do que os sucessos que ele fez com Maria Della Costa. Com o Canto da Cotovia ele ganhou todos os prêmios, mas é o Mambembe. Talvez, se quiser competir com o mambembe é o Festival de Comédias.

Porque deveria ser uma coisa muito difícil..

Porque ele fez os três estilos. Ele fez a comédia sofisticada do Cervantes, popularesca, grossa, mas sofisticada de certo modo. Fez um Molière requintadíssimo. Eu e o Ítalo (Ítalo Rossi) tínhamos uma cena em que nós nos cumprimentávamos sessenta vezes 
antes de começar a falar. Sabe o que é fazer sessenta vezes o movimento de capa, assim pra baixo..(faz) Quando eu saía daquela coisa eu caía sentado na cadeira, aí tinha que preparar correndo pra fazer o Martins Pena (Ciúmes de um Pedestre) onde eu era o protagonista, tinha que tirar toda a maquiagem e botar barba, bigode, tudo. Uma vez cheguei perto do Gianni e disse: - Gianni, você não acha que podia dar o papel do advogado pra uma outra pessoa? Olha ele, bem Gianni Ratto: - Não, se vocês quiserem a gente monta outra peça, noutra peça vocês não fazem isso. Eu estou dando a vocês a chance de vocês provarem que são capazes de fazer três estilos diferentes. Agora se vocês não quiserem....

E era tudo numa sessão só, os três....

Numa sessão só.

O do Molière era o que?

O Médico Volante.

Ciúmes de Um Pedestre do Martins Pena e....

Ai meu Deus.....O Velho Ciumento.

E existia uma ligação entre uma peça e outra?

Não. Era um intervalo, pequeno, mas era um intervalo. Como se fosse um ato. Mas meu filho...

Era um loucura.

Uma loucura...sessenta vezes, com aquela capa preta pesadíssima. Eu tinha o que? Era 1962, eu tinha 39 anos. Eu tinha forma. Eu tenho energia até hoje, se é que ando meio desfalcado. O Ítalo era o perseguido pelo Gianni. Porque o Ítalo sempre foi um ator de talento incomensurável, mas sempre fugindo de um esforço maior. Isso é uma tendência, cada um de nós tem uma característica. A Fernanda é aquela que ...eu nunca esqueço a leitura da Fernanda é assim: ela mete a cabeça na peça e some! Aqui ta a peça, ela some!! Em um mês você não vê a cabeça da Fernanda, aí de repente aparece a cabeça, ela afasta assim...Já ta pronto o papel!! Eu sempre fui aquele que me entreguei muito, muito ao Gianni, muito ao jogo do Gianni, muito, muito, muito...

Voltando ao Mambembe, vocês tinham aula de canto, dança, como era??

De tudo, aula de tudo, aula de dança, de canto, de tudo.

Então vocês ficavam praticamente ensaiando o dia inteiro?

Nós ensaiávamos no Copacabana Palace. (um breve silêncio e ele ri, recordando) Olha foi um período que é difícil realizá-lo aos nossos olhos o que foi aquilo. A única tristeza que eu tenho em tudo isso é o Gianni ter dito no documentário dele que nós não queríamos fazer o Cristo Proclamado. Ele disse sim: - Não, todo mundo era contra, até o elenco também era contra a esse projeto. E isso é uma injustiça! Ah, eu acho uma 
injustiça, já falei isso no meu programa. Acho uma injustiça porque nós nunca deixamos de fazer o que ele queria fazer.

Nós amávamos muito o Gianni, infelizmente terminou o Gianni com a idéia de que nós não o amávamos. 


\section{Entrevista com Fernanda Montenegro (agosto de 2006)}

Mexendo num quarto que eu tinha na casa em que eu morava eu encontrei os 13 croquis (do Mambembe). Eu enquadrei, e fiquei com aquilo anos na minha casa. Depois quando tudo já começou a dar cupim, aquela coisa toda no material, nós passamos cerca de 8.000 documentos para a memória do teatro que foi criado naquela ocasião. Sérgio não deu nada, né? Pois é nós passamos tudo isso pra FUNARTE, documentos, contratos de teatro, contratos de atores, rescisões de contratos, cartazes, toda a vista nossa até aquele momento, teatro dos sete até aquele momento tudo isso foi pra FUNARTE. Fotos. Não sei se ainda está lá, pois aí veio o Collor. Aquilo tudo virou caixotes, por que ele desmontou toda a estrutura cultural do teatro no Brasil. Então não sei se ainda está lá.

Aconteceu o seguinte, o Ratto depois que nós dissolvemos a companhia ele nos ignorou. Não nós! Ignorou o trabalho que fez para o Teatro dos Sete. Que na verdade foi um grande trabalho da vida dele. Depois ele fez espetáculos, ele fez óperas, mas nunca mais, nunca mais na vida dele ele teve um grupo em torno dele, "magister dixit". Altamente disciplinado, altamente entregue, altamente, como é que eu posso dizer, altamente aderente, e crente, e voltado para aquele homem, porque ele é fascinante, ele era um homem fascinante, poderoso na sua visão de artista compreende? E isso nos ficou durante, entre 1954 até 1966, foram doze anos entre trabalho com a Maria Della Costa, com a companhia, trabalho com o TBC e o teatro dos sete. Mas é interessante, como ele, de uma certa forma refugou, tanto que no obituário dele não consta nada do Teatro dos Sete, nada, nada. Não existe. Também como o Rio de Janeiro é descuidado por "n" razões inclusive econômicas de cuidar da sua memória cultural, agente acha sempre que república do Brasil, não se sabe vamos em frente. E como São Paulo disciplinarmente e também economicamente, cuida, embora se queixe muito, mas cuida muito mais que qualquer outro estado do país da sua memória. A gente tem a impressão de que só as coisas que acontecem em São Paulo é que tem vivência. Por exemplo, você lê a história do teatro brasileiro através de São Paulo, tudo nasceu de 48 pra cá. E a gente sabe que o Rio de Janeiro, e também Bahia, e também Minas Gerais compreende? E também Recife, e também Pernambuco, veio pela história do Brasil funcionando culturalmente e sedimentando um Brasil que deu nisso que é hoje no ponto de vista cultural.

Então, é interessante isso, porque eu tenho certeza que não se vai se falar no Teatro dos Sete nessa época. Como não se falou no filme dela (Antonia). Ignorou-se esse período do Ratto.

Mas eu fui... Eu e Fernando nós fomos duas pessoas. Assim... Feitas pela cabeça do Ratto, porque nunca deixamos de reconhecer nele o homem extraordinário de teatro que ele foi. Eu até estou fazendo também um livro aí que estão me pedindo, e naturalmente de São Paulo. Aqui não se faz,.... Aqui não se pensa. Deixe eu ver, olha eu tinha separado tanto e acabei ah, meu Deus, pêra aí. Mas eu vou achar. Você quer desligar..Não a burra eu acho que.... 
Eu digo aqui, por exemplo: “O Ratto me deu consciência, a visão altamente artística, a utopia também para o teatro, e algo que sempre está além que a gente vai alcançar daqui a pouco, e não pára de procurar porque todo dia a gente se experimenta e se propõe" Isso aqui são coisas que eu estou escrevendo sobre ele.

È verdade que ele ficou magoado quando a companhia se dissolveu?

Mas nunca existe mágoa de um lado só. As mágoas no fim de um casamento elas são de ambos os lados. E cada um tem suas razões absolutas. Mas isso não impede que você reconheça o tempo, o que, o que, por que se a gente trabalha 12 anos juntos é porque alguma coisa acontecia de bom. O rompimento, o rompimento, na verdade, no fundo, se deu muito mais por ele do que por nós. Por que numa determinada época, muito em convulsão política no país, mas uma coisa... foi quando o Brasil mudou. Porque era, era... A coisa começou com a renúncia do Jânio, a não posse do Jango, parlamentarismo, Jango toma posse, os militares vão em cima. Então esses acontecimentos, só quem viveu sabe o que foi isso. Não se tinha condições, no Rio de Janeiro, que era a capital da República, ou ainda meio capital da República não se tinha condição de se chegar ao teatro, nenhum teatro. Tudo parou, as ruas viviam com gás lacrimogêneo, a embaixada da América ainda era aqui do lado do Teatro Ginástico. Era, sabe a gente escondendo jornalista dentro do escritório do teatro Ginástico. Foi um horror aquilo, foi um horror aquilo. E numa hora nós tivemos que sentar... porque a nossa companhia, que na verdade era um grupo de trabalho com esse homem poderoso e um extraordinário artista. Como acontecia sempre com a programação, porque se, se ... porque teatro não é uma coisa, uma ciência exata. Você faz $\mathbf{O}$ Mambembe. Um extraordinário sucesso. Sra. Warren, um extraordinário sucesso, aí vem Cristo Proclamado, 35 atores, foram todos pro Piauí, com a diretora musical, com um material fotografado, não sei se foi até filmado, fotografado certamente. Trouxemos um material de trabalho imenso, intenso, parecia até uma coisa estatal, parecia uma companhia estatal. Fizemos um espetáculo maravilhoso, só que num teatro errado, dentro do Copacabana Palace, que era o teatro que a gente tinha na época, não era uma sede nossa, não tivemos nunca uma sede nossa. Sonhamos com uma sede nova... nossa. Nós requisitamos em Brasília um terreno, até iríamos para Brasília trabalhar lá. Chegamos a fazer o projeto do teatro em Brasília. Olha bem, e conjuntamente com isso o Ratto, e naturalmente que tudo era conversado entre nós cinco (Fernanda, Fernando, Sérgio, Ítalo e Gianni). Começamos uma, uma .... cursos de teatro onde surgiram Irene Ravache, Gracindo Júnior, o Vereza, tô me esquecendo de alguém, enfim....Tetê 
Medina. Se não me engano tinha também junto algo sobre cenografia também. Então aquele Teatro Ginástico era uma escola, comandada por ele, compreende? Organizada por ele. A Pulga Atrás da Orelha, que entrou no lugar de Cristo Proclamado, foi um sucesso de um ano. Enquanto isso ensaiávamos a Megera Domada, entende? Isso tudo com dinheiro de banco, e com crise política. Hoje em dia é diferente.., eu fico pensando como fomos loucos, corajosos!! Eis que quando Ratto se apresenta para nós e diz o seguinte que ele não tinha vindo ao Brasil, palavras dele juro por Deus, pra fazer aquele repertório que ele estava fazendo conosco. Que ele propunha que a gente fizesse um teatro mais, vamos dizer mais acessível, que não ficássemos entrando nas ambições, ou Becktianas, ou Brechtianas, numa outra...e isso ele faria com os alunos , com, com o grupo que ele estava já organizando, ou sonhando, dentro do curso de teatro. Ao que nós respondemos, mas nós já estamos endividados. Nós não pensávamos, nós não pensávamos em dinheiro, entende? Não adianta achar que se faz teatro, principalmente enquanto sonhos, mas depois esses sonhos tem que trazer uma realidade, não é isso? Tem que trazer uma realidade. Quando nós terminamos essa reunião, nós vimos que ele não queria mais a gente. Eu acho que ele tinha, com todo o direito, esgotado, ou o trabalho que o entusiasmou até ali, e queria partir para outra. Mas nós não poderíamos assumir, eu digo nós os outros quatro, uma base de investimento dessa ordem pra este sonho, porque já não estávamos dando conta economicamente, embora com casas sempre lotadas, e tudo porque éramos quase nunca menos que vinte, vinte e cinco pessoas contratadas, entre atores e técnicos. Produções com cenários enormes, indumentárias, figurinos. Nós não tirávamos um tostão da bilheteria. O Gianni Ratto, com toda, com todo o direito, porque ele só fazia aquilo, ele tinha o salário dele, com todo o direito. Nunca deixamos de achar isso em conjunto, compreende? Mas nós ainda trabalhávamos na televisão pra gente poder comer dali e jogar o que pudéssemos, em vez das nossas retiradas, aquilo ia para as produções. Veja bem como nós tínhamos...Nessa famosa postura dele nós vimos que nós tínhamos...já tínhamos feito a nossa vida. Ainda fomos para o Maison de France, porque apesar de toda essa crise política, apesar de já um endividamento imenso, imenso que nós tínhamos. Porque a gente ia no banco e a gente pagava o papagaio, a promissória. Não se tinha dinheiro de governo, nem pensar. Mas o dinheiro que entrava, pagávamos a produção, não tínhamos... Não pagávamos a produção. $\mathrm{O}$ dinheiro que entrava pagava a manutenção. As produções a gente amortecia e íamos indo. Mas nessa convulsão social, não tínhamos mais para onde apelar. Mesmo assim, saímos do Ginástico nesta época e, 
estávamos com um sucesso imenso que era O Beijo no Asfalto, mas estreamos em junho, julho, em agosto o "louco" renunciou". Naquela corrupção toda era exatamente o período de renovação do Ginástico, que cobrava 30\% do bruto. Duas ruas depois, duas avenidas depois, tinha a Maison de France que na época eles nos entregariam o teatro pra nós por $8 \%$ do mínimo. Parece que falar disso, compreende?.. é descer a conversa, mas não é. De comum acordo fomos pra Maison de France, nos contratamos na Maison de France. Só que o painel do cenário de Beijo no Asfalto... Isso já com o público desesperado, toma posse, não toma posse, vem Brizola com o Rio Grande esperando o cunhado chegar da China pelo Uruguai pra vir com as tropas qual Fidel Castro, pelo Sul a fora pra tomar o poder, Brasília. Tudo isso...você não tem noção!!! O Ratto teria que cortar exatamente $20 \mathrm{~cm}$ do painel atrás do cenário, o cenário era dele, cenário maravilhoso! Mas tinha um painel atrás, uma espécie de rotunda que teria que ser cortada $20 \mathrm{~cm}$. Ele disse que não cortaria. Tudo bem! Não tem problema, não levantamos nenhum problema. Paramos a companhia. Na época deveríamos ter umas 20 pessoas contratadas, vamos procurar outros textos e vamos montar. Isto entre setembro, agosto, setembro, outubro e novembro. Então escolhemos Festival de Comédia. Festival de Comédia é PHD do Teatro dos Sete. O Festival de Comédia é o PHD do grupo. Quer dizer o espetáculo, assim, resultado de doze anos de trabalho com um artista chamado Gianni Ratto. Mas eram três peças, porque era um Cervantes, um Martins Pena e um Molière. Eram três montagens. Evidente. Mudança de cenário, uma equipe lá atrás enorme, compreende? Isso também, mais uma vez, se mantinha mas não pagava produção. E fim de ano, numa crise geral a ponto de, pela primeira vez... e houve isso, o Castelo Branco doou uma verba pra ajudar o teatro brasileiro, pelo menos aqui no Rio se ganhou, foi uma divisão entre as companhias desse, tal a crise que estava... fim de ano, ele já tinha..... Isso já foi no ano seguinte, no início do ano seguinte, pois ele já tinha tomado posse. Olha, então fomos, ficamos ali, ainda fizemos O Homem a Besta e a Virtude, de Pirandello, na Maison de France, mais uma vez... aí era política e campeonato de futebol. Então o que nós fizemos, saímos em excursão pelo Brasil. Fomos pra Porto Alegre e viemos subindo. Não é isso? Ficamos dois meses em Porto Alegre com aquela companhia imensa, hospedados onde foi possível a gente se hospedar. Porque nós tínhamos uma vida muito comunitária, por isso que estou dizendo, antes de ser uma companhia era um grupo de gente que veio junto também, veio vindo junto. Fomos para o Paraná, e quando voltamos para o Rio de Janeiro mais uma vez não tínhamos dinheiro. Então vendemos um gerador de luz, não é isso? Que 
tínhamos comprado do Piccolo Teatro, uma coisa assim, que tinha passado por aqui. E aí eu estava grávida, o Ratto foi dirigir a Tônia e o Paulo num Feydeau. Ficamos muito espantados porque ele achava que nosso repertório não estava à altura dele. Ele foi dirigir um Feydeau. Tudo bem! Teria sei lá que se manter, e ele fez um espetáculo extraordinário também. Inclusive nos convidou para participar do espetáculo com a Tônia, eu já grávida. Ele convidou Sérgio, Ítalo e eu pra irmos pra fazer a peça do Feydeau com Tônia e Paulo. Eu não tinha condição, eu tive uma gravidez de risco. Eu fui operada durante a minha gravidez, eu tive hemorragia quatro meses. Ficamos fazendo uma televisão pra gente poder comer. A dívida lá caminhando, na conversa, não é? Quando nós retomamos, nós retomamos com a Mirandolina. A Mirandolina era um elenco menor, mas tínhamos lá atrás, nove, nove técnicos. Então voltamos a ter uma companhia de perto de 20 pessoas. A Mirandolina foi um espetáculo primoroso, primoroso! Uma visão dele muito especial do Goldoni. Eu achava... Eu particularmente obedecia ele, e fiz aquele espetáculo com o maior carinho, ele nunca percebeu, ele nunca percebeu eu só disse isso numa entrevista. Quer dizer Eu achava que essa Mirandolina no Brasil deveria ser mais quente, mais colorida, mais século XIX sabe? Mas foi um exercício de estilo extraordinário. Um espetáculo pra você apresentar em qualquer parte do mundo, uma visão muito dele do que ele entendia. Ele tinha todo o direito. Ele era o diretor do espetáculo. Nós fomos entregues... Se há uma coisa que ele jamais pode dizer é que a gente se entregou a ele como crianças, compreende? Nessa altura engravidei da Nanda. Novamente hemorragias. Paramos. Fernando ainda dirigiu uma comédia americana. E aí nós fomos fazer um balanço da vida. Chegou a hora da gente se separar. E a gente se separou, compreende? O que havia de promissórias assinadas pagamos. O que não era de promissórias, por que nós fomos pedir mais dinheiro pra fazer, fizemos um grupo fora... Ele foi, nós nos dissolvemos, ficamos Sérgio, Ítalo, Fernando e eu. Fomos ao banco. pedimos a última chance pra gente sair daquilo. Ainda me lembro que no dia em que Sérgio e eu, porque Fernando, Fernando já não tinha condição e cara pra mais uma vez pedir clemência dos juros. Eu estou contando isso assim porque é importante que se diga isso, porque senão só fica um lado. Eu me lembro que no dia que nós fomos ao Banco Nacional na cidade, foi o dia da volta do Costa e Silva que ia ser presidente da república. Me lembro desse dia. Conversamos com o Juarez, Sr. Juarez que era o gerente geral do Nacional e ele nos deu, ele nos deu 5.000 qualquer coisa, que era uma merreca de dinheiro. Aos poucos, ele não iria dar tudo. Então nós fomos... E ensaiamos, mais uma vez, era um projeto do Gianni Ratto, 
de fazer A Parisiense de Henri Becke...Que ele gostaria de ter dirigido comigo, pra mim. Nós tínhamos essa peça lá de quatro, cinco pessoas. Dois filhos, Fernandinha acabou de nascer, Cláudio tinha dois anos, endividados. Uma situação econômica desastrosa, desesperada, nesse núcleo familiar. O Sérgio também devia ter o dele, o Ítalo também devia ter o dele. E esse caos, essas... famosas...como é .... os atos institucionais. Perseguição política, perseguição intelectual. Isso só pra chegar ao final como é que nós conseguimos... O que ficou ainda de dinheiro pra pagar nós fizemos $\mathbf{A}$ Parisiense, numa adaptação dos dias de hoje do Millôr Fernandes. Foi um sucesso estrondoso. Estreamos no dia 06 de janeiro de 1966, to lembrando agora. 66? Acho que sim. Caiu um temporal que o Rio de Janeiro caiu. O Rio de Janeiro desabou. Tivemos que parar. Foi uma coisa catastrófica assim... de ter desamparados dentro do Maracananzinho, todo mundo fazendo sopas, cuidando dos desgraçados, caídos no meio da lama, dos barrancos, dos barracos, enfim foi um caos. Retomamos uns quinze dias depois, paramos, mais uma vez paramos por causa da hecatombe na cidade. Era um teatro de 220 lugares. Nós fizemos terça, quarta quinta duas, sexta duas, sábado três, domingo três e em quatro meses nós sanamos todas as nossas outras dívidas de madeira, daquilo, daquilo outro. Pagamos, Não usamos todo o dinheiro que tínhamos emprestado. E com isso nós pagamos. Ítalo já estava se unindo ao Flávio Rangel, a Rosita Tomaz Lopes, Napoleão Moniz Freire e Célia Biar, foram fazer uma peça do Brecht. Sérgio, Fernando e eu continuamos. Fizemos O Homem do Princípio ao Fim do Millôr Fernandes, fizemos Harold Pinter, a Volta ao Lar. E fomos pra São Paulo, em 1967 fomos pra São Paulo e ficamos lá três anos. Então foi assim, compreende? Essa trajetória. Mas nunca deixamos de reconhecer a importância do Gianni Ratto nas nossas vidas. Na minha vida, na vida de Fernando ele é um referencial até hoje. Até hoje, também tem mais uma coisinha aqui....eu já misturei tudo aqui vocês não me levem a mal

(Há uma pausa para ela procurar em seus escritos coisas que ela já escreveu sobre o Gianni. Nesse momento pergunto se A Parisiense foi o espetáculo montado com o nome de A Mulher de Todos Nós e Fernanda confirma. Passa então a falar sobre materiais que teria para uma exposição sobre Gianni Ratto).

Por que ignoram tanto o Teatro dos Sete que não sei se isso vai entrar na vida dele. Eu não sei se vai entrar Sra. Warren (A Profissão da Sra. Warren), se vai entrar Cristo 
Proclamado, não se vai entrar Com a Pulga Atrás da Orelha, se vai entrar o depois o que se seguiu... O Festival de Comédia.

Foram todos cenários que ele fez.....

Tudo. O Beijo no Asfalto, Pirandello, O Homem, A Besta e a Virtude...Entende? Eu fiquei admirada. Como é que morre um homem desse tamanho, com essa dimensão, um homem que veio para o Brasil. Por que também tem outra coisa quando nós fomos fazer o teatro dos sete, ele foi muito, muito honesto conosco, porque ele tinha que ser porque nós éramos muito honestos com ele. Então nós tínhamos um sonho de uma companhia, assim, num mundo da loucura, não tínhamos nada, não tínhamos como. Ele, saindo do TBC foi pra Bahia, onde ele foi professor. Ficou lá. Quando terminou o contrato ele disse pra nós: quero voltar ao meu país. Estava casado com Luciana Petrucelli, que era uma figurinista maravilhosa. Eu tenho figurinos ainda... Eu também não vou dar isso... E também não sei se me devolvem isso. Ele disse com toda lisura eu quero voltar para o meu país, quero ver como é que está aquilo lá, porque ele tinha saído com a Itália arruinada em cinqüenta e...bom não tão arruinada assim mas enfim..., já tinha dez anos de Piccolo Teatro quer dizer não era ruim não, imagina, a Itália já estava vindo. "Eu vou ver como é que está a situação, como é que eu me sinto lá, como é que me recebem lá, e aí eu vejo se volto ou não. Então durante um ano... eu tenho até algumas cartas que não sei onde foram parar, a gente se trocou cartas. Tudo bem, estamos trabalhando na televisão esperando a resolução dele. Não fomos fazer nada de teatro porque não tínhamos como fazer nada com ninguém, a não ser com ele quer era a pessoa que fez a nossa cabeça. Até que um ano depois ele volta para o Brasil. Luciana Petrucelli não veio, ficou, mas mandou todos os figurinos da Sra. Warren, e os figurinos do Mambembe foram do Napoleão Moniz Freire. Aí ele disse que vinha, então vamos fazer a companhia. “Oh, vamos fazer a companhia”.Aí escolhemos O Mambembe. O Mambembe, ao todo tinha perto de oitenta participantes, entre a parte administrativa, entre maquinistas, entre o grupo de cateretê , o grupo de não sei que, mais um elenco enorme enfim, mais as camareiras,mais....

E a sugestão do texto foi sua, não é? 
Foi. Por que eu tinha lido aquilo. Eu tinha duas sugestões. Uma foi esse e outra foi $\mathrm{O}$ Homem do Princípio ao Fim, a peça do Martins Pena. Eu gosto de ler esses autores brasileiros que todo mundo acha que eles são nada. Quando a gente foi fazer o Mambembe, toda a esquerda né? Todo o país estava vivendo um momento muito complicado, era a mudança de capital, Juscelino terminando o Governo, entrando o Jânio, enfim as coisas apontando. Eu me lembro que Paulo Francis, quase cortou relações conosco, como é que nós iríamos fazer um autor bobo, um autor sem nenhuma expressão, enquanto que lá na Europa tinha Ibsen, Strindberg, e vai dizendo....tinha uma autor aqui que escreveu A Almanjarra, escrevia Um genro de Muitas Sogras. E interessante porque ao fazermos $\mathbf{O}$ Mambembe também...mas um elenco imenso. Ah, sim, tinha uma banda com seis músicos. Nós fizemos no Teatro Municipal porque, por acaso, veja como são as coisas, eram 50 anos do Teatro Municipal, que foi feito pelo Arthur de Azevedo, esse teatro maravilhoso aqui do Rio de Janeiro. E não tinha quem fizesse esse autor, por que esse autor estava sabe, lá nas calendas... Acabamos pedindo as roupas no Municipal, não é? Tínhamos feito assinaturas no programa de televisão, não sei se Sérgio contou isso. No Grande Teatro Tupi. Nós estávamos já há algum tempo fazendo um teleteatro semanal, com muito humor, com muito cuidado. Aí, não tem dúvida... O Sérgio Britto foi pro, imagine como éramos pioneiros nessa época na televisão, e disse "Olha esse grupo, o grupo idealizador e condutor do Grande Teatro Tupi, que vocês conhecem já de alguns anos, nós estamos pretendendo fazer um grupo de teatro, uma companhia de teatro. E queremos oferecer a vocês assinaturas pra que a gente possa ter um fundo pra começar a companhia”. Foi tudo claro. Em contrapartida nós damos quatro assinaturas, uma assinatura de quatro espetáculos. Uma assinatura de quatro espetáculos. Que seria O Mambembe, seria A Profissão da Senhora Warren, seria Cristo Proclamado, e seria Beijo no Asfalto.Nós levantamos um dinheiro bom, com uma mesinha aqui na Siqueira Campos e, essa gente de televisão que via nossos programas de televisão que ia pro ar assim umas dez e meia, onze horas da noite. Nós levantamos um capital básico. Agora não dava para os quinhentos figurinos, não dava! Ta entendendo? Não dava! Dava pra gente se estimular. Daí dissemos: vamos ao Municipal e vamos pedir emprestado as roupas do acervo do Municipal. E fomos recebidos pelo diretor do Municipal que disse - Mas vocês querem fazer...vocês querem fazer Arthur Azevedo? Nós dissemos - Queremos. - Pois então ótimo, porque ninguém quer fazer Arthur de Azevedo. Estamos comemorando os cinqüenta anos do teatro, então nós damos os figurinos, damos os cenários e ainda damos quinze dias no Teatro 
pra vocês. Foi assim que a nossa companhia começou. Por que não seria possível!! Então, tudo isso é história deste homem. Eu fico boba de ignorarem isso, de não falarem disso! Sabe? De não, de não, de não reconhecerem que esta foi a chegada de um extraordinário homem de teatro a este país, que com meia dúzia de seguidores da "chama eterna" compreende? Nós nos juntamos a ele e fizemos um trabalho de primeiríssima qualidade. Até hoje quem viu não esquece.

É, dizem que foi um marco do teatro "O Mambembe”, né?

Interessante que nós não partimos de musical, nós partimos de uma burleta, brasileira. Compreende? E depois nós retomamos um tipo de teatro brasileiro extraordinariamente bem feito pelo Gianni que foi o o..., no Festival de Comédia, o Ciúmes de Um Pedestre, do Martins Pena. Sabe é um espetáculo maravilhoso, foi um espetáculo maravilhoso! O livro do Kusnet sobre Stanislavski, vou dizer isso porque está lá, ele dedica a mim porque era uma farsa humanizada e quem me deu isso foi Gianni Ratto. Kusnet me dedica esse livro sabe que como, vamos dizer, o sentimento, a humanidade, enfim a memória sensível, o trabalho do Stanislavski pode entrar na farsa. Nós conversamos muito sobre isso com o Kusnet.

A forma de trabalho do Gianni, como o Sérgio disse era diferente, era um trabalho muito grande de "mesa", não é?

Ele não era como o Ziembinski, que fala o que queria, Ziembinski representava. $\mathrm{O}$ Ziembinski era um homem extraordinário, mas era um ator extraordinário também. Então, ele dava a fala. Ele queria que o ator repetisse o tempo dele, e os tempos dele, entende. O Ratto não, o trabalho do Ratto era estimular o teu imaginário, a tua sensibilidade e achar o teu cerne a serviço da cena. Completamente diferente! O Ziembinski seria quase que por mimetismo. O trabalho do Ratto não! O trabalho do Ratto era você entender pelo sentimento e pela razão o que ele estava pretendendo, o que ele estava buscando. Deixa eu só ver se eu acho isso aqui que eu quero achar, já saiu tudo de.... 
Em conversa com Gianni, muitas vezes ele ser referia a importância do trabalho do ator, independente do tamanho da personagem, como o exemplo de uma grande atriz, e eu já sabia quem era, que simplesmente passava pelo palco em uma determinada peça...

\section{Eurydice.}

E apenas com essa passagem mostrava toda a carga, a composição da personagem, que conseguia conquistar o público a peça era Eurídice, de Anouilh.

Isso, Eurydice. Em Eurydice eu fazia nada. Mas tem uma hora que ela prenuncia a morte do herói. Essas coisas, ele, sabe, você, ele te dava. Então não é só dizer... Se não me engano a frase era: Fulano, o nome não me lembro agora, o trem acaba de chegar, o trem está chegando. Eu tinha que entrar em cena, uma das atrizes da companhia, e dizer pro herói que era o, o... fulano, o trem está chegando. E saía. E ele vai morrer naquele trem. Compreende?

E toda essa emoção você tinha que passar nessa....

Tinha que chegar simples e criar uma coisinha, um ruído na cena, compreende? Mas isso porque ele nos deu isso. Por que ele me deu isso, compreende? Eu sou eternamente grata a ele. Era rigoroso. Eu me lembro que anos depois a gente se encontrou, e ele disse assim pra mim: Sabe, Fernandinha, não é? Eu o chamava sempre de Sr. Ratto e ele me chamava de Fernandinha. Sabe Fernandinha, eu não sou mais aquele espírito ditador, eu mudei muito, eu mudei muito, ele dizia pra mim. E nos encontramos algumas vezes. Nos encontramos em entrevistas pro Serviço Nacional de Teatro, no MAM em São Paulo numa outra ocasião, fizemos muitos depoimentos pra, pro filme. Almoçamos com ele uma ocasião aqui.....É, uma outra, que foi... gente..., jantamos, algumas vezes nos encontramos, compreende? Com muita, com muita, com muito carinho, com muito carinho.

Ele claramente, ele tinha muito carinho por você, era uma de suas atrizes favoritas. Tanto que ele contava muito também a passagem da montagem da Moratória, na Companhia da Maria Della Costa, em que ele queria que você fizesse a protagonista, e 
não a Maria que era a dona da Companhia, por achar que o papel teria mais a ver com você que com ela.

Pra absoluta surpresa minha, compreende? Ele tinha uma ética muito grande também. Ele não rachava companhias, compreende? Eu era recém chegada à companhia da Maria, substitui lá, fiz alguma coisa lá na Cotovia, depois fiz uma parte na Pulga Atrás da Orelha, e um dia me comunicaram que eu ia fazer A Moratória, Maria tava muito doente. E também eu agradeço muito a Maria, porque se fosse outra atriz diria Ah, não de maneira nenhuma, eu sou a dona da companhia....

Exatamente, ela foi muito generosa....

Quer dizer, houve um acordo ali, também, não é isso? E foi um trabalho revelador pra mim. Porque foi a hora que a gente... Eu vi que eu tinha um diretor, tem um outro trechinho aqui que eu dizia assim..., você vê se depois você usa ou não, "Nós não pensávamos pequeno, digo no Teatro dos Sete, a custa da nossa própria falência econômica, não pensávamos nos gastos de produção, no elenco numeroso com contratos de ano, elencos também de técnicos, inúmeros cenários e figurinos. Não imaginávamos para onde iria o Brasil com a renúncia do presidente Jânio Quadros e a mudança da capital para Brasília”. Houve uma hora em que ficou uma terra de ninguém esse país. E todo mundo sofreu com isso, não fomos só....

E ele aplicava, existia, além da leitura, algum exercício que ele dava pra vocês?

Olhe que eu me lembre, que eu me lembre...é....ele não fazia muitos exercícios corporais. O problema era vencer, mais do que vencer, era despertar a inteligência cênica da gente pelo imaginário. E depois também essa coisa do corporal, já é dos anos, dos anos, da segunda parte dos anos sessenta pra cá, compreende? Na contracultura, quando começou entrar os jogos de liberação de contatos físicos, compreende? $\mathrm{O}$ sensitive training, ta entendendo? É, isso é mais no fim, um pouco já quase o fim dos anos sessenta, e glorioso nos anos setenta até meados de... até agora. Eu me lembro que nós fizemos na Maria Della Costa um espetáculo do Sérgio Toffano chamado A Ilha dos Papagaios, em que a gente trabalhou fisicamente muito. tinha canto, já tinha 
alguma dancinha, compreende? Eu fazia a Duruk, que era uma negrinha, de malha, que tinha que pular numa perna, na outra, tinha que sair correndo... Então todos nós nos exercitamos muito fisicamente pra esse espetáculo, mas o grande trabalho dele era na massa poética do texto, era no entendimento psicológico, a inter-relação das personagens, o jogo das n possibilidades que uma cena possa ser jogada, entende?

E que hoje infelizmente é difícil encontrar um diretor que faça isso..

Hoje a grande deficiência que eu acho hoje cênica, é que os jovens atores não sabem falar. Mas não sabe falar na propriedade cênica, na propriedade daquela dramaturgia. Há também uma espécie de relaxamento com relação à dramaturgia. A propósito de uma peça faz-se um espetáculo, a propósito de um poema faz-se um espetáculo, a propósito de um livro, faz-se um espetáculo. Eu acho isso maravilhoso, eu não censuro isso não, eu acho que toda maneira de amar vale a pena, não é? Então parece que isso dá uma certa permissividade ao artista de ir por onde for, não é? Se não sabe resolver bem, corta-se, facilita-se. Ou então se endurece, porque não consegue e se enrijece, se estrangula, desloca as tônicas das frases. Não sei se ensinam isso nas escolas. Essa grande escola, eu tive com Gianni Ratto, que sempre evitou dar a sonoridade, vamos dizer a intenção,ele representar pra gente copiar.

Como teria que ser. Ele buscava em vocês, ele mostrava o caminho, dava os caminhos pra que vocês...

Lutava-se muito. Lutava-se muito. Mas se conseguiu.

Mas havia uma preocupação com o texto que hoje não há, não é? Hoje é o cenário, a luz.

Mas não se chega a isso porque se quer, não é? Eu acho que a educação primária é ruim, a educação secundária é ruim. Não se valoriza mais as leituras nos colégios. Há um desleixo com a leitura. Agora tem a informática. Também já está se mudando, já vai se passar pra outro tipo de linguagem, outro tipo de escrita. Então a gente não pode querer que o mundo pare, não é? Cada um...com sua época, compreende? Agora eu dou graças a Deus de ter vivido numa época em que o Teatro se estruturava numa dramaturgia. 
Porque isso é você se completar como ser humano por que...entende, fora da cultura vc é um animal bruto, não é? Você vive, respira e tudo.

Quer dizer, uma coisa que ele dava, que era uma coisa da época. Essa coisa de você ler livros, de você se...

Em torno daquela problemática você lia. Eu me lembro hoje ainda, que quando a gente foi fazer o Cervantes, ele trouxe um livro de pintura do século de ouro do teatro espanhol, e também com a parte pictórica da época. Aquilo imediatamente você percebe Ele trouxe e disse olha aqui essa figura, essa aqui, aí você vai e procura. Você começa a colocar seus livros, você se intera, você vai ver como eram as roupas, como era a sociedade, como era do ponto de vista, outros autores, envolta daquela problemática, toda uma base cultural de informação. Bom, isso não enriquece só a peça. Você, você abre espaço... O meu Deus que coisa linda, não é? Que coisa maravilhosa, como você se amplia, como você, enfim alcança, e aumenta a percepção pra outras coisas.

E nesse ponto, havia uma preocupação dele em inserir o ator também no cenário e no figurino da peça, não separadamente, mas com o objetivo de que ele soubesse disso pra construção da personagem, como que era?

Pois é? Por que era o seguinte: o cenário é esse, o figurino é esse. Você não ia pelo facilitário, assim, eu acho que aqui eu poria um chapéu assim, eu acho que, não é melhor diminuir esse degrau aqui, eu poderia entrar por aqui, em vez de por ali? Você co-dirige.... Uma pessoa que diz é isso aqui, e vamos fazer isso aqui, não é mimetismo também. E é um desafio, porque você pode ficar um autômato, não é? Um boneco bem cuidado, ou então você vai pra vencer o desafio, e existir no desafio. Ele nos ensinava a existir no desafio. Quando a gente fez Cervantes o Sérgio tinha que andar assim (ela mostra) e o Ítalo tinha que andar assim (ela mostra). Aquelas figuras de feira, aqueles desenhos do teatro da Espanha. Vai fazer isso agora. Era fantástico. É isso o que eu quero, e vamos fazer. É claro que pra fazer isso você faz os exercícios, você faz um aquecimento, você esquenta sua voz, e ficou, e fez, e fizeram. Eu nem sei se tem materiais desses espetáculos. Eu tenho, onde? Está tudo... Eu não sei se o Sérgio tem o Cartaz de $\mathbf{O}$ Mambembe assinado por todos. 
No livro dele ele comenta que foi escrito especialmente um prólogo e um epílogo pra esse espetáculo. Você não teria isso?

Será que o Sérgio não tem? Quem escreveu esse prólogo foi Cláudio Mello e Souza.

Eu te digo, porque assim, na minha dissertação, além de falar do Gianni, eu quero pontuar com espetáculos que foram marcantes na carreira dele, que foram, quatro espetáculos: O Canto da Cotovia, que foi o que o trouxe pra São Paulo, O Mambembe.

A Moratória, não pode esquecer A Moratória que ele lançou o Jorge Andrade.

Eu queria muito que fosse "A Pulga Atrás da Orelha", mas conversando com a Vaner (viúva de Gianni Ratto), ela me disse que ele não gostava da Pulga, por achar um espetáculo muito comercial.

É eu acho, que ele tinha um problema que era.... Mas era primoroso gente..... Eu vou te dizer uma coisa, quando nós viajamos para o sul nós viajamos com A Pulga Atrás da Orelha, Beijo no Asfalto e Festival de Comédia. Quando nós estávamos no Paraná o George Deville ${ }^{109}$. O George Deville foi o homem que fundou... Porque tinha o Old Vic em Londres, que era onde estavam todos os grandes atores ingleses, e tal Olivier, e pa pa pa, John Guilgud, ... O George Deville, ele fez, ele é o responsável pelo Pinter, pelos jovens atores, hoje já são todos velhos, o Finley, o Osbourne. Ele foi o responsável pelo Osbourne, e ele foi o responsável pela saída do Olivier do Old Vic pro Royal Court, onde ele conheceu a mulher dele, não sei como se chama, com quem ele se casou. Quer dizer ele tinha tal importância e influência no teatro inglês que ele criou o teatro moderno inglês, a ponto de o Olivier numa determinada hora sair para fazer Osbourne, pra fazer os autores contemporâneos, Pinter e o diabo a quatro. Este homem veio ao Brasil, e inclusive dirigiu uma leitura de um Pinter aqui no Rio com Cacilda, Zimbienski, e não sei quem mais, Festa de Aniversário, do Pinter, porque ele veio também por que a Cultura Inglesa, não, como é que chama o Conselho Britânico tinha interesse em divulgar esses atores novos, novos há quarenta anos. E ele foi mandado pra Cultura Inglesa, olha bem, em Curitiba, há quarenta anos atrás e a gente

${ }^{109}$ Provavelmente ela se refira a George Devine. 
estava em Curitiba e dizia "Mas o Deville está em Curitiba?" Ele deu uma palestra numa salinha pequena na Cultura Inglesa de lá. Aí fomos Cláudio Corrêa e Castro, Ítalo, Sérgio, eu e Fernando. Fomos assistir, não tinha ninguém, tinha umas quatro ou cinco pessoas lá. Quem é Deville? Falar de Pinter, Osbourne? Ele, quando a gente entrou, depois ele disse, ele ficou muito perturbado. Ele foi ali pra fazer uma palestra qualquer e ele sentiu na gente que a gente era de teatro. Ele sentiu. Bom, ficamos ligados, ele viu nossos espetáculos e viu Feydeau. Ele ficou "abismado" com a qualidade do Feydeau. Ele dizia assim: É fantástico, se nós fazemos Feydeau (referindo-se aos ingleses), nós vamos fazer um Feydeau a inglesa. Nós temos uma tal escola, nós temos uma tal herança cênica que por mais que a gente queira se libertar, a gente queira fazer, não consegue, porque a escola, ela marca a empostação, marca, tudo marca. Então se nós fizermos um autor francês nós vamos fazer um autor francês como se ele fosse inglês. Eu estou vendo este Feydeau absolutamente liberto, vocês são libertos. Não há uma escola, existe um espírito em cena, existe um deleite em cena, que não pertence, eu nunca vi, não sei que tipo de educação teatral vocês tem, mas vocês têm uma dinâmica cênica que é alucinante. Isso vendo Feydeau, dirigido pelo Ratto. Eu tinha uma hora que eu dizia assim para o Ítalo: Se você não fizer, ó (e batia uma mão contra a outra, como se fosse uma matraca de procissão). E ele (Gianni) olhava pra mim e dizia mas o que é isso? ( e repetia). Mas é ótimo isso! Como é que você faz? (e ela repetia). Entende? Eu acho que ele achava... Interessante que ele dirigia, mesmo achando que estava conspurcando ele dirigia, e dirigia bem.

Outro espetáculo que eu penso, que foi um marco foi "Gota d'água".

É, foi um marco. Olha no meu pensamento eu acho que foram: O Canto da Cotovia, A Moratória, Eurydice, você não pode imaginar o que era Eurydice, era um espetáculo! Dentro do espírito do Anouilh, porque essa peça é uma peça da guerra. A França ocupada. Ele fez uma peça pra baixo. Toda hora um ator dizia: Demora muito pra se ficar velho. Demora-se muito pra morrer. A morte demora muito. Era morte, morte, morte. Ele fez um espetáculo extraordinário. Não foi ninguém. Ensaiamos quatro meses, não foi ninguém. Era um espetáculo pra Cleyde e Walmor. 
Eu acho que o Gianni Ratto não mudou pela vida afora no Brasil. Ele sempre foi tocado pela arte, pela cidadania artística, pela transferência de um saber ou de uma luta pra saber as coisas da vida pra alguém que com ele trabalhasse. Mas eu quero dizer o seguinte que o Teatro dos Sete, o repertório do Teatro dos Sete, o que ele fez no Teatro dos Sete, o que ele organizou no Teatro dos Sete, os cursos que ele deu no Teatro dos Sete, quer de interpretação, ou de cenografia, sem dúvida nenhuma foram os melhores anos da vida dele no Brasil. Eu acho que ele pode ter tido na vida outros companheiros de vida, de arte, mas tenho certeza que ele nunca mais teve um grupo de gente tão ligada a ele, tão respeitosa a ele e tão produtiva junto com ele.

Qual que você a importância dele pro teatro brasileiro, como diretor?

Nós somos um país sem memória. Só não lembrar do Teatro dos Sete, é uma agressão ao artista da dimensão dele. Não sei até onde ele foi responsável por isso, por alguma mágoa que tenha ficado, mas como eu digo as magoas não são só de um lado, a obra dele foi muito maior. Então qual é a importância? A importância é que todos nós artistas que passamos por ele, desde os que já se foram, até agora, os que tiveram contato com ele, ou no plano de direção, o no plano de conselheiro, ou no plano de supervisor, na interpretação mesma, na dramaturgia mesma, passaram uma experiência para autores novos, atores novos, cenógrafos novos, quer dizer com quem ele esteve ele é inesquecível. Enquanto nós vivermos. E eu acho que retomar esse período do Teatro dos Sete, nessa hora em que se está fazendo um levantamento da vida dele, eu acho que sem esse período imenso e de alta qualidade de produção, se isso não for levado em consideração eu acho que é diminuir a figura dele. E onde ele estiver eu tenho certeza que ele não vai se envergonhar.

Todo grupo, principalmente de teatro, que é nossa área, tem uma hora que justifica o porquê existe. Eu acho que o Festival de Comédia, foi o somatório do que o Ratto pretendia em matéria de teatro no Brasil aos cuidados dele, ele sendo o mentor do processo. Eu acho que desde a Cotovia, desses doze anos de vida com ele nesse nosso grupo, eu acho que, se houve um espetáculo que o realizou, onde ele trabalhou e ele conceituou o seu melhor foi o Festival de Comédia. Eu acho também que os grupos, quando conceituam o seu trabalho, onde se soma o esforço de anos de todo mundo, ou de um mentor, ele deveria parar, deveria se dissolver, cada um buscar outro grupo. Porque há uma hora que tudo que é grupo fica estagnado. Então é preciso sair aquela 
gente e entrar outra gente, e cada um que sai desse grupo se junto a outro grupo, que é pra roda da vida continuar. Porque eu acho que os grupos que ficam sedimentados, as mesmas, os mesmos, os mesmos, os mesmos, ele se estiola, ele deixa de ter o frescor da descoberta. Todo mundo já sabe como é que o outro vai buscar seu processo, e todo mundo já sabe também qual é o processo que se vai chegar, todo mundo já começa a ter o cacoete de se servir de uma muleta, de não ter muito trabalho pra se chegar logo ao que o outro quer de si, e o de si quer do outro, então nessa insolvência, nesse final do Teatro dos Sete, eu acho que nós acabamos na hora certa. Cada um de nós foi pro seu tempo, foi pra outras ligações, todos nós, inclusive o Gianni Ratto, e foi buscar uma outra forma de se entrosar e continuar. Então, eu não vejo com nenhuma doença, nem com nenhuma, vamos dizer, carência, o fim de um, muito menos destes dos quais eu tenha participado na vida. Eu acho que há uma hora que a gente tem que acabar sim, pra poder renascer. Aquilo se esgotou. E eu tenho impressão que o Teatro dos Sete se esgotou. E teria sido a morte de todos nós se nós tivéssemos, pelo passado fingindo que está tudo bem, que tudo está maravilhoso, e não estando, compreende? E não estando. Já acha, um já acha que mais uma vez tem uma peça assim, ou mais uma vez eu vou ter que agüentar esse elenco, ou mais uma vez eu não vou ter a oportunidade de experimentar, sei lá, até para perder a cabeça em algum lugar.

Esse espetáculo (Festival de Comédia) foi o Phd do Grupo...

Eu acho que sim. Eu acho que sim. Foram três espetáculos, chamado Festival de Comédia, eu acho que é muito interessante isso né? Porque sempre se acha que o melhor não está na comédia. Era um espetáculo rigoroso, três séculos de teatro. Três pequenas obras primas. E a gente conseguiu fazer, e toda noite representávamos aquilo, e às vezes duas vezes por dia, e não se sabia onde buscar tanta energia pra se jogar daquela maneira. Naturalmente em nós mesmos, e principalmente neste estimulador artístico que era Gianni Ratto. Não sei por que esconder esse trabalho. Talvez Sergio Britto tenha essa crítica do Décio dizendo que foi o único espetáculo nosso (do grupo) que foi a São Paulo. Que nenhum diretor brasileiro conseguiria dirigir um espetáculo como o Festival de Comédia. Eu não me lembro do resto da crítica, e na época foi muito interessante, já que a gente está falando de coração, nós achávamos que talvez na onda dos jovens diretores brasileiros, não é? Isso foi em sessenta.........., sessenta e um, sessenta e dois, seria talvez um espetáculo estrangeiro, compreende? De um, e não 
inserido na onda do jovem diretor brasileiro que está fazendo espetáculos brasileiros, ta entendendo? O que também é uma outra bobagem. Mas eu espero que, eu leio, acho que conhecendo, não profundamente, mas bastante bem a crítica do Décio, eu acho que Décio fez um comentário muito, muito respeitoso e, realmente eu acho sim, que nenhum diretor naquela época conseguiria ter a disponibilidade, até mesmo cultural, para dirigir um espetáculo como aquele. Naquela época.

O que eu reivindico pro Teatro dos Sete, junto ao Gianni Ratto, não é uma coisa magoada. Tenho horror a magoado, não é isso. O que eu acho é que quem perde é a figura do Gianni Ratto. Porque ignoram seis ou sete anos de um trabalho intenso de um extraordinário artista junto a um grupo de atores não só os que estavam ligados na sociedade, como também um mundo de outros colegas que vieram e se juntaram a nós nesse trabalho. Então não é que se perca, não estou perdendo nada, porque sempre se fala disso, não escondo isso. Eu acho que quem perde é a figura de um criador como Gianni Ratto, por "ene" razões que eu não sei qual é, compreende?. Que nem na União Soviética o Stálin apagar a figura de todo aquele que não interessa ao processo.

O que o Sérgio fala é que a mágoa dele é quanto a Cristo Proclamado. Que ele diz que no filme, eu eu falei pra ele que não me lembro disso, talvez pra ele tenha tocado de uma outra forma, o Sérgio diz que o Gianni falou que os atores não gostaram da peça. E eu disse ao Sérgio que numa entrevista que fiz com o Gianni que ele disse que "o público" não estava preparado para uma peça dessas.

Ah, isso sim! Menino, não, o público do Teatro Copacabana. O pouco público, dizia o seguinte eu quero meu dinheiro de volta porque eu não vou ao teatro pra ver gente feia e fedida. Aliás, outro detalhe, a gente tinha tal entusiasmo pelo espetáculo porque era um espetáculo de vanguarda e com uma temática social intensa, que ainda não era comum no teatro brasileiro. Ainda tem essa, essa ... O nosso entusiasmo era tanto, que se tocava numa problemática social, de esquerda, que ainda não estava tão ainda explorado, ou vivificado em cena.

E foi isso realmente que, pelo menos a mim, o Gianni tinha dito, que era o público, e talvez tenha isso que o Sérgio tenha entendido, que alguns atores da companhia, pelo público não ter aceito, ter achado que não deveria ter sido montado. 
Não, isso não aconteceu. Aconteceu que nós, em comum acordo, resolvemos tirar porque não ia ninguém. Nós ficamos dezesseis dias, dezesseis dias, com meia dúzia de gatos pingados, nós tínhamos mais atores, tínhamos trinta e cinco atores. As pessoas contratadas por ano, não tínhamos, não tínhamos como sustentar aquilo, não tínhamos. Mas não que não quiséssemos fazer, pelo contrário, se gastou muito dinheiro na produção, uma equipe foi para o Piauí, ficou lá não sei quanto tempo, nós cantávamos as canções folclóricas todas, as incelências todas ensaiadas todas pela Dona Geni Marcondes, que era uma musicista e uma autora também, não, isso nunca houve, nunca houve... A única coisa, que também não comentei nunca com ninguém, a não ser, sobre A Mirandolina, não porque eu não tivesse, eu me entreguei àquele papel. Eu achava que aquilo podia ter um pouco mais de sangue, compreende? Mas isso é um direito que a gente tem, nunca discuti isso com ele, porque em primeiro lugar ele era o diretor, ele tinha aquela visão, não é isso? Não ia me contrapor, porque não, não estou dirigindo, não é? Tal a nossa entrega. Mas tudo bem. 


\section{Entrevista com Barbara Heliodora}

04 de agosto de 2006.

Eu sou super fã do Gianni. Eu acho que ela era uma pessoa excepcional porque ele era muito completo como homem de teatro. Ele estudou um pouco de arquitetura, a mãe dele ensinava canto, ele era cenógrafo, quer dizer eu acho que o segredo dele é que ele via o teatro por todos os lados, então eu nunca sei se ele foi melhor como cenógrafo, como diretor, ou como professor, porque em tudo ele era ótimo. E eu acho que ele ficou apaixonado pelo Brasil, passou o resto da vida aqui realmente, mas... então ele passou a compreender muito bem os brasileiros mas sem nunca abrir mão da disciplina que ele achava necessária para o teatro que era uma coisa mais da tradição européia, mas então para ele teatro era uma coisa muito séria. Compreende? Teatro não é lugar de brincar, teatro é uma coisa a ser feita com muito amor, com muita seriedade, com muita disciplina, então eu acho isso eu acho que nele era maravilhoso.

E eu tive a sorte ter convidado ele para ser professor no Conservatório que virou Unirio, não é isso? e eu vi que maravilha de professor ele foi, que os alunos ficavam encantados e aprendiam muito porque ele realmente era um professor inspirado. E ele dirigiu um espetáculo maravilhoso no conservatório, $O$ Auto da Alma mas foi uma coisa fantástica, ele realmente era um grande professor, como era um grande cenógrafo, como era um grande diretor. De maneira que isso, e acima de tudo, e além disso tudo tinha senso de humor, uma coisa preciosa de maneira que então as minhas lembranças de Gianni são de uma imensa admiração porque tudo que ele fez era com um Amor ao teatro, um amor que sabe que ter amor não é fazer bobagem, não é facilitar. Ao contrário, quanto mais amor maior a exigência, porque você quer um resultado que dignifique o teatro. E é isso o que ele fazia. Para ele o espetáculo era sempre uma coisa a ser criada com muito carinho, muita disciplina, e verdade teatral. De maneira que sempre fiquei com essa impressão do Gianni, E acho que de um modo geral tudo que ele fez com o Teatro dos Sete, desde que ele chegou, o primeiro espetáculo que ele dirigiu no Brasil com Maria Della Costa, O Canto da Cotovia, foi inesquecível, foi uma coisa fantástica, realmente foi um espetáculo de uma beleza, uma coisa incrível, e muito bem dirigido, e engraçado acho que foi um ponto crítico na carreira de Sergio Britto. Por que o Sérgio, que tinha estreado num Hamlet, medíocre, não tinha nada de excepcional, ao contrário tinha um Sérgio Cardoso, que era um esplendor, e o Sérgio Britto não, era muito modesto, então o caminho da composição do personagem é que foi o que realmente abriu o caminho para o Sérgio Britto no teatro. E ele fazia o Delfino (Delfin) no Canto da Cotovia, maravilhosamente bem, e daí é que ele começou a fazer papéis de composição até chegar ao amadurecimento como ator que ele chegou hoje em dia. De maneira que eu acho que ele aprendeu muito com Gianni Ratto e que isso, quer dizer ele foi um professor para uma porção de gente. Ele formou uma geração. Mas é porque ele tinha essa visão completa do teatro completa, ele via o equilíbrio entre o texto e a encenação, ele não dava preferência nem ao texto nem a encenação ele sabia que o teatro é bom quando tudo está junto. O teatro é um quebra-cabeça em que todos os pedacinhos têm que entrar no lugar, e fazer o que deve. Aquele negócio que sempre dizem que não adianta o ator principiante entrar em cena e dizer "Está servido o jantar" (empostado) por que isso estraga o espetáculo, não ajuda ele, não faz nada. Cada um tem que fazer sua parte, dentro da medida de sua parte. E isso, e o primeiro ator não tem mais nem menos obrigações que o último dos figurantes, cada um tem que fazer a sua 
parte direito. Isso é que o Ratto tinha. Essa preocupação com o todo, não adianta fazer um papel ótimo e o resto horrível, não! Você tem que equilibrar o espetáculo para ele ficar realmente harmonioso e significativo.

\section{E o Mambembe?}

O Mambembe foi inesquecível, eu me lembro do Mambembe como se estivesse passando na minha frente, ao vivo e a cores. Por que foi o uma coisa inacreditável. Eram 14 cenários. Cada cenário que aparecia o teatro vinha abaixo de aplausos, porque era uma coisa inacreditável, o primeiro era o fundo do armazém, onde eles se encontravam, era maravilhoso a gente via tinha réstia de cebolas, tinha isso, tinha aquilo tinha caixote, e............Tudo pintado, pura cenografia italiana. Mas no final tinha a festa do divino com o "coiso" de bambu, o coreto. Era uma coisa maravilhosa. Tinha tudo, e tinha o bonde que vinha de Santa Tereza que o Ítalo, o bonde saía correndo e o Ítalo ia atrás pra pegar o trem, e andava... E a minha impressão da estréia do Mambembe é que foi uma coisa tão extraordinária de alegria, de olha que coisa linda que eu sempre digo que as pessoas se encontravam no intervalo se encontravam e diziam "Como vai você? Você está bem? (sempre rindo) Porque era contagiante a alegria do espetáculo. E o espetáculo acabou, o que? Umas onze e meia, ou algo assim e eu me lembro que só saímos para jantar, porque eu saí com eles, do teatro, já passava de duas horas. O que tinha de gente pra cumprimentá-los era uma loucura. Foi um marco. Só sinto que não haja o DVD do espetáculo, porque era uma aula do que deveria ser feito para montar o Arthur Azevedo. Era realmente, figurino, cenário, interpretação, tudo, tudo, tudo. Era uma coisa maravilhosa, e foi ...O Ratto é quem dizia mas era nosso cartão de visitas, a primeira coisa do Teatro dos Sete. Então tinha que agradar, então foi mas que cartão de visitas. Foi sensacional!

\section{Outra coisa, e o polêmico Cristo Proclamado?}

Eu já briguei, discuti e não sei que, cem mil vezes. Eu que adoro o Chico Pereira da Silva (o autor), acho que a peça não funciona. Acho que o problema é com a peça. Acho que o paralelo do sofrimento do nordestino com o sofrimento de Jesus, que o Chico não conseguiu dar uma vida teatral válida a esse problema. Então o espetáculo não funcionava, não funcionava porque não havia jeito de fazer funcionar isso é que eu acho, não é que estivesse mal feita. Daí eles ficam revoltados, dizem que o público é que não entendeu. Não adianta!! Não era vanguarda coisa nenhuma. Era um espetáculo muito bem feito de uma coisa que não funcionava. Eu lembro a minha sensação na noite de estréia. É uma coisa que raramente a gente sente, um grande buraco entre a platéia e o palco. Sabe, como quando o espetáculo não chega? Não adiantava nada na vida aquilo. E eu adoro a maior parte das coisas do Chico Pereira da Silva. Mas pra mim o problema é o texto. Eu acho que nessa peça ele não conseguiu fazer funcionar a idéia. Então por mais que você fizesse, e eles fizeram com um cuidado enorme, mas foi um fracasso retumbante. Mas realmente acho que a culpa não é deles, nem dos atores, nem do Ratto, eu acho que infelizmente o texto não funciona. Eu acho que esse é o segredo do fracasso do Cristo Proclamado, que aliás o título é lindo! Mais bonito que Cristo Proclamado é impossível. O texto não funciona.

E voltando antes. O Gianni também foi um grande inovador ao colocar em cena a primeira peça de Jorge Andrade, A Moratória. 
Pois é, bom, mas isso foi muito engraçado. Porque nos Comediantes, foi um polonês, o Ziembinski que disse assim "Ó vocês tem uma peça brasileira ótima pra montar que é o Vestido de Noiva". Porque Os Comediantes, o repertório deles era de peças inglesas, francesas, não sei que não sei que lá, e foi o Ziembinski é que disse, "Mas tem uma brasileira ótima aqui". E no teatro da Maria Della Costa que ele (Gianni) estreou com o Canto da Cotovia, e tudo isso, ele é que pegou a Moratória do Jorge Andrade e disse mas aqui tem uma peça brasileira que vale a pena montar. E ele fez uma coisa ainda mais fenomenal que foi persuadir a Maria Della costa que era a dona da companhia a dar o papel a Fernanda que estava despontando, ali é que ela foi revelada mas ele entendia que o papel não era para a Maria, e que a Fernanda poderia fazer muito bem e com isso a peça iria funcionar muito bem. E realmente a cenografia dele foi maravilhosa, separando as casas. Que era o mesmo cenário com mais riqueza e mais pobreza. Era a mesma família que morava, mas depois que faliram então as coisas eram pobres em vez de ser ricas. Mas foi uma contribuição. Por isso que digo que o Ratto foi interessante porque ele se interessou pelas coisas brasileiras, ele se interessava por ter eventualmente autores brasileiros, ele se integrou muito no Brasil, mas sem perder as exigências clássicas do europeu.

Ele falou muito pra mim, no livro ele também fala, sobre a coisa do ator. Que ele precisava conhecer o ator para desenvolver a personagem. Cada ator é diferente, não se deve tratar a todos do mesmo modo.

Sim por isso é que ele dirigia bem. Você não pode dá uma forma porque as pessoas reagem de formas diferentes. Ele estabelecia um relacionamento diferente com cada temperamento.

\section{E o festival de Comédia!}

Ah, esse foi uma aula de teatro. Uma aula de teatro. Era um Cervantes, um Molière e um Martins Pena. Foi fantástico. Uma coisa inacreditável.

Engraçado que naquela época se você perguntasse a $99 \%$ das pessoas que iam ao teatro naquela época, ninguém falaria de Gianni Ratto, porque não tinha idéia do que era diretor. Especialmente porque Gianni era um diretor tão bom que não precisava fazer gracinhas pra dizer "Esse é um espetáculo de Gianni Ratto". Como acontece hoje em dia "esse é um espetáculo de fulano". O Ratto não, ele era um diretor maravilhoso. A direção melhor tem que passar despercebida.

Muitas vezes o criticavam por ele não ter um estilo. Mas ele dizia que não, pois cada peça é diferente.

Mas o Michel St. Dennis é que diz uma coisa muito boa. Que diz que uma vez ele falou de estilo e quase levou um murro. Porque as pessoas diziam que era uma coisa artificial. E ele dizia que não, estilo é fazer o que a peça pede. Então isso é o que o Ratto fazia é fazer o que a peça pede, não inventar uma gracinha do diretor. Colocar uma luz verde com uma luzinha amarela, não tem nada disso não. Ele não estragava o espetáculo, ele construía o espetáculo para chegar ao público.

E voltando ao Festival de Comédia? 
Foi fantástico. O Sérgio Britto e o Ítalo Rossi fazendo os dois velhos no Cervantes era fantástico. E o ítalo fazendo o médico volante, o que ele subia e descia, aparecia aqui, aparecia ali.

O Sérgio realmente falou, que quando ele lembra não sabe como era capaz de fazer aquelas coisas.

Feito um dia que não sei quem bateu com a cabeça em "Com a Pulga Atrás da Orelha" e naquele segundo ato que já é uma correria ficou faltando um, e a correria ficou maior ainda, porque não deu tempo de chegar para a cena, acho que foi o Loureiro, ou um deles que bateu com o olho, e então ficou faltando um na correria. Eu sei que o ítalo, pra mudar de personagem tirou o casaco e jogou e ninguém achava, foi parar na segunda varanda do cenário. Que desespero!! Uma coisa. Foi uma época privilegiada. Por isso é que eu digo quando as pessoas me perguntam como é que se forma um crítico. Eu acho que hoje em dia agente não vê um espetáculo para formar um crítico. Nós, a minha geração e a geração abaixo de mim, fomos privilegiados porque vimos teatro.Foi Morineau, os Comediantes, o TBC, Dulcina, etc., Houve uma variedade de espetáculos grandes, então você podia aos poucos construir seus referenciais, ver uma porção de coisas diferente. Hoje em dia quando tem três personagens é uma super produção. È monólogo, monólogo e monólogo. Então, falta você ver autores estrangeiros clássicos, não vê mais montados como eles devem, com respeito. Numa comédia clássica, quando o material é engraçado não se faz graça. Como crítico você leva para o teatro a sua experiência de ver espetáculos.

Qual foi a efetiva contribuição de Gianni Ratto para o teatro brasileiro?

Não tem dimensão. Como diretor, como cenógrafo e professor, ele contribuiu para a profissionalização do teatro. Porque eu acho que o problema é que você tem que deixar de ser amador para ser profissional. Porque esse culto do amador é pra quem fez teatro seiscentos anos, e tem um grupinho que vai não sei aonde e faz coisas. Nós precisamos é de profissional. É não se atrasar como se atrasa, que todo mundo seja responsável na hora de representar. Eu acho que o Ratto foi uma aula de teatro ambulante. Quer dizer eu acho que ele ensinou, foi um degrau no desenvolvimento do teatro brasileiro e ele fez uma contribuição monumental por ser bom cenógrafo, por ser bom diretor, por ser bom professor. Então acho que isso, quer dizer, nós devemos muito ao Ratto porque ele foi realmente..., e muito generoso na transmissão dos seus conhecimentos de maneira que tudo isso conta. Ele fez coisas realmente, ele deu grande contribuição. Ele era maravilhoso. Maravilhoso!! Esse ensinou muito!!! Vou lhe contar uma coisa linda do Ratto: Uma vez encontrei com ele e ele perguntou de um espetáculo que tinha estreado. $\mathrm{E}$ eu disse, Ah, é muito ruim. E ele, puxa que horror, as pessoas, cada espetáculo ruim prejudica todo o teatro. Inclusive porque tira a platéia, porque quem vai a um espetáculo muito ruim não volta durante muito tempo ao teatro. E então ele disse assim, é uma pena as pessoas precisavam lembrar que cada espetáculo afeta toda a atividade teatral. Ele tinha consciência de que tudo era importante.

Jean Louis Barrault disse a coisa mais maravilhosa que já ouvi na vida, fazendo uma palestra aqui no Teatro Municipal, ele disse assim: Para ser ator é preciso que se tenha uma razão mais forte do que querer encontrar uma profissão se acorda mais tarde. 


\section{Entrevista Aimar Labaki}

$25 / 09 / 2006$

A última direção dele (Gianni) foi um texto meu né? Vermouth.

$\mathrm{Eu}$ acompanhei esse processo inteiro desde ele trabalhando o texto, e eu aprendi pra caralho com isso, até o processo de ensaio e a temporada. E ele já estava fisicamente debilitado, ele tinha dificuldade em sair da platéia e subir ao palco para dirigir os atores lá, então isso dava uma distância que não tinha antes, antes ele era muito elétrico, subia, tinha uma coisa mais física dos atores. Agora, você matou a pau, você foi na mosca, o trabalho dele, isso ele mesmo dizia - . E eu me identifiquei com isso, eu sou exatamente igual - eu não sou encenador, eu sou um diretor Eu não sou uma pessoa que trabalha a cena pela cena, eu escolho um texto que tenha alguma coisa que eu queira dizer, e o meu trabalho é explicitar esse texto em cena, e isso eu faço pelo meio mais importante que é o ator. O texto do ator é o foco do trabalho. E é exatamente isso, quando ele começou a trabalhar com o Vermouth houve uma primeira fase em que eu fui lá (na casa dele) e começamos a trabalhar o texto juntos. Eu escrevi muitas coisas em função do que a gente tinha conversado. E era muito interessante porque ele, em nenhum momento tinha aquela posição de "eu diria assim", a posição dele era "você queria dizer o que? Ah, é isso? Então isso não está claro. Tá vendo como aqui você diz uma coisa e ali não repercute..." Ele tinha uma visão de dramaturgia que era muito, nesse sentido também, técnico, quer dizer ele olhava o texto e queria saber o que o autor queria dizer, se aquilo estava bem explicitado ou não. A partir do momento que ele ia pra sala de ensaio ele tratava o texto como se fosse Shakespeare, antes ele me tratava como se eu fosse um cachorro. "Você não sabe nada, nã, nã, nã..., brincadeira, ele era extremamente respeitoso com o texto, quando ele apontava os erros...era extremamente respeitoso.Quando ele ia pra sala de ensaio ele não queria mais saber disso, aí ele não queria mais mexer no texto, ele queria fazer o texto exatamente como estava, aí era a briga dele com os atores, o texto fica decidido com está. Tem uma lógica nele, então vamos descobrir que lógica é essa. Tem um motivo para ser essa palavra e não aquela palavra, então vamos trabalhar essa palavra, e assim por diante.

Eu fico muito emocionado, uma vez eu estava numa gravação daquele programa do Sábato. O Sábato fez um programa que era entrevistando ele (Gianni Ratto). Estava Kalma Murtinho, eu e Eduardo Tolentino, e ao final o Sábato disse uma coisa que eu nunca tinha pensado, ele disse "Olha, nenhum diretor, brasileiro, ou não, foi tão importante para dramaturgia brasileira quanto o Gianni, basta você pensar que Jorge Andrade nasceu pelas mãos dele, foi ele quem, Décio de Almeida Prado apresentou o texto de um aluno dele da EAD, que era o Jorge Andrade, falou com o Gianni. O Gianni convenceu o Sandro (Sandro Pollônio) e a Maria (Maria Della Costa) a fazerem, para Fernanda (Fernanda Montenegro) fazer sua primeira protagonista, Jorge Andrade. Arthur Azevedo era motivo de deboche, era uma cariocada. Depois da montagem do Mambembe, entrou pra lista dos grandes autores brasileiros, e todo mundo reverencia, e monta e não sei o quê. Trabalhou com Guarnieri, trabalhou com Vianinha, "Se correr o bicho pega, se ficar o bicho come", foi feito ali; montou "Gota d'Água, naquele momento da ditadura, e aí Sábato, na fala dele começou a enumerar, e terminou dizendo, e termina com a nova geração que foi Aimar Labaki. Isso me deu uma sensação de pertencer a uma tradição, que é uma coisa pouco costumeira no Brasil, no Brasil é tudo geração espontânea. E na hora me emocionou muito. E me deu consciência 
da importância do Gianni para a dramaturgia brasileira. Com quem você falar que trabalhou com ele como diretor, a tônica é essa: que ele era muito bravo, que ele era muito trabalhador, e a preocupação dele era texto, e ator. É óbvio que como grande cenógrafo que ele era ele tinha soluções visuais pro espetáculo que eram muito boas. Então não é dizer que como diretor ele tinha uma deficiência do ponto de vista da organização da cena. Mentira, ele organizava muito bem. E por opção fazia com que esses elementos estivessem subordinados ao ator e ao texto. No caso desse Vermouth, por exemplo, ele tinha uma solução cênica bárbara de uso, primeiro porque ele não tinha dinheiro, era uma produção muito pobre. Independente disso ele teve uma solução de fazer um cenário em perspectiva que dava um efeito expressionista à cena e era absolutamente pertinente com a forma como tinha sido estruturado. Ele usava projeção de documentários sobre hip-hop, sobre o universo do hip-hop, documentários do Chiquinho e da Tata Amaral. Eram dois curtas que eles fizeram antes da Tata fazer um longa sobre o universo do Hip-hop. Na realidade tinha um recorte do que era a juventude na periferia. E ele teve a sensibilidade de usar esses curtas em projeção no início da peça, não era em cima... No texto eu pedia a utilização de uma música, a entrada era com uma música, e ele usou essa música... Olha tem uma coisa interessante que foi o seguinte, eu citava ali era Racionais $\mathrm{MC}$, era uma música do Racionais. $\mathrm{O}$ primeiro dia que fui trabalhar com ele , ele disse: "Olha, não conheço essa gente, nem sei o que é, você me traz". Gravei pra ele, ou melhor, minto levei o meu CD, que aliás se perdeu, ficou lá com ele.E aí eu me impressionei, porque depois de um tempo ele disse que estava gostando, que ele estava escutando aquilo. Ele já com 82, 83 anos, e era um homem que escutava Bach todo dia que tinha uma relação com música, e com ópera, muito grande. E de repente teve a sensibilidade, ele dizia não gosto de tudo mas gosto de .. ó escute isso, e botou uma faixa. Ele teve a sensibilidade pra tentar entrar naquele universo, até porque era necessário para ele fazer a peça. Porque na peça uma das personagens falava de rap o tempo inteiro. É sobre uma escola de periferia uma diretora da escola, uma professora. A diretora é militante, petista, acha que vai fazer a revolução, a professora é aquela coisa de pequena burguesia que adere com facilidade ao fascismo, e dois alunos, um branco no crak e um preto que ta ali mas fala só como rap, ele quer ser rapper. Há uma rebelião na escola e o branco seqüestra os três numa sala, daí tem estupro, tem... é uma peça muito forte, muito forte, que ninguém juntaria com o Gianni, e que ele fez com uma grande sensibilidade, uma grande sensibilidade. E dizendo que ele achava que era um dos textos mais importantes que ele tinha visto nos últimos tempos porque ele não retratava uma realidade social, mas falava das linhas de força que ajudava a compreender, e que aquilo de alguma forma ia piorar, como piorou nesses dez anos.

O primeiro momento o texto, o segundo momento o ensaio, essas coisas, e o terceiro momento durante a temporada e na linha de chegada da estréia, essa coisa que desmente a idéia de que ele não tinha uma consciência da cena, uma grande preocupação com os detalhes técnicos. A iluminação dele era maravilhosa, ele era um grande iluminador, o cenário, os detalhes do figurino. Lembro dele brigando com o figurinista, era o Fabinho Namatame, brigando, dizendo, não, não é isso. E sempre a preocupação era a de harmonizar, ele usava a expressão linha de força, estar na mesma linha de força do texto do ator. Não tem que ser bonito, não tem que chamar atenção, tem que levar o olhar pra onde a gente quer que o olhar vá. É óbvio que eu peguei o Gianni já com oitenta e poucos anos, ele já não tinha o vigor do início, mas por outro lado eu acho que ganhei em outra coisa. $\mathrm{O}$ que se perdeu em vigor, se ganhou um pouco em afabilidade. Também o repertório, o folclore sobre a truculência do Gianni não é pequeno. Ele tinha uma certa impaciência com a falta de, não é a falta de empenho, mas com uma certa 
malemolência brasileira, ele não se dava bem com isso não, pra ele tinha que ser tudo meio naquele ritmo que ele imprimia nas coisas. No final da vida isso já não acontecia, ele estava mais tranqüilo.

O Sérgio Britto e a Fernanda Montenegro, falam muito do trabalho de mesa que ele fazia com o texto. Que durava uns dois meses, mas que quando levantavam a peça já estava pronta. Aconteceu o mesmo com a sua peça, ele manteve essa mesma forma de trabalho?

Vermouth não teve tanto, até porque não tinha tanto tempo. Eu não acompanhei os ensaios. Eu costumo dizer que eu sou um autor, eu sou melhor que um autor morto, que volta pra mesa branca de acordo com a necessidade, e volta da tumba no dia da estréia. Eu não acompanhei todos os ensaios. Mas sabia o que estava acontecendo, as pessoas me diziam. Não teve o mesmo tempo de mesa, até porque não havia tempo pra isso. Fazer dois meses de mesa, você tinha que ter quatro meses de ensaio. Ali ele tinha oito semanas pra pôr a peça em pé, e com dificuldade. Mas eu acho que tem uma coisa que tem a ver com o momento histórico também né? Naquela época, apesar de que hoje é exatamente igual, mas hoje em dia não se age como tal. Naquela época os diretores eram mais esses italianos, belga, os estrangeiros que vieram para cá, eles não dirigiam os atores, eles formavam os atores. Então havia uma função pedagógica que ocupava grande parte do tempo do ensaio, o ensaio era usado, em parte para você formar aquele ator. Segunda coisa era uma época que realmente o texto fazia toda a diferença, hoje em dia, há alguns diretores que trabalham nessa linha, mas são raros, e quando existem, em geral a mesa é grande, é natural. Aí eu acho que é uma mudança cultural mesmo de geração, há dificuldades até no ponto de vista educacional, quer dizer você tem uma geração hoje que não sabe a diferença entre ponto e ponto e vírgula. E isso não dá pra ensinar. Quer dizer quando chega a Fernanda, o Sérgio, o Sérgio era médico, era formado médico, Fernanda era de família suburbana, mas tinha uma cultura livresca. Então são pessoas que sabem ponto, vírgula, e ponto e vírgula, então você, dá pra você partir de um certo ponto, e hoje em dia não dá. Se você for ensinar neguinho a ler, a peça não fica de pé. Então você trabalha com o que você tem, e você não tem como fazer uma análise de texto se não tiver um mínimo de instrumental intelectual mesmo. Então aí há uma diferença que acho que é geracional.

Que é uma coisa que a gente vê pelo próprio Gianni, eu via muito isso nele. Eu não sei como era com o trabalho direto com o ator, mas a gente percebe que ele não gostava de gente burra ou gente que era....

O Gianni não tinha paciência.

É, é isso, ele não tinha paciência.

O Gianni não tinha paciência pra gente burra e pra falta de educação. E já era assim, isso não era coisa de velho. As pessoas falam isso, e ele conseguiu formar inimizades por conta disso, ele escancarava a ignorância alheia. "Olha você está falando bobagem, dá uma olhada..." Mas você trabalha com o que você tem, né?

Porque uma coisa que eu perguntei pra ele, e ele confirmou, era essa coisa de que ele tentava colocar os atores dentro do universo da peça. Então era aquela coisa de leitura de livros, de indicação de livros, do cenário, do momento da peça, então incluía o ator 
dentro disso, não era uma coisa de o figurino chegar só dois dias antes, o cenário, ele já sabia o que queria fazer.

Ele queria que as pessoas soubessem o que ia acontecer com o todo. As pessoas tinham que ter a consciência do todo do espetáculo, e a gente falou da falta de paciência dele, mas também temos que falar do contrário também. Quando ele encontrava um interlocutor, um ator, por exemplo, que ele estimulava e que ele via que acompanhava, e que ia, ele era de uma generosidade absurda. Quer dizer, ele dava livro, ele fazia, ele acompanhava, perdia tempo com a pessoa, quando ele via o interesse e o potencial. Eu lembro, por exemplo, que durante a peça ele ficou apaixonado pelo Milhem Cortaz. Ele dizia esse ator é um ator... eles brigavam pra caralho, mas ele viu o potencial, e viu que o Milhem tinha dificuldade pra entender mas ia atrás, se esforçava. Então ele, o Gianni, despendia o tempo que fosse necessário pra fazer com que o Milhem entendesse e incorporasse o máximo possível daquilo. Em compensação com outros atores, depois de poucos ensaios ele já “... é burra, não entende, uma vaca, é uma vaca, não vai entender nunca”. É compreensível, quer dizer aqueles para com quem ele tinha simpatia, e ele tinha essa generosidade, vão adorar ele sempre. As pessoas com quem ele tinha essa outra reação vão sempre falar mal dele. Não tem como. Agora ele não é, ele mesmo dizia de si mesmo, que ele não estava inventando a roda, ele estava fazendo era continuar uma tradição, uma tradição que essa, não quer dizer que os outros teatros sejam melhores ou piores que esse, mas o teatro que eu faço é esse. Isso é uma tradição e eu tô seguindo. A outra coisa que ele me falou várias vezes, é que a verdadeira escola de teatro que ele teve foi o Scala. Foi o tempo que ele sentava no escuro da platéia pra ver o maestro trabalhar com os músicos, ou com os cantores. Que é mais aproximado dos atores também. Esse trabalho de destrinchar a partitura, dar uma corporeidade a esse som, e conseguir fazer isso por meio de seres humanos, quer dizer como estimular, ou disciplinar esses músicos, esses cantores, foi que lhe deu os instrumentos para dirigir teatro mais tarde. A gente tem que lembrar que ele nunca dirigiu teatro em italiano, ele sempre dirigiu teatro numa língua que era a segunda língua dele, que era o português. Ele evitava falar em italiano. Ele tinha lá o grupo dos lígures dele, da Ligúria, aí eles falavam entre si. Mas, por exemplo, ele ficava muito irritado com gente, brasileiro, que vinha falar em italiano com ele. Ele odiava. Tinha uma menina que morou na Itália muito tempo, e estava aqui em casa, num aniversário meu, e ela começou a falar em italiano com ele, ele foi se irritando, se irritando, e ele disse "ó filha, português, português, italiano você fala lá fora".

Eu acho que quando ele se transportou, o português pra ele era uma ferramenta de trabalho. O Gianni, até três meses antes de ele morrer, pra ele, ele estava trabalhando. Tinha projeto pra fazer cenário, figurino, luz, e tava escrevendo. Quer dizer, maior apropriação da língua não há, ele escrevia em português e escrevia bem. Mas a gente tem que lembrar que se o aprendizado dele como diretor foi acompanhando música, se a relação dele com o texto e com o ator, a língua é um elemento fundamental, pois esse homem conseguiu construir uma obra como encenador, com esses elementos, numa língua que não era a dele, que não era nem a segunda língua dele né, porque ele já falava francês e, inglês ele tinha problema, ele não tinha muito saco pra inglês, se precisava ele falava, mas a segunda língua dele era francês. Italiano, francês, entendia espanhol, então é um cara que aos trinta e muitos anos, escutou essa língua em desuso que é o português, e escolheu essa língua como instrumento para o que seria a carreira desse homem, então há um descompasso aí, né? Há um descompasso que faz com que, por exemplo, você se atenha muito mais ao texto, num primeiro momento. Como é que você vai improvisar numa língua que você... Tô pensando quando ele chegou, nas 
primeiras direções, ele conhecia o texto profundamente, L'Allouette (O Canto da Cotovia"), do Anouilh, era um texto que ele já conhecia profundamente. "Ralé", do Gorki, que ele já havia feito o cenário para o Piccolo, também era um texto que ele conhecia profundamente, e que depois montou aqui, mas textos falados numa língua que era nova pra ele. Então esse é um outro motivo que leva ele a ficar muito grudado no texto. Se ele começar a brincar, a possibilidade dele errar não era remota.

E uma coisa que a gente vê, no trabalho do texto, numa língua que ele não conhecia e que acabou ganhando todos os prêmios com a montagem de "O Canto da Cotovia", quando chegou no Brasil.

Não, mais do que isso. Ao longo da trajetória dele, ele pega essa língua que não é a língua dele e é um dos responsáveis pelo fato dessa língua ter uma dramaturgia forte. Se não fosse ele, repito, Jorge Andrade, Arthur Azevedo, Vianninha, Chico Buarque, Guarnieri, quer dizer o cara, e em momentos importantes, não é só que ele montou, montar todo mundo montou, ele fez com que tivesse uma visibilidade que não tinha antes.

De valorização de cunho nacional, né?

De valorização, de respeito, ele angariava, ele construía respeito pra uma dramaturgia que nós brasileiros não respeitávamos.

E dentro disso que você está falando, me lembrei de uma coisa, eu percebo, nas poucas vezes que conversei com ele, da valorização da composição da personagem. E a gente vê muito claramente isso, e eu queria que você me dissesse como foi no Vermouth, por isso que estou lhe perguntando, numa gravação do "Mambembe" de 1959, não sei se você ouviu falar dela, e que eu ganhei de presente.

Nunca ouvi, mas já me falaram.

É um jogo de fitas cassete que pretendo passar pra CD, e se você quiser depois lhe dou uma cópia.

Por favor!! Que bárbaro!!

Então é muito interessante, ouvindo a peça, o trabalho de composição dos atores. A Fernanda, por exemplo, usa uma voz composta especialmente para a personagem da "ingênua" do Mambembe.

Pra isso você precisaria falar com os atores. Isso eu não saberia te dizer. Eu sugiro que você fale com o Milhem Cortaz, ele vai saber te dizer isso. Pra formação dele como ator foi muito importante.

E quanto às montagens. Ele me disse uma vez que hoje em dia tinha muita porcaria..

É, o que ele não gostava era da pirotecnia, o que ele não gostava era da cena que ficasse maior do que o ator e o texto. E como eu ele não gostava também dessa coisa masturbatória de ficar fazendo livre associação no palco. Agora também você tem que ver que todos nós, ao longo dos anos, vamos achando tudo vai ficando uma merda. Um 
pouco isso também, você vai ficando sem paciência, as costas doem. A não ser que seja uma coisa excepcional a gente vai perdendo a sensibilidade pro médio, e perdendo a necessidade para o que está nascendo. Até porque a sensação de urgência é muito grande, e você só se deixa arrebatar por aquilo que é excepcional, e aí você perde generosidade. Aos seus oitenta é mais do que nós aos trinta ou quarenta. De qualquer forma a tendência é mais ou menos essa. Então eu sempre dou um desconto, quando eu vou, eu dou um desconto porque são as minhas costas, é teatro demais que eu já vi, é isso. Agora, ele tinha esse olhar para o novo, mas é óbvio que era um novo parecido com ele.

Dentro do que você falou, você não acha, contradizendo um pouco o que você disse, você não acha que também pela experiência, ele não tem como analisar, mesmo que ele não goste, como você está falando, mas de analisar, apesar da idade e tal, aquela ponta de coisa, olha é muito ruim tudo, mas tem algo de novo, de...

Pode, pode. Agora que novo, esse é o ponto. Décio de Almeida Prado quando largou a crítica em 1968, largou por causa do episódio do Saci. Mas logo em seguida ele disse: "eu larguei no tempo certo, quando vi "Gracias Senhores", em 69, ou 70, não me lembro bem. " Eu saí no tempo certo, porque essa manifestação eu não tenho instrumentos pra falar sobre ela. De certa forma acho que esse teatro que o Gianni passou pra frente é absolutamente vivo e necessário, mas é quase outra arte se você comparar com a encenação pós-moderna. Se você pensar em teatro físico por exemplo, é outra linguagem, alguns elementos são comuns mas o teatro acaba virando uma palavra ônibus, onde cabe uma série de coisas que não necessariamente conseguem dialogar entre si. E é nesse sentido um homem formado nessa tradição pode não ter olho pro novo numa linguagem que não seja a sua específica, e aí não tem a ver com o ser velho, ou não, tem a ver com algo específico. Até porque ele sempre trabalhou com gente jovem.

O novo que eu digo, é no caso por exemplo que você citou como o do Milhem, dele ver numa coisa absurda que exista mas que tenha um ponto de....

Sim, por exemplo, o texto sobre a internet que foi dirigido pela Débora Dubois. Era um texto para adolescentes. Ele foi ver porque gostava de mim. Ele jamais iria ver, e ele era duro com as minhas coisas. Quando não gostava das minhas coisas ele dizia, aliás o meu pior algoz era o Gianni. Eu mandava tudo que eu escrevia para ele. Umas coisas ele gostava, outras coisas não gostava. Ele sempre dizia isso: falta trabalho. Você faz coisas demais. Você fica fazendo curadoria, direção, não sei o quê, que sofre é a sua dramaturgia. Tua dramaturgia é mais rasa que você. Você tem mais capacidade do que aquilo que você escreve. Ele sempre me dizia isso. Ele era muito crítico com a minha atitude perante a carreira. $\mathrm{Na}$ verdade não perante a carreira mas perante ao ofício. Ele dizia: não dá pra você ser sapateiro e bater sapato de vez em quando. Ele dizia: você tem um compromisso com o seu ofício. Que era o que ele cobrava de todo mundo.

Por último, eu gostaria que você falasse da importância que você vê do Gianni para o teatro brasileiro.

Primeiro isso, sem o Gianni, eu acho, de verdade, que o panorama da dramaturgia brasileira seria outro. Sem o Gianni o Jorge Andrade não teria começado tão cedo, sem o Gianni, Arthur Azevedo ainda ia ser tratado como uma cariocada. Sem o Gianni, 
talvez não aconteceria o que acontece hoje, que você pega o jornal e mais de cinqüenta por cento das encenações são de textos nacionais. Óbvio que não foi só o Gianni quem fez isso, mas acho que o Gianni é um dos artífices da dramaturgia. Pro teatro ele fez parte de um coletivo que fez com que a gente entrasse para a modernidade. Não foi só ele, mas ele fez com que a gente entrasse na modernidade. E desse coletivo ele, e talvez o Vaneau, mas muito mais em função da relação do Vaneau com a dança do que com o teatro propriamente dito. Foi, dessa geração, o que veio pra cá, ao invés, o que se incorporou a produção e não, simplesmente, teve um papel pedagógico. Então nesse sentido ele talvez seja o mais importante dessa geração, pra mim. Porque ele não simplesmente deu um estarte e foi embora, ele não simplesmente trouxe um conhecimento. Ele construiu uma cena. Ele não reproduziu uma cena, ele construiu uma cena brasileira. Então é um dos artífices do teatro moderno brasileiro. O teatro moderno brasileiro teria uma outra cara se o Gianni não estivesse. Em terceiro lugar tem uma série de pessoas insuspeitadas em que você jamais acharia que tem a marca dele. Vamos falar de pessoas de São Paulo, não vamos nem falar do Rio de Janeiro.

Celso Frateschi e Roberto Lage por exemplo, talvez fossem pessoas cuja obra você não aproximaria da obra do Gianni. Eu sou filho do exemplo. Meu trabalho tem antes e depois de ter feitoVermouth, não só no sentido ético, mas no sentido prático mesmo. Aprendi mais em dramaturgia naquelas duas semanas mexendo no Vermouth com ele, do que na minha vida inteira. Bosco Brasil e Ariela Goldman. Quer dizer, dá pra dizer com tranqüilidade que uma obra prima do teatro brasileiro nos últimos dez anos é "Novas Diretrizes nos Tempos de Paz". Nessa obra prima você tem um texto que parece esplendoroso, um texto que vai ficar, um cânone. Eu me emociono de me lembrar dele. Que tinha uma encenação extremamente inteligente da Ariela, tinha o cenário e a luz do Gianni, tinha os atores, o Dan que estava num momento inspirado, todos os outros atores que passaram pelo outro papel, o Jairo, o Paschoal, o Toni Ramos, todos os elementos eram maravilhosos. Só que se você pensar nesses elementos, esse era um espetáculo do Gianni Ratto. Ele é uma súmula das opções do Gianni. Pelo amor de Deus eu não to dizendo que, pelo amor de Deus... Poderia inclusive não ser cenário e figurino do Gianni, não estou dizendo que o cenário... pelo amor de Deus, não é isso. Mas a direção da Ariela poderia ser uma direção do Gianni. O texto do Bosco segue todas as opções estéticas e éticas do Gianni. Então esse espetáculo, que é o melhor que a gente fez nos últimos dez anos, é um espetáculo do Gianni Ratto, ainda que ele não esteja ali. Até está, quer dizer por que foi o ano que ele ganhou um Shell especial. Ele foi reconhecido como cenógrafo e iluminador disso. Mas a importância não é essa, a importância maior é que os valores do Gianni estavam ali. Aquilo que, repito, é o melhor que a gente fez nos últimos dez anos é um espetáculo de Gianni Ratto. E de uma brasilidade desesperada, em busca de uma identidade.

Os depoimentos que colhi com outras pessoas são unânimes em considerar o Gianni não apenas como um diretor, mas muito mais como um professor, um formador de atores para que eles possam caminhar com os próprios pés, aprendendo como desenvolver o seu trabalho. Diferentemente de diretores como Celi, Ruggero Jacobbi, D'Aversa, Ziembinski, Gianni dava liberdade para a criação da personagem pelo ator.

Tanto que você vê que a companhia Teatro dos Sete, diferentemente das outras companhias Tonia, Celi, Autran, Nidia Lycia e Sérgio Cardoso, entre outras, é o que tem de mais próximo do que viriam ser o teatro dos anos 60: Oficina, Arena. A única dessas companhias que se aproxima até sobre o ponto de vista de organização de um grupo é o Teatro dos Sete, e com certeza vem do espírito do Gianni. E a experiência 
marcante da vida dele é o Teatro Novo, que era um projeto mais pedagógico que estético na verdade, que era inerente ao trabalho dele. 


\section{Entrevista com Maria Della Costa}

$19 / 01 / 2007$.

Cheguei em Paraty no dia 18 de janeiro de 2007, às 16:00h aproximadamente. O tempo estava abafado e havia um chuvisco fraco. Conforme o e-mail que havia recebido do Hotel Coxixo, de propriedade da Maria, e onde ficaria hospedado, bastava sair da rodoviária e andar uns quatro quarteirões até a Rua do Comércio, onde ele está situado.

Peguei a indicação novamente com a caixa da bilheteria da rodoviária, onde estava comprando a passagem de volta para o dia seguinte, 19 de janeiro, às $11 \mathrm{~h} 40 \mathrm{~min}$. Encontrei o hotel, mas era os fundos dele, e um funcionário logo me identificou, pois era o Luciano, aquele que havia passado o e-mail com as instruções. Ele já estava de saída, mas fez questão em me acompanhar para registro e depois me levar até a Maria, que já havia perguntado se eu havia chegado. A casa dela fica nos fundos do hotel, por onde eu havia entrado, e logo fui recebido por ela e seus gatos (dois siameses) que passeavam por toda a casa. Ela, muito elegante, nos seus não aparentes 81 anos de idade, me recebeu afetuosamente. Uma mulher muito bonita e que, com certeza, na sua juventude deveria ter balançado muitos corações. Não se trata apenas de uma beleza exterior mas, acredito, o reflexo de seu interior que a faz tão luminosa e cativante. Ela também estava cansada e preocupada com uns problemas do hotel, além de ter que conferir uma correspondência e umas encomendas que seu gerente, Gilberto, havia trazido de São Paulo.

Marcamos para que ela me recebesse no dia seguinte pela manhã, por volta das 8:00h, uma vez que, como ela mesmo disse, acordava muito cedo, aproximadamente às 6:00. Sugeriu-me que tomasse um banho e fosse conhecer a cidade, sugestão essa que acatei com prazer.

Eu queria que primeiro, você falasse um pouco de como surgiu a idéia de você criar um teatro, a idéia de criar uma companhia.

Bom, acho que qualquer atriz gostaria de ter a sua própria companhia, e depois eu era casada com um produtor, que era o maior produtor da época, que era o Sandro Polloni, produtor e empresário de teatro, e sobrinho da grande Itália Fausta. Então, era um homem que nasceu dentro do teatro, amava o teatro de uma maneira incrível. Então a gente se casou e a gente sempre quis ter a nossa própria companhia, a gente formou a nossa própria companhia que fundiu Os Comediantes, que você sabe Os Comediantes eram do Rio de Janeiro, que foi aquela renovação que houve no teatro moderno, então o Sandro fazia parte, com Miroel Silveira que era o diretor dos Comediantes. Aí o Miroel ficou doente e fundiu Os Comediantes que passou a se chamar Teatro Popular de Arte, com o meu marido sendo o empresário e o dono, e o Miroel sempre colaborando conosco. Depois o Miroel morreu e a companhia ficou totalmente nossa juntamente com a Itália Fausta, tia do Sandro, e fizemos muitas peças no Rio de Janeiro, grandes peças grandes, aqui a gente já iria entrar para um outro campo de batalha, pra te contar toda a história, mas isso é outra coisa. Aí surgiu o problema da casa de espetáculos, porque você sabe há falta de casas de espetáculos no Brasil. Tanto é que eu nunca vou, nunca ia quase ao Rio de Janeiro por falta de espetáculos, por falta de casa de espetáculos. Então praticamente eu passei a ir muito pouco para o Rio de Janeiro. Onde é que eu ia? Ia no Teatro Municipal, eu ficava assim oito dias, dez dias, não podia ficar mais, e voltava pra São Paulo. Surgiu o problema do teatro, como eu te falei. Então a gente conseguiu, como o Sandro era paulista, ter mais facilidade de construir e de encontrar um teatro em São Paulo. Então, o Teatro Maria Della Costa foi construído para teatro mesmo, que 
foi o diretor, o dono da Folha, o Otávio Frias, que era diretor do Banco Nacional, da Bolsa Predial do Banco Nacional do Banco Roxo Loureiro. Então ele acreditou em dois jovens, nós éramos dois jovens, e ele conseguiu um terreno na Rua Nove de Julho, na Rua Paim, e nós construímos o teatro que levou... nós levamos quinze anos pagando o teatro para o Otávio Frias. Depois mais três anos o ar-condicionado. Aí o teatro ficou pronto com a ajuda do Getúlio Vargas, o Getúlio nos ajudou nas cadeiras, que faltavam as poltronas, mas não conseguiu dar todo o dinheiro porque naquele mês ele morreu, $o$ Getúlio. Foi, não me lembro a data, e aí ficou assim o Ministro da Cultura me chamou e disse "Olha eu vou dar pra vocês o mínimo, mas tenho que dar alguma coisa pra vocês. Aí deu e a gente deu a entrada para as poltronas. Bom, o teatro estava quase pronto, praticamente vestido, bom, e agora qual peça? Qual diretor? Como no Brasil também faltava diretores, né? E tava a onda dos diretores italianos virem pra cá, porque é praticamente a nossa mesma língua, latinos né? Tem o nosso mesmo temperamento. Aí a gente começou a pensar nos italianos, peça a gente também estava escolhendo. Porque naquela época os intelectuais liam as peças, tradutores, tinham vários tradutores, escritores, jornalistas que iam para os Estados Unidos e que liam muito, e mesmo peças nacionais e vinham oferecer para as companhias e a gente lia, lia daqui, lia dali, aí eles falaram do Gianni Ratto. Não, falaram do Piccolo Teatro de Milão, que o Piccolo Teatro era conceituado assim um dos melhores teatros do mundo! Como diretor, era um núcleo que tinha de atores, de obras, de teatro, de tudo, de encenação. E aí a gente partiu pra Milão. E conversando lá, diz olha tem um diretor, um cenógrafo, que gostaria de conversar com vocês, que ouviu a nossa conversa aqui e gostaria de conversar, eu acho que ele até iria para o Brasil. Aí apareceu o Gianni Ratto. O Gianni era considerado um dos maiores cenógrafos do mundo! Aí ele veio conversar conosco, muito simpático, magrinho!! Ele tinha feito até, parece, a cenografia do Sartre.

\section{Entre Quatro Paredes?}

Entre Quatro Paredes. Aí ele disse assim Ah, o Brasil! Aí ele gostou muito do Sandro porque o Sandro era um homem muito arrojado e ele viu logo que nós éramos duas pessoas honestas. A gente levou fotografia de tudo. E ele disse, olha eu gostaria de sair um pouco da Itália e conhecer o Brasil. Porque sempre ouviu falar muito no Brasil. E ele ficou muito entusiasmado, e ele disse, olha eu vou dar a resposta. E aí a gente falou com ele também sobre a peça. Eu digo nós não temos uma peça pra inaugurar o teatro. Ele disse ó eu vou procurar. E no dia seguinte, ou dois dias depois, ele disse, olha eu vou pro Brasil. Ficou muito entusiasmado e a gente ficou apalavreado com ele. Ele disse eu vou, vamos nos escrever, e tal, e vou procurar a peça. E depois a gente recebeu a notícia que ele tinha uma peça e que viria ao Brasil. Aí eu disse assim, agora o dinheiro pra passagem! Porque nós estávamos... a gente não tinha dinheiro pra nada! Eram dois jovens assim querendo o mundo, abraçar o mundo mas com os pés no chão, evidentemente! E como que a gente vai trazer o Gianni Ratto? Aí o Sandro tinha um carro, vendeu o carro, né? Pra comprar as passagens e mandou o Gianni Ratto vir. E agora pra morar?

\section{Nossa!}

Vai morar onde. Um grande cenógrafo. Você sabe que todos os italianos são assim, todos requintados, na sua vida em Roma, em Milão... De Milão para.... Onde é que ele vai se hospedar, no hotel? Mas que hotel, nós podemos pagar hotel? Nós tínhamos uma casinha em Tremembé, no fim da linha de Tremembé, muito, muito pequenininha, tinha 
um quarto... três quartos, junto com a minha sogra. Uma casinha muito simplesinha com uma subida pro carro, entende, e só isso, numa esquina de Tremembé, da rua. E aí a gente disse, bom, vamos esperar o Gianni Ratto (ela ri).

E ele vinha com a mulher também, né?

Não ele veio sozinho, ele veio sozinho. Aí desembarcou o Gianni Ratto , aí a gente, como é que a gente vai explicar pro Gianni Ratto que um hotel da categoria dele não tem. Ratto, olha você vai morar conosco, mas olha a casinha, é uma casinha de pobre. "Não tem problema, não sei o que..." ele com a malinha dele. E a gente pegou o carro emprestado do irmão do Sandro e tocamos lá pra Tremembé. E no terminal lá ele dizia, ai que lindo, que lindo, que maravilha. Ele estava todo entusiasmado, país novo, né? Mas acho que por dentro ele dizia, onde é que eu vou parar? (risos novamente). Aí entramos s na nossa casa, ele olhou e disse assim: É, simpático, né? Aí eu apresentei a minha sogra que era um amor, uma milanesa maravilhosa! Cozinhava que era uma beleza. Recebeu ele com muito carinho, ele já abraçou a minha sogra, beijou a minha sogra, "italiani, tutti italiani". Eu filha de italianos de Veneza, a minha sogra milanesa, ele eu acho que era

Ele era milanês, era de Milão.

Ele era milanês também. E aí ficou tudo em casa. Minha sogra fez o almoço pra ele, depois ele foi descansar, botou, pendurou a roupa dele. E ficou tudo bem. E nós todos aflitos, a casa muito simples realmente. Mas ele estava felicíssimo, coisa nova. Aí ele ficou na minha casa, e trouxe a peça. Trouxe a Joana D'Arc com ele, embaixo dos braços. L'Alouette, que é a Joana do Anouilh. Ele disse, olha vocês lêem

\section{Você não conhecia ainda?}

Não, a peça não. Conhecia a história. Tinham vários livros, várias peças sobre a Joana D'Arc. Aí o Sandro pensou, ih, Joana D'Arc, sabe, eu não pensei numa coisa dramática para a inauguração do teatro, mas vamos ver o que que é. Aí ele leu a peça, foi traduzida, e a gente ficou deslumbrado com a peça. Uma peça moderna, linda né? E ele disse, eu vi a figura da Maria - depois que ele me falou - eu vi a figura da Maria, e na conversa da Maria, no olhar da Maria, e na candura - ele gostava muito de mim - na candura da Maria, no rosto da Maria, eu tinha certeza, e tenho certeza que ela vai fazer uma grande Joana. Bom, aí foi tudo alegria, sacrifício, trazer o Gianni pra são Paulo, porque era uma viagem, não é? Aí o irmão do Sandro...o Sandro comprou o carro velho do irmão dele e foi pagando aos pouquinhos, e ficou então com o carro. Levava o Gianni Ratto, e voltava, e a comida às vezes, ele tinha que voltar, não voltava, às vezes a gente levava em restaurante, ou levava na casa de amigos pra ele comer. Mas ele tava sabendo que eram jovens que estavam querendo se formar e fazer uma coisa de categoria, e de bom gosto, e de renovação no Brasil., né? Então ele percebeu que era uma coisa nova, e isso ele gostou. Ele gostou da nossa honestidade, da nossa juventude, da nossa luta e do nosso poder de conquista, de querer ir pra frente. Porque o brasileiro é muito intuitivo também, o brasileiro quando quer, quer. Então ele ficou amando o Brasil já de cara, assim, ficou apaixonado. Então a gente começou a escolher o elenco, a escolher esse, aqui, aquele, Eugênio Kusnet, você deve ter a lista dos atores. 
Tenho sim.

Mas, começaram os ensaios, e aí começou uma pequena guerra. Dos atores e do Gianni, do Eugênio Kusnet, que era diretor também, e que também era professor disse assim, Como?, eu estou aqui no Brasil, sou grande professor, e diretor, e eles vão e contratam um diretor que não fala uma palavra de português. Como é que ele vai ensinar os nossos atores? Aí começou aquele ciúme. Aí ele começou introduzir, o Eugênio Kusnet, aquele ciúme, aquela mágoa, aquele negócio todo nos outros atores. Porque os atores ficavam nervosos porque não entendiam o Gianni Ratto falava muito, entende? Era mais na mímica, porque ele estava ainda aprendendo o português também, ele tinha muita força de vontade, o Gianni. Aí começou uma guerra, sabe, surda, muda, e aí começou a se espalhar e começou, o Gianni Ratto começou a se sentir mal. Começou a se sentir mal e não conseguia dirigir, muito emotivo que ele era. Aí ele chamou o Sandro e eu num canto e começou a chorar. Eu pela primeira vez vi um homem daquele jeito chorando desse jeito. Ele disse, olha estou realmente chorando porque eu quero trabalhar, eu vim com esse propósito, vocês me chamaram pra eu criar uma coisa nova e eu estou tentando, mas eu to sentindo que a barra ta pesada pra mim aqui, eu não posso dirigir assim, nessas condições. E eu disse, não, eu vou, eu como mulher, e como dona da companhia, e como amiga dos meus atores, porque eu nunca fui patroa. Aí eu comecei a chamar um por um e disse olha o nosso propósito é esse. Chamei Eugênio Kusnet. Eugênio você terá outras direções também, você vai ajudar em outras coisas, mas aqui nós temos que inaugurar o teatro com uma coisa nova. É um diretor que vem de fora, da Itália, grandes promoções nos jornais, nos livros, e tudo. Ele foi se acalmando, se acalmando, o elenco também foi se acalmando, e a gente entrou num ritmo de trabalho maravilhoso, e de criatividade, de criação. O teatro estava terminando, pintaram, eu peguei no pincel também. A gente foi uma guerra pra terminar o teatro. Acabamos, inauguramos, você sabe que foi construído pelo Niemeyer né? Niemeyer e Lúcio Costa. E aí fizemos uma lista de convidados, governador, ministros. E aí fizemos uma estréia que foi a coisa mais linda que foi... Porque o Gianni, foi o que a crítica falou, o Gianni Ratto como diretor, eles não tinham muita visão do Gianni como diretor, como cenógrafo. Então todos eles pensavam: bom, ele vai se esbaldar no cenário, ele é cenógrafo então ele vai querer aparecer porque geralmente é assim. Os cenógrafos fazem a criatividade, eles querem aparecer, é justo, tão ali pra fazer. E ele então, a crítica toda espera a abertura do pano pra ver. E quando abriu o velário, o velário, o pano de boca, foi aquela coisa maravilhosa de cenário. Que era de uma simplicidade! Você viu as fotografias ali (no museu do Hotel), tem ele simples, sem iluminação, e no final quando acendiam as luzes atrás dos vitrais, que formava aquele colorido todo dos vitrais, era uma catedral, uma igreja mesmo. O público levantava e aplaudia aquilo, porque era uma coisa linda. Ele fez aquilo com papel celofane por de trás, as cores, recortado tudo. Foi então, o cenário foi de uma sobriedade que deu lugar ao texto, o texto sobressaiu. Não é aquelas coisas que o cenógrafo faz e mata o texto. Como dizia Itália Fausta, $\mathrm{Na}$ minha época a gente até fazia teatro com uma rotunda, porque a palavra estava em primeiro lugar, o autor. Depois veio a evolução. Mas o Gianni Ratto cuidou muito disso e fez o cenário e a crítica falou... O Décio de Almeida Prado colocou o espetáculo nas alturas, todos, todos, todos, toda a crítica, né?

Uma coisa que diferencia o Gianni, que eu vejo, é que ele privilegiava o autor e o texto, não é?

Claro!! Ele era diretor tanto do texto quanto dos atores. Apesar de falar italiano, mas ele aprendeu rapidamente, entende. Ele pegou o ouvido bem do nosso idioma e era um 
grande..., porque ele tinha uma prática. Ele não dirigiu muito lá em Milão, mas sabe que a prática né? A prática comanda, porque a teoria é uma coisa, você pode ler um texto maravilhoso, vem um diretor e diz: Olha Maria aqui está o texto pra... porque eu não faço leituras? Me convidam, eu não sei fazer, eu não consigo ler. Então vem o diretor, senta na mesa, fica explanando o que é uma peça, o que é o texto, o que é a personagem, as personagens, ele lê no primeiro dia. No segundo dia ele manda a gente ler só com pontuação, sem inflexão, pra entender o que você está lendo. E eu lia muito mal. Mas eu lia muito mal. Eu já prevenia os meus atores, os meus colegas, e ele, eu dizia, olha eu leio muito mal porque sou muito nervosa, muito emotiva. Eu gaguejava, eu não enxergava a pontuação, aí os diretores ficavam assim comigo, entende? Mas eu ia pegando, cada dia eu ia melhorando. Porque tinha atores que liam e já formavam o personagem no primeiro dia. O diretor explicava, no segundo dia da leitura o cara vinha, o ator, a gente se olhava e dizia, bom esse aqui já construiu o personagem, já nos matou todos aqui, a gente vai ter que suar aqui pra construir nosso personagem. Mas parava naquilo, não evoluía. E a gente sabe, eu ia evoluindo, evoluindo, evoluindo. Teve um Feydeau, eu adoro Feydeau, porque na nossa companhia era assim: uma grande peça, vamos dizer um Canto da Cotovia, uma Joana D'Arc, e depois uma comédia pra aliviar, Porque não era como nos dias de hoje, que é uma hora de espetáculo, essas peças que vem, e sextas, sábados e domingos. Três dias. Nós lá não, era segunda, que depois foi abolido, terça, quarta, quinta duas sessões, que era de tarde para as senhoras, as matinês como se chamavam, e à noite, sexta, sábado, duas sessões, e domingo duas sessões. E eram espetáculos de texto, eram duas horas ali batidas, e depois tinha outra sessão. Então era uma época em que a gente fazia um teatro suado, de trabalho mesmo, de exaustão. Mas era uma coisa maravilhosa entende? Eu peguei essa coisa e...

Você estava falando de Feydeau...

Pois é. Então como era muito cansativo, a gente montava uma grande peça. A Alma boa de Set suan, por exemplo, Bertoldt Brecht né?, eu fazia um homem e uma mulher, era um espetáculo muito cansativo, principalmente para mim, as mudanças tudo.. Então a gente sempre colocava uma peça de bom nível mais uma comédia, aí os críticos não gostavam muito, "Feydeau, uma chanchadinha!" Porque Feydeau, na sua essência, era um grande autor. Eu levei umas três peças dele, eu amo Feydeau, que é muito difícil fazer Feydeau. Precisa de muitos bons atores. Porque é um pique, um timing certo que tem a comédia dele. Então eu levava sempre uma peça leve pra contrabalançar com as peças mais pesadas.

E havia assim uma diferença, por exemplo, como você falou... Ele dirigiu a Pulga Atrás da Orelha com você. Havia uma diferença, da forma dele dirigir por exemplo O Canto da Cotovia e a Pulga? Como era o processo da direção? Vocês ensaiavam todos os dias? Quantas horas?

Era outra coisa. Nós ensaiávamos das duas da tarde às oito, nove. Não tinha horário pra acabar. A gente comia até sanduíche dentro do teatro, e tocava até uma hora, duas horas da manhã. Eu não conseguia pegar o ritmo da Pulga Atrás da Orelha, acho que foi com a Fernanda Montenegro a peça, né?

É foi com a Fernanda. 
Eu não pegava o ritmo de Com a Pulga Atrás da Orelha. Aquele ritmo que ele queria. Ele estava na última fila e eu chorava e dizia Gianni eu não consigo fazer aquilo que você quer. Aquele ritmo leve, entende? De abrir porta, sair, mudança de roupa... Faltava quinze dias e eu ainda não tinha pego o ritmo da minha personagem. Todo mundo já tinha pego, a Fernanda, todo mundo, todo mundo. E eu não conseguia.. Acho que era nervosismo, entende, porque ele era um diretor..os italianos eram muito austeros, entende, no trabalho. A gente estava habituado mais com os brasileiros, que não eram grandes diretores, era tudo jovens, né. Mas, ele já vinha com uma bagagem de uma escola, de direção. E ele me chamava de lado e dizia, Maria você ainda não pegou isso aí. Eu dizia, eu sei Gianni Ratto, não peguei, não peguei, não peguei. Quando faltavam usn oito dias pra entrar a peça, ele estava nervoso - ele estava na última cadeira lá em cima - eu entrei em cena e fui, deslanchei. Ele levantou e eu também levantei os braços, os dois ao mesmo tempo e ele disse, Pegou! E eu, Peguei! E aí foi, uma maravilha. Mas, isso é construção da personagem, entende? Isso eu acho uma maravilha. A gente não é gênio, eu nunca fui gênio no teatro. Eu fui uma mulher sempre que estudei muito as minhas personagens, mas também muito intuitiva. Porque o Décio é que dizia isso que eu fazia as personagens de terra, da terra, muito bem! Que eu era maravilhosa. Porque eu sempre abria o velário, o pano da minha companhia, o público nunca sabia o que é que eu ia levar, como é que eu ia aparecer. Então eu fazia prostituta, eu fazia santa, eu fazia negra, sempre né? Brecht, um homem e uma mulher, eu fazia Garcia Lorca. O Garcia Lorca eu fiz com cinqüenta anos, a Bodas de Sangue com o Antunes. E ele começou ali com o Garcia Lorca, e o Décio disse, ela parece uma menina de quinze. Então você vê que eu sempre tive muito trabalho e gostava muito. Mas o Gianni, voltando ao Gianni, ele era um diretor que tanto fazia o drama, teatro, porque ele era um cara, assim, versátil. Ele era um... era um gênio, pra mim ele era um gênio. Aí ele começou a se apaixonar pelo Brasil. Veio a mulher dele. Ele era muito mulherengo, também. Ele adorava as mulheres, né? Lembro que uma vez a gente estava ensaiando, ele tinha um cenário baixo, não me lembro qual era a peça, ele era muito magro, e muito ágil, e ele foi se mostrar pra menina, ah você faz assim, dá esse pulo assim, bate em cima assim, ele bateu com a cabeça, o centro da cabeça numa viga, e caiu desmaiado. Ele queria se mostrar pra menina. (risos). Mas ele era um ser humano fantástico, viu? Fantástico.

\section{Ele dava algum exercício pra vocês fazerem, durante os ensaios?}

Não. O exercício pra ele era repetição. Era o timing. Repete, repete, repete. Descansa. Toma á gua, toma um café. Agora começa de novo. Senta um pouco. Raciocina o que você está fazendo. Leia. Pega a peça pra mim, de novo, e leia o texto, desse texto que você está fazendo. Aí ele descia e dizia assim, vai Maria, ou um outro ator qualquer, e a gente fazia com ele a repetição, mas não feito papagaio. Era entender o que se estava lendo. Porque às vezes o nervosismo de querer fazer na prática...mas a teoria é uma coisa importante também, de você também entender, né? É aquilo que eu falei, o ator vai e faz mas depois fica naquilo. E ele tinha esse tipo de exercício, de leitura. Muita leitura, muito entendimento. Ele dizia, Maria o que que você acha que é essa personagem, como é que você vê - no início dos trabalhos na mesa. Ele lia, depois a gente lia, e ele dizia, como é que você vê essa personagem? Né? Ele deixava você explanar dentro da sua maneira de ser. Porque ele não impunha, ele não dizia assim, não era um tipo Ziembinsky. O Ziembinsky era um grande diretor, mas ele dava tudo, inclusive as marcações, as inflexões dele e quando você levava, ia ver no palco, era um pouco Ziembinsky todo mundo, né? Ele não, ele dizia assim, Não, porque ela pode 
levar a personagem aqui, ali, e acolá, entende como é? Ele não deixava você: Não eu quero assim!! Não tirando a linha da personagem ele deixava

\section{A liberdade...}

Exatamente, pra você fazer a sua personagem. Criar dentro daquilo que ele queria. Porque o espetáculo, é uma criação, é uma linha da peça que ele dava. Como Feydeau, e você não podia fazer uma coisa que não era dentro daquela linha de leveza, né? O Canto da Cotovia. Era aquela personagem maravilhosa, guerreira, e ao mesmo tempo santa, ou ingênua, pura, então você tinha que dar todas essas nuances. Então você tinha que procurar. Mas procurar como? Na infância, aí o que quer dizer isso, o que não quer dizer aquilo. Eu era muito jovem também né? Tava iniciando. Então era um trabalho de criação, uma coisa muito gostosa. Mas isso era o Gianni Ratto, aí o Gianni depois, veio a mulher, ele alugou acho que um apartamento. Começamos a fazer outras peças, depois eu tive outros diretores italianos também, cenógrafos, e aí veio um problema de... de ciumeira, né? Ele começou... Eu falei outro dia sobre isso. Eu nunca toquei nesse assunto, mas eu acho que o Gianni Ratto....Foi como eu te disse, ele era muito apaixonado, e tal... E ele teve uma paixão por mim também., mas eu era muito bem casada com o Sandro né? E a Fernanda estava na minha companhia. Então eu achei por bem, e isso ninguém soube disso também. Eu disse, olha Sandro eu quero fazer a operação da garganta, e vou aproveitar e você faz o Jorge de Andrade (A Moratória) com a Fernanda Montenegro, com o Gianni Ratto. Porque eu não podia, eu queria ver se o Gianni esfriava. Porque era uma coisa que já estava me incomodando já , aquela coisa dele, aquela atração dele por mim. Eu sei que aí houve um problema, o Gianni Ratto chegou pro Sandro e disse, Olha Sandro eu queria carta branca pra dirigir o Teatro Maria Della Costa. Eu queria fazer aquilo que eu quero, as peças que eu quero, ele tinha um elenco, Fernanda estava lá e tudo. Daí o Sandro disse, Não, pra isso existe um produtor, um empresário, que sou eu. Nós podemos sentar numa mesa, eu nunca disse pra você, Não faça essa peça, não faça aquela. Eu sei aquilo que eu posso fazer financeiramente. Ele disse, Eu quero carta branca pra fazer aquilo que eu quero. Aí o Sandro disse, Não, não pode. Aí ele disse, então eu me despeço com todo o elenco. Ta bom, você pode sair. Meu marido era muito corajoso, muito bom empresário. E o Gianni Ratto saiu da minha Companhia com todo o elenco, Fernanda Montenegro, e tudo, e foram para o TBC, porque o TBC estava mais ou menos mal e ele foi lá pra dirigir uma peça, e foi lá com o elenco. Aí nós ficamos sem nenhum ator. Aí o Sandro que que fez? O Sandro contratou na Casa do Artista, também foi lá buscar senhoras velhas, e fizemos A Casa de Bernarda Alba, do Garcia Lorca, só com mulheres. Porque o meu marido não dava...entende, não tinha... não dava o braço a torcer. Ele era um homem forte, ele enfrentava qualquer um. E nunca mais ele falou com o Gianni Ratto. Teve uma ruptura, entende? Eu, a gente se encontrava e tal... Eu sempre fui nas homenagens do Gianni Ratto, porque eu gostava muito dele.

E ele gostava muito de você!!

Muito, muito.

Eu falava com ele. Ele falava principalmente da Moratória, claro que ele não ia dizer sobre o que você disse. Mas ele falava da sua generosidade..

De eu ceder o papel. 
De você ter cedido o papel pra Fernanda Montenegro.

Não mas no fundo... Eu vou te dizer uma coisa.... Se eu fosse uma egoísta , se eu quisesse realmente ser a estrela, estrelíssima, eu enfrentava o Gianni e fazia o personagem. Era a minha Companhia! Eu dizia, Gianni por favor, eu sou casada, você pára. Eu ia ter uma conversa com ele, e ia continuar. Entendeste como é? Mas como eu era uma pessoa muito sensível, e ele um grande diretor, e eu não queria perde-lo como diretor, também. Porque nós estávamos com um teatro, pagando um teatro, com um elenco grande, fazendo sucesso, ele um "puta" de um diretor entende? Como ser humano, como tudo. Com a mulher ali, então eu digo não, então deixa eu sair fora. A Fernanda, uma grande atriz.

Mas voltando a falar do Gianni, eu nunca deixei de ir a uma homenagem a Gianni Ratto. Porque pra mim o Gianni foi um homem muito importante na minha vida, no meu sucesso também como atriz, entendeste? E como ensinamento de um ser humano. Porque ele era uma pessoa generosa, fantástica. Ele tinha um gênio forte também. Os italianos tinham esse gênio. Os outros tinham muito mais do que ele. Os outros gritavam, entende? E eu não podia com gritos. Eu nunca conseguia fazer nada se um diretor chegasse pra mim e gritasse, tava perdido. Entendeste como é?Eu caía no choro e não ia pra frente. Eu sou muito sensível nessas coisas. Eu acho que o Gianni teve uma diplomacia, isso que foi o bonito do Gianni, de entender cada um, o ser humano. Porque os outros não entendiam. Eram grandes diretores e queriam eles dirigir, mas não queriam saber se você está doente, se você está assim, e aos berros - Por que você não pegou isso, por que não decorou? Não é porque eles faziam por maldade, é porque é o temperamento do italiano. Um outro italiano que eu gostei de trabalhar muito foi o Bollini. O Bollini era uma dama. O Bollini mal levantava a voz, entendeste? E o Flávio Rangel também era um homem que, às vezes, desmaiava, entende? Mas era um tipo de diretor diferente. Eu amava o Flávio. O Flávio começou praticamente comigo. Ele estava na platéia como estudante, jovem, e disse assim: Um dia eu vou te dirigir. Porque tinha aqueles debates do fím da peça né? No Canto da Cotovia, então houve uns debates. É, eu acho que era no Canto da Cotovia. Ele disse, Eu vou te dirigir um dia. Ele subia a escada .Me abraçou e beijou, e teve, veio jovem pra minha companhia, e todos os prêmios ele recebeu também. Mas o Gianni Ratto contribuiu muito para o Brasil, eu acho. Eu acho que foi um dos diretores que mais contribuiu, e que mais amou o Brasil. Ele era mais brasileiro do que eu, que sou fanática. Porque eu tive um convite pra ir pra Hollywood, com Greg Tollan, que era um grande homem de cinema, e eu disse não, quero ficar no Brasil. O Brasil é o meu país e eu vou estudar e trabalhar no meu país. Então ele me ganhou no seu patriotismo. Eu acho que falta no nosso povo é o patriotismo. Isso faz parte de nós, do ser humano, de amar o seu país e respeitar. Só assim você cria alguma coisa. Eu sou uma mulher fogosa, eu sou uma mulher que tenho...a gente usa uma frase: Não é só na cama que você tem tesão. Eu tenho tesão pra tudo na vida. Com a minha idade eu acho que ganho pra uma menina de dezoito anos. Eu to triste, eu nunca estou ...eu digo vou fazer... vou fazer. Eu acho que a gente está sempre aprendendo sempre na vida. Por isso que eu digo, o Gianni me deu essa força, esse poder de trabalho, de vida, de amar a vida, de... Eu não tive muito tempo com ele, mas foi um homem que deixou essa coisa maravilhosa pra nós. Pelo menos pra mim, e pro Sandro também. Porque o Sandro sempre amou o Gianni, sempre gostou do Gianni, apesar do desentendimento. Mas sabe, isso foi um problema que acontece no ser humano. O ser humano é forte de um lado e fraco de outro, né? Tem as suas fraquezas também. Isso é que é o bonito o ser humano. Se o ser humano fosse todo igual, 
completo, não tinha graça, né? A gente erra, acerta, segue por um caminho. Não deu certo? Pula pra um caminho e vai para uns atalhos. Eu sou assim, eu gosto da luta. Se tudo fosse um mar de rosas...Aqui no hotel.... Eu acordo e digo o que é que eu vou enfrentar hoje? Quais são os leões? Mas eu enfrento, porque tem que ter os pés no chão, tem que ter calma, tem que ter jogo de cintura. Então por que que eu sei dirigir um hotel? Porque eu tive cinqüenta anos de palco. Criei quantos personagens na minha vida? Quantos diretores que passaram pela minha vida? Meu marido me ensinou tanta coisa também! Então eu sempre estou aprendendo. Então tudo que eu aprendi, porque sou muito observadora.

È uma grande qualidade pra um artista

É pro artista. Eu sou observadora, eu olho tudo, eu sinto tudo, eu capto tudo. Eu olho pra você, eu sei o sentimento, não sei tudo, mas eu vou lá dentro de você pra ver se eu consigo te captar. Então eu acho tudo isso muito importante, e você fica jovem. Não é aquela coisa que diz todo mundo. Você não faz teatro, você não sofre? Não, não sofro. Porque? Eu fiz cinqüenta anos de teatro, meu marido morreu, perdi a tesão pelo teatro porque perdi o meu grande companheiro. Eu poderia voltar a fazer teatro, sim. Mas não encontrei um texto que me agradasse. Novela eu não gosto de fazer, porque eu sou preguiçosa pra decorar. Eu odeio decorar e ficar oito meses dentro de uma novela. Se tivesse assim uma aparição, uma participação, aí sim, mas ninguém falou nada, e também eu estou aqui dentro do hotel. Eu não gostaria também de largar o hotel, porque agora eu sou empresária. Agora 24 horas eu estou dentro do hotel. E quando eu não estou bem eu não apareço no hotel. Eu acho que eu não quero passar o meu mau humor, não é mau humor, aquilo que a gente pega durante o dia pros meus hóspedes. Eu acho que o bom astral é tudo. Por isso que o pessoal diz assim, o teu hotel tem bom astral! E depois depende também da minha pessoa pra dirigir. você vê, os meus funcionários são delicados.

Isso é reflexo de como eles são tratados.

Exatamente, como eles são tratados. Eu não sou patroa. Aqui é uma família. Trinta funcionários, nós somos uma família. A gente se reúne, bate papo, dou às vezes o meu sermãozinho em cima deles, mas nunca levantei a voz pra ninguém. E isso eu trago do teatro. A bagagem do teatro, é essa coisa que eu aprendi. A gente aprende muita coisa. E aqui também é um teatro. Você não sente falta? Não, eu já fiz muito, eu guardo boas lembranças. As coisas ruins eu jogo na lata do lixo.

Essa coisa do Sandro não ter mais falado com o Gianni, talvez porque ele gostasse muito dele e ficou magoado com o Gianni.

È, ficou magoado como Gianni. Porque o Sandro vendeu o carro, ele vendeu tudo o que tinha. Nós morávamos...Saímos dali e fomos morar no porão de uma casa de uma tia dele depois. Ficou pagando o carro do irmão. Ele ficou encalacrado com dívidas, trouxe ele da Itália, deu tudo dentro do possível pro Gianni Ratto. O Gianni fez aquilo, também impensado, na hora do amor, da paixão, sabe aquela coisa do Brasil, tudo novo. Aquela coisa da brasileira, porque o estrangeiro chega aqui... a brasileira, né? Então eu acho que o Gianni não fez aquilo por mal, mas caiu num erro que...Mas o Sandro como era também um homem muito também rígido nas suas coisas, muito honesto, mas muito sensível, ele chorava tanto quanto o Gianni chorou naquele dia que disse eu não posso 
continuar assim. O Sandro berrava, o Sandro era diferente, ele gritava, ele quebrava tudo. O Sandro era um homem que, se ele estivesse bravo, o que tinha nessa casa ele quebrava tudo. Era um homem de uma violência terrível nesse ponto. Mas depois ele sentava e chorava. A mim ele nunca me tocou, mas ele dizia, Maria você me desculpe. Ele tinha que extravasar, tanto é que ele teve um infarto por causa disso, um dia que ele não conseguiu, teve que segurar a barra e teve um infarto. E sofreu, ficou de um lado paralítico, e depois com um câncer generalizado e, foi embora, em um mês eu perdi o Sandro. No hospital, quando entrou, acabou. Era um homem que eu amei muito. Porque o Sandro era uma pessoa de uma sensibilidade, apesar de ser um homem muito forte, que eu aprendi muita coisa com ele, mas era de uma sensibilidade. Era uma mulher dentro dele, era uma mulher sensível. Eu vivia muito bem com meu marido. Eu amava muito o meu marido, e o meu marido me amava. Porque ele sempre dizia assim, as mulheres davam sempre em cima dele, e ele dizia, Não adianta! Porque eu não tenho uma única mulher, eu tenho várias mulheres. Na minha mulher eu tenho prostituta, tenho santa, tenho negra, eu durmo com várias mulheres. Ele sempre dizia. Se ele fez, fez muito bem escondido, mas no teatro jamais. Ele sempre respeitou. Ele tinha um respeito pelo teatro que nunca vi uma coisa igual. E o Gianni Ratto a mesma coisa. Um homem que viveu para sua arte. Eu me sinto orgulhosa de ter trazido o Gianni para o Brasil, eu me sinto responsável por ele. Sou responsável por um homem que veio trazer uma bagagem de cultura muito grande para o nosso país. $\mathrm{O}$ que ele ensinou para esses jovens! Isso que é o importante de falar. As rusgas que a gente teve, isso não interessa, são coisas passageiras. Mas aquilo que ele trouxe para nós, isso nós absorvemos, aprendemos, está aí! Latente! Ele deixou realmente uma coisa, uma fornalha, de atores, diretores, que observaram, que viram o Gianni Ratto, e que aprenderam a amar o Gianni Ratto. Porque o Gianni Ratto foi muito brasileiro pra nós aqui, era nosso de coração. Então eu acho que isso, as minhas palavras pro Gianni Ratto são de um carinho muito grande, e de um agradecimento, e ele sabia disso. Eu falei muitas vezes com ele quando ele estava doente, eu dizia Olha Gianni apesar de tudo que houve mas você sempre ficou no meu coração, e ele disse, Eu sei Maria, e você também, porque você - nunca vou me esquecer, ele disse - Você foi uma mulher que me deu força na hora que eu mais precisava. Porque eu podia ser uma empresária e não tomar conhecimento do problema com o Kusnet. Poderia dizer, Sandro vai lá e trata com ele. Ele foi contratado pra dirigir. O que que é? Ele está chorando por que? Ele tem que ter pulso firme em cima dos atores! Mas não, é questão de sensibilidade, eu também tinha sensibilidade e percebi. Então eu fui com o Sandro, nós dois fomos lá pra conversar com ele. Então o que que era? Era uma sensibilidade que ele tinha muito grande! Porque se fosse um homem durão ele diria, Não! Vocês têm que fazer aquilo que eu quero! Eu só fui contratado como diretor e pronto! Então que me despeçam! Ele podia ter usado as palavras. Não, ele veio, chorou, chorou muito, e eu fiquei consternada. Eu disse, pôxa, esse homem tem sentimento! E aí ele sempre disse: Maria eu te agradeço, pois eu estou no Brasil hoje por sua causa. Porque daquela conversa que nós tivemos, não tanto de seu marido, mas de você como mulher. Você era estrela absoluta, linda, maravilhosa e que você se apiedou, se consternou comigo.

Pois é, o Gianni teve uma importância muito grande para o país, pois trouxe essa bagagem de aprendizagem, de tudo, de amor ao teatro, de disciplina, de direção, nos novos diretores que surgiram nas mãos dele, novos talentos que surgiram. Porque ele passou tudo isso, passou uma cultura que ficou para o nosso país. Então, ele contribuiu de uma maneira fantástica. Não digo que os outros também não tivessem contribuído, mas o Gianni foi muito especial. Você poderia dizer, Ah, foi porque ela trouxe o Gianni, é por isso que está dizendo essas coisas. Mas não! Você deve ter feito pesquisas e visto 
a importância desse homem para o nosso teatro. A importância desse "brasileiro' no nosso país. Que foi uma coisa muito bonita, muito linda, e de um agradecimento que nós temos que ter a ele fantástico. Porque os outros vieram, foram embora, entende? Você vê, o Celi se mandou. O Bollini, que também era um grande diretor, foi pra Itália, foi dirigir televisão. Quem mais que veio? O Salce também foi embora! Mas eu acho que o Ratto foi o único, não se desfazendo dos outros, foi completo! Ele veio, trouxe tudo de bom pra nós, e ficou aqui conosco!! Entendeste? Que foi a maravilha do Gianni Ratto! E se casou com brasileira, e teve filhos brasileiros!

\section{E ele incentivou muito a dramaturgia brasileira, não é?}

Exatamente! Você veja, o Jorge Andrade fez uma peça que marcou muito no Brasil, e que deu início à dramaturgia nacional também, entende? Ele incentivou. Porque a peça dele era uma peça difícil, complicada, a história do café, com a Fernanda Montenegro, o Sérgio Britto. Foi um espetáculo, lindo, lindo, lindo! A Fernanda estava maravilhosa, o Sérgio Britto também, foi um elenco muito bom, a direção dele, o cenário...Ali também foi uma injeção de coragem para a dramaturgia brasileira também, ele deu um incentivo. Porque eu também sou muito do autor nacional. Você pode também exportar a dramaturgia nacional, como eu exportei Gimba.

E Moral em Concordata, que também foi um sucesso de sua companhia.

Isso. Que eu levei para Portugal. Porque o Abílio Pereira de Almeida apesar de ser um autor leve, mas era um autor de pensamento, que ia na ferida. Ele freqüentava a sociedade, mas fazia o retrato da sociedade também, ele não tinha dó. Ele ia lá no fundo e trazia pro palco. Quantas peças? O TBC também levou suas peças. E eu briguei em Portugal com que? Com Abílio Pereira de Almeida, porque era uma peça que batia também nas feridas dos portugueses. E eles não queriam que a gente falasse nisso, que tinha prostituta na vida.

E quando ele deixou sua companhia, e foi para o $\mathrm{TBC}$, parece que ele não ficou muito contente em trabalhar nessa casa de espetáculos, tanto que teve até desentendimento com Zampari, que não o contratou como diretor artístico da casa. Você pode falar alguma coisa sobre isso?

Ele foi pra lá pra ser diretor. Ele saiu do meu teatro por uma desavença, mas ele saiu para um porto seguro, ele estava crente que ia para um porto seguro. Mas lá era uma outra coisa. Não era o Teatro Maria Della Costa, com gente jovem, que estava sempre com tesão, o Sandro um homem de teatro, que discutia... Ah, houve uma discussão com Gianni Ratto, isso é uma coisa importante que estava esquecendo de dizer. Mirandolina, de Goldoni, que ele fez o cenário e era dirigida por Ruggero Jacobbi. Mirandolina tem vários cenários, alcova, saleta, lavanderia, pátio, etc. Então cada mudança ficava a platéia no escuro esperando que se mudasse o cenário. E aquilo era um horror. Você sabe que um segundo para o público é a mesma coisa que você esquecer um texto, uma palavra em cena que você afunda num buraco e parece que você está indo horas no esquecimento. E pro público o primeiro ia bem, o segundo já ralentava, e no terceiro já não agüentava, naquela escuridão o espetáculo esfriava, tinha que ser uma coisa rápida. Então o Sandro que estudou cenografia, que estudou no Rio de Janeiro, que entendia de cenografia e que passou a iluminação. Ele ensinou muita gente a iluminar. Flávio Rangel sempre disse isso, aprendeu com Sandro. O Sandro 
chegou, teve uma reunião com o Ratto e disse, Ratto você não pode deixar o público no escuro desse jeito, são muitos quadros. Daí o Gianni Ratto disse, Mas o que você quer que eu faça? Tem que ter meu querido, são cenas diferentes, alcova, pátio, você quer que eu faça o que? Tem que mudar, tem que ter, o público tem que ter paciência. Mas isso aqui não é Europa, o Sandro dizia. Isso aqui não é um público de uma cultura como na Itália, como no Piccolo Teatro de Milão. O brasileiro está aprendendo agora o que é teatro. E aí houve uma discussão muito grande. O Gianni bateu na mesa, sabe aquela coisa de italiano. O Sandro bateu com a cadeira, derrubou a cadeira e já iam se pegando, já partindo pra briga corporal. Você vê, a segunda, não a primeira, a segunda foi quando ele saiu. Aí ele dizia, O que você quer que eu faça? O Sandro disse, Te vira, você não é cenógrafo? Faz o cenário ir pelos ares, faz o que você quiser, mas se vira! O Gianni Ratto pegou aquilo, "cenário pelos ares". Foi pra casa e começou a pensar. O que que ele fez? Descia o cenário de cima, o da alcova por exemplo, a caminha, as cadeiras, tudo com Arlechinos, meninos vestidos, da própria Mirandolina, num tipo de balé colocando os móveis nos lugares com o palco aceso e com a platéia vendo aquilo.

Uma coisa que hoje em dia fazem normalmente.

Que hoje em dia fazem! Então você vê, o Ratto era um homem tão maravilhoso que poderia ter dito, Não, faço desse jeito e está acabado! Poderia ter encerrado o papo ali. Não, ele foi pra casa, como era um gênio, ele pegou e pensou, bom aqui como é que eu vou fazer? Então pegou os meninos e fez esse tipo de balé que os meninos mudavam o cenário colocando os elementos nos seus lugares, mudava todos os cenários assim, na frente do público. O que se tornava um segundo espetáculo, de tão lindo que era. Para completar eu queria mais uma vez afirmar a grande importância de Gianni Ratto para nosso teatro, não apenas como homem de teatro, mas principalmente como diretor, alguém que sabia como conduzir um espetáculo, sem qualquer vaidade própria, procupando-se com o resultado final, com o produto final dos seus atores, com aquilo que daria ao seu público. Bem, é isso.

Obrigado. 


\section{Trabalhos de Gianni Ratto No Brasil}

\section{TEATRO}

\section{4}

\section{O Canto da Cotovia}

Autor: Jean Anouilh

Direção, Cenário, Iluminação: Gianni Ratto

Figurinos: Luciana Petruccelli

Teatro Popular de Arte S. P. (outubro de 1954)

(Prêmio SACI para melhor espetáculo, direção, cenografia e atriz - Maria Della Costa)

\section{5}

2. Com a Pulga Atrás da Orelha - Georges Feydeau

Direção, Cenário, Iluminação: Gianni Ratto

Figurino: Luciana Petruccelli

Teatro Popular de Arte - SP (janeiro de 1955)

3. A Moratória - Jorge Andrade

Direção, Cenário, Iluminação: Gianni Ratto

Figurinos: Luciana Petruccelli

Teatro Popular de Arte - SP (maio de 1955)

\section{Mirandolina - Carlo Goldoni}

Tradução: Italia Fausta

Direção: Ruggero Jacobbi

Cenário: Gianni Ratto

Figurino: Luciana Petruccelli

Teatro Popular de Arte - SP (junho de 1955)

\section{A Ilha dos Papagaios - Sergio Toffano}

Direção, Cenário, Iluminação: Gianni Ratto

Figurinos: Lucina Petruccelli (sobre desenhos originais)

Teatro Popular de Arte - SP (dezembro de 1955)

\section{Diálogos das Carmelitas - Bernanos}

Tradução: Anibal Machado, Roberto Alvim Correa e Marina Telles Menezes

Direção: Flamínio Bollini

Cenários: Gianni Ratto

Figurinos: Carlos Bastos

Teatro Copacabana - RJ - 1955 


\section{6}

7. Eurydice - Jean Anouilh

Tradução: Guilherme de Almeida

Direção e Cenários: Gianni Ratto

Figurinos: Luciana Petruccelli

Música: Diogo Pacheco

Teatro Brasileiro de Comédia - SP (09.08.1956)

8. O Médico Volante - Molière

Tradução: Esther Mesquita

Direção e Cenários: Gianni Ratto

(Escola de Arte Dramática de São Paulo)

Teatro João Caetano - SP - 18.08.1956

9. O Demônio Familiar - José de Alencar

Direção: Gianni Ratto

Cenários e Figurinos: Alfredo Mesquita

Teatro Sociedade Alfredo Mesquita (para a EAD - SP) (19.09.1956)

10. Jacques, ou a Submissão- Eugéne Ionesco

Tradução: Alfredo Mesquita

Direção: Gianni Ratto

Teatro Leopoldo Fróes - SP - EAD - (26.11.1956)

\section{7}

11. Nossa Vida com Papai - H. Lindsay e Russel Crouse

Tradução: R. Magalhães Jr.

Direção e Cenários: Gianni Ratto

Figurinos: Kalma Murtinho

Iluminação: Gianni Ratto

TBC - SP - 04-04-1957

12. As Guerras do Alecrim e da Manjerona - Antonio José da Silva, "O Judeu". Direção e Iluminação: Gianni Ratto

Cenário e Figurino: Millôr Fernandes

Teatro Nacional de Comédia - RJ - 1957

13. O Telescópio - Jorge Andrade

Direção: Paulo Francis

Cenário: Gianni Ratto

Figurino: Kalma Murtinho

Teatro Nacional de Comédia - RJ - 1957

14. Jogos de Crianças - João Bethencourt

Direção: João Bethencourt

Cenário e Iluminação: Gianni Ratto

Figurino: Kalma Murtinho

Teatro Nacional de Comédia - RJ - 1957 
15. É de Xurupito - Walter Pinto

Direção: Walter Pinto

Cenografia e Iluminação: Gianni Ratto

1958

16. O Santo e a Porca - Ariano Suassuna

Direção: Zbgniev Ziembinski

Cenários e Figurinos: Gianni Rato

Teatro Dulcina - RJ (05.03.1958)

17. Jornada de Um Longo Dia para Dentro da Noite - Eugene O'Neill Tradução: Helena Pessoa e Gert Mayer

Direção: Ziembinski

Cenário e Figurino: Gianni Ratto

Teatro Dulcina - RJ (15-05-1958)

18. AS Três Irmãs - Anton Tchecov

Direção, Cenário e Iluminação: Gianni Ratto

Figurinos: Luciana Petruccelli

Teatro da Universidade da Bahia (09-1958)

19. O Tesouro de Chica da Silva - Antonio Callado

Direção e Iluminação: Gianni Ratto

Figurinos: Luciana Petruccelli

Teatro da Universidade da Bahia (11-1958)

\section{9}

20. A Dança dos Toreadores - Jean Anouilh

Direção: Augusto Boal

Cenários: Gianni Ratto

Teatro de Arena - SP

21. O Mambembe - Arthur Azevedo

Direção, Cenário e Iluminação: Gianni Ratto

Figurinos: Napoleão Moniz Freire

Música: Assis Pacheco e Antonio Lopes

Teatro Municipal do Rio de Janeiro (12-11-1959)

Teatro dos Sete -12 prêmios

\section{0}

22. A Profissão da Senhora Warren - Bernard Shaw

Tradução: Claudio Mello e Souza

Direção, Cenário e Iluminação: Gianni Ratto

Figurinos: Luciana Petruccelli

Teatro Copacabana - RJ - (07-05-1960) 
23. Sangue no Domingo - Walter George Durst

Direção: Ziembinski

Cenário: Gianni Ratto

Teatro Dulcina - RJ (24.05.1960)

24. Boca de Ouro - Nelson Rodrigues

Direção: Ziembinski

Cenário: Gianni Ratto

Figurinos: Tulio Costa

Teatro Federação - SP (13-10-1960)

25. Com a Pulga Atrás da Orelha - Georges Feydeau

Tradução: Miroel Silveira e Daniel Rocha

Direção, Cenário e Iluminação: Gianni Ratto

Figurinos: Kalma Murtinho

Teatro Ginástico - RJ - Prêmios de melhor espetáculo, diretor, figurino, ator (Ítalo Rossi) e atriz

(Fernanda Montenegro)

26. Gata em Teto de Zinco Quente - Tennessee Williams

Direção: Kiko Jaez

Cenário e Figurinos: Gianni Ratto

Teatro Jardel Filho - SP

\section{1}

27. Cristo Proclamado - Francisco Pereira da Silva

Direção e Cenário: Gianni Ratto

Teatro Copacabana (05 a 09/08/1960)

28. Apague Meu Spotlight - Jocy de Oliveira.

Direção e cenários: Gianni Ratto.

1961

29. Festival de Comédia :

- O Velho Ciumento - Miguel de Cervantes.

- O Médico Volante - Molière.

- Os Ciúmes de um Pedestre ou O Terrível Capitão do Mato-Martins Pena. Direção e cenários: Gianni Ratto. 1961

30. As Pequenas Raposas - Lílian Helman

Direção: João Augusto

Cenário: Gianni Ratto

Teatro Maison de France - R.J.

31. OBA! - Carlos Machado

Direção e Concepção: Carlos Machado

Cenário: Gianni Ratto

Teatro Maison de France - R.J.

32. Mirandolina - Carlo Goldoni

Direção, Cenário e Iluminação: Gianni Ratto

Figurinos: Kalma Murtinho

Teatro Ginástico - R.J. 
33. Auto da Festa de São Lourenço - Padre José de Anchieta Direção: Gianni Ratto

Teatro Nacional de Comédia - R.J. - Com alunos do Conservatório

34. Boa Noite, Bettina. - Giovanni, Garinei e Kramer

Tradução: Jô Soares e Otelo Zeloni

Direção e Cenário: Gianni Ratto

Coreografia: Ricardo Abellan

Figurinos: Aelson

Iluminação: José Alonso

Regente: George Kanzás

Teatro Record - SP

\section{2}

35. O Homem, A Besta, e a Virtude - Luigi Pirandello

Tradução: Gianni Ratto

Direção, Cenário e Iluminação: Gianni Ratto

Figurinos: Bellá Paes Leme

Teatro Maison de France - RJ (09-05-62)

\section{3}

36. César e Cleópatra - Bernard Shaw

Tradução: Miroel Silveira

Direção: Ziembinski

Cenários e Figurinos: Gianni Ratto

Música: Damiano Cozzella

Teatro Cacilda Becker - SP (15-04-63)

\section{4}

37. Diário de Um Louco - Nicolas Gogol

Tradução: Luis de Lima

Direção: Ivan de Albuquerque

Cenário: Gianni Ratto

Figurino: Walter Bacci

Teatro Dulcina - R.J.

38. A Dama do Maxim's - George Feydeau

Tradução: Bárbara Heliodora e Millôr Fernandes

Direção, cenário e iluminação: Gianni Ratto

Música: Geny Marcondes

Figurinos: Kalma Murtinho

Teatro Maison de France - R.J. (28.07.1964)

\section{5}

39. Auto da Alma - Gil Vicente

Adaptação: Walmir Ayala

Direção: Gianni Ratto

Cenário e Figurino: Bellá Paes Leme

Música: Geni Marcondes

Teatro Nacional de Comédia - RJ 
40. Se Correr o Bicho Pega, Se Ficar o Bicho Come - Oduvaldo Viana Filho e Ferreira Gullar

Direção e Cenário: Gianni Ratto

Figurino e Acessórios: Walter Bacci

Música: Geni Marcondes e Denoy de Oliveira

Teatro Opinião - R.J.

41. O Santo Inquérito - Dias Gomes

Direção: Ziembinski

Cenário e Figurino: Gianni Ratto

Teatro Jovem - R.J. (23.09.66)

\section{7}

42. A Saída, Onde Fica a Saída?- Antonio Carlos Fontoura, Armando Costa e Ferreira Gullar

Direção: José das Neves

Cenário e Iluminação: Gianni Ratto

Figurino e Acessórios: Dirceu e Maria Louise Nery

Teatro Opinião - R.J. (04-67)

43. Pedro Mico - Antonio Calado

Direção e Iluminação: Gianni Ratto

Cenário: Oscar Nyemeir

Teatro Nacional de Comédia (SNT-MEC) - RJ

44. Isso Devia Ser Proibido - Bráulio Pedroso e Walmor Chagas

Direção: Gianni Ratto

Coreografia: Marilena Ansaldi

Cenário: Cyro Del Nero

Figurino: Alceu Penna

Iluminação: Domingos Teixeira

Música: Julio Medaglia

Teatro Copacabana - R.J. (12-67)

45. Rasto Atrás - Jorge Andrade

Direção, cenário e iluminação: Gianni Ratto

Figurino: Bellá Paes Leme

Teatro Nacional de Comédia - RJ (67)

46. Mulher, Esse Super-Homem - Millôr Fernandes

Direção e Iluminação: Gianni Ratto

Cenário: Cyro Del Nero

Figurino: Alceu Penna

Música: Geraldo Vandré

Teatro Clara Nunes - RJ - 1967

\section{8}

47. Ralé- Máximo Gorki

Direção, cenário e iluminação: Gianni Ratto

Figurinos: Walter Bacci

Teatro Novo - RJ (1968) 
48. O Pequeno Príncipe - Saint-Exupery

Adaptação: Jean Michell

Direção, cenário, iluminação e figurinos: Gianni Ratto

Teatro Novo - RJ (06-12-1968)

49. Dura Lex Sed Lex No Cabelo Só Gumex - Oduvaldo Viana Filho

Direção e Iluminação: Gianni Ratto

Cenário: Carlos Fontes

Figurinos: Marie Louise Nery

Música: Dori Caymi, Francis Hime e Sidney Waisman

Teatro Mesbla - RJ - (20-12-1968)

\section{9}

50. O Marido de Conceição Saldanha - João Mohana

Direção: Ziembinski

Cenários: Gianni Ratto

Teatro Serrador - R.J. (20.03.69)

51. Ubú, Rei. - Alfred Jarry

Direção: Gianni Ratto

Figurinos: Pedro Touron

Marionetes: Illo Krugli

Música: Cecília Conde

Teatro Maison de France - R.J. (04-09-1969)

52. Beco Sem Saída - Arthur Miller

Tradução: Luiz Carlos Veiga e Pedro Veiga

Direção e Cenário: Gianni Ratto

Teatro Princesa Isabel - RJ - (19-09-1969)

\section{0}

53. Odorico, O Bem Amado - Dias Gomes

Direção e Cenário: Gianni Ratto

Teatro Princesa Isabel - RJ (18.03.70)

\section{1}

54. Abelardo e Heloísa - Ronald Millôr

Tradução: Leo Gilson Ribeiro

Direção e Iluminação: Flávio Rangel

Cenário: Gianni Ratto

Figurinos: Ninette Van Vuchelen

Música: Carlos Lyra

Direção Musical: Teo de Barros

Teatro Paiol - SP - 22.09.71) 
55. Fígaro, ou Um Dia Muito Louco. - Pierre C. de Beaumarchais Direção e Cenário: Gianni Ratto

Figurinos: Ninete Von Vuchelen

Iluminação: Luís Machi

Música: Murilo Alvarenga

Teatro São Pedro - SP - (26.04.72)

56. Por Mares Nunca Dantes Navegados - Afonso Grisoli e Tite de Lemos Direção: Afonso Grisoli

Cenário e Figurino: Joel de Carvalho

Iluminação: Gianni Ratto

Teatro Municipal - RJ - 31.05.72

57. A Capital Federal - Arthur Azevedo

Direção: Flávio Rangel

Cenário: Gianni Ratto

Figurinos: Ninette Von Vuchelen

Iluminação: Zé da Silva

Coreografia: Marika Gidali

Direção Musical: Teo de Barros

Teatro Anchieta - SP - 10.03.72

58. A Grande Imprecação Diante dos Muros da Cidade - Tankred Dorst

Tradução: Thereza Linhares e Carlos Queiroz Telles

Direção, Cenário, Figurino e Iluminação: Gianni Ratto

Coreografia: Rafael Rodriguez

Teatro São Pedro - SP - 16/10/1972

\section{3}

59. Frank V - Friedrich Dürrenmatt

Direção: Fernando Peixoto

Cenário e Figurinos: Gianni Ratto

Teatro São Pedro - SP - março de 1973

60. Caminho de Volta - Consuelo de Castro

Direção: Fernando Peixoto

Cenário e Figurino: Gianni Ratto

Teatro Aliança Francesa - SP

61. Dr. Fausto da Silva - Paulo Pontes

Direção: Flávio Rangel

Cenário: Gianni Ratto

Figurino: Fernando Azevedo

Teatro Gláucio Gil - RJ - setembro de 1973 
62. Um Bonde Chamado Desejo - Tennessee Williams

Direção: Kiko Jaez

Cenário e Figurino: Gianni Ratto

Iluminação: Abel Kopanski

Música: Paulo Herculano

Teatro Anchieta - SP - 1974

63. PIPPIN - Roger Hirson e Stephen Schartz

Direção: Flávio Rangel

Cenário: Gianni Ratto

Figurinos: Kalma Murtinho

Teatro Adolfo Bloch - RJ (20.06.1974)

64. O Jogo do Poder Segundo Shakespeare - Carlos Queiroz Telles

Direção, Cenário, Figurino e Iluminação: Gianni Ratto

Teatro Aliança Francesa - SP - 1974

\section{5}

65. O Atelier de Madame Zazá - Georges Feydeau

Direção: José Renato

Cenário: Gianni Ratto

Figurinos: Kalma Murtinho

RJ (01-1975)

66. Ricardo III - William Shakespeare

Tradução: Carlos Queiroz Telles e Mariângela Alves de Lima.

Direção: Antunes Filho

Cenário, Figurinos e Adereços: Gianni Ratto

Música: Conrado Silva

Teatro Municipal de Campinas - 1975

67. O Duelo - Bernardo Santareno

Adaptação e Direção: Roberto Vignati

Cenário e Iluminação: Gianni Ratto

Figurinos: Gláucia

Música: Amilson Godoy

Teatro Oficina - SP - 1975

68. Mumú, a Vaca Metafísica - Marcílio Soares

Direção: Flávio Rangel

Cenário: Gianni Ratto

Figurinos: Kalma Murtinho

Teatro Nacional de Comédia - RJ (01.12.1975)

69. Um Estranho Casal - Neil Simon

Direção: Jô Soares

Cenário e Iluminação: Gianni Ratto

Teatro Ipanema - RJ - 1975 
70. Os Executivos - Mario Chaves

Cenário e Iluminação: Gianni Ratto

Teatro São Pedro - 1975

71. Gota D'Água - Oduvaldo Viana Filho, Paulo Pontes e Chico Buarque Direção, Cenário e Iluminação: Gianni Ratto

Teatro Tereza Raquel - RJ - 1975

SP -1977

\section{6}

72. Ponto de Partida - Gianfrancesco Guarnieri

Direção: Fernando Peixoto

Cenário e Figurinos: Gianni Ratto

Teatro TAIB - SP - 09-1976

73. Vivaldino, Criado de Dois Patrões - Carlo Goldoni

Direção: José Renato

Cenário: Gianni Ratto

Figurinos: Kalma Murtinho

Teatro Casa Grande - RJ - 1976

\section{7}

74. O Barbeiro de Nichteroy - Antônio Pedro e Flávio Santiago

Direção: Antonio Pedro

Cenário e Iluminação: Gianni Ratto

RJ - 1977

75. Delírio Tropical - Stanislaw Witkiewcz

Tradução: Sonia Samaia

Direção: Emílio di Biasi

Cenário e Figurino: Gianni Ratto

Iluminação: Abel Kopanski

Música: Conrado Silva

Teatro FAAP - SP - 1977

76. Pequenos Burgueses - Maximo Gorki

Direção: Renato Borghi

Cenário e Figurinos: Gianni Ratto

Trilha Sonora: Paulo Herculano

Teatro TAIB - SP - 1977

77. Sonata Sem Dó Para Três Executantes - Marcilio Moraes

Cenário: Gianni Ratto

Teatro Eugenio Kusnet - SP - 1977

78. Os Saltimbancos - Chico Buarque

Direção: Silney Siqueira

Cenário e Figurinos: Gianni Ratto

Teatro da Universidade Católica (TUCA) - SP - 1977 
79. O Diário de Anne Frank - Frances Goochich e Herbert Hachett Direção: Antonio Mercado

Cenário e Iluminação: Gianni Ratto

Teatro Paiol - SP - 1977

\section{8}

80. Gata em Teto de Zinco Quente - Tennessee Williams

Direção Kiko Jaez

Cenário, Figurino e Iluminação: Gianni Ratto

Teatro Brigadeiro - SP - 1978

81. O Grande Amor de Nossas Vidas - Consuelo de Castro

Direção, Cenário, Figurinos e Iluminação: Gianni Ratto

Teatro Paiol - SP - 1978

82. Caixa de Sombras - Michael Christopher

Direção: Emilio Di Biasi

Cenários e Iluminação: Gianni Ratto

Teatro FAAP - SP - 1978

83. Murro em Ponta de Faca - Augusto Boal

Direção: Augusto Boal

Espaço Cênico: Gianni Ratto

Teatro TAIB - 1978

1979

84. O Rei de Ramos - Dias Gomes

Direção e Iluminação: Flávio Rangel

Cenário: Gianni Ratto

Figurinos: Kalma Murtinho

Coreografia: Fernando Azevedo

Música: Chico Buarque e Francis Hime

Teatro João Caetano - RJ (11.03.1979)

85. Lola Moreno - Bráulio Pedroso

Direção: Antonio Pedro

Cenário e Figurinos: Gianni Ratto

Música: John Neschling

Teatro Mesbla - RJ (1979)

86. Um Rubi no Umbigo - Ferreira Gullar

Cenário - Gianni Ratto

87. Com a Pulga Atrás da Orelha - Georges Feydeau

Direção, Cenário, Iluminação: Gianni Ratto

Com Osvaldo Loureiro e Zilka Saberry

Teatro Bloch - Rio de Janeiro - 1979 
88. Gota D’Água - Oduvaldo Viana Filho, Paulo Pontes e Chico Buarque de Holanda

Versão para o Espanhol: Denise de Kalafe

Direção, Cenário, Iluminação: Gianni Ratto

Figurino: Walter Bacci

Direção Musical: Murilo Alvarenga

Coreografia: Renato Magalhães

Teatro de La Nacion - Ciudad de México - México (26.03.80)

\section{Sérgio Cardoso em Prosa e Verso}

Direção e Iluminação: Gianni Ratto

Teatro Sérgio Cardoso - SP - 13.10.1980

\section{1}

90. A Venerável Madame Goneau - João Bethencourt

Direção e Iluminação: Gianni Ratto

Cenário: Cyro Del Nero

Figurinos: Alceu Penna

Teatro Paiol - SP - 1981

\section{2}

91. A Eterna Luta Entre o Homem e a Mulher - Millor Fernandes

Direção, Iluminação e Cenário: Gianni Ratto

Figurinos: Kalma Murtinho

Acessórios: Marie Louise Nery e Pádua

Teatro Clara Nunes - RJ - 25.09.1982

92. Amadeus - Peter Schaffer

Tradução: Flávio Rangel

Direção e Iluminação: Flávio Rangel

Cenário: Gianni Ratto

Figurino: Kalma Murtinho

Teatro Adolfo Bloch - RJ - 18.03.1982

93. Vidigal, Memórias de Um Sargento de Milícias. - Millôr Fernandes Direção e Iluminação: Gianni Ratto

Cenário: Darlaff Lopes Pereira da Silva

Coreografia: Carlota Portela

Figurino: Millan Fernades

Musica: Carlos Lyra

Teatro João Caetano - RJ - 06.1982

94. Desencontros Clandestinos - Neil Simon

Tradução: Marisa Murray

Direção e Iluminação: ?Gianni Ratto

Cenário e Figurino: Augusto Francisco

Teatro A Hebraica - SP - (05.03.1982) 
95. Hedda Gabler - Henrik Ibsen

Tradução Millôr Fernandes

Direção: Gilles Gwizdek

Cenário e Iluminação: Gianni Ratto

Figurino: Kalma Murtinho

Teatro Guairinha - Curitiba (1982)

Teatro Gláucio Gil - RJ - 1983

\section{3}

96. PIAF- Pam Gems

Tradução: Millôr Fernandes

Direção e Iluminação: Flávio Rangel

Cenário: Gianni Ratto

Figurino: Kalma Murtinho

Teatro Ginástico - RJ (25.05-1983)

\section{Oito Mulheres - Robert Thomas}

Direção: Kiko Jaez

Cenário e Iluminação: Gianni Ratto

Teatro Hilton - SP - 1983

98. VARGAS - Dias Gomes e Ferreira Gullar

Direção e Iluminação: Flávio Rangel

Cenário: Gianni Ratto

Figurinos: Kalma Murtinho

Teatro João Caetano - RJ - 03.10.1983

\section{4}

99. Freud, No Distante País das Almas - Henry Denker

Tradução: Flavio Rangel

Direção e Iluminação: Flávio Rangel

Cenário: Gianni Ratto

Figurino: Kalma Murtinho

Teatro Clara Nunes - RJ - 22.03.1984

100. Oh! Calcuta! - Kenneth Tynam

Tradução: Lilio Alonso e Gilberto di Piero

Direção: Kiko Jaez

Cenário: Gianni Ratto

Coreografia: Marielena Ansaldi

Direção Musical: Wanderley Martins

Teatro Brigadeiro - SP - 05.1984

101. Negócios de Estado - Louis Verneuil

Tradução: Flávio Rangel

Direção e Iluminação: Flávio Rangel

Cenário: Gianni Ratto

Figurino: Kalma Murtinho

Teatro Hilton - SP - 15.05.1984 
102. Com a Pulga Atrás da Orelha - Georges Feydeau

Tradução: Gianni Ratto

Direção, Cenário e Iluminação: gianni Ratto

Figurino: Kalma Murtinho

Teatro Procópio Ferreira - SP (22.09.1984)

103. O Leito Nupcial - Jean de Hartog

Tradução: Miriam Mehler e Emilio di Biasi

Direção: Emilio di Biasi

Cenário: Gianni Ratto

Figurino: Lu Marton

Iluminação: Gianni Ratto e Emilio di Biasi

Teatro FAAP - SP - 1984

\section{5}

104. O Que o Mordomo Viu. - Joe Orton

Tradução: Flávio Rangel

Direção e Iluminação: Flávio Rangel

Cenário: Gianni Ratto

Figurinos: Kalma Murtinho

Teatro Clara Nunes - RJ (25.02.1985)

105. Louco Circo do Desejo - Consuelo de Castro

Direção: Vladimir Capella

Cenário e Iluminação: Gianni Ratto

Teatro Maksoud Plaza (12-1985)

\section{6}

106. Cyrano de Bergerac - Edmond Rostand

Tradução: Ferreira Gullar

Direção e Iluminação: Flávio Rangel

Cenário: Gianni Ratto

Figurino: Kalma Murtinho

Coreografia: Clarisse Abujamra

Direção Musical: Murilo Alvarenga

Teatro Cultura Artística - SP (05.09.1986)

107. DRÁCULA - Hamilton Deane e John Balderston.

Tradução: Isabel Sobral e Gianni Ratto

Direção, Cenário e Iluminação: Gianni Ratto

Figurino: Kalma Murtinho

Trilha Sonora: Túnica

Teatro Procópio Ferreira - SP 1986 
108. Os Amores De Tennessee Williams - Paulo Wolff

Direção: Kiko Jaez

Cenário: Gianni Ratto

Figurinos: Guilherme Guimarães

Iluminação: Gianni Ratto e Kiko Jaez

Teatro Municipal de Santos (06.04.1987)

Teatro Maksoud Plaza - SP - (24.04.1987)

109. Ladrão Que Rouba Ladrão- Dario Fó

Tradução Malú Rocha e Herson Capri

Direção, Cenário e Iluminação: Gianni Ratto

Figurino: Miguel Paiva

Música: Claudio Savietto

Teatro Galuce Rocha - RJ (23.10.1987)

\section{8}

110. O Amante de Madame Vidal - Louis Verneuil

Tradução: Millor Fernandes

Direção, Cenário e Iluminação: Gianni Ratto

Figurino: Kalma Murtinho

Teatro Hilton - SP - 1988

\section{9}

111. A Vida de Galileu - Bertolt Brecht

Tradução: /Roberto Shwarz

Direção: Celso Nunes

Cenário: Gianni Ratto

Figurino: Kalma Murtinho

Iluminação: Aurélio de Simoni

Teatro Gairinha - Curitiba (15.08.89)

\section{0}

112. Uma Ilha para Três - André Roussin

Tradução: Jaci Lage

Direção, Cenário e Iluminação: Gianni Ratto

Música: Murilo Alvarenga

Teatro Bibi Ferreira - SP - (14.03.1990)

113. Em Busca dos Bons Momentos - Teatro Infantil - Paulo Pélico

Direção: Roberto Lage

Cenário, Figurino e Adereços: Gianni Ratto

Coreografia: Vivien Buckup

Direção Musical: Julio Medaglia

Teatro Dias Gomes - SP - 1990 


\section{1}

114. Lettice e Lotte - Peter Shaffer

Direção: José Renato

Cenário, Figurino e Iluminação: Gianni Ratto

Teatro Brasileiro de Comédia - SP - 11.1991

\section{2}

115. Lisístrata - Aristófanes

Direção, Figurinos e Adereços: Gianni Ratto

Teatro Célia Helena - SP (26.06.1991)

116. Senhoritas Q.D. - Cristina Bueno e Inês Viana

Direção e Iluminação: Gianni Ratto

Cenário e Figurinos: Aby Cohen

Teatro Municipal de Campinas (03.1992)

\section{3}

117. Porca Miséria - Jandira Martini e Marcos Caruso

Direção e Iluminação: Gianni Ratto

Cenário e Figurinos: Renato Scripilitti

Trilha Sonora: Aline/ Túnica (Mídia Play Produções)

Teatro Bibi Ferreira - SP (06.01.1993)

118. O Mambembe - Arthur Azevedo

Direção, Iluminação: Gianni Ratto

Cenário e Figurinos: Augusto Francisco

Coreografia: Ana Maria Spier

Música: Eduardo Seincman

Teatro TUSP - SP - (07/93)

119. As Bruxas (Entre Mulheres) - Santiago Moncada

Tradução: Marcos Caruso

Direção, Iluminação: Gianni Ratto

Cenário: Renato Scripilitti

Figurino: Leda Senise

Teatro Sala São Luís - SP (21.10.1993)

\section{4}

120. A Última Carta - Nicola Martin

Tradução: Edla Van Steen

Direção, Cenário, Figurino, Iluminação: Gianni Ratto

Teatro Centro Cultural - SP (03.94)

121. Morus e Seu Carrasco - Renato Garielli

Direção, Cenário e Ilumnação: Gianni Ratto

Música: Oliviero pluriano

Figurino: Fabio Namatame

Teatro Ruth Escobar - SP (17.10.1996) 


\section{8}

122. Entrevista - Fernando Moreira Salles

Direção: Maria Lúcia Pereira

Espaço Cênico e Iluminação: Gianni Ratto

Teatro SESC POMPÉIA - SP (04.02.1998)

123. VERMOUTH - Aimar Labaki

Direção, Cenário e Iluminação: Gianni Ratto

Figurino: Fábio Namatame

Preparação Corporal: Ariela Goldman

Direção Musical: Aline Meyer

Teatro Itália - SP (17.04.1998)

2000

124. O Acidente - Bosco Brasil

Direção: Ariela Goldman

Cenário e Ilumnação: Gianni Ratto

Teatro Porão - Centro Cultural São Paulo (27.03.2000)

125. O Papagaio Verde - Arthur Schnitzler

Direção: Ariela Goldman

Cenário e Iluminação: Gianni Ratto

Teatro da EAD - SP (30.11.2000)

\section{1}

126. Uma Vida No Teatro - David Mamet

Direção: Francisco Medeiros

Cenário e Iluminação: Gianni Ratto

Teatro Municipal de Avaré (17.06.2001) - Circuito do Interior Paulista

\section{2}

127. Selvagem Como o Vento - Tereza Freire

Direção: Denise Stoklos e Hugo Hojas

Cenário e Iluminação: Gianni Ratto

Casa de Cultura Laura Alvim - RJ - maio/2002

128. Novas Diretrizes Em Tempo de Paz - Bosco Brasil

Direção: Ariela Goldman

Iluminação: Gianni Ratto

Agora - 2002 


\title{
TEATRO LÍRICO
}

\section{5}

1. ZAZÁ

Música: LEONCAVALLO

Regente: Nino Verchi

Direção e Cenário: Gianni Ratto

Figurino: Luciana Petruccelli

Teatro Municipal do Rio de Janeiro (18.06.55)

\section{9}

\section{A MENINA DAS NUVENS}

Música: Heitor Villa Lobos

Baseado em conto de Lucia Benedetti

Regente: Heckel Tavares

Direção, Cenário, Figurino e Iluminação: Gianni Ratto

Teatro Municipal do Rio de Janeiro

\section{2}

\section{IL DIBUK}

Música Lodovico Rocca

Libreto: Renato Simoni

Regente: Nino Stinco

Direção, Cenário e Iluminação: Gianni Ratto

Coreografia: Tatiana Leskova

Teatro Municipal do Rio de Janeiro (13.09.1962)

\section{FALSTAFF}

Música: Giuseppe Verdi

Libreto: Arrigo Boito

Regente: Edoardo De Guarnieri

Direção e Ilumnação: Gianni Rattto

Cenários: Arlindo Rodrigues, Bellá Paes Leme, Newton Sá

Coreografia: Tatiana Leskova

Teatro Municipal do Rio de Janeiro (04.10.62)

\section{4}

\section{WERTHER}

Autor: Massenet

Direção, Cenário, Figurino e Iluminação: Gianni Ratto

Teatro Sodré - Montevideo - Uruguai (03.1964)

\section{6}

\author{
6. EL RETABLO DE MAESE PEDRO \\ Autor: Manuel de Falla \\ Regente: Isaac Karabtchevsky \\ Direção e Iluminação: Gianni Ratto \\ Cenário: Illo Krugli \\ Bonecos e marionetes: Illo Krugli e Pedro Touron \\ Sala Cecília Meireles - Rio de Janeiro (02.12.1966)
}


7. PETER GRIMES

Música: Benjamim Britten

Libreto: Montagu Slater

Regente: Henrique Morelembaum

Direção, Cenário e Iluminação: Gianni Ratto

Figurino: Maria Luiza Néri

Teatro Municipal do Rio de Janeiro (21.10.1967)

\section{TOSCA}

Autor: Puccini

Direção e Iluminação: Gianni Rato

Teatro Municipal do Rio de Janeiro

\section{CAVALLERIA RUSTICANA}

Autor: Mascagni

Direção, Cenário e Figurino e Iluminação: Gianni Ratto

Teatro Municipal do Rio de Janeiro

\section{PAgLiaCi}

Autor: Leoncavallo

Direção, Cenário, Figurino, e Iluminação: Gianni Ratto

Teatro Municipal do Rio de Janeiro

\section{1}

\section{ELIXIR DO AMOR}

Música: Gaetano donizetti

Libreto: Felice Romani

Regente: Diogo Pacheco

Direção, Cenário e Figurinos: Gianni Ratto

Teatro Municipal de São Paulo (23.10.1971)

\section{6}

\section{IL TABARRO}

Música: Giacomo Puccini

Cenário e Iluminação: Gianni Ratto

Regente:

Teatro João Caetano - Rio de Janeiro

\section{GIANNI SCHICCI}

Autor: Giacomo Puccini

Cenário e Iluminação: Gianni Ratto

Teatro João Caetano - Rio de Janeiro

\section{IL CAMPANELLO}

Autor: Donizzetti

Direção, Cenário, Iluminação: Gianni Ratto

Teatro Municipal de Niterói 
15. AMAL OU OS VISITANTES DA NOITE

Autor: Menotti

Direção, Cenário e Iluminação: Gianni Ratto

Teatro Municipal de Niterói

\section{7}

\section{SALVADOR ROSA}

Música: Antonio Carlos Gomes

Libreto: Antonio Ghislanzoni

Regente: Maestro Simon Blech

Direção, Cenário e Figurinos: Gianni Ratto

Teatro Municipal doe São Paulo (09.09.1977)

\section{8}

\section{SARGENTO DE MILÍCIAS}

Autor: Francisco Mignone

Direção: Gianni Ratto

Teatro Municipal do Rio de Janeiro

\section{LO SCHIAVO}

Música: Antonio Carlos Gomes

Libreto: ${ }^{\text {a }}$ Taunay e R. Paravicini

Regente: David Machado

Direção, Cenários , Figurino e Iluminação: Gianni Ratto

Teatro Leopoldina - Porto alegre (31.07.1979)

Teatro Municipal de São Paulo (21.09.1979)

Teatro Solis - Montevideo - Uruguai

\section{0}

\section{DON GIOVANNI}

Música: Wolfgang Amadeus Mozart

Libreto: Lorenzo de Ponte

Regente: David Machado

Direção, cenário, figurinos e iluminação Gianni Ratto

Coreografia: Dennis Gray

Teatro Municipal do Rio de Janeiro (12.09.1980)

\section{1}

\section{LA BOHEME}

Música: Giacomo Puccini

Libreto: Giuseppe Giacosa e Luigi Illica

Regente: Enrique Morelembaum

Direção e Iluminação: Gianni Ratto

Cenário: Aldo Calvo

Teatro Municipal de São Paulo (16.10.1981) 
21. SUOR ANGELICA

Autor: Giacomo Puccini

Direção, Cenário, Figurino e Iluminação: Gianni Ratto

Regente: Túlio Colaciciopo

Teatro Municipal de São Paulo

\section{LA VIDA BREVE}

Autor: De Falla

Direção: Silney Siquiera

Cenário e Figurino:Gianni Ratto

Teatro Municipal de São Paulo

\section{CARMINA BURANA}

Autor: Carl Orff

Cenário, Figurino: Gianni Ratto

Teatro Municipal de São Paulo

\section{2}

\section{A FLAUTA MÁGICA}

Música: Wolfgang Amadeus Mozart

Libreto: Emanuel Schikandeder e Carl Ludwig Giesecke

Regente: Giory Fischer

Direção, Cenário, Figurino e Iluminação: Gianni Ratto

Teatro Municipal do rio de Janeiro (07.07.1982)

\section{WOYZECK}

Autor: Alban Bnerg

Regente: Isaac Karabtchevsky

Direção Fernando Peixoto

Cenário e Figurino: Gianni Ratto

Teatro Municipal de São Pualo (05.12.1982)

\section{3}

\section{O ELIXIR DO AMOR}

Música: Donizetti

Libreto: Eugene Scribe

Regente: John Neschling

Direção: Antonio Pedro

Cenário e figurino: Gianni Ratto

Teatro Municipal do Rio de Janeiro (21.10.83)

\section{4}

\section{DON GIOVANNI}

Música: Woolfagang Amadeus Mozart

Libreto: Lorenzo da Ponte

Regenet: John Neschling

DireçãoÇ Gianni Ratto

Cenário: Lominik Hartman

Coreografia: Armando Jorte

Teatro Nacional de São Carlos - Lisboa (15.01.84) 


\section{5}

\section{LA CENERENTOLA}

Música: Gioachino Rossini

Libreto: Jacopo Ferretti

Regente: John Neschling

Direção: Gianni Ratto

Cenografia: Alfredo Furiga

Teatro Nacional de São Carlos - Lisboa (07.07.85)

\section{6}

\section{O GUARANI}

Música: Carlos Gomes

Libreto: Antonio Scabrini e Carlo D"Ormerille

Regência: Maestro Roberto Duarte

Direção: Cenárioe Iluminação: Gianni Ratto

Coreografia: Silvio Dufrager

Figurinos: Acervo da Funarj

Teatro Municipal do Rio de Janeiro (12.03.1986)

\section{O BARBEIRO DE SEVILHA}

Autor: Rossini

Regentes: Romano Gandolfi e Roberto Duarte

Direção, cenário, figurino e iluminação: Gianni Ratto

Teatro Municipal do Rio de Janeiro (08/1988)

\section{NORMA}

Autor: Bellini

Direção e iluminação: Gianni Ratto

Cenário e Figurino: Acervo

Teatro Municipal de São Paulo (23.07.1989)

\section{DON GIOVANNI}

Autor: Wolfgang Amadeus Mozart

Regente: Henrique Morelembaum

Direção, concepção cênica, iluminação: Gianni Ratto

Teatro Municipal do Rio de Janeiro (08/1981)

\section{RIGOLETTO}

Música: Giuseppe Verdi

Libreto: Francisco Maria Piave

Regente: Alceo Bocchino

Direção, cenário e iluminação: Gianni Ratto

Figurinos: Tony Silveira

Coreografia: Jair Moraes

Teatro Guaíra - Curitiba (20-11-1991) - remontagem em 08/1992) 
34. A QUEDA DA CASA DE USCHER

Música: Philip Glass

Libreto: Arthur Yorinks

Regente:Thomas Toscano

Direção: Harrry Silvenstein

Cenografia e iluminação: Gianni Ratto

Figurinos: Carmela Gross

Teatro Sala São Luís - SP (16/03/1992)

\section{5. ÓPERA DO CAFÉ}

Texto: Mário de Andrade

Música: Hans Joachim Kollreutter

Direção: Fernando Peixoto

Cenário: Gianni Ratto

Figurinos: Maria do Carmo Brandini

Regência: Luís Gustavo Petri

Teatro Municipal de Santos (13-09-1996) 


\section{BALÉ}

\section{O DESCOBRIMENTO DO BRASIL}

\section{Autor: Heitor Villa Lobos}

Regente: Alceo Bocchino

Direção, cenário e iluminação: Gianni Ratto

Coreografia: Tatiana Leskova e Eugenia Feodorova

Figurino: Bellá Paes Leme

Teatro Municipal do Rio de Janeiro (1960)

\section{TEMPORADA DE MARGOT FONTEYN E NUREYEV}

\section{- DANÇA EM QUATRO INSTRUMENTOS}

Música: J. S. Bach

Coreografia: Dalal Achkar, Nino Giovanetti, Gilberto Mor

Cenário: Gianni Ratto

Figurino: Bea Feither

\section{- METASTASIS}

Música: Iannis Xenakis

Coreografia: Nina Verchinina

Cenário: Gianni Ratto

Figurino: Julya Van Rogger

Regente: Henrique Morelembaum

Teatro Municipal do Rio de Janeiro (25/04/1967)

\section{CONVERGÊNCIAS/RHYTHMETRON}

Música: Marlos Nobre

Coreogria: Arthur Mitchell

Cenografia: Gianni Ratto

Figurino: Maria Luisa Néri

Teatro Novo - Rio de Janeiro - 11.06.1968 (Para a Companhia Brasileira de Ballet)

\section{UM BALLET AMERICANO}

Música:

Coreografia: W. Dollar

Cenário, iluminação: Gianni Ratto

Teatro Municipal do Rio de Janeiro

\section{AS CRIATURAS DE PROMETEU}

Música: Ludwig Van Beethoven

Argumento, direção, cenário e iluminação: Gianni Ratto

Figurino: Bellá Paes Leme

Coreogrfia: Dennis Gray

Regência: Mario Tavares

Teatro Municipal do Rio de Janeiro (31.10.1970)

\section{COPELIA}

Música: Delibes

Coreografia: Tatiana Leskova

Cenário e iluminação: Gianni Ratto

Regente: Henrique Morelembaum

Teatro Municipal do Rio de Janeiro 


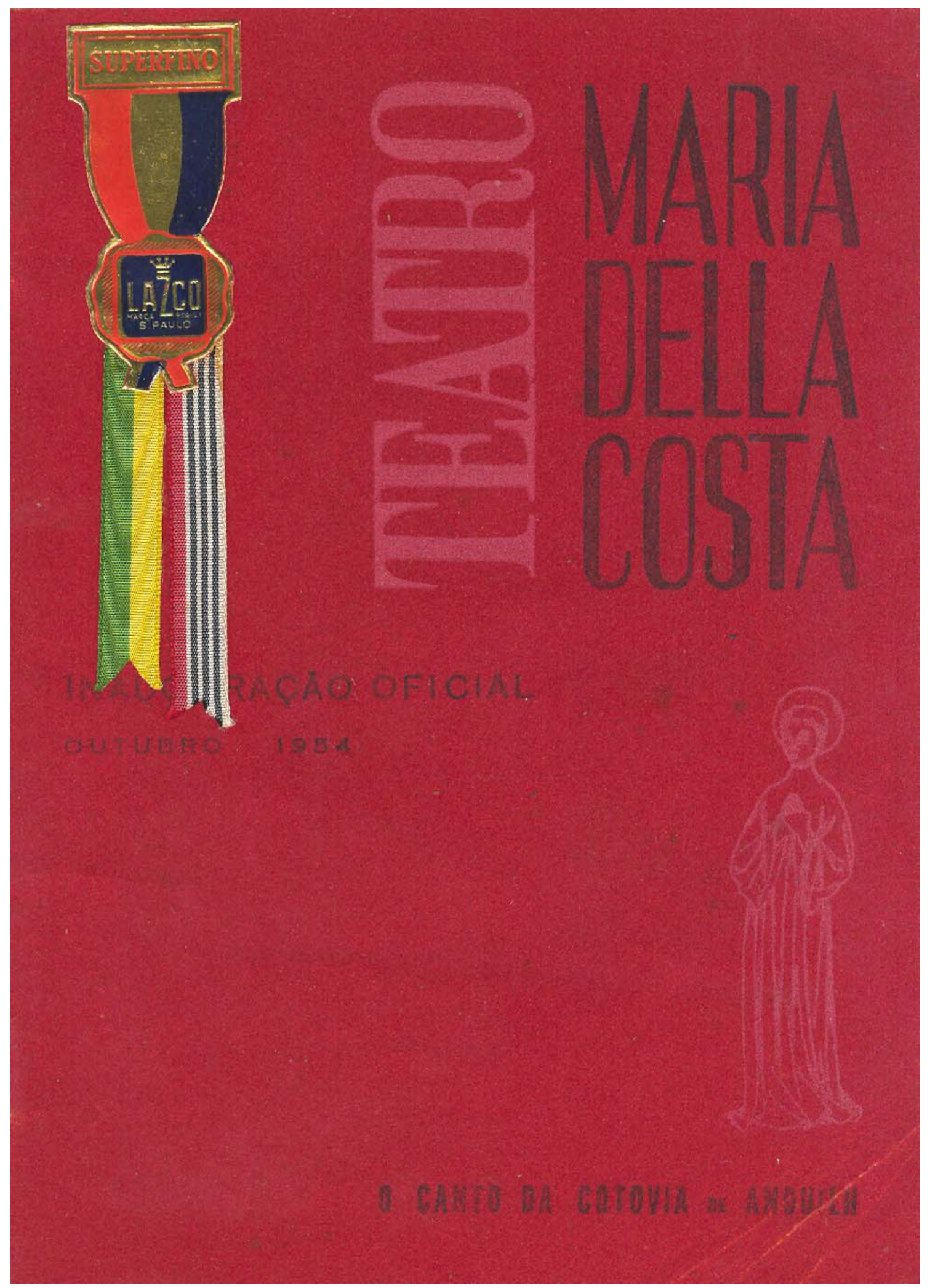




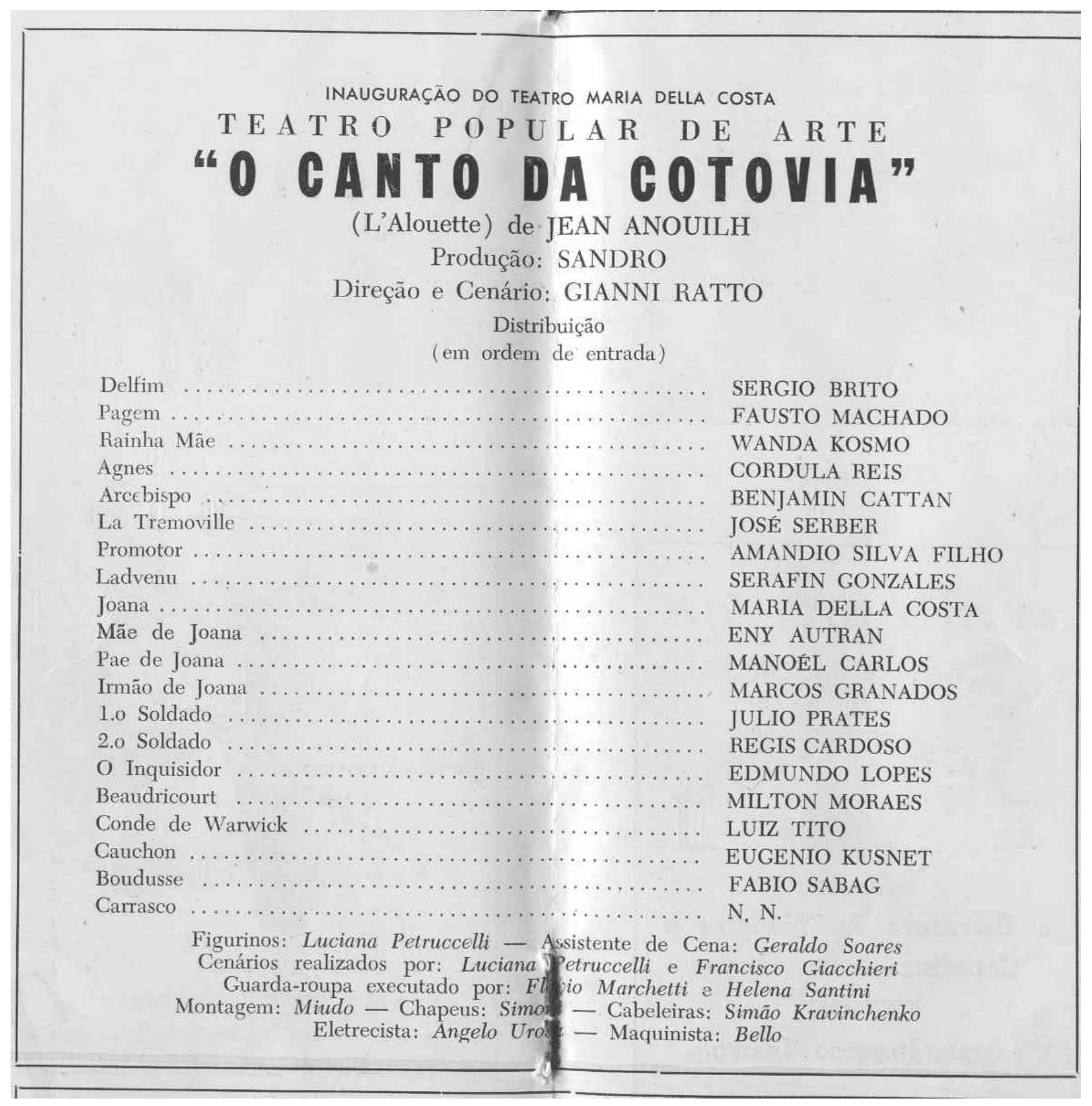




\section{O tEAtro pOpUlar dE ARTE}

Após as experiencias iniciais realizadas por Maria Della Costa, Sandro e Italia Fausta nos diferentes setores em que haviam trabalhado, compreendeuse que era o momento propício para a concretização de uma atividade própria. Assim, em princípios de 1948, resolveram fundar o "Teatro Popular de Arte", realizando a primeira temporada no Teatro Fenix, do Rio de Janeiro. Conforme o nome indica, os objetivos desse grupo eram, e são, de fazer um teatro de nível artístico destinado ao povo.

"Anjo Negro", de Nelson Rodrigues, foi a peça de estreia, sob a direção de Ziembinski, seguindo-se "Tobacco Road" (que lançou Ruggero Jacobbi como diretor, no Brasil), "Teresa Raquin”, sob a direção de Italia Fausta, "Woyzek" de Büchner, direção de Ziembinski, e "A Respeitosa”, de Sartre. Vindo a São Paulo, para o Municipal, daqui fizeram ponto de partida para todos os estados do Sul, numa excursão que demorou cerca de oito méses, durante os quais os espetáculos foram apresentados aos públicos locais tal como haviam sido vistos nas capitais.

Regressando a São Paulo, inaugura. ram com "No fundo do poço" de Helena Silveira, as atividades teatrais do grande auditório do Teatro Cultura Artística, encenando ainda "A Família Barret" de Rudolf Besier e "A escola das cocottes" de Armont e Gerbidon. Com todo esse repertório, subiu a companhia para o Norte do país, fazendo todas as principais cidades até Belém do Pará e Manaus.
Após certo período, no qual se dedicaram a atividades cinematográficas, Sandro e Maria reorganizaram o elenco e encenaram "Manequim" de Henrique Pongetti, percorrendo novamente os estados do Sul, re-encenando ainda "Desejos" de O’Neill. Em São Paulo, acertaram com o Banco Nacional Imobiliario, hoje Companhia Nacional de Investimentos, a construção deste teatro, à rua Paim, esquina de avenida 9 de Julho. Seguiram para a Europa, onde viajaram, estudando, em mais de 10 paises, inclusíve vários estados da União Sovietica.

Regressando ao Brasil, re-encenaram "Volta, Mocidade" (Come back, little Sheba) de William Inge, e encenaram "Um drama em casa do diabo", de Toño y Manzanos. Já ia adiantada, por essa altura, a construção do teatro, $e$ as atividades externas foram abandonadas para haver uma concentração de esforcos a $m$ torno do novo empreendimento. $\mathrm{Na}$ Itália, foi convidado o ensaiador Gianni Ratto para orientar o elenco, que ora se apresenta, em casa própria, com o original de Anouilh "O canto da cotovia" (L'Alouette).

Resumindo a breve e diligente vida do Teatro Popular de Arte, pode-se dizer que, ao alcançar seu porto, sua casa, de onde novos horizontes ainda maiores o esperam, têm os seus fundadores a segurança de não terem faltado ao compromisso que assumiram perante si próprios: o de levar ao povo um teatro de inteligencia, beleza, e cultura. 


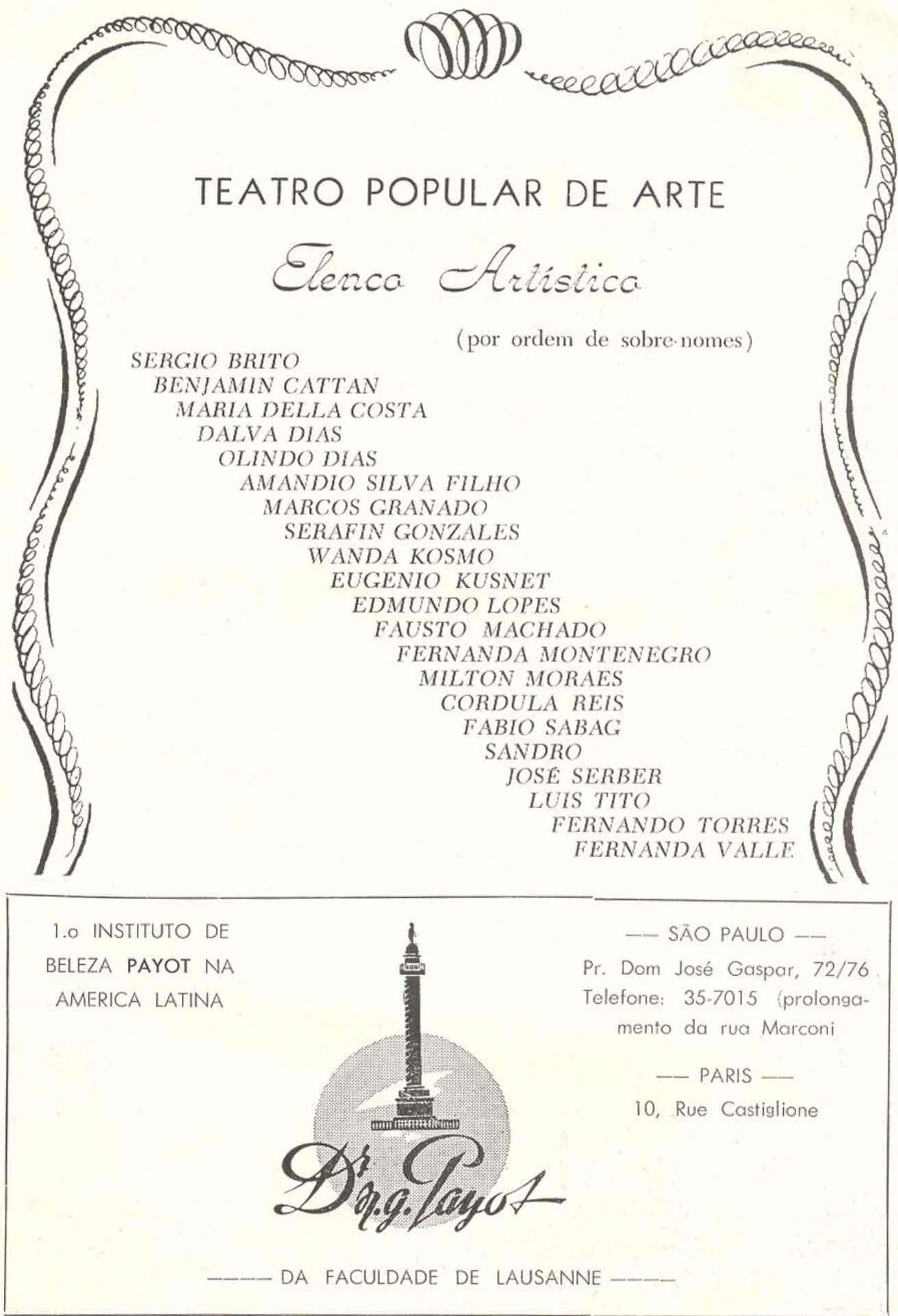




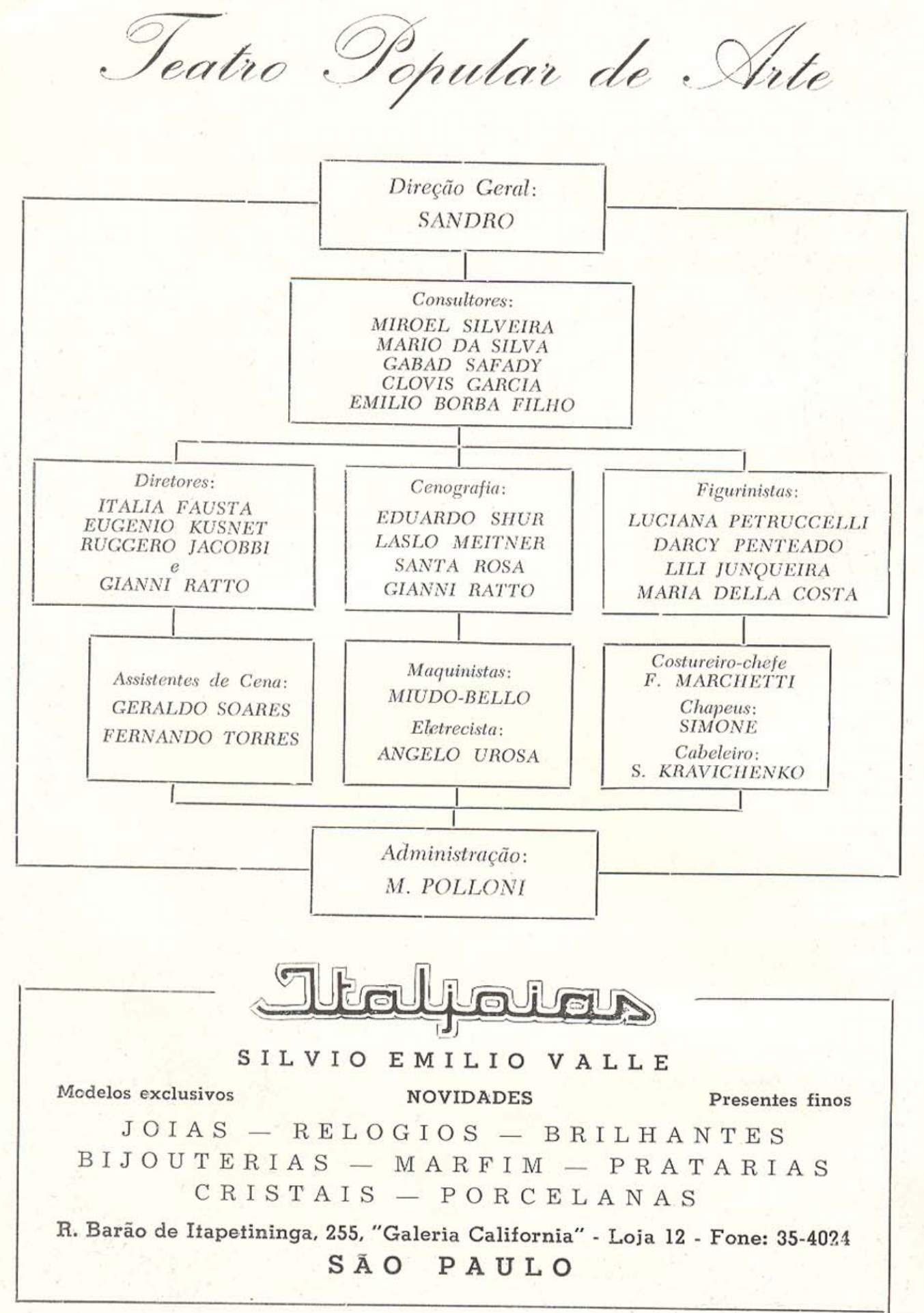




\section{$G|A N N|$}

R A T T O

Nascido em Milão - Italia - a 27 de agosto de 1916, tendo estudado e cursado: Liceu ArtisticoUniversidade, faculdade de Arquitetura e o Centro Experimental de Cinematografia - escola de direção. Apesar de sua formação artistica ser autoditada, todavia de-

1) ao arquiteto Mario Labò, de Genova, que foi seu mestre guia nas ar arquitetura

2) no teatro: a Gordon Craig e a Pietro Sharoff (este, por
sua vez, aluno de Stanislasua vez,
wski):

3) no cinema: a Luigi Chiarini, Umberto Barbaro e Alexandro Blasetti.

Ocupa-se de teatro e cinema desde 1932, então com a idade de 16 anos. Após uma interrupção de oito anos, devido à segunda grande guerra, onde serviu como como "partigiano" reiniciou suas atividades em
1946 , tendo realizado dahi para cá cerca de 130 espetaculos (todos documentados)

Nessa reentrée, por questão de conciência profissional, não quiz enfrentar a responsabilidade da direçáo total, como anteriormente e preferiu aperfeiçoar-se nos seus conhecimentos dos problemas do teatro, dedicando-se especificament à cenografia e à colaboração em geral. Com isso amadureceu e assimilou antes experiência e para êle, hoje, a direçāo advêm de um lógico completamento de uma longa experiência aprofundada em todos os campos do espetáculo, da tecnica, e da realizaçao dos valôres estéticos aos textos a serem representados. Por outro lado, cone um simples trabalho e, com tal entender, assim se tem dedieado toda a vida e pretende continúar a fazê-lo.

Para bem comprovar isso, basta enumerar os Peguintes fátos, que realizou de 1946 a data de hoje: - Para companhias de prosa -50 espeta-
culos:

Para teatros estáveis: Emi Milão, no Piccolo Em Genova, no Piccolo Teatro - 7 espetaculos:

Em Florença, no Piccolo Teatro -1 espetaculo:

- Para teatros líricos: Em Milăo no Teatro Scala - 17 espetaculos;

Em Florença no Comunale - 1 espetaculo;

Em Roma no Opera - 2 espetaculos: - Para teatro de revista: Em varios, ao rêdor de 10 espetaculos:

- Para teatro ao ar livre: Em Florença, Veezia e S. Miniato -3 espetaculos;

- Para outras formações e atividades, vários espetaculos menores.

Por ocasiao das celebrações Colombianas da cidace de Genova, realizou uma grande maniduzentos participantes.

No campo do cinem. além de ter participado em documentários e pequenas metragens, minou de realizar, recentemente, como cenôgrafo e consultôr artistico em côres, filme "Orizzonti del Sole", produzido na Italia em "Ferraniacolor".

Participou e colaborou na fundaçấo dos seguintes teatros estaveis, na Italia: o Piccolo Teatro de Milấo; o Piccolo Teatro de Genova e o Piccolo Teatro de Florença.

Foi, por dois, anos vice-diretor cênico do Teatro Scala, de Milao. Trabalhou com os seguintes diretores: Giorgio Strehler, Guido Salvani, Car Ebbert, Adolfo Celi, Vito Pandolfi, Luciano Lucingnani. Mario Landi, André Barsacq, Mario
Frigerio, Erbert Graf, Vittorio Gassman, Sergio Guerrieri, Ettore Giannini, Giannini, Gerardo outros.

Trabalhou também com os seguintes coreografos: Boris Romanoff, Aurelio Millos, Dino Cavallo, Ghisa Geert, Rosita Lupi, Njota Injoca e etc.

Também com os seguintes diretores de orquestras: Nino Sanzogno, Igôr Strawinski, Jonel Perlea, Franco Capuana, Carlo Maria Giulini, Guido Rosada, Ferdinand Leitner. Argeo Quadri, ErVon Karajan, Victor de Sabata, Issada, Ferdinand Leitnex, Argeo Quadri, Lrbert Von Karajan, Victor de Sabata, Issay Dobroven, Tullio

Desenvolveu suas atividades também como: pintor, redator, publicista, conferêncista, espositor e etc.

Possue uma bellisima e vasta bibliografia (livros, jornais e revistas) relativa á sua atividaUma

dos espetaculos por ele reade êxito para exportados da Italia, com granca, Alemanha Franca, Dinamarca Suiça, Belgiruega, Inglaterra, Brasil (Carosello Napoletano), Uruguai e Argentina.

Com êsse extraordinário homem de teatro é que Maria Della Costa e Sandro, num encontro casual na Italia, por ocasião de sua recente viagem ao velho mundo, tiveram a ooprtunidade de conhecê-lo e imediatamente adveio a hipótese da possibilidade de lhe oferecer em vir realizar aqui no Brasil, tudo de quanto já fêz e poderia vir a fazer, nêste teatro, que naquela ocasião estava em planos, mas que agora é uma realidade concreta, absolutamente novo de energias e de propósitos.

Gianni Ratto, homem de formaçăo e principios tão invulgares, não titubiou em aceitar imediatamente tal oferta para vir dar a sua excepcional colaboração ao teatro Nacional, mesmo que isso the custasse, como the custou de fato, porquanto deixou em sua pátria, uma situação e conceituação das mais marcantes nêstes ultimos tempos, conseguida com grandes lutas sacrificios e tôrmentas, deixando, enfím, uma situação previlegiada e invejável, para dar a êste nosso teatro Nacional um pouco mais do que necessita.

Fica aqui, pois, consignados de público os mais sincêros e ardorosos agradecimentos a Gianni Ratto nẫo só de Maria Della Costa e Sandro, como do Teatro Nacional Brasileiro, pelo que ja féz, com os votos que muito mais venha a fazer, porquanto capacidade, fé e vontade não the faltam. 
Sa existe no mundo um personagem com qual é difícil gracejar, e mais difícil ainda, não levar a serio, em toda sua nobre austeridade de santa e guerreira, êste personagem é Joana d'Arc.

Anouilh, todavia, transfigura a santa, reconduzindo-a a proporçóes que the parecen mais coerentes às suas necessidades de autor. Utiliza-a com todo o refinamento e habilidade de um autêntico homem do "metier", apelando, mais uma vez, a um recurso muito seu, qual seja, de falar dos seus contemporâneos camuflando os nas vestes dos antepassados, sejam êstes históricos ou literarios.

Erronco seria, sem dúvida, julgar èste tra balho baseando-se no rigorismo científico; ha jiv visto o conjunto de interpretaçoes discordantes que existcm sôbre Joana e os acontecimentos da sua vida.

A retórica de um Cauchon, figura sórdida c mesquinha, Anouilh contrapóe por exemplo, um homem quase involuntàriamente retórico, de palavras envolventes, seguro, capaz de julgar a si mesmo e aos outros, mas impotente, devido a um conformismo adquirido, diante do sistema do qual êle mesmo faz parte.

Joana, antes de assumir a sua fisionomia do figura legendária - a brandir a espada e o estandarte - é uma simples camponesa que acredita cegamente nas suas "vozes" interiores, ao serviço das quais oferece, sem restricōes, a franqueza e a agressividade inerentes á sua origem campesina. Parece que o seu problema, para ser resolvido, não deve se limitar à procura de uma enviada de Deus. mas de uma criatura que se atira à luta maior que as suas possibilidades naturais, sob o $\mathrm{im}$. pulso de uma especie sugestão dificilmente calculável e cuja proporçẫo escapa à sua avaliaçăo consciente. E' verdade que ela retratará a sua abjuração; porém, mais por um: certa intransigência sublime do que por uma impecável profissão de fé

$\mathrm{Na}$ realidade, não acreditamos muito nesta divindade que acompanhou Joana. Estamos mais convencidos e nos apoiamos na procura que cada um faz em si mesmo para atingir as conclusões correspondentes a uma moralidade válida e que deve ser restaurada.

"Deus, se o quizeres" - são as palavras de Warwick. Mas será Deus o homem que vence em Joana? E năo seria também a sua posterior santificação, o reconhecimento de valores humanos que de Deus se aproximam? Se pretendemos identificar o homem com Deus. então é do tema divino que devemos falar. Mas se o homem sobrevive, independente, sozinho, então é em si mesmo onde encontraremos os argumentos para a defesa contra tôda a série de fatores negativos e de obstáculos que os outros homens deitam sobre os seus caminhos. A gloria de Joana corresponde, portanto, à felicidade companheira das nossas mais puras e conscientes atitudes.

Anouilh traca um desenho geométrico e so. bre o centro de uma tela de aranha lança, debatendo-se, a jovem que ninguém poderá vencer, porque no final é o tema da pureza que triunfou e que sempre triunfará, no limiar de uma transformacão retorica, apesa das insidias mais sutis e dos ataques mais diretos. O conflito entre a pureza e um mundo sempre ávido de destrui-la, para depois s comover, está claramente definido nas pala. vras de Warwick, quando visita Joana no cárcere. 'E' um estado de graça ser donzela. Nos homens adoramos isso, e, infelizmente, assim que encontrarmos uma, nos apressamos em fazer dela mulher, e pretendemos que o milagre continue... que loucos que somos.

Năo se trata portanto de uma interpretacão histórica e nem mesmo de um julgamento cujas pretençôes sejam concluir definitivamen te o probl:ma. Substituindo os nomes de Warwick, de Joana, de Cauchon, do Promotor, do Inquisidor, do Delfim, de Aqnes, o resultado será o mesmo, apenas com a diferença que teremos, ao invés de um drama histórico, uma amarga e sorridente análise da nossa sociedade.

Apesar de tudo isso, parece ser esta a mais autêntica de tôdas as Joanas de tempos em tempos apresentadas pelo teatro, pelo meno a mais atual, a mais clara. E' fácil nela reconhecer as nossas mais secretas aspiraçōes: a necessidade de lutar pelos mais puros va lores dissolvidos pela indiferença geral, sacrificados por uma loucura coletiva que nos impede, constantemente, de reconhecermo-nos reencortrarmo-nos.

A ansiedade esistencialista que em tudo vî valores negativos, que nega possibilidades de redenção, é destruida por Anouilh. Apesa de uma aparente distância, mascarada nas vestes de um humorista amargo, superior e ao mesmo tempo encantado, lança mensagens que nos apressamos a recolher e retrasmitir.

A retórica não deve nos amendrontar. Também não devemos nos apavorar diante dos lugares comuns. Ocorre ainda nāo se envergonhar das vozes secretas que nossa consciência reaviva continuamente e que nos, por conformismo e por cautela, reprimimos ao mais profundo do nosso subconsciente.

O problema de "L'Alouette" não está na figura histórica de Joana d'Arc. Joana é um nome emprestado, assim como o são aqueles dos outros personagens. O problema está numa humanidade muito nossa e atual, embora Anouilh se apresse em declarar a impossibilidade de falar de seus contemporaneos.

"O canto da cotovia" oferece, à margem destas consideraçôes, a oportunidade para a presentação de um espetáculo. $\mathrm{O}$ desenho, construção procuram se articular ao texto de tal maneira que a cenografia escapa a qualquer consideração de ordem decorativa para se tornar fator de expressão dramática. O mesmo se pode dizer do vestuário que adere mais à psicologia dos personagem que a um pretensioso rigorismo histórico.

Gianni Ratto 


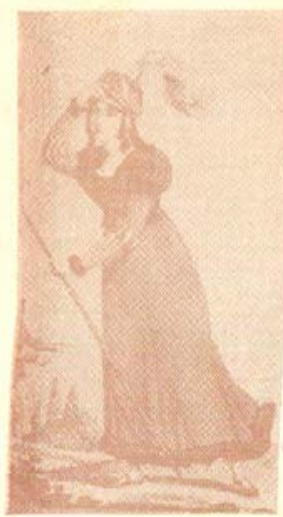

\section{DATAS E FATOS DA VIDA DE JOANA D'ARC}

JANEIRO 1412 - JOANA D'ARC nasceu no vilarejo de Domremy. Seu pai, Jacques d'Arc e sua mãe Isabel Romee, eram lavradores vivendo de um pequeno patrimonio. Na época do nascimento de Joana, a sisesperadora rava há mais A guerra dueulo: comecou em 1.337 . quando o rei da inglaterra. Eduardo Isabel de Franca, havia tentado reunir os dois paises sob o mesmo cétro. EsMlle Riviere - 1812 ta tentativa continuou com cezes dividiram-se em dois partidios: os favoraveis ao duque de Orieans e os do duque de Borgonhà. ve dos innãos de Carlos vi de França, com a mor-

e dis: Marre e unico herdeiro ao trono.

Orleans Morre chefe do partido do duque de 1.419: O

João duque Delfím, com ínicia uma aço de Borgonha, gleses. No dia 7 de setembro o duque é assassinado pelos companheiros do Delfim. govo duque de Borgonha, Filipe, reconhece Rei da França Henrique $\mathrm{V}$ da Inglaterra, Carlos VI deserda seu filho. 1,420: Pelo tratado de Troyes. Henrique $\mathrm{V}$ empenha-se em: 1.o Assumir o titulo do regente da França; 2.0 Casar-se com Catarina, fina de Carlos VI, glaterra sob a mesma e In3.o) Negar direito Coroa: Delfim, considerado bastardo: 1.422: Henrigue $\mathrm{V}$ e Carlos vi morrem: o Delfim carlos proclamar rei da França e coroar em Poitiers. Os seus inimigos, por escarneo, o chamam Rei de Bourges para onde ele se retira cansado e aborrecido, deixando 0 governo nas mãos dos especuladores. 1424: Joana tem a pri-
meira visão. Como diria

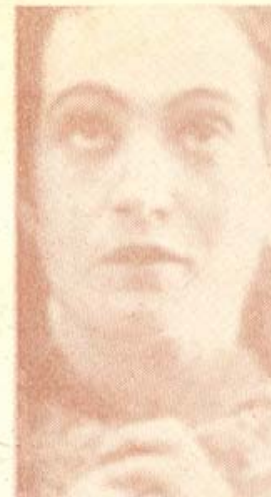
terstava eu no decimo tercelro ano de minha vida, quando Deus mancou uma voz para gujar-me. Primeiro fiquei apavorada. A vóz voltou de novo. No dia anterior eu havia feito jejum." Segundo as palavras de Joana na os Espiritos que ela vê são: O arcanjo Miguel. Sta, Catarina e Sta, Mar Sta. Catc

1.428: Joana tem dezesseis anos, tenta chegar Chinon. Fala com Roberto de Daudricourt, governador de Vaucoulers, Diz-lhe que enviada de Deus, que ela pocie ajuctar o Delfim a sal- var a França. Baudricourt não the dá ouvido.

OUTUBRO 1428: Os ingleses cercam Orléans.

JANEIRO 1429: Joana deixa Domrémy.

23 de fevereiro $1.429-$ Joana consegue persuadir Baudricourt de que ela pode salvar a França,

6 de março de $1.429-0$ Delfim recebe Joana que nhor dos Céus para segurar-te que serás coroado na cidade de Reims antes que o ano findo". ABRIL 1.429: O Delfim permite a Joana provar com fatos sua missão divina: cavalgando dentro de uma armadura branca, com seu estandarte com sua espada, à testa do exército que vaí em socorro de Orleans.

MAIO 1.429: Os capitães Iranceses estão convencido. que Joana é mesmo enviada de Deus para ajuda-los. las $(7$ de malo), Joana cai

O inimigo está para ser der. rotado. O duque de Bedror discipulo do demónio que usou suas artes de feiticeira".

8 de maio 1.429: Os ingleses deixam Orléans. O exército do Delfim se recolhe para rezar. agradecendo a Deus a vitória conseguida.

29 de junho 1.429: O Delfim Joana marcham sobre Reims do Delfim em Meims com o título de: Carlos VIr, rei da França

23 de maio de 1.430: Joana caí prisioneina dos Ingleses perto de Compiegne.

24 de outubro de $1.430^{\circ}$ : Depois de longo peregrinar cle prisăo em prisio, após

cuas tentativas de evasão, Joana é vendida aos ingleses por Joa de Luxemburgo, por 10.000 escudos de

9 de janeiro de 1.431: Em Rouem sé reunem vários da Universidade a égide ris, favoravel aos ingleses, Joana é processada com grande solenidade. 30 de maio de 1.431: Joana é excumungada e queimada viva como hereje. 1.894: Um decreto de Leão XIII declara Joana

1909: Pio X proclama Joana Beata,

16 de maio de 1.920 : Benedito XV escreve o nobum de santos.

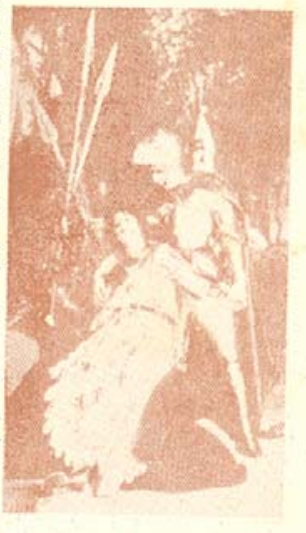

Julia Marlowe - 1906

Elisabeth Bergner - 1925 


\section{MUSEU}

DE ARTE DE SÃO PAULO
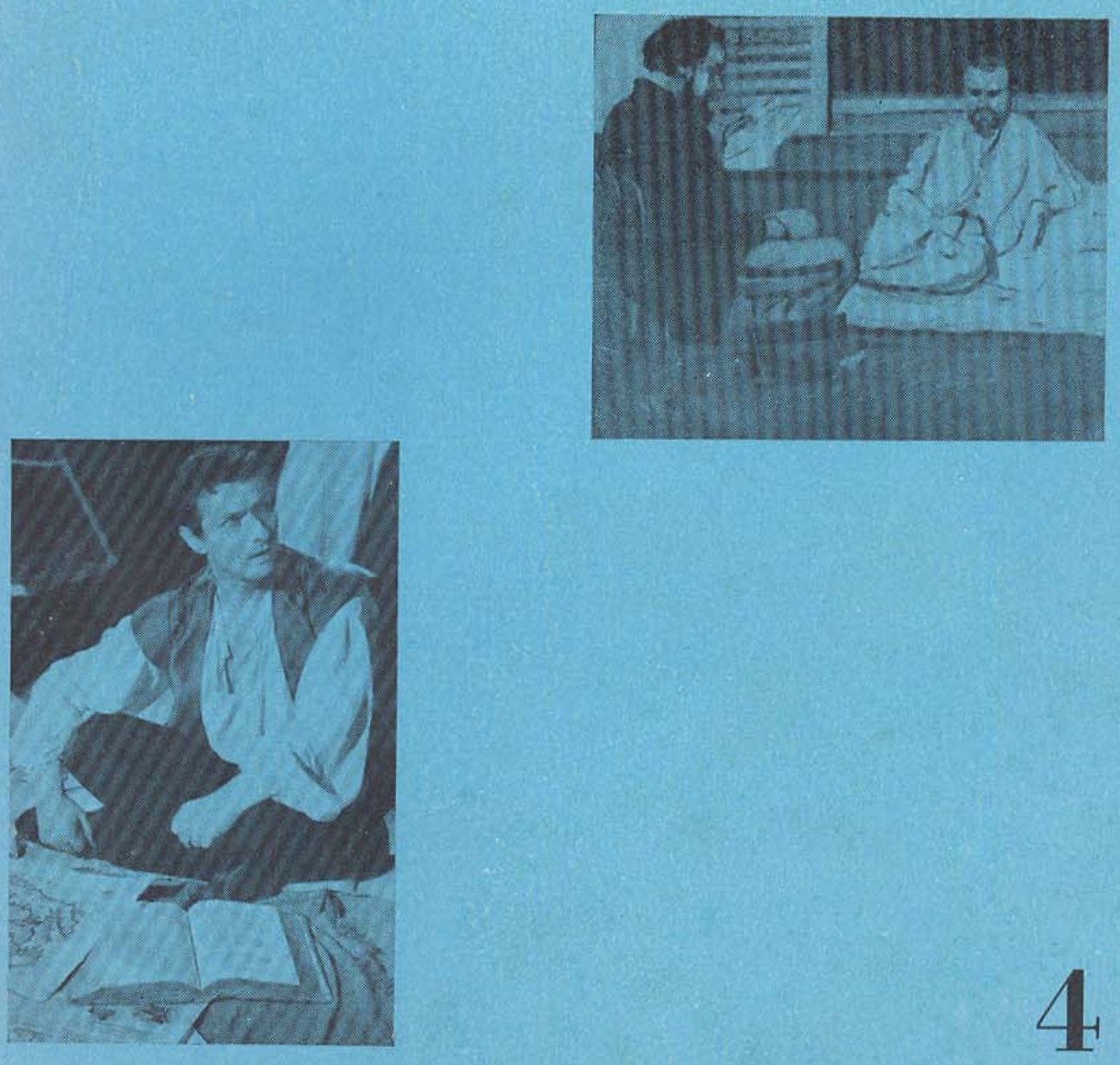
0 novo departamento do Museu

Os motivos que sugeriram a criação do Departamento de Teatro (que conterá com a colaboração do novo teatro de Maria della Costa), são apresentados no esquema abaixo.

Essas razões ultrapassam, é óbvio, uma simples enunciação e os fins desta iniciativa do Museu de Arte visam atender a necessária co-participação entre os mais diversos campos artísticos que têm pontos comuns e recíprocos interêsses. Fácil exemplo foi a Renascenca, durante a qual os artistas eram ecléticos por excelência, sem que êste fato viesse perturbar a unidade de cada investigação; procurando a perfeição em cada arte particular por êles executada, de.monstraram como sòmente através do profundo conhecimento de todos os problemas e de tôdas as técnicas, podiam chegar à melhor expressão de um mundo estético que se realizava quer na pintura, quer na arquitetura ou na música. Leonardo foi também homem de teatro, Brunelleschi e Michelangelo foram poetas, pintores, arquitetos e inventores de máquinas teatrais e de guerra. As invenções de Sabbatini, que em 1600 escreveu uma "Prática para a elaboração de cenários e máquinas de teatro" resultaram talentos e múltiplas invençôes da Renascença. O mecenatismo de um tempo permitiu que muitos artistas, passando da ourivesaria aos afrescos, à construção de edifícios, estabelecessem uma continuidade profissional, efetuando recíproco aprofundamento dos vários temas. A evolucão da história, as guerras, as revoluções, mudaram profundamente a estrutura da nossa sociedade. $O$ que antes era patrimônio de uma elite limitada, tornou-se, pela difisuão da cultura, patrimônio público. Ao ecletismo, substituiu-se a especializaç̃̃ $о$ a cada qual procura encontrar sua própria linguagem de maneira que the pertença mais diretamente. O mecena que se circundava de artistas e artesães, substituiuse atualmente pela organização social de atividades culturais, na qual cada participante torna-se, por assim dizer, mecenas de si próprio. Isto torna possível o retôrno a uma origem que permita intercâmbios mais amplos e mais proveitosos. Todos estão convidados a participar como atores ou como espetadores destes problemas e temas teatrais. Ao mecenatismo iluminado por poucos privilegiados, se substituem os organismos que se inclinam a concentrar num único ponto de apoio, as várias atividades, limitando a dispersão e estimulando, sobretudo, a análise de problemas que se constituem como componentes de uma única fôrça: a arte, em todo imenso alcance de seus significados. A iniciativa do Museu representa, portanto, grandes possibilidades neste campo, aqui no Brasil.

O Departamento de Teatro completa, hoje, êste centro de atividades - o Teatro não mais considerado como motivo de distração domingueira, mas como um enorme objeto de investigação e pesquisa. A finalidade dêste Departamento deve ser a de enfrentar os problemas do Teatro e examiná-los, juntando os têrmos de sua linguagem aos de outras artes, como um vínculo estreitando-as entre si, todos os interêsses artísticos.

O Departamento de Teatro propõe-se à formação de uma cultura teatral que, encontrando na presença ativa dos autores teatrais brasileiros sua princippal finalidade, possa caminhar paralelamente à história do teatro contemporâneo e fornecer a base para o estabelecimento de uma tradição, concebida como produção de obras em solução de continuidade, quer no plano intelectual, 
quer no plano diretamente profissional. Em sua atuação, o Departamento de Teatro enfrentará problemas e temas de caráter estético e técnico, ligados à arte de representação teatral, tendo como ponto de partida, a idéia de que nenhuma arte de natureza individual ou coletiva pode viver se não se relacionar, absorvendo-as, com as experiências e cânones das demais. Procurará ainda exercer uma influência direta no público e, principalmente, naquele de categorias que, por motivo de órdem econômica, se mantém afastadas do teatro. As atividades dêsse novo Departamento obedecerão, portanto, a um programa de manifestações teatrais a serem realizadas em contato direto com o público, estendendo-se, além disso, a exposiçóes de pintura, fotografia, cenografia, etc., sempre relacionadas com a vida teatral, e promovendo, ainda, espetáculos extraordinários de obras teatrais, inclusive musicados e de câmera.

É o seguinte o programa das atividades:

Conferências: Em cada primeira sexta-feira do mês, haverá conferência ou palestra sôbre um argumento de órdem técnica (ator, cenografia, iluminação, arquitetura teatral, costume, cenotécnica, etc.)

Em tôdas as segundas-feiras do mês, será realizada uma conferência de caráter informativo, histórico ou estético (relacão do teatro com as outras artes; teatro musical, teatro de revista, relacão entre o texto e a representação, a interpretação dramática, os autores, a direção, etc. etc.). As palestras, conferências e os relatórios críticos, estarão a cargo de pessoas idôneas no plano teórico e profissional, qualquer que seja a arte de sua especialização.

Debates: Tôda terceira sexta-feira do mês será dedicada aos debates concernentes tanto ao teatro, como ao cinema. Êsses debates serão organizados em conjunto com o Departamento de Cinema do Museu de Arte. Serão realizados, cada mês, de- bates públicos após a apresentacão dos espetáculos teatrais programados. Leitura de Textos: Na última sexta-feira do mês será feita, com várias vozes, a leitura dos diversos trechos nacionais ou estrangeiros, que embora oferecendo particular interêsse cultural não podem ser apresentados nos teatros, quer pelo elevado custo de sua produção, ou por dificuldade de órdem técnica.

Reuniôes Extraordinárias: Reuniōes extraordinárias, prèviamente participadas aos sócios, serão promovidas tôdas as vezes que personalidades do mundo teatral passarem por esta Capital.

Concursos: Ainda em estudo está a organização de um concurso nacional para um texto teatral. Nos próximos boletins serão dadas maiores informações.

\section{Giani Ratto é} o responsável pelo Departamento de Teatro do Museu. Trata-se de um profissional que fez o melhor de sua experiência no teatro italiano. Estudou na Faculdade de Arquitetura da Politécnica de

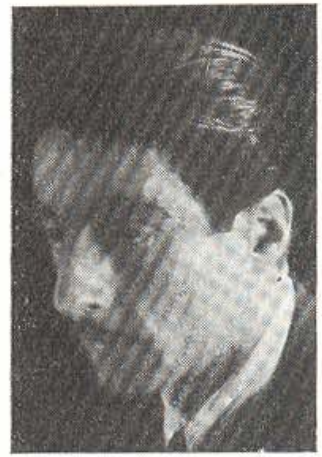

Milão, e também concluiu os estudos da Secção de Direçâo do "Centro Sperimentale di Cinematografia" de Roma. Suas atividades teatrais iniciaram-se em 1932. Depois da guerra realizou cerca de 130 espetáculos, dos quais 38 no "Picollo Teatro" de Milão. No setor de cenografia ocupou o cargo do vice-diretor do Teatro da Scala de Milão; isso em 1950-51. Participou, igualmente, como cenógrafo e consultor artistico para a côr, no filme "Gli orizonti del sole" dirigido por Giovanni Paulucci, realizado recentemente na Itália em "Ferraniacolor". Agora trabalha no teatro de Sandro e Maria della Costa, dirigindo-o artisticamente. 
O Teatro de Maria della Costa inaugurará sua temporada com o "Canto da Cotovia" de Anouilh, cujo personagem central é Joana D'Arc. Quando esta surge, assume imediatamente o sabor de lenda, transcendendo a elementar e rigorosa avaliação dos seus atos. Como todos os personagens de valor universal, concentrando em si os aspectos mais autênticos e contraditórios do pensamento e das aspiracões humanas, Joana D'Arc inspirou inúmeros poetas, músicos, historiadores e artistas que a viram como heroina, mistificadora, bruxa, santa, possessa, inspiradora ou comandante de armas. Ainda não se apagara o éco de sua morte, já se criava a lenda, e, em 1435, Christine de Pizan escrevia um "Poème de Jeanne d'Arc" que foi ilustrado com lindíssimas miniaturas.

"Les vigiles du Roi Charles VII" concluiram, em figuracões explendidas, uma história que era ainda crônica. Shakespeare, em "Henrique VI" analisa-a vigorosamente, embora de um ponto de vista absolutamente negativo. Villon a cantará na "Ballade du temps de jadis". No séc. XVII, Chapelaine a idealiza, enquanto que no século XVIII, Voltaire tornará a queimála, sob o fogo prepotente e destruidor de sua ironia anti-clerical. Ainda em 1795, Robert Southey enfrentará o tema pouco depois retomado em "Die Jungfrau von Orleans" de Schiller, que construiu em torno de sua figura uma imponente tragédia por êle mesmo definida romântica. O século XIX é rico em "Pucelles" e Joanas d'Arcs as vezes ironizadas ou glorificadas, às vezes viviseccionadas com um rigor histórico que tende a reabilitar a martir, a destruir a lenda, a avaliar o processo, considerando de vez em vez iniquos ou justos, os juizes que, cegos de dogmas ou embrutecidos pelo medievalismo das superticões, passaram para a historia. Chegaram a destruir, através de volumes e volumes, a crenca que Joana d'Arc tenha existido. Assim temos de Jules Quicherat o "Proces de condamnation et réhabilitation de Jeane d'Arc dite la Pucelle", seguido por Soumet que escreveu "L'ebopée de Jeanne d'Arc". As monografias de Henri Wallon, Marius Sefet, Gabriel Hanateaux, Joseph Fabre, Simeon Luce, tôdas elas vão ter no comovido, sutil e profundo estudo de Anatole France, que talvez seja o mais válido e interessante ensáio sôbre Joana d'Arc. Um drama de Barbier foi musicado por Gounod.

Muitos são os músicos que se inspiraram em Joana d'Arc e aqui lembramos, além do já citado Gounod, Anseulm Weber, Rudolf Kreutzer, Karl Wagner, Johann Schultz, Franz Destouches, Nicola Vaccai, Giovanni Pacini, Michael Baffe, Franz Liszt, Francesco Malipiero e finalmente Giuseppe Verdi que escreveu "Giovanna d'Arco", baseando-se no livreto de Temistocle solera. A ópera do maior compositor italiano, também julgada interessante e sensível, não é todavia senão um pálido esbôço daquela que será a producão sucessiva do "Cigno di Busseto". Nos primeiros anos de 1900, Sarah Bernhardt interpretou o imponente e acadêmico drama de Emile Moreau "Le procés de Jeanne d'Arc". Logo depois, na ópera de Peguy, ascendia a símbolo do misticismo no seu ciclo de três dramas 'Le mistére de la charité de Jeanne d'Arc", J. B. Shaw verá em Joana a pura expressão daquela "elementariedade vi-

"Jeanne d'Arc au bucher" de Claudel $e$ Honneger

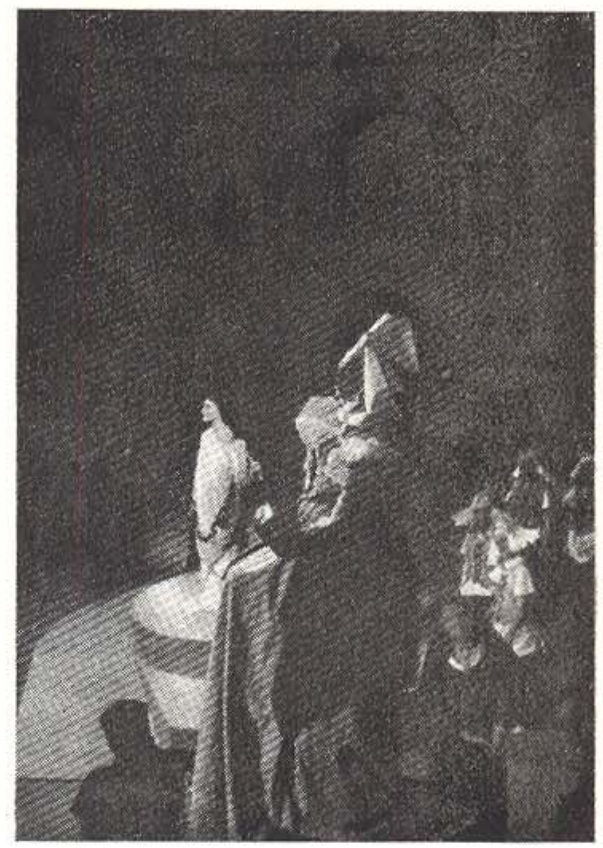




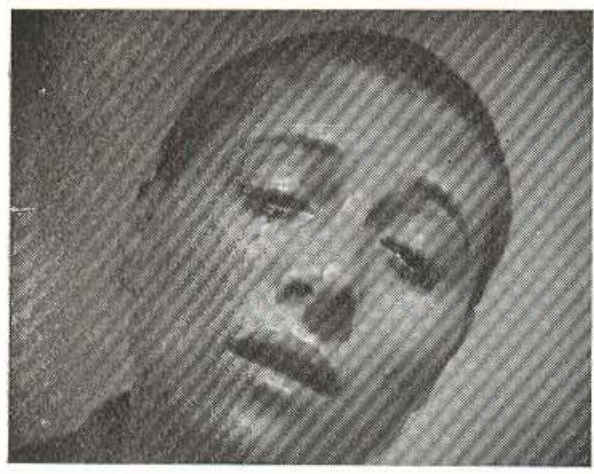

Falconetti como Joana d'Arc no filme de Dreier

tal" que vai direto às suas finalidades, superando os compromissos e a estrutura da sociedade civil. De vez em quando músicos, artistas, homens de teatro, revendo o argumento, talvez pensem ter escrito e cantado definitivamente esta jóvem que teve a fôrça de vencer seus próprios temores, que soube impor a sua fé contra cada relutância, contra cada fadiga. Encontramos assim, entre inumeráveis outros, os nomes dos músicos Hartog, Max Bruch, Peter Tchaikowsky, Moszkowsky, Marco Eurico Bossi, etc.

Honneger e Claudel compôem um notável oratório "Jeanne d'Arc au bucher" que será apresentado em todo mundo, e que foi transposto cinematográficamente por Roberto Rosselini. Ingrid Bergmann, que é a intérprete do filme, representou também o papel da heroina de Donremi num filme americano. No terreno da cinematografia a fita de Dreier marcou uma etapa fascinante da história do cinema com o vulto inesquecivel de Falconetti. Entre os nomes das artistas que interpretaram Joana d'Arc lembramos ainda, além de Sarah Bernhardt, Elisabeth Bergner, Ludmilla Pitoef, e hoje Lila Brignone, Suzanne Flon, e entre nós, Maria della Costa, que a interpretará brevemente. Ainda escreveram dramas, além do já citado Anouilh, Tierry du Maulnier e Maxwel Anderson. Concluiremos êste rápido relato, onde só uma parte dos nomes foi citada, lembrando as estátuas de Joana D'Arc que foram erigidas na Catedral de Reims e na Praca das Piramides em Paris; os afrescos de Leneveu no Panthéon de Paris, o grande quadro de Ingres e o de Scherrer. Assinalamos ainda o Museu que Orleans dedicou à sua heronina. GIANNI RATO.

\section{Barrault no Museu}

Jean Louis Barrault inaugurou o novo Departamento de Teatro do Museu, com uma palestra, no salão da pinacoteca. Louvou a iniciativa e salientou a importância do homem no teatro, como meio e fim de tôdas as atividades cenicas. Falando de improviso, discorreu também sbre a necessidade de emprendimentos desta natureza que concorrem para elevar o nível da arte do espetáculo.

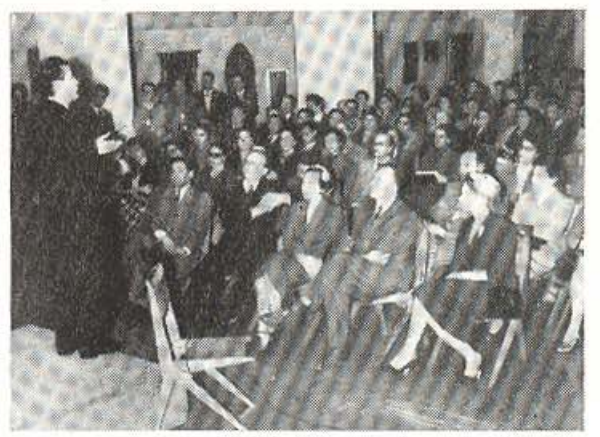

Também Pierre Bertin falou no $\mathrm{Mu}$ seu. O seu tema foi a "História da Maquillage". Maria Della Costa é Sergio Cardoso deram uma demonstraçâo prática da maquillage.

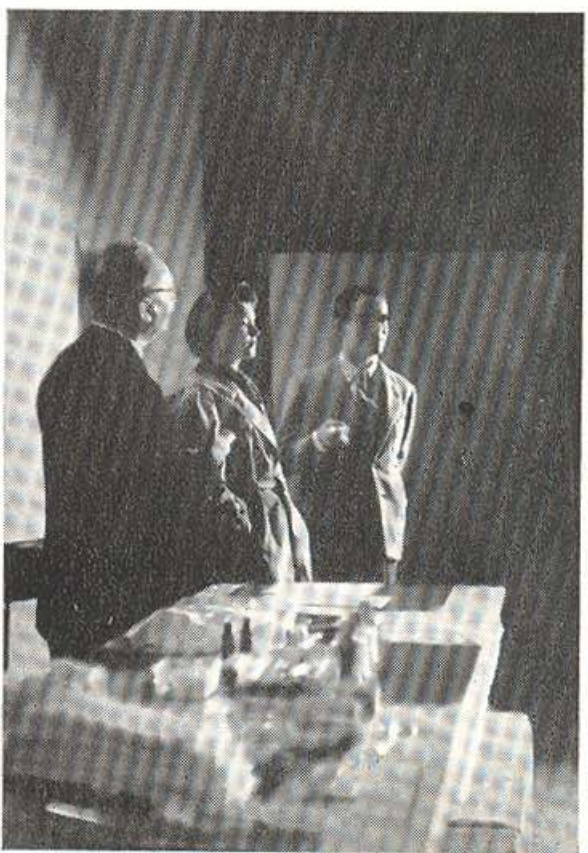




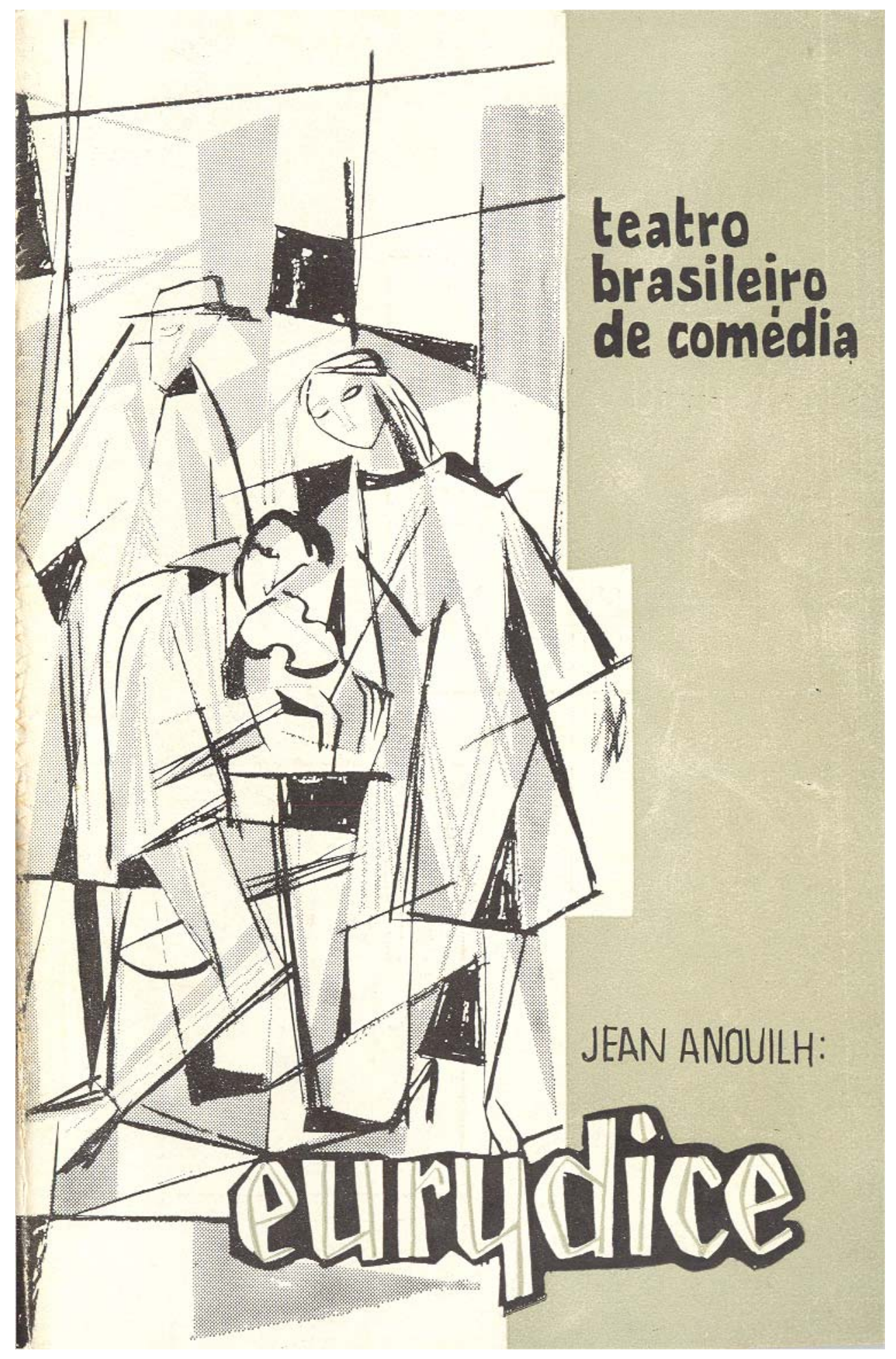




\section{TEATRO BRASILEIRO DE COMÉDIA \\ S. PAULO SOCIEDADE BRASILEIRA DE COMEDIA RIO 8.? ANO}

Diretor-Fundador Superintendente FRANCO ZAMPARI

Presidente de Honra

Francisco Matarazzo Sobrinho

Presidente

Paulo Assumpção

Vice-Presidento

Adolpho Rheingantz

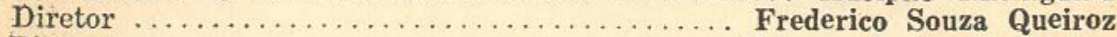

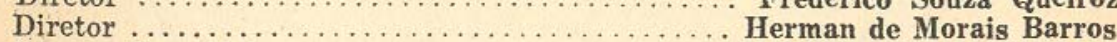

Diretor Secretário ................... $\mathbf{A b i l i o}$ Pereira de Almeida

Diretores Juridicos :

Benedito J. Soares de Mello Pati - José Luis Soares de Mello Pati Antônio Caio da Silva Ramos Jr.

\section{Diretores Artisticos \\ ZIEMBINSKI * MAURICE VANEAU * GIANNI RATTO}

Elenco Permanente :

Sras. Cacilda Becker - Carminha Brandão - Célia Biar - Cleyde Yáconis - Dina Lisboa - Elizabeth Henreid - Fernanda Montenegro Nathalia Timberg

Srs. : Elisio de Albuquerque - Eugênio Kusnet - Fermando Tôrres - Fredi Kleemann - Fregolente - Italo Rossi - Jorge Chaia - Leonardo Vilar - Luiz Linhares - Mauro Mendonca - Milton Moraes - Oscar Felipe - Sérgio Brito - Walmor Chagas - Ziembinski.

Tesoureiro $\ldots \ldots \ldots \ldots \ldots \ldots \ldots \ldots \ldots \ldots \ldots \ldots \ldots \ldots \ldots \ldots \ldots \ldots \ldots$ Guilherme Vitale Gerente Geral ............................ Ary Prado Marcondes Administrador (Rio) ......................... Cid Leite da Silva

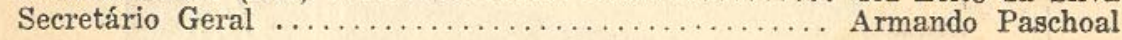

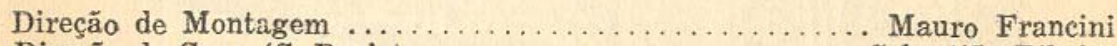
Direção de Cena (S. Paulo) …................... Sebastião Ribeiro Direção de Cena (Rio) ......................... Pedro Petersen Maquinista Chefe $\ldots \ldots \ldots \ldots \ldots \ldots \ldots \ldots \ldots$ Arquimedes Ribeiro

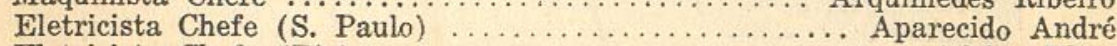
Eletricista Chefe (Rio) . ............................ Adelar Elias Maquliagem .......................... Leontij Tymosczenko

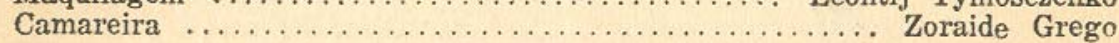

Ambiente: If Decorações 


\section{O TEATRO BRASILEIRO \\ DE COMÉDIA \\ APRESENTA}

a partir do dia 9 de Agôsto

de 1956

\section{"EURYDICE》}

$\mathrm{DE}$

JEAN ANOUILH

$\star$

TRADUÇÃO

GUILHERME DE ALMEIDA

$\star$

FIGURINOS

LUCIANA PETRUCCELLI

$\star$

CENÁRIOS E DIREÇÃO

GIANNI RATTO 


\section{NOTA SOABRE «EURIDICE»}

\section{GIANNI RATTO}

Escrever sôbre as razões de um espetáculo é, num certo sentido, antecipar uma avaliaçãa crítica, colocar em suma o carro na frente dos bois. E a coisa me incomoda um pouco, confesso.

Gosto do silencio. Se pudesse faria um teatro sem nomes, sem afiches, sem explicaçøes, apenas com um batedor que anunciasse, a golpes de tambores, que esta noite será representado «isto» cu «aquilo» e que os personagens săo de que esta noite sera representado as provincias do reino ou da república. Isto para renome e aplaudidos em todas as provincias do reino ou da república. Isto para realizou-se, solítários, no ensaio, um átı́mo de feliz perfeição.

Todavia devemos dizer, explicar: porque escolhemos êste texto quais as razões secretas se o amamos e se desejamos realiza-lo.

Acho que não existe um texto (um texto valido, é claro) que não se deixe amar quando o realizamos: é um pouco como ir de braço dado com o autor, jantar com êle, surpreender-lhe o sonc; às vezes se tem vontade de abraçá-lo, outras de dizer-lhe: deixe disso. E por fím reencontrá-lo excitados e felizes porque, querendo ou năo, êle nos conquistou dia a dia, hora a hora. Apolando-se êle em nós e pedindo-nos que nem por um minuto nem por polêmica o discutamos, ou o rejeitemos. $\mathrm{E}$ tudo com tanta graça; com tanta habilidade que não é possivel dizerlhe não:

Acho que a justificativa do espetáculo, se ela é necessária, tem de ser procurada na confianca e nas possibilidades que o teatro oferece e emprega, no fascínio que o TEATRO exerce em mim, mais do que no texto que realizo.

$$
* * *
$$

A coincidência do mito de Anouilh com o antigo é mais secreta do que aparente. A identificação tem que sêr feita, parece-me, mais nas linhas complementares do que na línha geral. O têma básico da fábula é aqui transferido sôbre um eví. dente plano moral. O desespêro do antigo Orfeu eleva-se aqui a expoente da humanidade, embóra por um curioso sentido de sobrevivência, esta humanidade tome a mão do autor sem que êle pareça repará-lo.

Algumas dessas complementares imprevistas? Quem toca a cítara (perdão, a harpa) é aqui o pai de Orfeu: se acaso o antigo Orfeu tivesse vivído teria sido destruido pela vida? Ou, quem sabe năo existirá no autor; um certo prazer sádico de destruir os antigos idolos? O Orfeu da lenda foi estraçalhado pelas bacantes: o de hoje (o pai ou o filho?) é dilacerado antes e salvo depois pela dialética envolvento da vida e de quem por ela fala: o inflexível Plutão comoveu-se duas vêzes? Mas o mito continua porque o pai continuará vivendo. Feliz? Acomodado? Preciso tomar culdado: estou correndo o perigo de polêmicas com o autor.

E Euridice? A Euridice da mitologia é quase um pretexto à lenda mesma: na peça é a razăo da tese. Por que morre Euridice? por que foge? talvez por não querer ver descoberto aquilo que ela repudia? ou porque (e parece-me a razão autên. tica) não tenha tido suficiente confiança num amor que poderia ter salvo tudo? Ela tem mêdo, é verdade, mas o seu mêdo é patetico. um mêdo dos dias que não poderão deixar de chegar e que nada pcderá salvar. Só ela pensa isso ou também nós ensamos? E se-o pensamos porque continuamos a viver?

Outras complementares? Aristeu como Dulac ou como Mathias: uma vingança póstuma. A abstração de um ponto de baldeaçấo como êste café de estação de pro. vincia: o inferno năo está aos nossos pés constantemente e os vasios caminhos que cada um de nós escolhe, ou é obrigado a escolher, não nos conduzirão talvez, sempre, ao único ponto de conjunção que é a morte? Mas se, antes ou depois, a esta pre, lő̃o conclusão chega-mos, para que entâ, anteciparia caminhe ao nosso lado?

E inevitável entrar em polémíca com o autor. Todavia, por dever de educaçăo, deixamos a êle a palavra e em condições de tudo dizer; favorecemo-lo na sua exposição.

***

o espetáculo? Como o texto, o tom da representação, caminha sôbre o flo de uma obstraç̃o realística. Para dizê-lo como Bontempelli num plano de quase uma is véres o tom é mais autêntico, mais cotidiano: outras se aproxima o lirismo; sempre, porém, à procura de uma coerência humana e de re. aproxima o lirismo; sempre, porém, à procura de uma coerencia forçar a mão, fupresentação que caminhe ao lado do texto sem deformá-lo sem forçar a máo, fudo um «clima».

(Continua na página 45) 


\section{NOTAS DO TEATRO EXTRANGEIRO}

TEATRO NA FRANÇA: Desde os primeiros dias deste mês estão se realizando as provas finais do Concurso Nacional de Teatro Universitário e Amador, sob o alta patrocínio do ministérió da Educação Nacional. As provas se realizam no Teatro de LAtelier, e algumas «troupes selecionadas já se apresentaram. São as seguintes as peça constantes do concurso: «La carrosse du Saint-Sacrement», de Merimée, «Les Vivants», de Henri Troyat, «Doiton le dire?», de Labiche, «Beau Sang» de Jules Roy, «Un chapeau de paille d'Italie», de Labiche. A troupe dos «Jeux Neufs» de Paris que ganhou o concurso do ano passado, representará «Cesar», de Pagnol.

VERSALHES - Segundo os cálculos, a reabertura da ópera Real de Versialhes será a 12 de Outubro dêste ano. As obras de restauração do grandioso palácio de arte, que foi iniciado pelo arquiteto Gabriel, em 1750, no reinado de Luiz XV, e nterrompido durante vários anos para sómente ser inaugurado em 1770 , estão sendo aceleradas. A reabertura se dará possivelmente com «Psyché», comédia-ballet em 5 atos; de Molière, escrita em versos livros com a colaboração de Corneille e música de Lulli. Tomará parte na representação dramática a troupe da «Comedie-Française» e Corpo de Baile da Opera de Paris.

JEAN VILLAR: com seu teatro Nacional Popular, de Paris, levuu recentemente em Haia, «L'Avare», de Molière. A representação foi saudada pelos aplausos tumultuosos dos espectadores e a soirée terminou $\mathrm{em}$ verdadeira batalha de flôres entre os artistas e o público. Durainte mais de uma hora, já terminado o espetáculo, os artistas tiveram que permanecer no palco e, depois, entre os assistentes, na plateia alvo de homenagens.

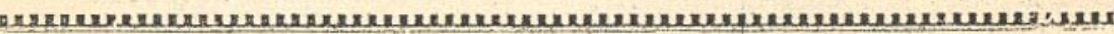

\section{(Conclusão da página 9)}

Mas repito preciso não me antecipar. Desejaria que o espetáculo chegasse : platéia, e fôsse, aceito ou não, julgado sem que eu tenha, embóra sem querê-lo, forçado a mão. Quereria que fôsse como o dialogo entre duas pessoas que se co nhecem bem há muito tempo, e às quais um olhar é suficiente para se compreender.

$$
* * *
$$

Ja faz quinze anos desde o dia no qual o autor escreveu éste texto. Muitas das razöes que justificavam a sua dialética perderam a razão de sêr.

A esperança renasceu, o instinto de conservaçáo retomou a sua medida exata. Se abrirmos os olhos e olharmos em tôrno descobriremos que a vida; no fim das contas é digna de ser vivida, mesmo que seja apenas pelos poucos momentos do poesia puríssima que ela sabe nos oferecer, e um pouco também pelo prazer qut o malabarismo dela nos proporciona diảriamente.

Queremos aceitar o que o autor nos oferece assim como se fôsse um jógu requintado e comovido para se fazer a meia-noite com máscaras ingênuas e macabras e com luzes oscilantes?

$$
\Rightarrow *
$$

So quiséssemos ser um pouco maliciosos poderiamos perguntar a Jean Anouilh se no dia do casamento de sua filha as palavras que $M$. Henry pronuncia no fim do primeiro ato não se mudaram nas seguintes: «um belo rapaz, uma bela moça e prontos a se bater até clarear o dia e a surgir intactos juntos».

s necessárlo acreditar mesmo que seja para ter, depois, a fôrça de saber suportar e aceitar as desilusőes, o desespếro. 


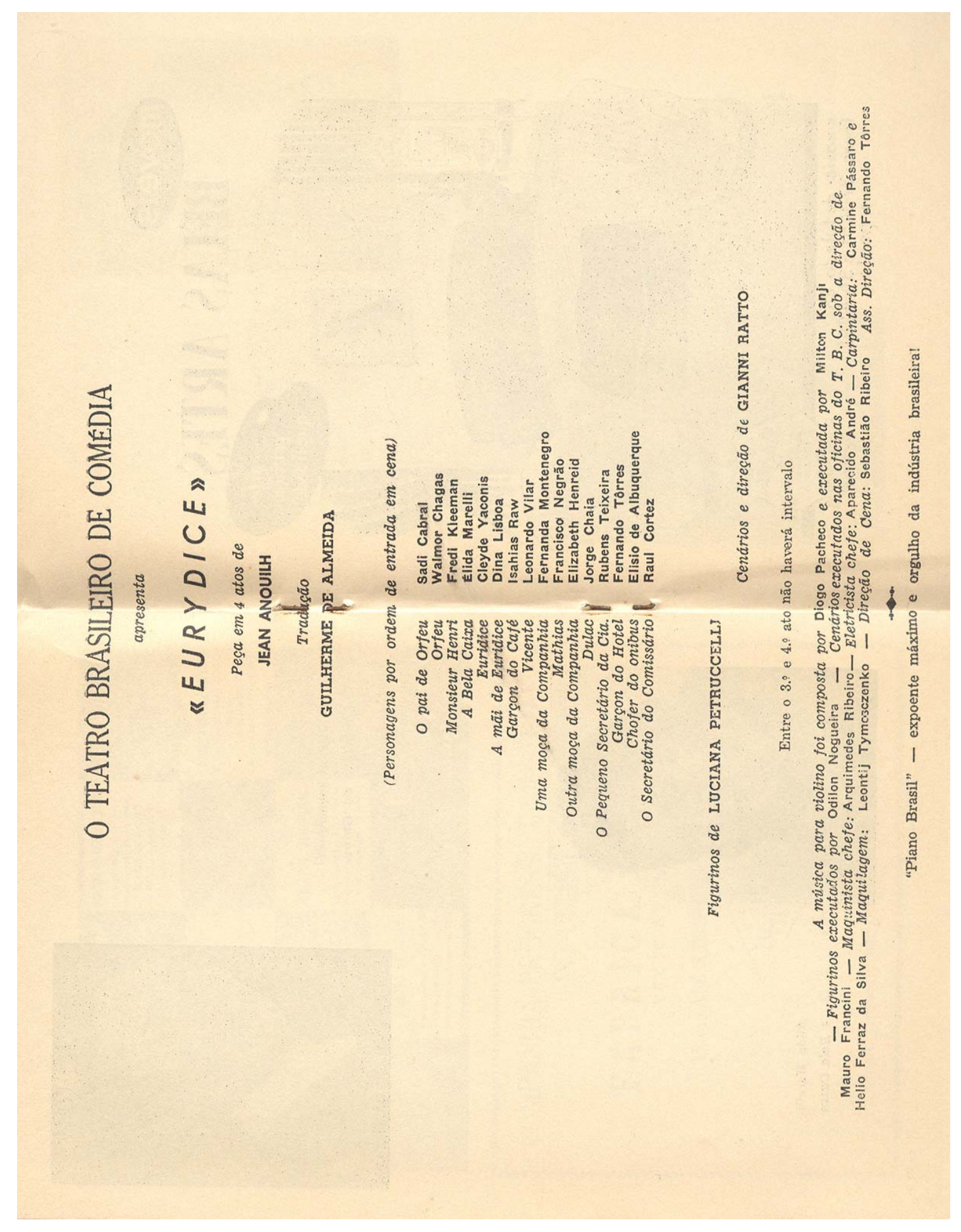




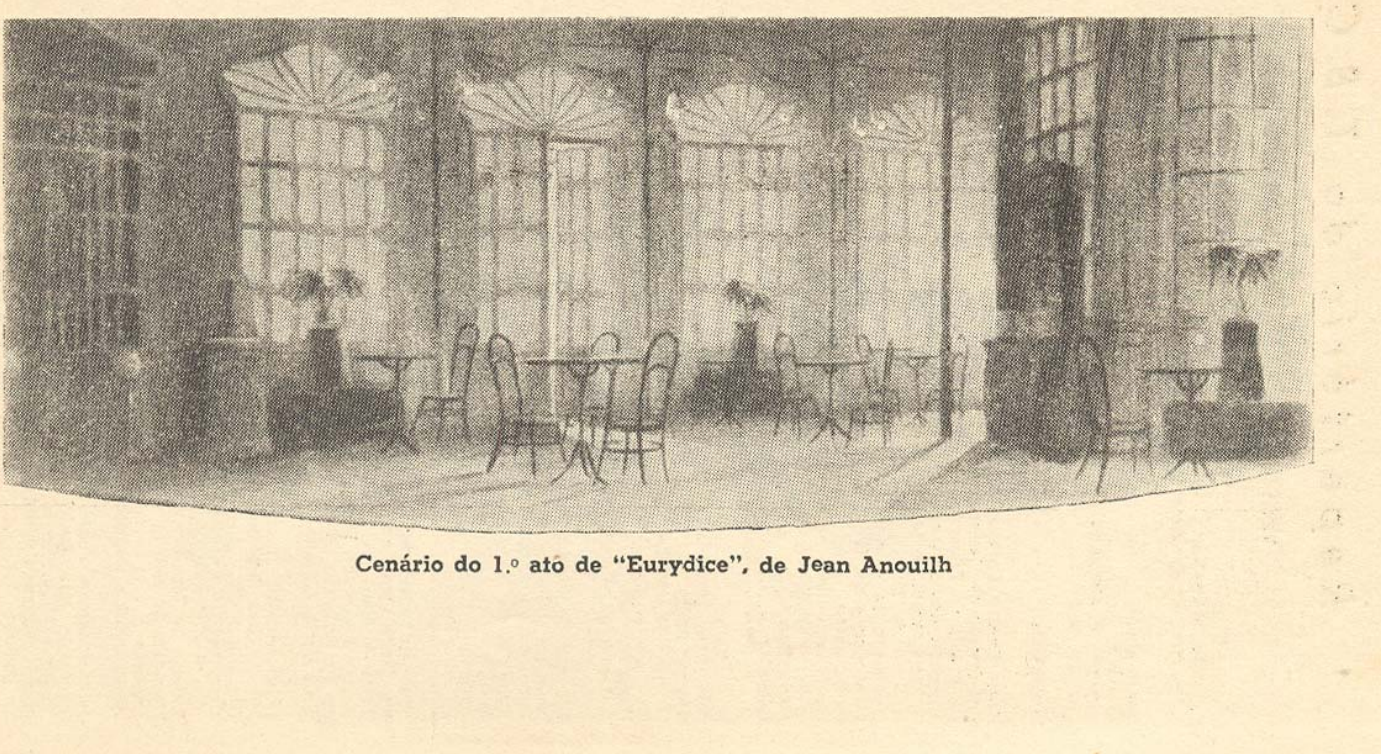


